Historic, Archive Document

Do not assume content reflects current scientific knowledge, policies, or practices. 



\section{To Our Correspondents}

$\mathbf{N}$ EARLY sixty years ago, when we began the seed business, we realized, as few seedsmen did then that the foundation of all successful crops depended largely on good seed. We determined that we would sell only the "BEST," and began breeding selected strains, urging upon all farmers and market gardeners that there was no economy in buying seed of unknown purity and germination. Since then others have come to see our viewpoint, and at the present time every State, through its Agricultural Department, is advising farmers to BUY ONLY THE BEST SEEDS. Today our "THOROBRED SEEDS" are known world-wide, and thousands of the most successful farmers, home and market gardeners pronounce them "THE BEST BY EVERY TEST."

A thorough system of testing is applied to our seeds to ascertain their vitality and vigor, and our customers are protected as far as possible against any uncertainty of germination, but with all the care a seedsman can exercise, to a certain extent, he is at the mercy of his growers; so, in common with all members of the American Seed Trade Association, we do not guarantee seeds as to description, quality, productiveness, or any other matter, and will not be responsible for the crop. Our catalog aims to tell the simple truth, and while issued primarily to promote the sale of seeds, it is not less concerned with maintaining our reputation for sincerity. Any gardener with our catalog beside him, in the matter of information concerning seeds, stands on the same footing as the truckers of the world-famous market gardening section surrounding Norfolk.

We Deliver Free by Mail, Express or Freight_- Our Option - All vegetable and flower seed orders when cash is sent at prices in this catalogue, except where noted.

We Guarantee the Safe Arrival of every package of seed we send by mail or express, but seeds shipped by ordinary freight, after taking receipt for them in good order from railroad or steamboat lines, travel at the purchaser's risk. If a package fails to arrive within a reasonable time, we should be advised.

We Make Prompt Shipments Our business is so well systematized that we can usually make shipment the same day the order is receiver.

We Cheerfully Make Corrections whenever notified of mistakes. It is our desire to be infactory to our customers. Never return seeds before communicating with us.

How to Send Money Remittance should be marle by Check, Draft or Money Order. If you live on a Rural Mail Route, just give the letter and the money to the mailcarrier and he will get the money order at the postoffice and mail it in the letter for you. Stamps can be readily utilized by us (we prefer five or ten cent stamps), and will be accepted in payment of small orders at sender's risk.

C. O. D. Shipments only made when the purchaser sends cash for one-fourth the value of the order as a guarantee of good faith.

Packing Charges The only packing charge is for bags, and these are charged at cost, or less than cost, and are not returnable.

Non-Warranty Geo. Tait \& Sons, Inc., gives no warranty, express or implied, as to description, quality, productiveness, or any other matter of any seeds, bulbs or plants it sells, and will not be responsible for the crop.

The words Thoroughbred Seeds being a registered trade-mark (U. S. Patent Office, No. 51052 ), and the word Thoroughbred being also a registered trade-mark (U. S. Patent Office, No. 92011), all persons are warned against their use in connection with the advertising or sale of seeds. We solicit the help of our friends in the detection and punishment of infringements of our copyright.

All Prices in This Catalogue Are Subject to Change Without Notice.

\section{Geo. Tait \& Sons, Norfolk, Va. Incorporated.}




\section{Hints for the Garden}

How to Sow Seeds There is no more prolific source of disappointment and failure among amateur gardeners than hasty, careless or improper sowing of the seed. A seed consists of a mirute plant enclosed in a hard and more or less impervious shell, with a sufficient amount of food stowed in or around the germ to sustain it until it can expand its leaves, form roots and provide for itself. Moisture, heat and a certain amount of air are necessary to secure germination. The germinating seed first absorbs water and swells. The starchy matters gradually become soluble. The seed-coats are ruptured, the rootlet emerges to go downward and the stemlet starts upward. The embryo lives for a time on the stored food, but gradually the plantlet secures a foothold in the soil and gathers food for itself. Germination is complete when the plantlet is able to shift for itself.

In sowing seeds it should be remembered that those sown too early are apt to produce not only an inferior crop, but often a later crop than if put in the ground at the proper time. The suggestions given in this catalogue as to the time for sowing are a safe guide, but judgment must, of course, be exercised, seasons varying greatly in different years. Remember that, as a rule, seeds do one of two things shortly after planting - they germinate and grow, or else they die. In general, seeds should be covered according to their size, the character and condition of the soil, and with due regard to the advance of the season. Rolling, or some substitute for that process of firming the soil over the seeds, greatly facilitates the germination of almost all kinds of seeds, especially in dry weather.

The Situation As success in gardening is, to a considerable degree, dependent upon the eligibility of the location, it is worth while to select the best drained and most favorable spot at command. The morning sun, which is most desirable, should, if possible, reach all parts of the place selected, and the near presence of large trees should be avoided.

The Soil A rich, sandy loam soil, which is not apt to bake into a hard crust after heavy rains, will be found best, but a fair degree of success may be secured from any soil which can be made rich and friable. The soil should be thoroughly plowed or dug to a good depth, and the surface made smooth as possible with a rake or harrow. Much of the success of a garden depends upon the proper preparation of the soil by a liberal use of stable manure or by working in vegetable matter of any kind.

Fertilizers Stable manure is the best fertilizer, and must be freely used, but should be thoroughly rotted. Liquid manure is also of great value, the famous gardeners of the East using Fertilizer almost exclusively in that form. When not possible to obtain stable manure, bone meal or pulverized sheep manure are the next best substitutes. See index for fertilizers.

Transplanting Transplanting should be done, if possible, late in the afternoon, and care should be exercised in lifting the plants to avoid injury to their tiny roots, as success depends largely upon the first step. Make the hole with a dibble, insert the root, pour a little water about it, and press the earth carefully, but firmly, around the stalk. Shade for a day or two if the weather be hot.

Cultivation Not only should every weed be removed as soon as it appears, but the crust which forms after a rain should be broken up and the ground stirred as soon as it is dry enough to permit it. The more frequently and deeply the soil is stirred while the plants are young, the better, but as they develop and the roots occupy the ground, cultivation should be shallower until it becomes a mere stirring of the surface. A small garden, well cultivated and cared for, will give larger returns than a large one poorly prepared and neglected.

\section{Spraying and Sprayers} find insecticides, sprayers and dusters on page 93, and a splendid spraying schedule on the inside back cover.
Since plant diseases have become so prevalent as to make spraying almost necessary to the perfecting of many crops, our customers will 


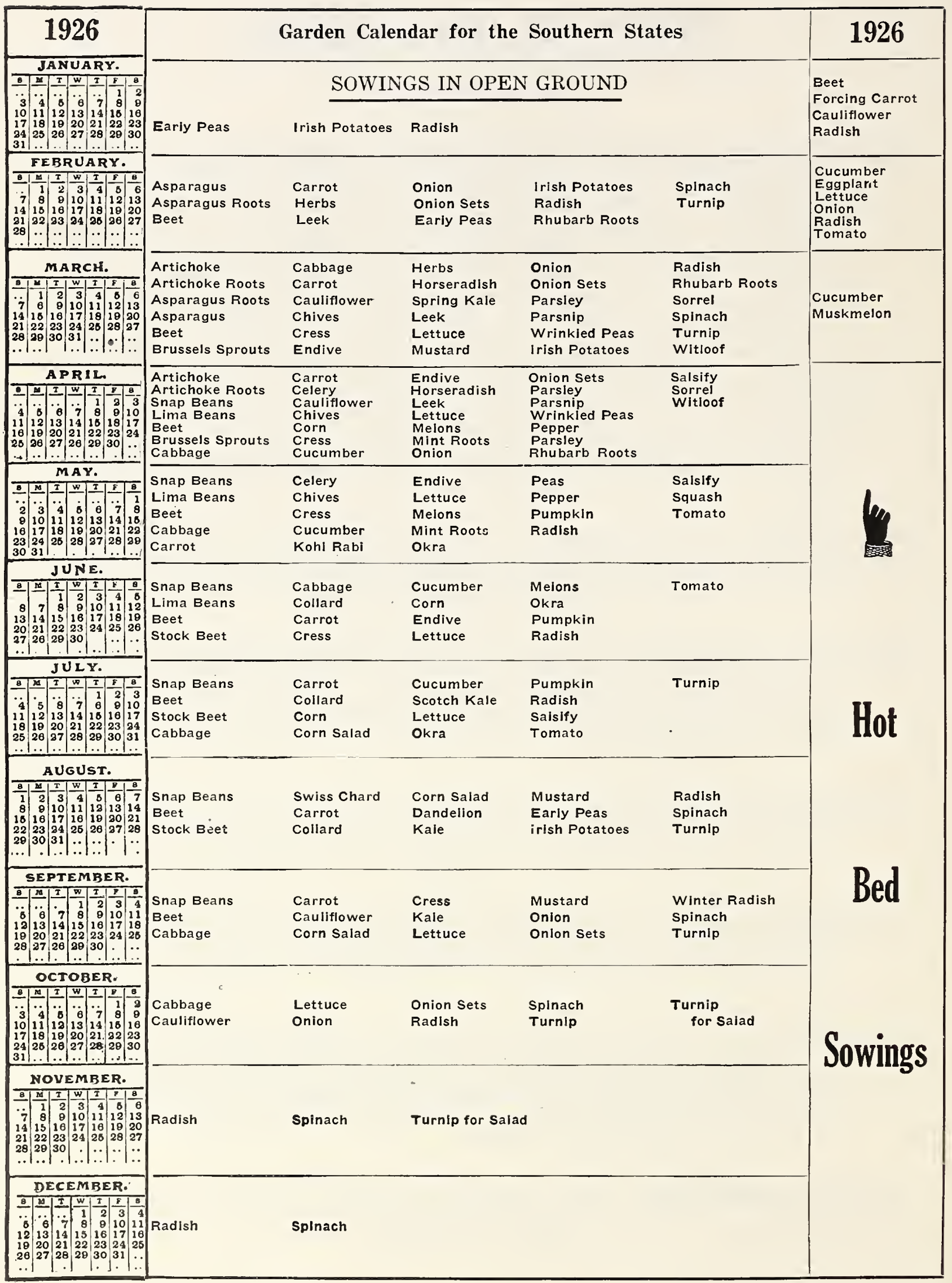




\section{A Guide to Sowing and Planting in the Southern States}

For fuller instructions, see cultural directions at the beginning of the description of each vegetable Copyright, 1914 (all rights reserved), by Geo. Tait \& Sons, Inc., Norfolk, Va.

\begin{tabular}{|c|c|c|c|c|c|c|c|c|c|}
\hline \multirow[b]{2}{*}{ VARIETY } & \multirow{2}{*}{$\begin{array}{c}\text { FOR } \\
100 \text { FEET } \\
\text { (Garden } \\
\text { Culture) }\end{array}$} & \multirow[b]{2}{*}{$\begin{array}{c}\text { FOR ONE } \\
\text { ACRE } \\
\text { (Field Culture) }\end{array}$} & \multirow{2}{*}{$\begin{array}{l}\text { TIME FOR } \\
\text { SOWING IN } \\
\text { TIDEWWATER } \\
\text { VIRGINIA }\end{array}$} & \multirow[b]{2}{*}{$\begin{array}{l}\text { DEPTH } \\
\text { TO } \\
\text { PLANT }\end{array}$} & & FIELD & CULTURE & GARDE & N CULTURE \\
\hline & & & & & $\begin{array}{l}\text { MATURITY } \\
\text { OF CROP }\end{array}$ & $\begin{array}{l}\text { Rows } \\
\text { Apart }\end{array}$ & $\begin{array}{l}\text { Plants in } \\
\text { Row }\end{array}$ & $\begin{array}{l}\text { Rows } \\
\text { Apart }\end{array}$ & $\begin{array}{l}\text { Plants in } \\
\text { Row }\end{array}$ \\
\hline Artichoke, Globe.: & $1 \frac{1}{2}$ ounces & 1 pound-T. & March. & 1 inch. & Second Spring & 3 feet. & 3 feet. & 3 feet. & $2 \frac{1}{2}$ feet \\
\hline Ar tichoke, Jerusalem Roots & 3 pounds.. & 2 to 3 bushels. & March or April. & 3 inches. & 6 to 8 months.. & 3 feet & $1 \frac{1}{2}$ feet & 3 feet. & $1 \frac{1}{2}$ feet \\
\hline Asparagus Seed & $1 \frac{1}{2}$ ounces.... & 6 to 8 pounds. & Feb. or March. & 1 inch & Third Spring .- & $1 \frac{1}{2}$ feet & 3 inches. & 1 foot. .... & 3 inches \\
\hline Asparagus Roots. & 50 & 5,000 to 7.000 & Spring or Fall & 6 to $12 \mathrm{in}$. & Second Spring & 4 feet. & $1 \frac{1}{2}$ feet. & 2 feet & $1 \frac{1}{2}$ feet \\
\hline Beans, Snap Bush..... & 1 pint... & 1 to $1 \frac{1}{2}$ bush & April to Aug....... & $1 \frac{1}{3}$ inches & 60 to 75 days. & $2 \frac{1}{2}$ feet. & 4 to 6 inc & 2 feet..... & 6 inches \\
\hline Beans, Snap Pole & $\frac{1}{2}$ pint (in hills) & 8 to 12 quarts. & April to July & $1 \frac{1}{3}$ inches & 75 to 100 days & 4 feet... & 4 feet. & 4 feet & 4 feet \\
\hline Beans, Lima Bush, Large & 1 pint & $1 \frac{1}{2}$ bushels & May to July...... & 1 inches & 75 to 100 days & 3 feet. & 15 to 18 inches & 3 feet & $1 \frac{1}{2}$ feet \\
\hline Beans, Lima Bush, Small & 1 pint. & $\frac{3}{4}$ bushel.... & May to July................. & $1 \frac{1}{3}$ inches & 70 to 90 days. & $2 \frac{1}{2}$ feet. & 10 to 12 & $2 \frac{1}{2}$ feet & 12 inches \\
\hline Beans, Lima Pole, Large & 1 pint (in hills) & $\frac{3}{4}$ bushel. & May to July & $1 \frac{1}{2}$ inches & 90 to 100 days & 4 feet... & 4 feet. & 4 feet & 4 feet \\
\hline Beans, Lima Pole, Small & $\frac{1}{2}$ pint (in hills) & $\frac{1}{4}$ bushel & May to July & $1 \frac{i}{2}$ inches & 90 to 100 days & 4 feet. & 4 feet. & 4 feet & 4 feet \\
\hline Beets & 2 ounces............ & 4 to 10 lbs. - . & Feb. to Aug........... & $\frac{3}{4}$ inch. & 90 to 100 days & $1 \frac{1}{3}$ feet. & 4 to 6 in & 1 foot... & 4 to 6 inches \\
\hline Beets (Swiss Chard). & 2 ounces & 6 to 8 pounds. & Feb. to August... & $\frac{3}{4}$ inch & 75 to 90 days & $1 \frac{i}{2}$ feet & 10 to 12 inches & $1 \frac{1}{2}$ feet & 10 to $12 \mathrm{in.}$ \\
\hline Beets (Ma & 2 ounces. & 6 to 8 pounds. & April to July & inch & 4 to 6 months & $2 \frac{1}{2}$ feet & $10 \mathrm{il}$ & 2 feet & 10 inches \\
\hline Borage.... & 1 ounce.... & $1 \frac{1}{2}$ pounds.... & March and April & $\frac{1}{2}$ inch & 60 to 90 days.. & $1 \frac{1}{2}$ feet & ches & $1 \frac{1}{2}$ feet... & 10 to 12 in. \\
\hline Broccoli & 1 ounce..... & $\frac{1}{4}$ pound $-T$. & April to Nov.... & $\frac{1}{2}$ inch & 3 to 4 months. & $2 \frac{1}{2}$ feet & $2 \frac{1}{2}$ feet. & $2 \frac{1}{2}$ feet... & $2 \frac{1}{2}$ feet \\
\hline Brussels Sprouts. & 1 ounce.. & $\frac{1}{4}$ pound $-\mathrm{T}$. & April or Sept...... & inch. & 4 to 6 months. & $2 \frac{1}{2}$ feet & $2 \frac{1}{2} \mathrm{fec}$ & $2 \frac{1}{2}$ eet. & $2 \frac{1}{2}$ feet \\
\hline Burnet. & 1 ounce... & 2 to 5 pounds. & April and Aug. & inch.... & 60 to 75 days.. & $1 \frac{1}{2}$ feet. & 10 inches. & $1 \frac{1}{2}$ feet. & 10 inches \\
\hline Cat & 1 ounce... & $\frac{1}{2}$ pound-T. & Sept. to Dec.... & $\frac{1}{4}$ inch & May and June & $2 \frac{1}{2}$ feet & $15 \mathrm{in}$ & $2 \frac{1}{2}$ feet & 15 \\
\hline $\mathrm{Cab}$ & 1 ounce. & $\frac{1}{2}$ pound $-T$ & March to May. & inch & 3 to 4 months & 3 feet & $1 \frac{1}{3}$ feet & $2 \frac{1}{2}$ feet. & $1 \frac{1}{2}$ feet \\
\hline Cabbage (Winter) & 1 ounce. & $\frac{1}{2}$ pound-T. & May to August...- & $\frac{1}{4}$ inch........... & 3 to 4 months.- & 3 feet. & $1 \frac{1}{2}$ feet & $2 \frac{1}{2}$ feet. & $1 \frac{1}{2}$ feet \\
\hline $\begin{array}{l}\text { Cantaloupe (See Musk- } \\
\text { melon). }\end{array}$ & & & & & & & & & \\
\hline Car & 1 ounce....... & $\frac{1}{2}$ pound-T. & March and April & $\frac{1}{4}$ inch. & 3 to 4 months.. & $2 \frac{1}{2}$ feet & $1 \frac{1}{2} \mathrm{f}$ & $2 \frac{1}{2}$ feet. & $1 \frac{1}{2}$ \\
\hline Car & 1 ounce..... & 2 to 5 lbs. - B. & March to August & $\frac{1}{2}$ inch. & 75 to 100 days & $1 \frac{1}{2}$ feet & $4 \mathrm{in}$ & $1_{2}^{1}$ feet & 4 in \\
\hline flower. & 1 ounce-_--- & $\frac{1}{4}$ pound $-\mathrm{T}$ & April to Nov....... & inch. & 3 to 5 months.- & $2 \frac{1}{2}$ feet & $1 \frac{1}{2} \mathrm{fee}$ & $2 \frac{1}{\text { feet }}$ & $1 \frac{1}{2} \mathrm{f}$ \\
\hline Cel & 1 ounce._._. & $\frac{1}{4}$ pound $-\mathrm{T}$. & April and May.... & $\frac{1}{8}$ inch. & 3 to 4 months.. & $1 \frac{\pi}{2}$ feet. & 6 to & $1 \frac{1}{3}$ feet. & nches \\
\hline $\begin{array}{l}\text { Celery } \\
\text { Chervil }\end{array}$ & 1 ounce._-_. & $\frac{1}{k}$ pound $-T$ & April to July ..... & inch & 4 to 6 months. & 4 feet & $6 \mathrm{tc}$ & $2 \frac{1}{2}$ feet... & hehes \\
\hline $\begin{array}{l}\text { Chervil } \\
\text { Chicory }\end{array}$ & 1 ollnce...... & 3 to 5 pounds. & April and May .... & inch. & 60 to 75 days. & $1 \frac{1}{2}$ feet & 6 inc & $1 \mathrm{foot}$. & $6 \mathrm{it}$ \\
\hline Chis & 1 ounce & 3 to 5 pounds. & April to July....... & $\frac{1}{2}$ inch. & 3 to 4 months.. & $1 \frac{1}{2}$ feet & & 1 foot. & $6 \mathrm{i}$ \\
\hline Seed. & 1 ounce.- & 4 to 6 lbs.-T B.. & March and Sept. & $\frac{1}{2}$ inch. & 3 months......... & $1 \frac{1}{2}$ feet. & & 1 foot... & \\
\hline Chives Sets. & 1 doz. clumps.- & 300 clumps...... & March and Oct... & 1 inch. & 60 days.... & $1 \frac{1}{2}$ feet & $3 i$ & 1 foot.... & \\
\hline $\begin{array}{l}\text { Collards } \\
\text { Corn }\end{array}$ & 1 ounce & $\frac{1}{2}$ pound $-\mathbf{T}$ & March to July... & $\frac{1}{4}$ inch. & 3 to 4 months. & 3 feet & $3 \mathrm{fee}$ & 3 feet & \\
\hline Corn & $\frac{1}{2}$ pint (in hills) & 6 to 10 quarts. & April to July........ & 1 inch. & 60 to 110 days & 3 feet & $1 \frac{1}{2}$ feet. & 3 feet & $1 \frac{1}{2}$ \\
\hline Salad. & 2 ounces.............. & 3 to 5 pounds. & A pril to Sept..... & $\frac{1}{2}$ inch & 60 days............... & $1 \frac{1}{3}$ feet & 10 inche & $1 \frac{1}{2}$ feet & $10 \mathrm{i}$ \\
\hline Cress, Garden & 1 ounce......... & $1 \frac{1}{2}$ pounds.......... & March to Oct...... & $\frac{1}{8}$ inch. & 50 to 60 days.. & $\mathbf{1}_{2}^{i}$ feet. & 6 to 9 inches. & $1 \frac{1}{2}$ feet... & 6 to 9 inches \\
\hline $\begin{array}{l}\text { Cress, Water. (See Cultural) } \\
\text { Directions.) }\end{array}$ & & & & & & & & & \\
\hline 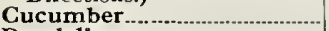 & 1 oz. (in hills). & 2 to 10 pounds & Apr & h._. & 10 days & & 12 & 4 feet $\ldots$ & $4 \mathrm{ft}$. \\
\hline Dar & 1 ounce. & 4 to 6 pounds... & d August & & 6 to & $1 \frac{1}{2}$ feet & 9 to 12 in & $1 \frac{1}{2}$ feet.- & 9 to 12 inches \\
\hline lant... & 1 ounce.... & 6 ounces - T & Feb. to May....... & in & 4 to & 4 feet & 3 feet. & 4 feet & 3 feet \\
\hline Endive.... & I ounce... & 1 pound-TB. & April to Sept.... & $\frac{1}{4}$ inch. & 3 to 4 months.. & $1 \frac{1}{2}$ feet & 9 in & $1 \mathrm{foot}$ & $9 \mathrm{i}$ \\
\hline 1, Florence & 1 ounce. & 2 to 5 pounds & April to July. & $\frac{1}{2}$ inch & 3 to 4 months. & I f feet & 8 inch & $1 \frac{1}{2}$ feet & 8 incl \\
\hline Sets & 2 to 3 pounds & 350 ibs. $-B$ & March and April & 1 inch. & 4 to 6 months. & $1 \frac{1}{2}$ feet & 4 to 6 inches.. & 1 foot... & 4 to 6 inches \\
\hline $\begin{array}{l}\text { Gherkin (See Cicumber)... } \\
\text { Horseradish Roots. }\end{array}$ & $100 \ldots$ & & 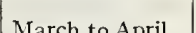 & & & & & & \\
\hline Kale (Green or Siberian). & 1 ounce....... & $1 \frac{1}{2}$ pounds... & $\begin{array}{l}\text { March to April..- } \\
\text { August to Oct..... }\end{array}$ & $\begin{array}{l}3 \text { inches.- } \\
\frac{1}{2} \text { inch.-.. }\end{array}$ & $\begin{array}{l}8 \text { months...... } \\
2 \text { to } 3 \text { months. }\end{array}$ & $\begin{array}{l}2 \frac{1}{2} \text { feet. } \\
2 \frac{1}{2} \text { feet. }\end{array}$ & $\begin{array}{l}9 \text { to } 12 \text { inches.- } \\
8 \text { to } 10 \text { inches.. }\end{array}$ & $\begin{array}{l}2 \text { feet.-- } \\
2 \frac{1}{3} \text { feet }\end{array}$ & $\begin{array}{l}12 \text { inches } \\
8 \text { to } 10 \text { inches }\end{array}$ \\
\hline Kale (Plain) & 1 ounce........... & $1 \frac{1}{2}$ pounds... & Feb. to Oct. & $\frac{2}{2}$ inch.... & 50 to 75 days & $1 \frac{1}{3}$ feet. & 6 to 8 inches.... & $1 \frac{1}{2}$ feet & 6 to 8 inches \\
\hline Kale (Scotch) & 2 ounces. & 3 to 7 pounds. & August and Sept. & $\frac{1}{2}$ inch. & $2 \frac{1}{2}$ to 4 months & $2 \frac{1}{2}$ feet. & 8 to & $1 \frac{1}{2}$ feet & $8 t$ \\
\hline Koh1 Rabi._... & 1 ounce..-_ & $1 \frac{1}{2}$ pounds & id May.... & $\frac{1}{2}$ inch... & 90 to 100 days & $1 \frac{1}{3}$ feet. & 6 to & $1 \frac{1}{2}$ feet & $6 \mathrm{t}$ \\
\hline Lee & 1 ounce...... & 4 to 6 pounds. & Feb. and March. & $\frac{1}{2}$ inch. & 6 to 8 months.. & $1 \frac{1}{3}$ feet & 4 to 6 inch & $1 \frac{1}{2}$ feet & 4 to 6 inches \\
\hline Let & 1 ounce. & $\frac{1}{2}$ pound-T B & March to Oct.... & $\frac{i}{8}$ inch. & 2 to 3 months.. & $1 \frac{1}{2}$ feet & 9 inc & 1 foot & 9 inches \\
\hline $\mathrm{Ma}$ & $1 \mathrm{oz}$. (in hills) & 2 to & Ap & $\frac{1}{2} \mathrm{i}$ & nths & $3 \mathrm{f}$ & 3 & $3 \mathrm{fer}$ & \\
\hline $\mathbf{M}$ & 50 & 10,000 & and Fall & 2 in & 5 days.. & 3 feet. & 12 & $3 \mathrm{f}$ & ches \\
\hline $\mathbf{M}$ & 1 oz. (in hills) & $1 \frac{1}{2}$ to 3 pounds & April to June..... & $\frac{1}{2}$ inch. & $2 \frac{1}{2}$ to 4 months & $6 \mathrm{fee}$ & $4 \mathrm{fec}$ & 6 feet & \\
\hline (ater) & 1 oz. for 25 hills & 2 to 3 pounds.. & April to June & $\frac{1}{2}$ inch & 3 to 4 months.. & 8 feet & $8 \mathrm{fe}$ & 8 feet & \\
\hline $\begin{array}{l}\text { Mushroom Spawn } \\
\text { Mustard.................. }\end{array}$ & 1 pounds........................... & $1 \frac{1}{2}$ pounds.. & Feb. to Oct......... & $\begin{array}{l}2 \text { inches } \\
\frac{1}{4} \text { inch. }\end{array}$ & 60 to 75 days.. & $1 \frac{1}{2}$ & 6 & $1 \mathrm{f}$ & 3 inches \\
\hline Okra & 1 ounce. & 6 to 8 pounds. & May to July....... & 1 inch. & 75 to 100 days & $\left\{\begin{array}{l}\text { Dwf } 2 \\
\text { Tali } 4\end{array}\right.$ & $1 \frac{1}{3}$ feet & $2 \mathrm{fe}$ & $\begin{array}{ll}1 \frac{1}{2} \\
3\end{array}$ \\
\hline On & 1 ounc & 4 to 6 lbs. $-\mathrm{TB}$ & Sept. and March & $\frac{1}{3}$ inch. & 4 to & $1 \pm$ feet. & 4 to 6 in & 1 foot & 4 in \\
\hline & $2 \mathrm{p}$ & $-\bar{B}$ & Spr & $1 \mathrm{i}$ & $3 t$ & $1 \frac{1}{2} \mathrm{fe}$ & 4 to & 1 foot. & $4 \mathrm{t}$ \\
\hline $\mathrm{Pa}$ & 1 ounce.... & 3 to $5 \mathrm{lbs} .-\mathrm{B}$. & Feb. to August. & $\frac{1}{4}$ inch & 3 to & $1 \frac{1}{3}$ & 6 to & 1 foot... & $6 \mathrm{t}$ \\
\hline lips... & 1 ounce..... & 4 to 6 pounds. & March to July.... & $\frac{1}{4}$ inch & 3 to 4 months.. & $1 \frac{1}{2}$ feet & & $1 \frac{1}{2}$ feet & $4 \mathrm{t}$ \\
\hline 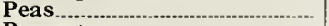 & 1 quart. & 1 to 2 bushels. & ary to June. & 2 to 3 in. & 50 to 85 days.- & $2 \frac{1}{2}$ feet & 1 to $3 \mathrm{inc}$ & $2 \frac{1}{2}$ feet & \\
\hline Pes & 1 quart & 2 bushels... & April to June........ & 1 inch. & 75 to 90 days.- & 2 to $3 \mathrm{ft}$. & 10 to $18 \mathrm{i}$ & 2 to $3 \mathrm{ft}$. & $1 t$ \\
\hline Pepper...... & 1 ounce.-. & 6 ounces $-T$. & February to June & $\frac{1}{8}$ inch. & 3 to 5 months.. & $2 \frac{1}{2}$ feet. & 12 to 18 inches & $2 \frac{1}{2}$ feet & 12 to \\
\hline Potatoes.. & 5 pounds & 4 to 5 barrels.... & $\left\{\begin{array}{l}\text { Feb. to April, } \\
\text { July and August }\end{array}\right.$ & 4 to 6 in & 3 to 4 months. & 3 feet... & 12 to 15 inches & 3 feet...- & 12 to $15 \mathrm{in}$. \\
\hline Pota & 100 plan & 10.000 plan & May to July......... & 1 to $2 \mathrm{in}$. & $3 t$ & $3 \mathrm{f}$ & 12 to 15 inche & 3 feet... & 12 \\
\hline $\mathbf{P u}$ & $1 \mathrm{oz}$. for 25 hills & 2 to & May to July..... & 1 inch. & 3 t & $8 \mathrm{fe}$ & & 8 feet. & \\
\hline & 1 ounce-_._._... & 3 to 30 lbs. - B. & Feb. to Oct. & inch._. & 1 to 3 mont hs.. & $1 \frac{1}{2}$ feet & 1 to 6 inches. & 1 foot.... & 1 to 6 inches \\
\hline Rh & 1 ounce............ & 8 to 10 lbs. $-\mathrm{T}$. & March to May & $\frac{1}{2}$ inch & Second Season & $1 \frac{1}{2}$ feet & 6 inches...... & $1 \frac{1}{2}$ feet. & $6 \mathrm{i}$ \\
\hline & & 3,000 & $\begin{array}{c}\text { March and April, } \\
\text { or Novermber }\end{array}$ & 3 to 4 in. & 2 to 5 months. & 4 feet & 4 feet. & 4 feet. & 4 feet \\
\hline & 2 ounces....... & 6 to 8 pounds. & April to July & $\frac{1}{2}$ inc & 3 to $4 \mathrm{mo}$ & $1 \frac{1}{3} \mathrm{f}$ & $3 \mathrm{tc}$ & $1 \mathrm{f}$ & $3 t$ \\
\hline & 1 ounce & 1 to $1 \frac{1}{2}$ lbs. $-\mathrm{T}$. & March and April & $\frac{1}{8}$ inch... & 75 days.. & $1 \frac{1}{2}$ feet. & 4 to 6 inches. & $1 \mathrm{fo}$ & 4 to 6 inches \\
\hline & & 15 to 30 lbs.-B. & $\begin{array}{l}\text { Feb. to April, } \\
\text { Sept. to Nov. }\end{array}$ & $\frac{x}{2}$ inch.. & $2 \frac{1}{2}$ to 4 months & $1 \frac{1}{2}$ feet & 4 to 6 inches & 1 foot.... & 4 to 6 inches \\
\hline Sq & $1 \mathrm{oz}$. (in hills). & 2 to & April to Jul & 1 inch. & 60 to 75 days. & $2 \frac{1}{2} \mathrm{fe}$ & 2 feet & $2 \frac{1}{2}$ feet & $2 \mathrm{fe}$ \\
\hline lash, Running & 1 oz. for 25 hills & 1 to 3 pounds... & April to July...... & 1 inch & 75 to 90 days & 8 feet... & 8 feet. & $6 \mathrm{feet}$ & 6 feet \\
\hline $\begin{array}{l}\text { Spring Sprouts (See Plain } \\
\text { Kale). }\end{array}$ & & & & & & & & & \\
\hline To & 1 ounce...... & 4 ounces-T. & July. & $\frac{1}{8}$ inch. & 3 to 4 montlis. & 4 feet. & 3 feet & i 4 feet. & \\
\hline & 1 ounce & $1 \frac{1}{2}$ to 3 pounds & Feb. to August & $\frac{1}{2}$ inch. & 2 to 3 months. & $1 \frac{1}{2}$ feet & 6 to 8 inc & 1 foot. & 6 to 8 inches \\
\hline row & $1 \mathrm{oz}$. for 25 hills & 1 to 3 pounds.. & April to July...... & 1 inch. & 75 to 90 days.. & 8 feet.... & 8 feet._.-. & 6 feet. & \\
\hline Chicory). & & & & & & & & & \\
\hline
\end{tabular}

$T$-Those marked $T$ are usually sown on beds and transplanted into rows.

B-Those marked $B$ are usually sown in beds from 4 to 7 feet wide, leaving 9 to 10 inches between the rows.

G-A 5 or 10-cent package of those varieties designated to be transplanted wlll be sufficient to set a row 150 feet long, when properly sown in a box or bed. 


\section{Tait's Thoroughbred Vegetable Seeds}

TOR over half a century it has been our constant endeavor to breed and sell the best seeds that I can be grown, and our customers will find listed such varieties as, from tests and the actual experience of successful gardeners, have proven of superior merit. We have priced them as low as carefully grown seeds can be sold.

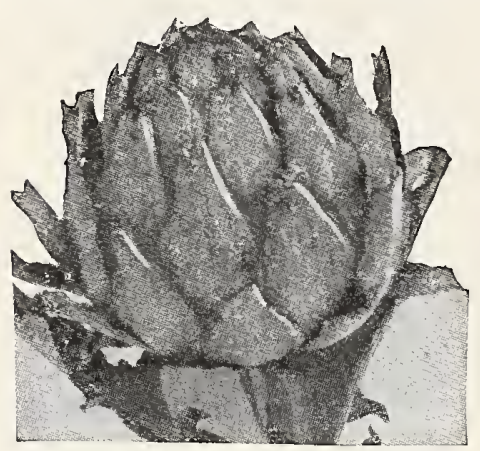

Green Globe Artichoke.
All Prices in This Catalogue Are Subject to Change Without Notice.

\section{ARTICHOKE}

(Cynara Scolymus.)

Artichaut. Artischoke. Articiocca. Alcachofa.

CULTURE.-1 ounce is enough for 75 feet of drill, and 1 pound will produce enough plants to set out an acre. Sow 1 inch deep the last of March in light, rich soil, and transplant, when large enough, into rows 3 feet apart, leaving 3 feet between the plants in the row. It is a perennial which does not come into bearing until the second season, but if properly cultivated will continue to yield for many years. As the plant will become exhausted if the heads are allowed to ripen, they must be cut even if not wanted for the table.

Green Globe. The standard sort. The flower heads while immature, are very tender Green Globe, and of peculiarly delicious flavor. Pkt. 10 cts., oz. 50 cts., 1/4 lb. $\$ 1.75$, 1b. \$6.00. Postpaid.

Artichoke Roots. Jerusalem artichokes are distinct from the Globe, and are propagated by and for the tubers. Their principle use is for feeding hogs, altho they make splendid pickles, may be eaten raw or served boiled like new potatoes. Plant in March or April 3 inches deep in rows 3 feet apart and 18 inches in the row. Treat much in the same way as Irish potatoes. Lb. 30 cts., 10 lbs. \$1.50. Postpaid.

\section{A S PA R AG U S \\ (Asparagus officinalis.) \\ Asperge. Spargel. Sparagio. Esparrago.}

CULTURE.-One ounce is sufficient for 75 feet of drill; 6 to 8 pounds to the acre. Sow in February or March in rows $1 \frac{1}{2}$ feet apart and 1 inch deep, having previously soaked the seeds 24 hours in warm water. Thin the seedlings to 3 inches in the row, reserving only the most vigorous, and keep the ground clean throughout the season. Transplant the following spring into trenches, which may be 4 or 5 feet apart, according to the space available, setting the crowns 15 to 18 inches apart, and taking care to spread the long roots as widely as practicable. To make white stalks, the trench should be about 12 inches deep, but if green shoots are preferred, 7 inches will be deep enough. An inch or two of earth is sufficient covering for the first year, the ground being levelled the second season. Every Autumn the stalks should be cut down and carefully removed in order to avoid scattering seeds over the bed, and the bed then covered with a heavy coating of manure. Early in the spring this covering should be forked in, care being taken to avoid injury to the roots; if a plow be used, the cultivation must be very shallow. Cutting may be begun in earnest after two seasons, and the bed, if well cared for, should last 10 to 12 years. Do not cut too closely or too long, as the health of the roots require some foliage during the year.

Mary Washington. An improved rust-resistant strain, becoming more popular large stalks of the best quality. Pkt. 10 cts., oz, 30 cts., $1 / 4$ lb. 90 cts, lb. $\$ 3.00$. Postpaid. Palmetto. A standard market asparagus in Virginia, the Carolinas and Florida. It almetto. is a rapid and even grower, very regular in size and keeps well. The immense stalks make a most attractive bunch. Pkt. 5 ets., oz. 10 cts., 1/4 lb. 25 cts., lb. 75 cts. Postpaid.

White Columbian. Not popular with Southern growers, because it does not reach full productiveness until the fourth year. For canthe best variety. Pkt. 5 cts., oz. 10 cts., $1 / 41$ lb. 25 cts., lb. 75 cts. Postpaid.

\section{ASPARAGUS ROOTS}

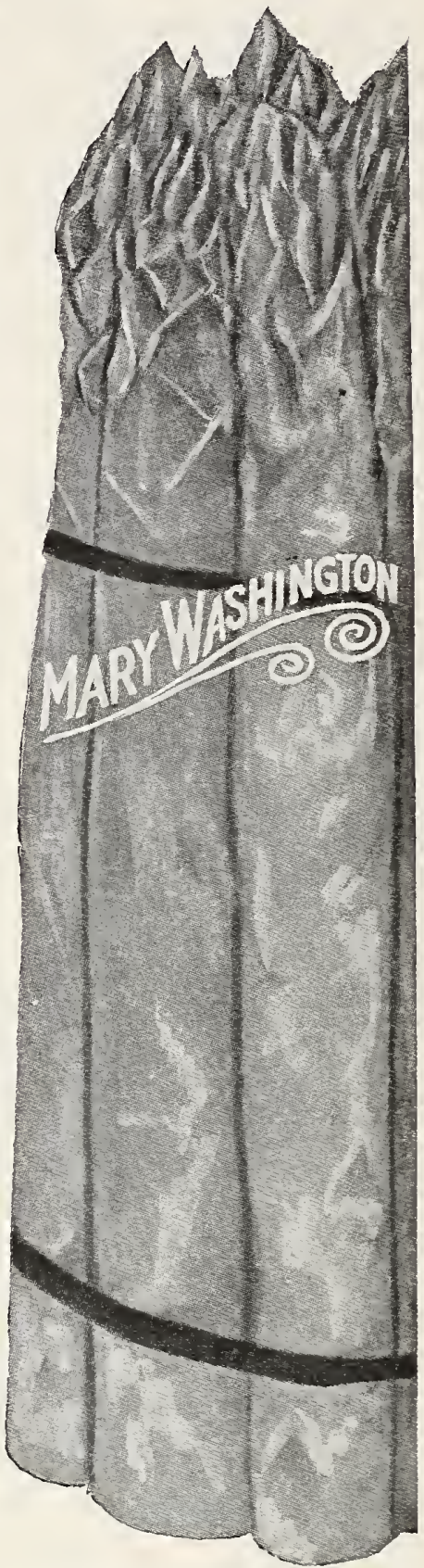

Mary Washington Asparagus.

Five thousand to seven thousand roots are required to the acre, and should be planted from seven to twelve inches deep. A family of ordinary size will find one hundred roots sufficient to keep it supplied with asparagus during the season.

Washington. (Two-year-old roots.) Palmetto. (Two-year-old roots.) White Columbian. (Two-year-old $\$ 2.75$ per 100. Postpaid. $\$ 1.75$ per 100 . Postpaid. roots.) $\$ 1.75$ per 100 . Postpaid.

Remember we deliver free at catalogue prices-except where noted. Write for special prices in large quantities. 


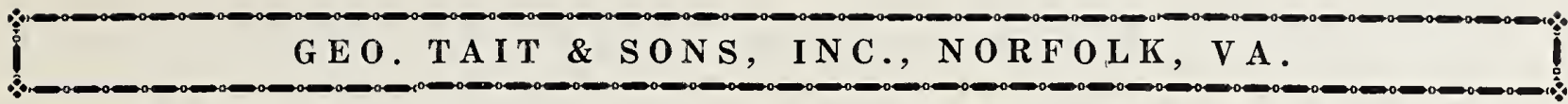

\section{BEANS, DWARF OR BUSH}

(Phaseolus Tulgaris.)

Haricot Nains. Irupp Eohnen. Faginolo-nani. Frijole Na.

Our Customers will note that we quote beans by weight instead of measure-a pound equals in measure about one pint, and a bushel weighs sixty pounds.

CULTURE-1 pint of beans will sow about 100 feet of drill, from 1 to $1 \frac{1}{2}$ bushels being allowed to the acre. While most varieties of beans, especially wax, are very tender, and should not be planted in the latitude of Norfolk before the bcginning of April, if one is disposed to take some risk, sowings may be made as early as the 17 th of March. If a succession is desired, plant at intervals of about 2 weeks until August. Prepare the ground well, manure lightly, and plant $1 \frac{1}{2}$ inches deep, in rows $2 \frac{1 / 2}{2}$ feet apart, allowing 4 to 6 inches between green kinds, and 6 to 8 between the wax. Keep well cultivated, always drawing the earth to the plants, but avoid working the ground when it is wet or when dew is on the beans, as it is apt to cause "rust."

\section{GREEN PODDED VARIETIES}

Black Valentine. This variety, sometimes called King of the account of its earliness, Eardines, continues to hold its popularity on round green pods are nearly straight, and while not stringless, are of good quality when young. A great favorite with Southern Market Gardeners, as it will withstand unfavorable weather conditions when sown early in the spring better than any other sort. Pkt. 10 cts., $1 / 2$ lb. 25 cts., 1 lb. 45 cts., 2 lbs. 80 cts., 4 lbs. $\$ 1.50,10$ lbs. $\$ 3.00$. Postpaid.

Bountiful. Whether for early market, or the home garden, this is Bountiful. the most desirable flat green-podded bean. It is extra early, hardy, an enormous bearer, and the long, handsome pods are stringless and of excellent quality, and it is growing in favor each season. Pkt. 10 cts., $1 / 2$ lb. 30 cts., 1 lb. 50 cts., 2 lbs. 90 cts., 4 lbs. $\$ 1.75$, 10 lbs. \$3.50. Postpaid. (See illustration, front cover.)

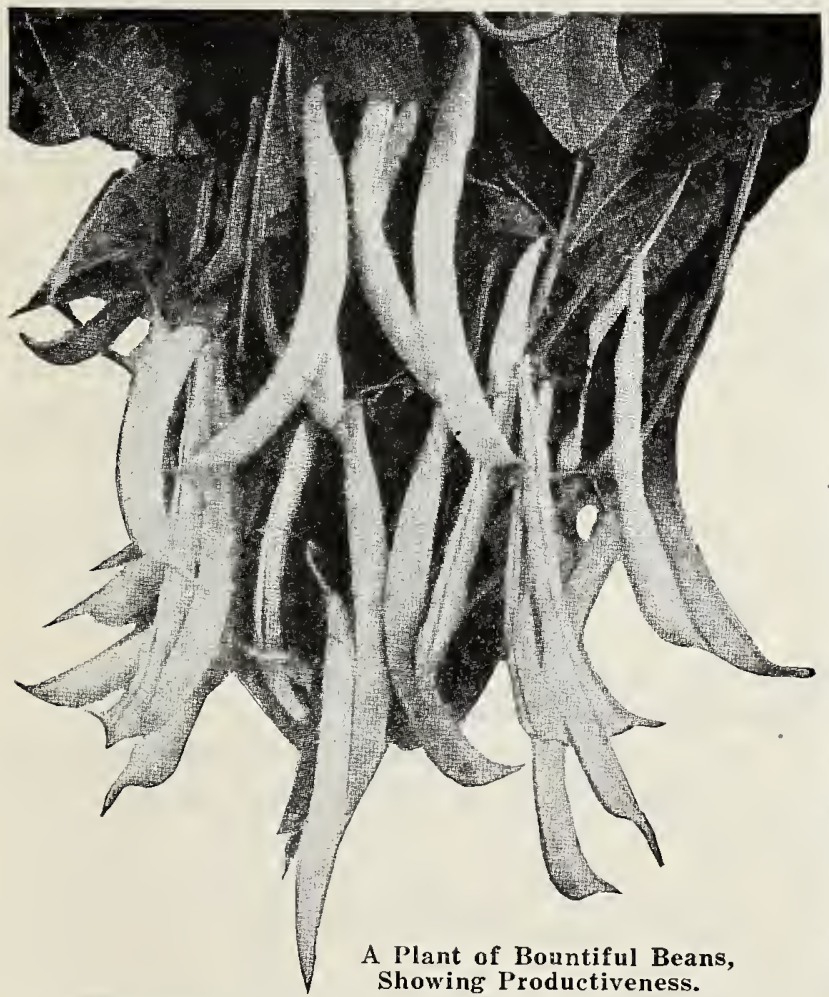

Black Valentine Beans.

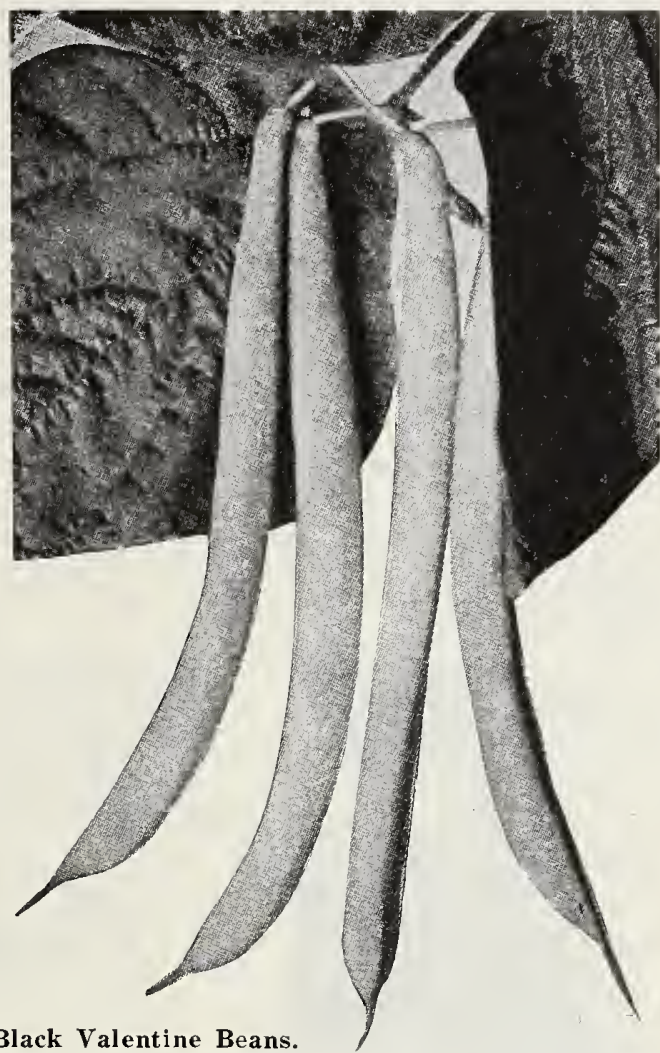

Mammoth Stringless Valentine. This variety Mammoth Stringless Valentine. for second crop or mid-summer planting is one of the best. The pods somewhat resemble those of Stringless Green-pod, but are longer, nearly straight, and of the same splendid quality. A good home garden sort, as it is fine for canning. Pkt. $10 \mathrm{cts}$., $1 / 2$ lb. 25 cts., 1 Ib. 45 cts., 2 lbs. 80 cts., 4 lbs. $\$ 1.50,10$ lbs. \$3.00. Postpaid.

Stringless Green Pod. In many sections of the podded bean is considered one of the best for either early market or the home rarden. The pods are of medium length, slightly curved, stringless, very fleshy, of the best quality, and remain in edible condition for a long period of time. Pkt. 10 cts., $1 / 2$ lb. 25 cts., 1 lb. 45 cts., 2 lbs. 80 cts., 4 lbs. $\$ 1.50,10$ lbs. $\$ 3.00$. Postpaid.

Red Valentine. For nearly 50 years, our market gardenthe great trucking beans of the South planting in mid-summer, it has been superseded by the Black Valentine. The pods are of medium length, curved, of good quality, but not stringless. Pkt. 10 cts., $1 / 2$ lb. 25 cts., 1 lb. 45 cts., 2 lbs. 80 cts., 4 lbs. \$1.50, 10 lbs. \$3.00. Postpaid. Full Measure. A fine medium early stringless green are round and fairly straight. A good sort for midseason and fall crop. Pkt. 10 ets., $1 / 2$ lb. 25 cts., 1 lb. 45 cts., 2 lbs. 80 cts., 4 lbs. $\$ 1.50,10$ lbs. $\$ 3.00$. Postpaid.

Refugee, or 1000 to 1 . A late variety, popular argely grown with canners and more other variety. The pods are nearly round, medium long, and while not entirely stringless, are of splendid quality. Very prolific. Pkt. 10 cts., $1 / 2$ lb. 25 cts., 1 lb. 45 cts., 2 lbs. 80 cts., 4 lbs. $\$ 1.50,10$ lbs. $\$ 3.00$. Postpaid.

Remember we deliver free at catalogue prices-except where noted. Write for special prices in large quantities, 


\section{DWARF OR BUSH WAX PODDED BEANS}

Tait's Thoroughbred Celestial Wax. In our ceaseless effort after improvement, we occasionally find a fusion, a new name is required for identification. In the Celestial, we offer an improved strain of the California if our own opinion, and the judgment of the best Southern that we could not well retain the old of the improvement is such that we could not well retain the old name for both beans. Early and handsome as the California Wax is, our Celestial is several days earlier, and has a decidedly longer pod and better color, the bush being remarkable for its strength and treelike erectness. It resists disease much better than any Black Seeded Wax. Pkt. 10 cts., 1/2 lb. 30 cts., lb. 50 cts., 2 lbs. 90 cts., 4 lbs. $\$ 1.75,10$ Ibs. $\$ 3.50$. Postpaid.

\section{Tait's Thoroughbred Norfolk Wax.}

After several years of careful breeding, and field tests by some of our best bean growers, we offer this variety to our trade, believing it disease, with plenty of foliage, and are loaded with slightly curved, handsome particularly strong, vigorous, and free from low. We urge our customers to be sure to give it a trial this spring. Pkt. 10 cts., 1/2 lb. 30 cts., 1 lb. 50 cts., 2 lbs. 90 cts., 4 lbs. \$1.75, 10 Ibs. \$3.50. Postpaid.

Currie's Rust Proof Wax. An improvement on the old Golden Wax, and once the standard black-seeded variety, flat, golden yellow, but not of the best quality. Pkt. 10 cts., $1 / 2$ lb. 25 cts., 1 lb. 45 cts., 2 lbs. 80 cts., 4 lbs. $\$ 1.50,10$ lbs. $\$ 3.00$. Postpaid.

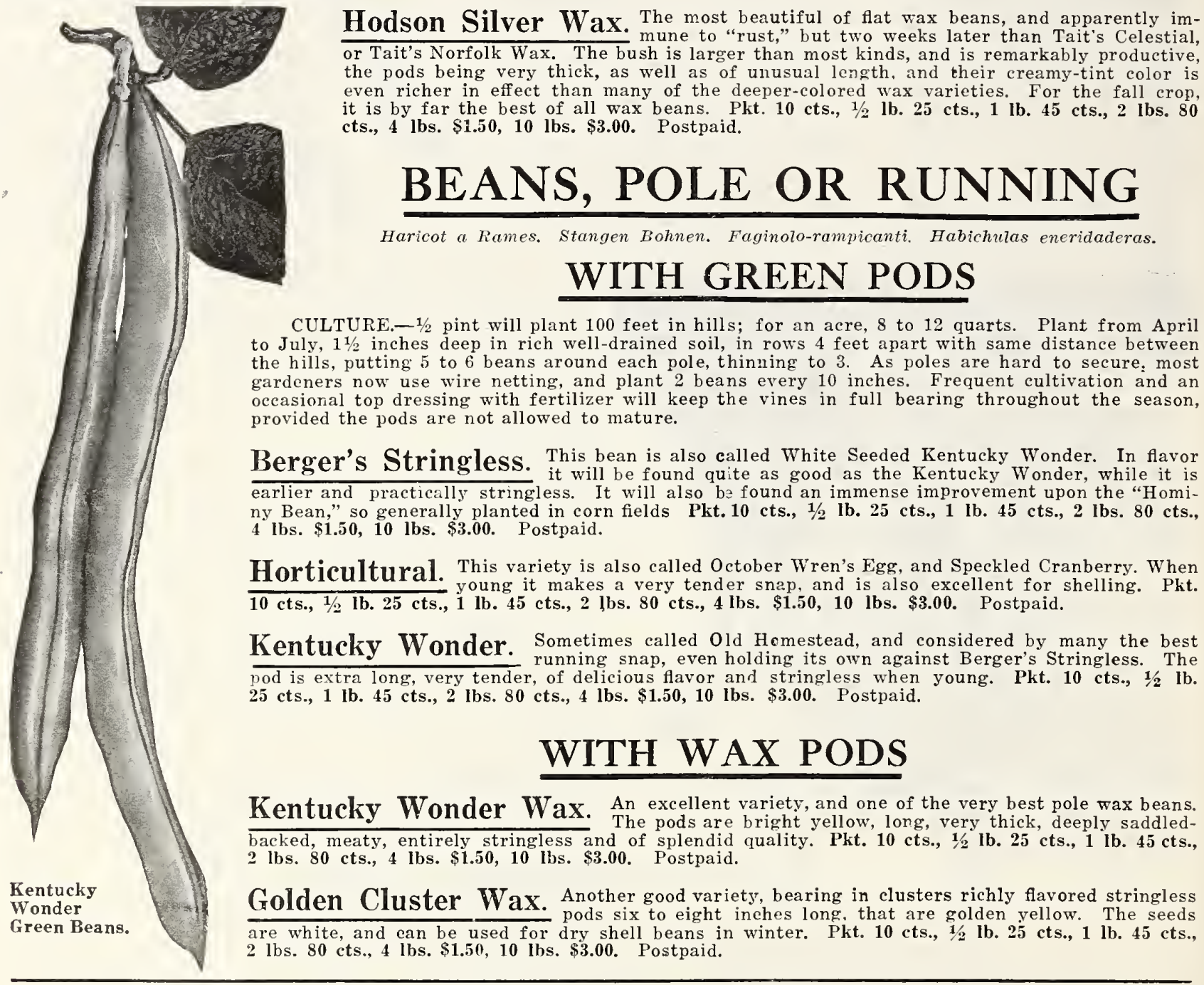

Remember we deliver free at catalogue prices-except where noted. Write for special prices in large quantities. 


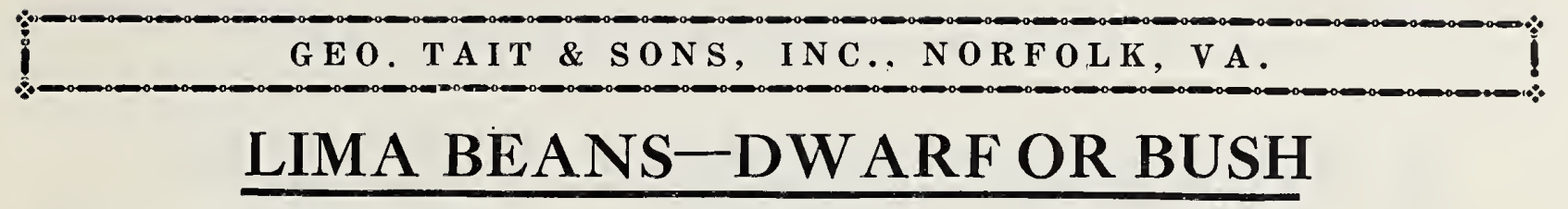

(Phaseolus Lunatus.)

A pint equals about one pound; a bushel equals about sixty pounds.

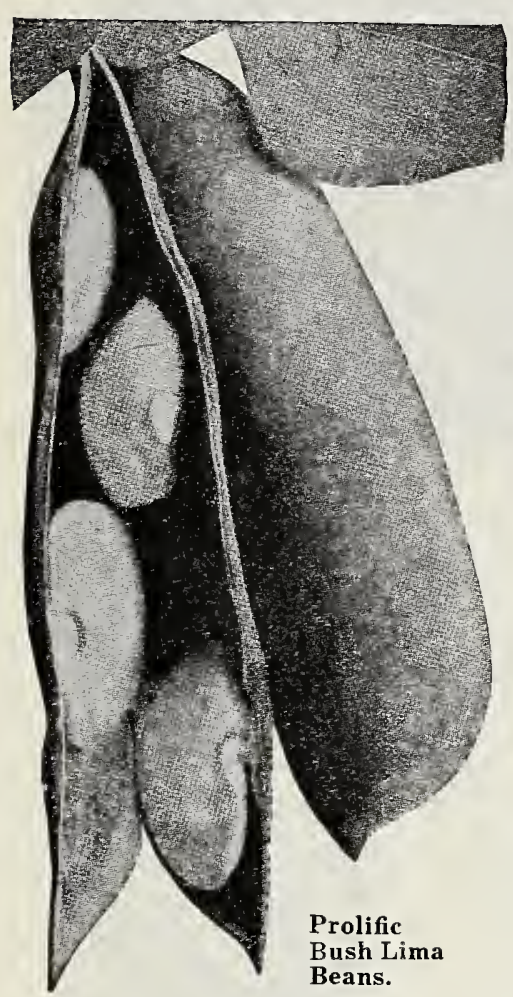

CULTURE-1 pint of Bush Limas will sow 100 feet of drill. For an acre about 3 pecks of small and $1 \frac{1 / 2}{2}$ bushels of the large. Plant from May to July $1 \frac{1 / 2}{2}$ inches deep, the rows for the large should be 3 feet, with 15 to 18 inches between the plants, and for small $2 \frac{1}{2}$ feet, with 10 to 12 inches between the plants. We find that almost all dissatisfaction with the yield of Bush Limas is due to lack of cultivation, and too much emphasis cannot be laid upon the necessity for systematic stirring of the surface. If put in rich soil and properly cultivated, they will bear steadily throughout the summer. There is no reason why Lina Beans should not be started under protection in the same way as muskmelons, thus prolonging the bearing season a fortnight or more, and we are sure that all who can conveniently handle them thus will be delighted with the results.

Prolific Bush. Since its introduction, this small Bush Lima, or "Butter Bean," 11. BuSh. has steadily grown in favor, and with the possible exception of Fordhook, is more largely grown than any other bush lima. It is a distinct and valuable improvement on the original First Early Small Bush Lima, making a much larger growth-in fact, in its early stage, looks as though it would put forth runners-but it is of true bush form, bearing from early summer to frost. enormous quantities of pods containing beans of good size and delicious flavor. Pkt. 10 ets., $1 / 2$ lb. 25 cts., 1 lb. 45 cts., 2 lbs. 80 cts., 4 lbs. $\$ 1.50,10$ lbs. \$3.00. Postpaid.

First Early. The earliest of the Bush Limas, but very small, requiring much First Early. labor in picking and shelling, and has nearly gone out of use since the introduction of the Prolific described above, which is only about a week later. Pkt. 10 cts., $1 / 2$ lb. 25 cts., 1 lb. 45 cts., 2 lbs. 80 cts., 4 lbs. $\$ 1.50,10$ lbs. $\$ 3.00$. Postpaid.

Early Wilson. This remarkable Bush est acha represents the latean breeding, and is the earliest of the large Flat bush sorts. The plants are strong and true bush form, averaging about two feet in height, and are of healthy and sturdy growth. It is very prolific, bearing in clusters the pods, which contain usually four large beans of the best quality. Pkt. 10 cts., $1 / 2$ lb. 30 cts., 1 lb. 50 cts., 2 lbs. 90 cts., 4 lbs. $\$ 1.75,10$ lbs. $\$ 3.50$. Postpaid.

Fordhook. Thicker and rounder than the potato type is very popular, and, in our judgment, the best Large Bush Lima, either for private or market gardeners. The plant is very sturdy, and aithough remarkably bushy, holds itself stiffy erect throughout the season, carrying the pods well clear of the ground. Under thorough cultivation, the bush will grow two feet or more in height, and often measure two feet across, the main stalk and lateral branches producing in clusters pods each containing from four to five large beans of the most delicious flavor. Pkt. $10 \mathrm{cts}$., $1 / 2 \mathrm{lb} .30 \mathrm{cts} ., 1 \mathrm{lb}$. 50 cts., 2 lbs. 90 cts., 4 lbs. $\$ 1.75,10$ lbs. \$3.50. Postpaid.

\section{ENGLISH BROAD BEANS}

CULTURE.-Unlike our Lima Beans, which they somewhat resemble, the English Broad Beans are so hardy that they can be planted as early as February in ordinary seasons. When gathered young and properly cooked, they are not inferior to our Lima Beans, and we recommend them for sections where short seasons with cool nights make Lima Beans uncertain.

Broad Windsor. The best liked and largest variety. Pkt. 10 cts., 1/2 lb. 30 Postpaid. cts., 1 lb. 50 cts., 2 lbs. 90 cts., 4 lbs. $\$ 1.75,10$ lbs. $\$ 3.50$.

Mazagan. The earliest variety but not as large as Broad Windsor. Pkt. 10

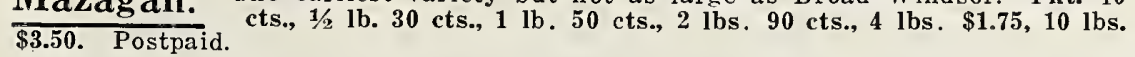

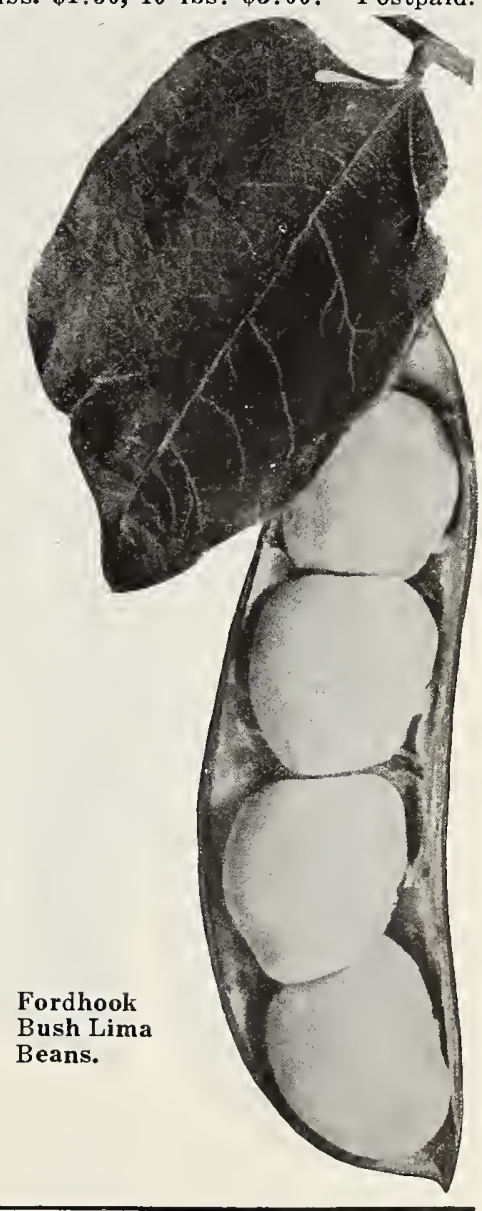

Remember we deliver free at catalogue prices-except where noted. Write for special prices in large quantities. 


\section{LIMA BEANS--POLE OR RUNNING}

CULTURE.-1 pint of large or half a pint of small Pole Limas will plant 100 hills. For an acre, 1 peck of the small and 3 pecks of large. Plant from May to July $1 \frac{1 / 2}{2}$ inches deep. If poles are used for support, they should be set about 4 feet apart each way. If it is not convenient to get poles, wire netting or strong fish twine make an excellent support, and many gardeners now use nothing else. 5 or 6 beans are planted to each pole, so as to ultimately leave 2, or if put beside netting two beans every 10 inches. Keep the ground well cultivated.

Leviathan The earliest large pole lima and best for sections where the arowing season is short. The pods are long, nearly straight and the beans are of splendid quality. Pkt. 10 cts., $1 / 2$ lb. 25 cts., 1 lb. 45 cts., 2 lbs. 80 cts., 4 lbs. $\$ 1.50,10$ lbs. $\$ 3.00$. Postpaid.

Giant Evergreen. The handsomest and most prolific large pole lima ing very near the ground, bearing enormous quantities of pods filled with four to five large beans of delicious flavor. The beans even when dry retain their beautiful green tint from which the name was derived. Pkt. 10 cts., 1/2 lb. 25 cts., 1 lb. 45 cts., 2 lbs. 80 cts., 4 lbs. \$1.50, 10 lbs. \$3.00. Postpaid.
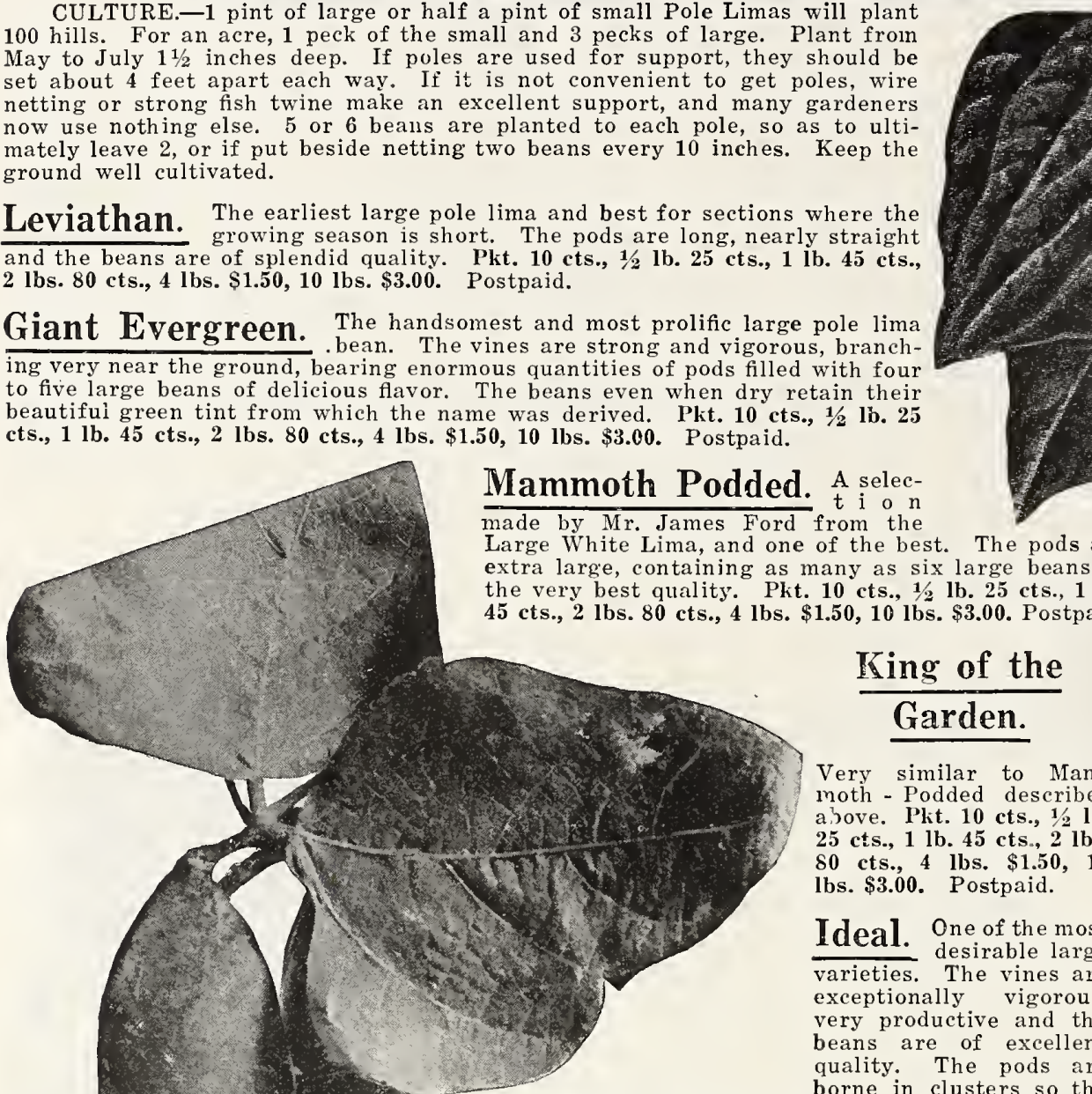

Very similar to Mammoth - Podded described a bove. Plit. 10 cts., $1 / 2$ lb. 25 cts., 1 lb. 45 cts., 2 lbs. 80 cts., 4 lbs. $\$ 1.50,10$ lbs. \$3.00. Postpaid.

Ideal. One of the most desirable large varieties. The vines are exceptionally vigorous, very productive and the beans are of excellent quality. The pods are borne in clusters so the

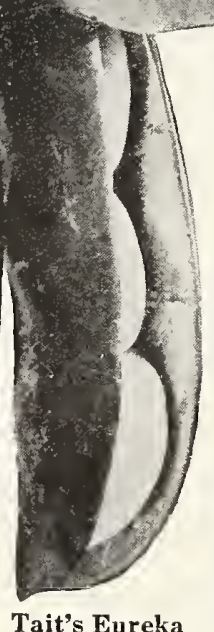

Tait's Eureka Medium

Pole Lima Beans. gathering is easily done. Pkt. 10 cts., $1 / 2$ lb. 25 cts., 1 lb. 45 cts., 2 lbs. 80 cts., 4 lbs. $\$ 1.50,10$ lbs. $\$ 3.00$. Postpaid.

Tait's Thoroughbred Eureka. This selection we made from the Small Pole Lima, or "Butter Bean," and at once became so popular that up to the present time, we have never been able to supply the demand. In our tests, it is a trifle earlier than the Small Pole Lima, more prolific, with longer pods that form in clusters from early fall until frost. The beans are also nearly double the size of the old variety, and of the same good quality. Pkt. 10 cts., $1 / 2$ lb. 30 cts., 1 lb. 50 cts., 2 lbs, 90 cts., 4 lbs, $\$ 1.75,10$ lbs, $\$ 3,50$, Postpaid,

Small Sieva or Sewee. Previous to the introduction of Tait's Eureka, the Sewee or small Butter Bean was more largely grown than any other kind in the South. It is extra-ordinarily productive, yielding abundantly until frost, and for this reason is still a favorite with market gardeners. Pkt. 10 cts., 1/2 lb. 25 cts., 1 lb. 40 cts., 2 lbs. 75 cts., 4 lbs. $\$ 1.35,10$ lbs. $\$ 2.75$. Postpaid.

Giant Evergreen Pole Lima Beans.

Remember we deliver free at catalogue prices-except $w$ here noted. Write for special prices in large quantities. 


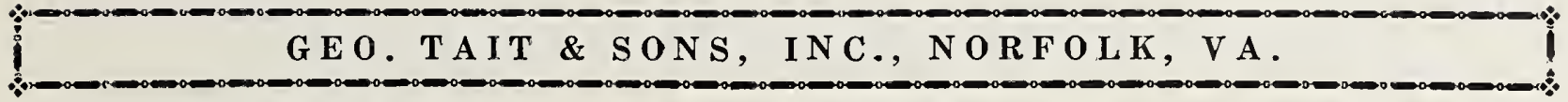

\section{B EETS}

(Beta Tulgaris.)

Betterave. Salatruben. Barbabietoia. Remolacha.

CULTURE.-2 ounces are sufficient for 100 feet of drill, 4 to 10 pounds being allowed to the acre. To obtain very early beets, the Egyptian, Crosby's Egyptian, Detroit and Eclipse should be sown in hot-beds $3 / 1$ of an inch deep in December, transplanting being done in the open ground as early as the season will permit; in rows not less than 18 inches apart or on beds 4 feet wide with 12 to 15 inches between the rows, setting plants 4 to 6 inches apart. Outdoor sowings are made from the middle of February until August, an interval of 2 weeks between sowings making the proper succession. The cultivation should be constant, and only well-rotted manure used. When sown in cold frames they are usually planted in 8-inch rows with 3 or 4 inches between the plants. Beets grown for sugar making must not be stirred after the roots are formed, as the strength which should go into the sugar is liable to be directed into new and useless fiber.

Early Wonder. A splendid vamended to market gardeners who desire an extra early outdoor beet of desirable shape and color. The root is globular shaped, of a beautiful blood-red color and of splendid quality. Its uniform size, shape, color, and excellent keeping qualities have made it deservedly popular with both home and market gardeners. Pkt. 10 cts., oz. 15 cts., 1/1 lb. 40 cts., 1 lb. $\$ 1.25$. Postpaid. Crosby's Egyptian. Our market gardeners strain of this well-known and de-

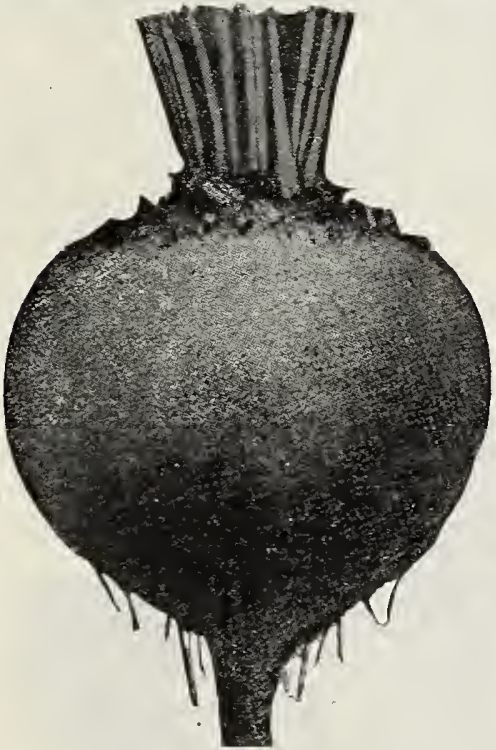

Detroit Beet. Egyptian, from which it was selected by Mr. Josiah Crosby. The roots are flattened globe shaped, and of a bright red color, and of splendid quality. The tops resemble those of the older variety, being few in number and small. Good for both market and the home garden. Pkt. 5 cts., oz. 10 cts., $1 / 1$ lb. 25 cts., 1 lb. 90 cts. Postpaid.

Detroit. None of the globe-shaped beets for the main crop are as dark in color Tetroit. as this, and it is also remarkable for uniformity in size and shape. The skin is very smooth, the flesh crisp, tender, sweet, and extremely tenacious of its brilliant color, and for this reason is preferred by canners. Southern growers however prefer our Early Wonder and Market Gardeners strain of Crosby's Egyptian. Northern and Western gardeners use it quite largely. A splendid kind for home, and market gardeners. Plit. 5 cts., oz. 10 cts., 1/4 lb. 25 cts., 1 lb 90 cts. Postpaid. Eclipse. Once largely used by market gardeners, this handsome beet has been Detroit. superseded in most sections by Early Wonder, Crosby's Egyptian, and The roots are round, slightly top-shaped, and of a bright red color. A good sort for the home garden, for both early and mid-season sowing. Pkt. 5 cts., oz. 10 cts., $1 / 4$ lb. 25 cts., 1 lb. 90 cts. Postpaid.

Extra Early Egyptian. The favorite with market gardeners for growflat dark red roots and is the earliest under glass. Our strain has small tops, for this purpose. The flesh is tender while young, but soon becomes woody and therefore should not be used in the family garden. Pkt. 5 cts., oz. 10 cts, 1/4 1b. 25 cts., 1 lb. 90 ets. Postpaid.

Long Smooth. An improved stock of the old long blood beet, roots quite L long, almost cylindric, well colored, uniform in size, but late in maturing. Pkt. 5 cts., oz. 10 cts., $1 / 4$ lb. 25 cts., 1 lb. 90 cts. Postpaid.

\section{SUGAR BEETS}

Klein Wanzleben. The most desirable variety to grow, as it contains the greatest percentage of sugar. Heavy

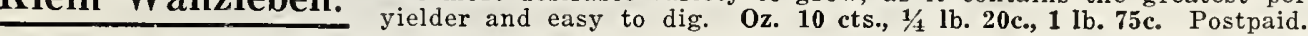

Imperial White. One of the best and sweetest of Sugar Beets, yields nearly as heavy as the Mangel; contains about 15 per cent. sugar.

Oz. 10 cts., $1 / 4$ lb. 20 cts., 1 lb. 75 cts. Postpaid.

Remember we deliver free at catalogue prices-except where noted. Write for special prices in large quantities. 


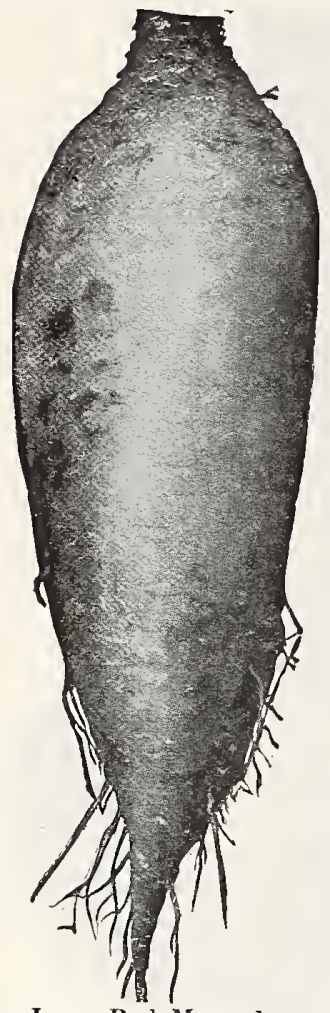

Long Red Mangel.

\section{STOCK BEETS}

CULTURE. 6 to 8 pounds of seeds are allowed per acre, and they are planted from April to July. Field beets are handled in much the same way as the garden varieties, except that the drills must be at least 2 feet apart, and the plants are thinned to about 10 inches in the row. Cultivation must be constant and thorough to keep down the weeds until the plants are well developed.

Golden Giant. The largest yellow mangel; the roots are smooth, even in shape, and have white, firm and sweet. This is one of the grow half out of the ground; the flesh is a yellowish cts., $1 / 4$ Ib. 20 cts., 1 lb. 60 cts. Postpaid. Mammoth Long Red. An improved strain of the Long Red, which grows very large and red color, and does best on light well out of the ground. It has long, straight roots of a medium Oz. 10 ct s., $1 / 4$ lb. 20 cts., 1 lb. 60 cts. Postpaid.

. cultural Exhibitions. The color is arded the highest honors in the Danish Agriand while the roots do not heavier. heavier. A most desirable sort. Oz. 10 cts., 1/4 1b. 20 cts., 1 lb. 60 cts. Postpaid.

Yellow Globe. A large and productive variety. It keeps well, and is the best kind for soils which are rather shallow. Oz. 10 cts., 1/4 lb. 20 cts., 1 lb. 60 cts. Postpaid.

\section{B R O C COL I}

(Brassica Oleracea Botrytis.)

Chou Brocoli. Spargéikohl. Brocoli. Broculi.

CULTURE.-1 ounce is enough for 100 feet of drill, $1 / 1$ of a pound will produce enough plants to set an acre. For the main crop, sow in April in a well-pulverized bed or in November in hot-bed $1 / 2$ an inch deep. When the plants are large enough transplant into rows of deep, rich soil, leaving 30 inches between the plants each way. Give water plentifully at all stages of their growth, as the plants are peculiarly dependent upon moisture.

Early White Cape. In its general habit Broccoli resembles cauliflower, to which, howons, with large white heads, that are it is much inferior in flavor. This variety is hardy and vigorPostpaid.

Italian Green Sprouting. A delicious vegetable which should be more largely grown. head and is used without blanching. Pkt. 15 cts., oz. 75 cts., $1 / 1$ lb. $\$ 2.25,1$ lb. $\$ 7.50$. Postpaid.

\section{BRUSSELS SPROUTS}

(Brassica Oleracea Bullata.)

Choude Bruxelles. Rosenkohl. Cavolo di Brusselles. Berzade Brusels.

CULTURE.-I ounce is sufficient for 100 feet of drill, $1 / 4$ of a pound will produce sufficient plants to set an acre. Sow in April or September in beds $1 / 2$ inch deep and transplant when large enough to rows $2 \frac{1}{2}$ feet apart, allowing the same distance between the plants in the row. Cultivate as for late Cabbage. If the leaves at the top of the stalk crowd the little heads they should be removed. In very dry seasons keep the surface of the ground constantly stirred to retain moisture unless watering is practicable.

Long Island Imp'd. This fine selection has become the favorite owing to its hardiness and the perfection of the when packed in quart baskets for market. Pkt. 15 cts., oz. 50 cts., 1/4 lb. \$1.50, 1 lb. \$5.00. Postpaid.

Hercules, A semi-dwarf variety of robust growth, bearHercules. ing round solid sprouts, that begin close to the ground. Not so early as Tait's Long Island. Pkt. 10 cts., oz. 25 cts., $1 / 4$ Ib. 75 cts., 1 Ib. $\$ 2.50$. Postpaid.

\section{B U R N E T}

(Poterium Sanguisorba.)

CULTURE.- 1 ounce of Burnet is sufficient for 100 feet of drill, 2 to 5 pounds for an acre. No plant is more easily grown than this, as it really takes care of itself when once started. The seed should be sown 1/4 inch deep early in spring, with the rows about 18 inches apart; and 6 to 10 inches between the plants; if desired the bed can be readily enlarged by division of the clumps.

The leaves of Burnet have a piouancy which makes them excellent for flavoring either salads, stews or soups. Garden. Pkt. 5 cts., oz. 10 cts., $1 / 4$ Ib. 30 cts., 1 Ib. $\$ 1.00$.

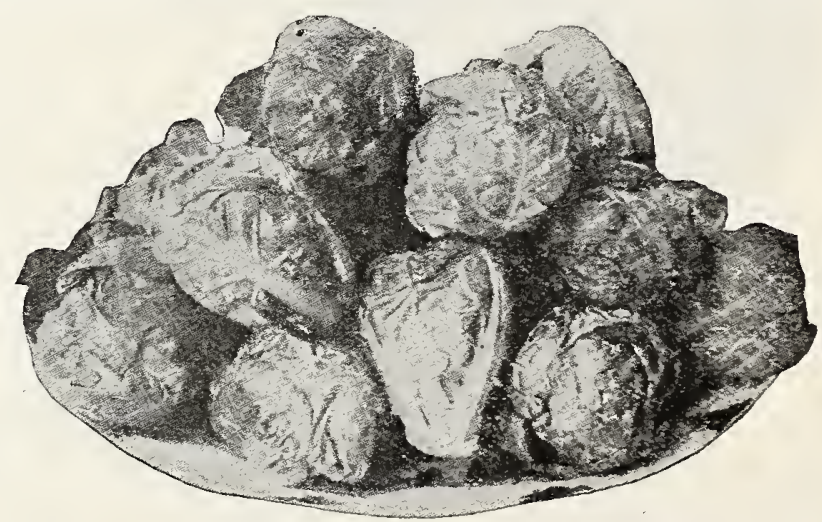

Long Island Improved Brussels Sprouts.

Remember we deliver free at catalogue prices-except where noted. Write for special prices in large quantities. 


\section{OUR FROST-PROOF GABBAGE PLANTS}

Will Mature Heads Two to Three Weeks Earlier Than Your Home Grown Plants and Double Your Profits.

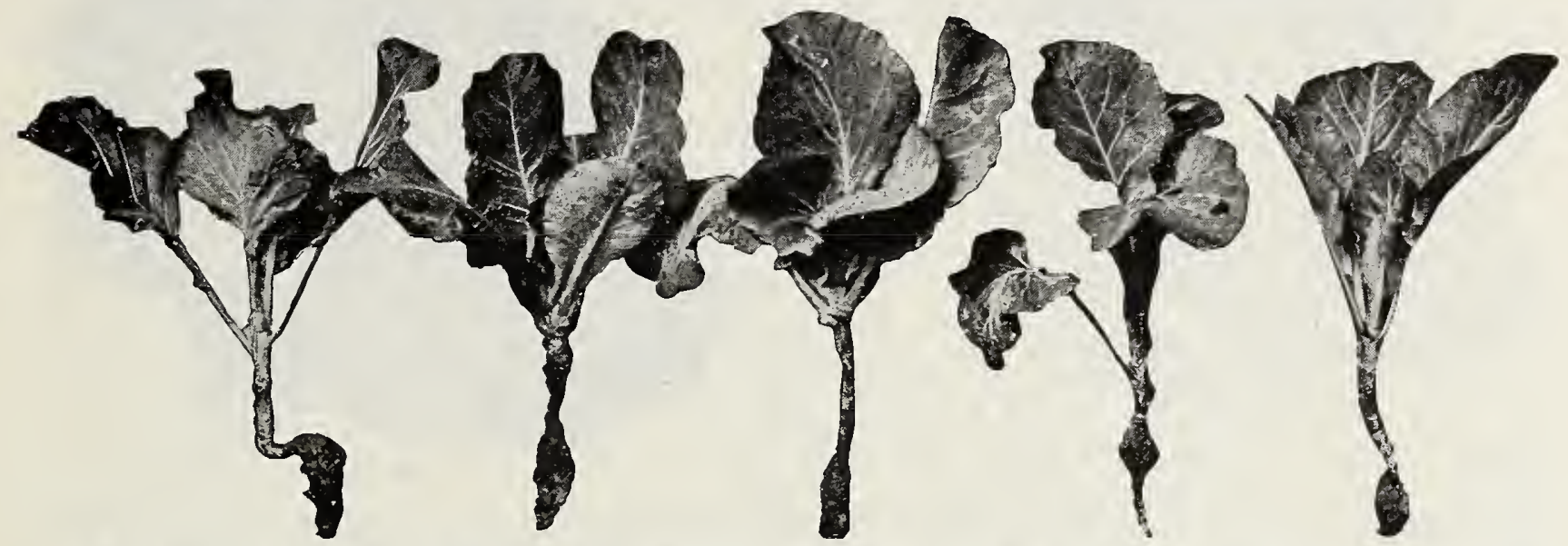

These plants are grown along the Sea Coast of South Carolina, where the soil and climatic conditions are just suited for growing tough, hardy cabbage plants during the Winter and early Spring. The plants make a slow but steady growth, until at eight to ten weeks of age they are very tough and hardy, the buds are purple and the outer leaves a reddish brown. When in this condition they can be shipped to territory farther north and be planted in the open ground a month to six weeks sooner than the home-grown hot bed or cold frame plants. These Frost-Proof Cabbage Plants will stand a temperature of 20 degrees above zero without injury. The land freezing, or the plants being covered with ice, sleet or snow after they are planted will not injure them, providing temperature does not go below 20 degrees above zero.

The top of the plant does not grow until your regular Spring weather opens up, but the roots grow from the time they are planted, and just as soon as spring weather starts, the established root growth assimilates the fertilizer in the soil, the plants grow very fast, maturing headed cabbage two to three weeks sooner than you can mature them from hot bed and cold frame plants. You know what the difference in profit will be if your crop is matured and marketed before the general crop from home-grown plants is matured.

To get the advantage of these Frost-Proof Cabbage Plants they must be planted a month or six weeks earlier than you would plant home-grown plants. We fill orders from December 1st to May 1 st.

\section{(Cash Must Accompany All Orders for Plants)}

ORDER EARI,Y TO GET PLANTS DELIVERED IN TIME
When we receive your order for these plants, we have to forward it to our growing station, which takes several
Plants are shipped direct to you from growing station. Plants cannot be pulled or shipped when beds are
days.
wet. We sometimes have a week or ten days of continued wet weather which prevents shipment. If you co not re- $\overline{\bar{E}}$
ceive your plants as soon as you expect them, you will know that weather prevents shipment. Send your order two
to three weeks before you expect to set the plants and you will get them on time.
The plants when received will be somewhat wilted and have a hard stunted appearance, which will be disappointing
to persons who have never used these plants before. Regardless of appearance, they will produce the crop results.

\section{VARIETIES: EARLY JERSEY WAKEFIELD, CHARLESTON OR LARGE WAKEFIELD, SUCCESSION AND EARLY FLAT DUTCH}

Prices by Parcel Post, postage paid. In lots of $100,200,300$, or 400 plants at 50c per 100 plants; 500 plants for $\$ 1.60$; 1,000 or more at $\$ 3.00$ per 1,000 plants.

Orders are filled by the 100 , not 250 or 350 . These prices are for even quantities of one variety to package; if you ordered 200 of one variety and 300 of another variety you would pay at the 100 rate.

Prices by Express, buyer paying express charges. In lots of 1,000 to 3,000 plants at $\$ 2.00$ per 1,$000 ; 5,000$ or more at $\$ 1.80$ per 1,000 . Plants packed for express shipment, 1,000 or 2,000 plants of a variety to package, they weigh about 25 pounds per thousand plants, packed for shipment.

We can also supply FROST PROOF ONION PLANTS. See page 34 .

Remember we deliver free at catalogue prices-except where noted. Write for special prices in large quantities. 


\section{G A B B A GE}

(Brassica Oleracea Capitata.)

Chou Pomme. Kopfkohl, Kraut. Cavolo cappuccio. Col. repollo.

CULTURE:-1 ounce is sufficient for 100 feet of drill, 8 ounces will give enough plants for an acre. For early spring cabbage, sow $1 / 1$ of an inch deep from the middle of September to the middle of October, and when the plants are large enough transplant in rows $2 \frac{1}{2}$ feet apart, leaving about 15 inches between the plants, but many successful growers are now setting them as close as 12 inches. When a supply of plants has not been secured in the fall, sow in cold frames in December, or in a gentle hot-bed the last of February; give plenty of air at proper times in order to harden the plants and transplant in the open ground as soon as the weather permits. For a summer crop, sowings may be made in March until the middle of May. For winter cabbage sow Flat Dutch, Drumhead, and Savoy from middle of May to last of July, transplanting when large enough; late cabbage should be set 3 feet apart and not less than 18 inches in the row. It is useless to attempt the cultivation of this crop without deep and thorough plowing or spading and an abundance of rich, well-decomposed manure or suitable substitutes. Frequent stirring of the soil is essential especially when seasonable rains are lacking.

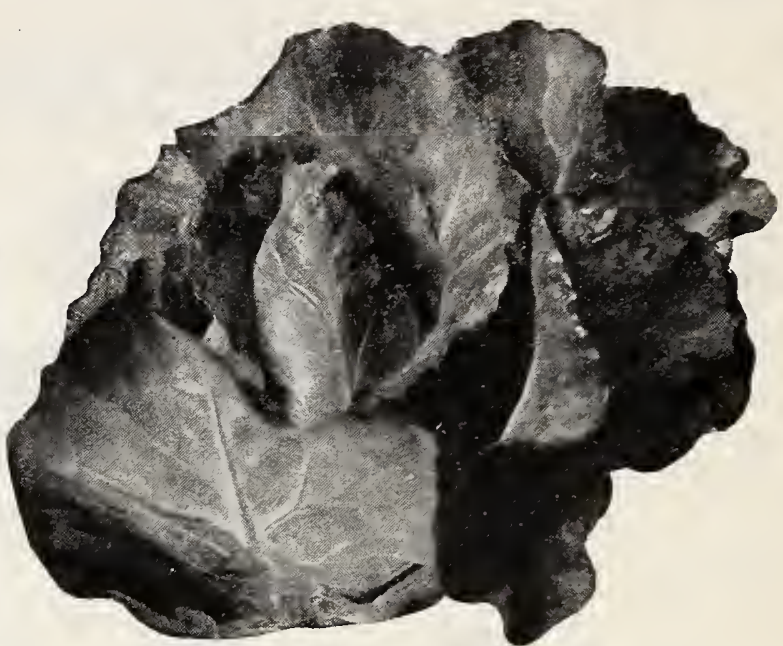

Tait's Thoroughbred Pilot Cabbage.

Each time the ground is worked it should be drawn up a little more around the stem until the head begins to form, when one final, thorough cultivation should be given. Many successful gardeñers grow cabbage without transplanting, sowing the seed thinly in drills or in hills, and afterwards thinning to the proper distance in the row.

\section{EXTRA E A R LY}

Tait's Thoroughbred Pilot. This remarkable cabbage is the earliest in cultivation; ready for market quite pore three weeks in advance of the Selected Wakefield, and is yearly becoming more conical shape of the head allows nearly thirty per cent more plants to the acre than of any other cabbage, and it is therefore very economically grown. The flavor is so exceptionally delicate and mild that it is well adapted for family use, although brought out especially for truckers, and all who grow cabbage at all should have a portion of their crop in this kind. Although admittedly less hard than many of the later varieties, it is not an uncommon thing for the Pilot to sell for profitable prices when the Wakefield and similar cabbages fail to bring even the cost of shipment. Pkt. 10 cts., oz. 45 cts., $1 / 4$ lb. $\$ 1.25,1$ lb. $\$ 4.50$. Postpaid.

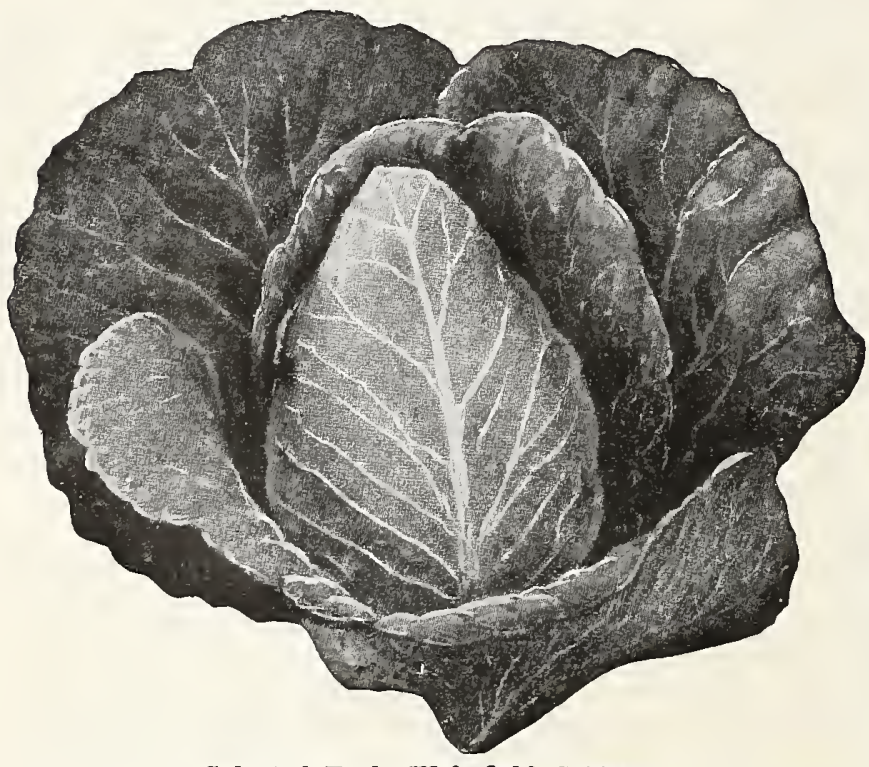

Selected Early Wakefield Cabbage.

\section{E A R L Y}

Selected Wakefield. This new strain is a selection from the True Early Wakefield, and is about a week earlier in heading. It is the same shape as the True Early Wakefield, possibly a trifle smaller, but very uniform in heading. All growers of Early cabbage should use it in connection with our Large Wakefield. Pkt. 10 cts., oz. 30 cts., $1 / 4$ lb. 90 cts., 1 lb. $\$ 3.00$. Postpaid.

\section{Tait's Thoroughbred True Wakefield.}

The Wakefield cabbage has been for many years the leading sort in America. There are, however, numerous stocks of this variety, but we believe that in our Thoroughbred strain of True Wakefield, we have the best early cabbage, where only one sort is sown. Larger and a full week earlier than any other strain of Early Wakefield, except our new Selected Wakefield; this splendid variety is undoubtedly one of the finest early cabbages in existence. The heads are extremely solid, conical in shape, and have few outside leaves. It is grown under special supervision by a most careful and experienced farmer on Long. Island and is the kind preferred by truckers and market gardeners from Norfolk to Florida. Pkt. 10 cts., oz. 35 cts., $1 / 4$ lb. $\$ 1.10,1$ lb. $\$ 3.75$ Postpaid. 
Tait's Thoroughbred Norfolk Wakefield. In our ceaseimprove the Wakefield Cabbage we have succeeded in developing a Large Wakefield that will average nearly as large as the Charleston Wakefield, but which comes in about ten days earlier, but with fewer outside leaves. We believe it is what Market Gardeners have been looking for and we urge all cabbage growers to give it a trial. Pkt. 10 cts., $02.45 \mathrm{cts} ., 1 / 4 \mathrm{lb} . \$ 1.25$, lb. \$1.50. Postpaid.

Large or Charleston Wakefield A fine selection from the and has steadily grown in favor especially in South Carolina, its popularity in the cabbage-growing district about Charleston being such that it is often called the Charleston Wakefield. It is about ten days later than Tait's Selected Early Wakefield, but, on the other hand, it is considerably larger. Pkt. 10 cts., oz. 30 cts., $1 / 1 / 4$ lb. 90 cts., $1 \mathrm{lb}$. $\$ 3.00$. Postpaid.

Tait's Thoroughbred Early Market. For those who head cabbage we recommend this very early sort, a selection from our May Queen, but which matures as early as the Charleston Wakefield. The heads are nedium size, uniform, very hard and of fine quality. Market Gardeners will find it a profitable sort. Pkt. 15 cts., oz. 90 cts., 1/4 Ib. \$2.50, 1 lb. $\$ 9.00$. Postpaid.

Golden Acre. A small early round-headed Cabbage that matures 15olden ACre, about a week earlier than Copenhagen Market. Pkt.

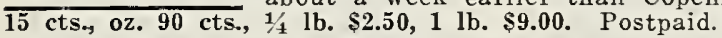

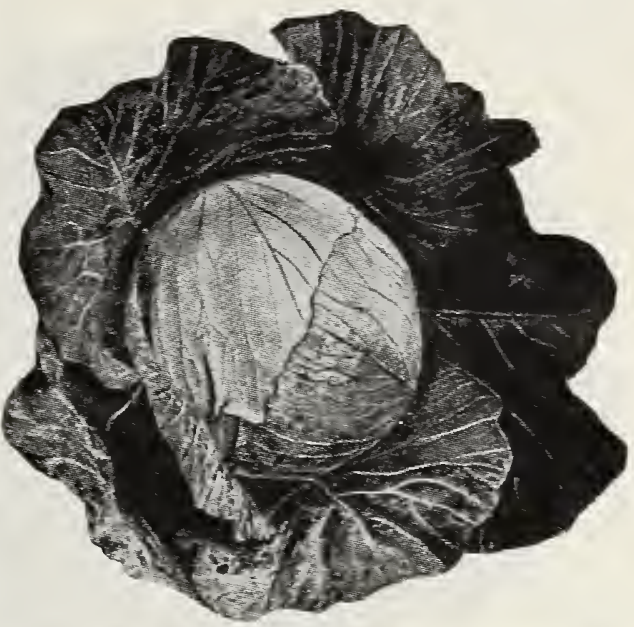

Tait's Thoroughbred Early Market Cabbage.

Tait's Thoroughbred May Queen. This beautiful cabbage, may fairly be said to combine the best qualities of Wakefield. Perhaps its most valuable qualities are its unique and Large Wakefield, and it is but little later than the time of heading, nearly every plant beginning to mature at the same time. Pkt. 10 cts., oz. $45 \mathrm{cts}$., $1 / 4 \mathrm{lb}$. $\$ 1.25,1 \mathrm{lb} . \$ 1.50$. Postpaid.

Copenhagen Market. A round-headed early cabbage of medium size, rery solid, and of good quality. It is very light green and fold tightly. Pht. 10 cts., oz. 40 cts., $1 / 4 \mathrm{lb}$. $\$ 1.25,1 \mathrm{lb}$. $\$ 4.00$. Postpaid.

\section{SECOND EARLY}

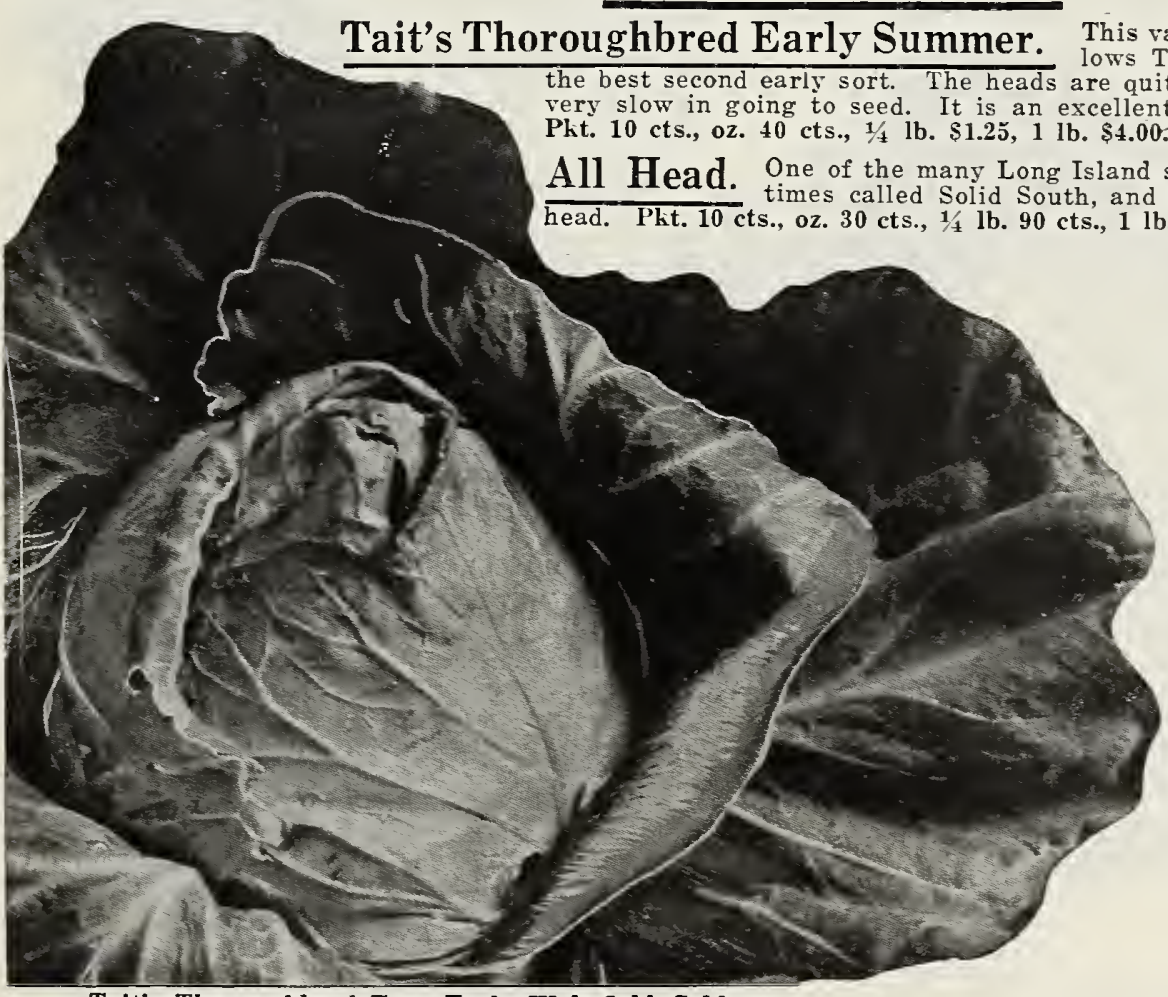

Tait's Thoroughbred True Early Wakefield Cabbage.

\begin{abstract}
T a it's 'Thoroughbred Midsummer. About 10 days Tait's Early Summer. This distinct strain of Flat Dutch we consider a splendid second early variety. The heads are solid, of unsurpassed beauty, and are very uniform. An excellent cabbage for the season after which it is named. Pht. 10 cts., oz. 40 cts., $1 / 4$ lb. $\$ 1.2 \bar{s}, 1$ lb. $\$ 4.00$. Postpaid."

All Seasons. A splendid Dutch originated by a Long Island market gardener and familiar in many places under the name of "Yandegaw." Pkt. 10 cts., oz. 30 cts., $1 / 4$ lb. 90 cts., 1 lb. $\$ 3.00$. Postpaid.

Succession. A well known and uniform in heading, but we prefer Tait's Early Summer or Tait's Midsummer for second early cabbages. Pkt. 10 cts., oz. 30 ets., $1 / 1 /$ lb. 90 cts., 1 lb. $\$ 3.00$. Postpaid.
\end{abstract}

Remember we deliver free at catalogue prices-except where noted. Write for special prices in large quantities. 


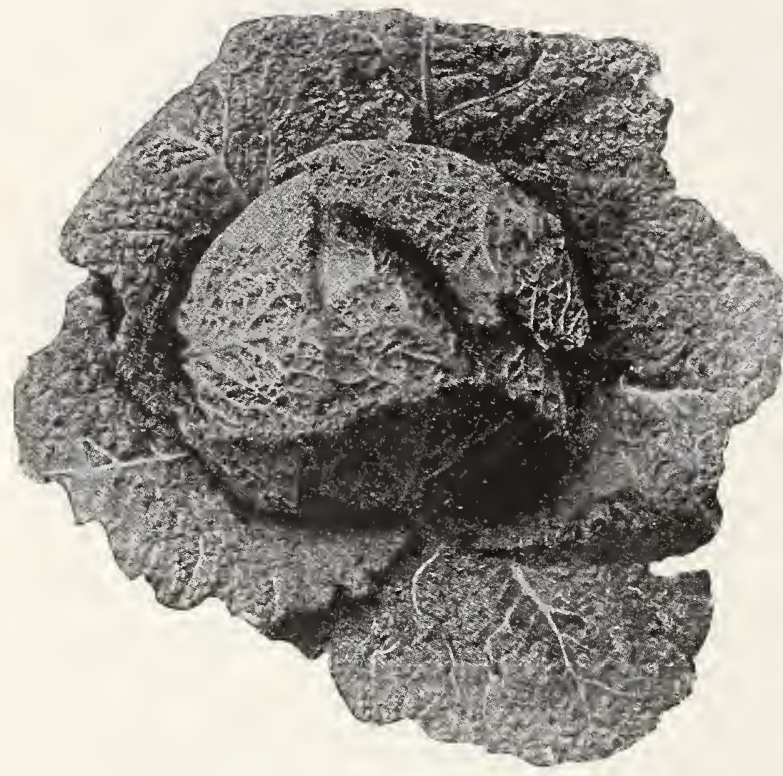

Perfection Drumhead Savoy Cabbage.

\section{CABBAGE---Late Varieties ---Continued}

Perfection Drumhead Savoy. Truckers will find finest strain of that type, the heads being globular, very uniform and firm, with every leaf densely savoyed. It is of delicate flavor, almost like cauliflower, and is excellent for winter use. A splendid home garden variety when sown in mid-summer. Pkt. 10 cts., oz. 40 cts., $1 / 4$ lb. $\$ 1.25,1$ lb. $\$ 4.00$. Postpaid.

Tait's Thoroughbred Winter King. We believe this est of all cabbages, not only in resisting marvelously the ex tremes of heat and cold, or drought and moisture, but showing itself apparently immune to the various fungous diseases so destructive to cabbage. The stem is short, with a hard skin and the dark bluish leaves are noticeable for their thickness and firm texture. The head, although large, is not too large to pack well, is nearly flat, solid and of excellent quality. The "Winter King" may be successfully used for late summer, but it is especially recommended for the season after which it has been named. Pkt. 10 cts., oz. 40 ets., $1 / 4$ lb. $\$ 1.25,1$ lb. $\$ 4.00$. Postpaid.

Tait's Thoroughbred Victor. Our Old Standard Flat ities of which are too well known throughout the Southern States to need any comment. Pkt. 10 cts., oz. 40 cts., $1 / 4 \mathrm{lb} . \$ 1.25,1 \mathrm{lb}$. \$4.00. Postpaid.

Louisville Drumhead. There is no cabbage of the Drumbead type which can be compared with this beautiful representative, its shape, table qualities giving it easily the very first place. While not as large as some of the coarse, inferior kinds, it is of fine size, and very solid. Pkt. 10 cts., oz. 30 cts., $1 / 1$ lb. 90 cts., 1 lb. $\$ 3.00$. Postpaid.

Danish Ballhead. A distinct round head solid cabbage, with short stem, often called . "Hollander," has long been one of the leading exports of Denmark,

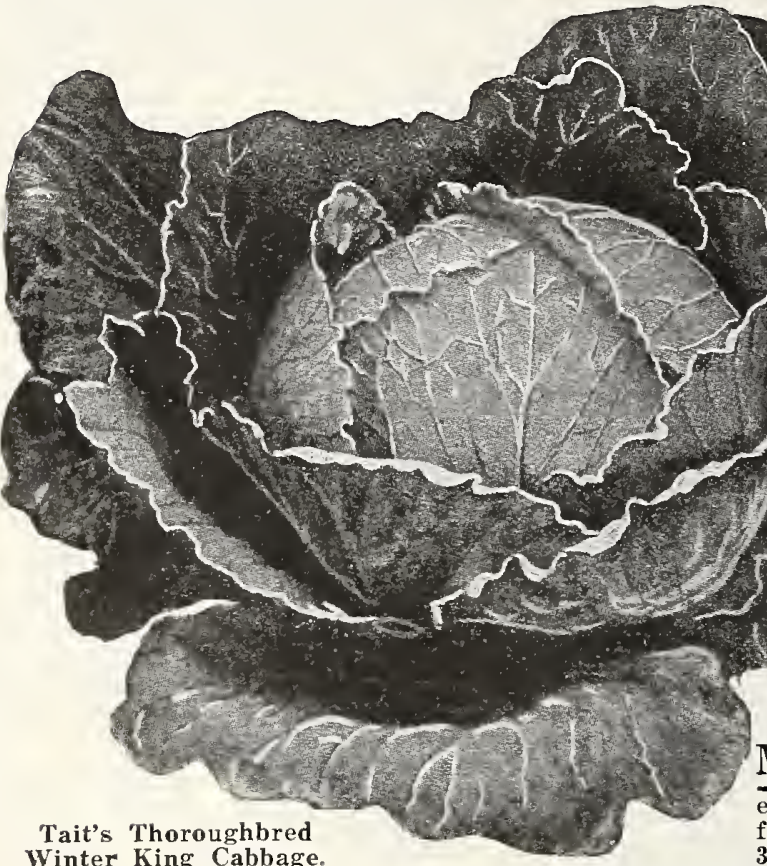

Tait's Thoroughbred e $\mathrm{n} \circ \mathrm{rmous}$ quantities bein $\mathrm{g}$ annually taken by Great $\mathrm{B}$ r it a i $n$ and the Continent; in late years it has become fa $\mathrm{miliar}$ in $\mathrm{t} h$ i s country also. It re$q u$ i $r$ e $s$ strong d e ep soil and cool cli mate to b ring it to perfection, and

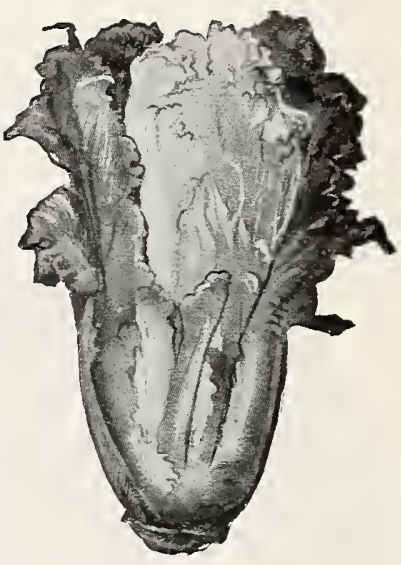

Pe-Tsai

Chinese Cabbage. we f in d it
growing more and more popular, especially in the mountainous sections. Pkt. 10 cts. oz. 40 cts., $1 / 4$ lb. $\$ 1.25,1$ lb. $\$ 4.00$. Postpaid.

Volga. A medium sized main erop cabVage of Russian origin. The heads are round, quite thick through, and not of the best quality. It is a good keeper and a pretty sure header. Pkt. 10 cts., oz. 30 cts., 1/1 lb. 90 cts., 1 lb. $\$ 3.00$. Postpaid.

\section{RED CABBAGE}

Mammoth Red Rock. Market gardeners will find this strain a great improvement over existing varieties. While not early, it is of the best quality, has few outside leaves, and is of the darkest red color. Pkt. 10 cts., oz. 35 cts., $1 / 1 /$ lb. $\$ 1.00,1$ lb. $\$ 3.50$. Postpaid.

\section{CHINESE CABBAGE}

Pe-Tsai Somewhat resembles our Cos Lettuce, and is a very popular vegetable with the Chinese, being used both raw and boiled. It does best as a fall crop. Pkt. 10 cts.; oz. 30 cts., 1/4 lb. 90 cts., 1 lb. $\$ 3.00$. Postpaid.

Remember we deliver free at catalogue prices-except where noted. Write for special prices in large quantities. 


\section{C.ARR OT}

(Daucus Carota.)

Carotte. Carrotten, Mohren. Carota. Zanahoria.

CULTURE.-I ounce is sufficient for 100 feet of drill; 2 to 5 pounds are allowed to the acre. Carrots ought to be sown in light fertile soil, which has been heavily manured for the previous crop, as fresh manure tends to cncourage side roots and irregularity of shape. Sow in drills $1 / 2$ inch deep and 18 inches apart, leaving 3 or 4 inches between the plants, taking care to have the ground deeply worked. If very early carrots are wanted, the short varieties may be sown as early as the ground can be worked, the main crop being usually planted in March, leaving 3 or 4 inches between the plants. For a late crop sow during July, using the stump-rooted or half-long varieties. Carrot seed are very slow in germinating, and should be rolled in firmly to prevent evaporation of moisture while the seeds are sprouting. The same culture given to beets will suit carrots, especial care being taken to keep weeds from getting a start.

\section{Early Scarlet Horn.}

The earliest good variety and the best for forcing. It never grows to much size, and is recommended only for forcing under glass or cotton. The root is thick, dented on the surface, and very sweet. Pkt. 10 cts., oz. $15 \mathrm{cts}$., $1 / 4 \mathrm{lb}$. $35 \mathrm{cts}$., $1 \mathrm{lb}$. \$1.25. Postpaid.

Chantenay. On e of the all Carrots is this fine stumprooted variety, universally esteemed by market gardeners; somewhat like the Oxheart, but smaller in diameter, it grows about six inches long and is of the best quality. One of the best bunching varieties, and equally as good for the home garden. Pkt. 10 cts., oz. 15 cts., $1 / 4$ lb. 35 cts., 1 Ib. \$1.25. Postpaid.

Rubicon. Very similar in Rubicon. shape and color to Chantenay. Pkt. 10 cts., oz. 15 cts., $1 / 4$ lb. 35 cts., 1 lb. \$1.25. Postpaid.

Danvers. Although on ly Danvers. half - long, this orange carrot will produce as great a weight per acre as any other sort, and it is therefore useful for stock as well as for the table. The flesh is closely grained, with little core, and the shape so smoothly cylindrical that it makes a particularly attractive root. Pkt. 5 cts., oz. 10 cts., $1 / 4$ lb. 30 ets., 1 Ib. \$1.00. Postpaid.

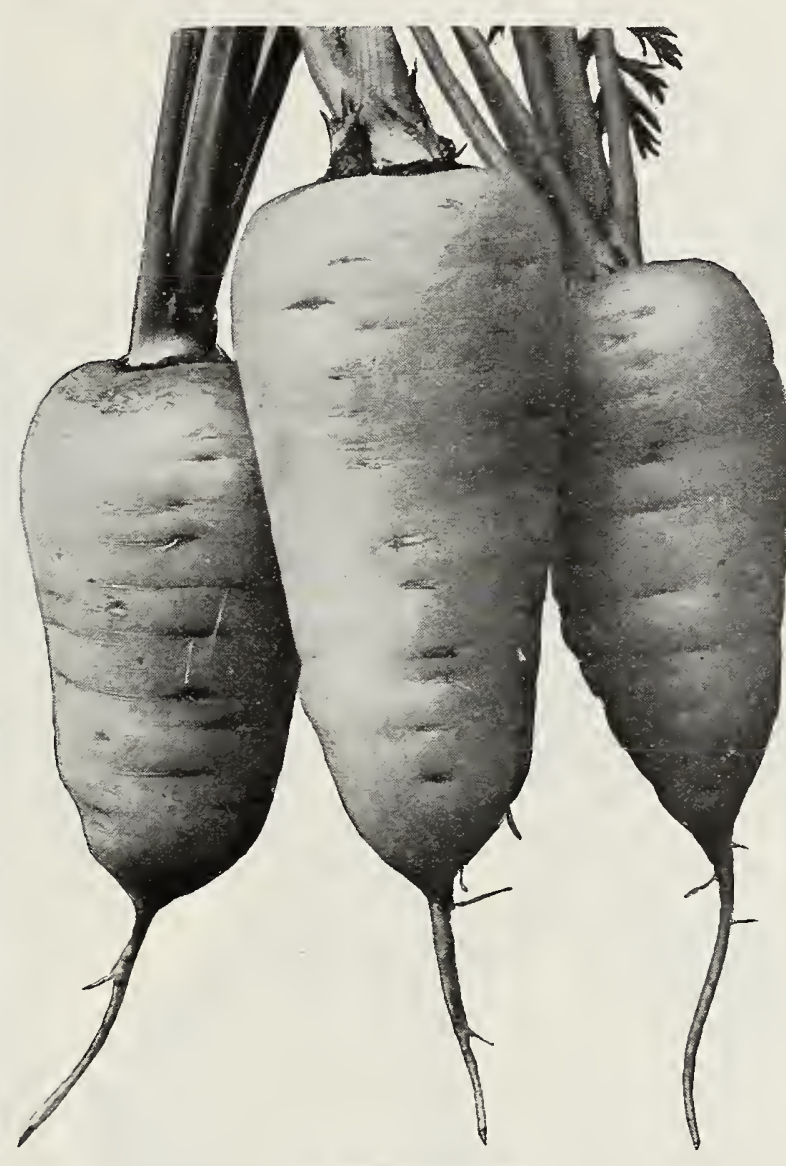

Chantenay Carrot
Ox h e a r t or Guerande. The Guerande strain carrot is intermediate between the Half-Long and the French Horn, and is entirely distinct in its characteristics. It is a thick oval in shape, having a diameter of from three or four inches at the neck, and is rich orange in color. On hard, stiff soil carrots of the stump-rooted class do much better than larger growing varieties, and are more easily dug when mature. Pkt. 10 cts., oz. 15 cts., $1 / 1 /$ lb. 35 cts., 1 lb., \$1.25. Postpaid.

St. Valery. Gardeners who vers Carrot are sure to be pleased with this, as it has the same fine quality and is of more attractive shape. It is about two-thirds the length of the Long Orange and is mucl more symmetrical, tapering sharply to a point. Pkt. 5 cts., oz. 10 cts., $1 / 4$ lb. 25 cts., 1 lb. 90 cts. Postpaid.

Long Orange. The standfor main crop, and available for table use as well as stock feeding. It grows to a large size, and when well cultivated in deep light soil will usually average 10 or 12 inches in length, with proportionate diameter. Pkt. 5 cts., oz. 10 cts., 1/4 lb. 25 cts., 1 lb. 90 cts. Postpaid.

White Belgian.

A very productive variety, which is grown exclusively for stock. Its large roots grow one-third out of the ground, the part covered being pure white. Oz. 10 ets., $1 / 41$ lb. 20 cts., 1 lb. 75 cts. Postpaid.

\section{A R D O O N}

(Cynara Cardunculus.)

CULTURE.-I ounce is sufficient for 100 feet of drill, 8 ounces will produce enough plants for an acre. Sow early in spring $1 / 4$ of an inch deep, in drills $2 \frac{1}{2}$ feet apart, and thin to 18 inches between the plants. Blanching is best done by hilling like celery, although the stalks will blanch if storcd in a dark cellar. Large Solid. The most desirable variety, as the leaves are almost free from spines; the stems, after being blanched
like celery, are useful for stews, soups and salads. Pkt. 10 cts., oz. $\mathbf{2 5}$ cts., 1/1 lb. 75 cts., lb. $\$ 2.75$. Postpaid.

Remember we deliver free at catalogue prices-except where noted. Write for special prices in large quantities. 
G A U L IF L OW E R

(Brassica Oleracea Botrytis.)

Cho-fleur. Biumenkohl. Cavoloflore. Coliflor.

CULTURE.-I ounce is sufficient for 100 feet of drill; 4 ounces will produce enough plants to set an acre. Sow out of doors the last of September in a carefully-prepared bed $1 / 4$ of an inch deep, rolling or treading the surface if the weather be dry, and transplant into cold frames for protection during the winter, or in a gentle hot-bed in November, transplanted into cold frames, and set in the field early in April, in rows $2 \frac{1}{2}$ feet apart, allowing 18 inches between the plants. While in the frames the plants must be kept free from slugs, and if they appear, the soil and plants should receive a light sprinkling of lime. For a late crop, sow from the 15th of April to the 1st of July, transplanting in the same way as winter cabbage, and giving, if possible, rich, moist bottom land. The beds must be well weeded, and too much attention cannot be given to watering in dry seasons, as the leaves will droop, and the plant suffer seriously if this is neglected. The heads are blanched by drawing the leaves together and tying closely with raffia or strips of other soft material. They must always be cut before the "curd" begins to split and open into branches.

White Bouquet A few days later than Snowball, this selected market gardeners' is possible to produce. The superiority which we claim for it is particularly shown in its earliness, certainty of heading, splendid quality and well shaped heads of snowy whiteness. For an extra early variety the heads are quite large, although on account of a very compact habit of growth the plants may be set very closely together and this characteristic renders it especially valuable for forcing under sash if so desired. The stalk is so short that it is very slightly exposed, and the upright growth of outside leaves affords a great protection to the heart. In favorable seasons we have seen grown in this section specimens the equal of any produced on Long Island. Pkt. 25 and 50 cts., oz. \$3.00, 2 ozs. \$5.00, 1/1 lb. \$9.00, 1 lb. \$35.00.

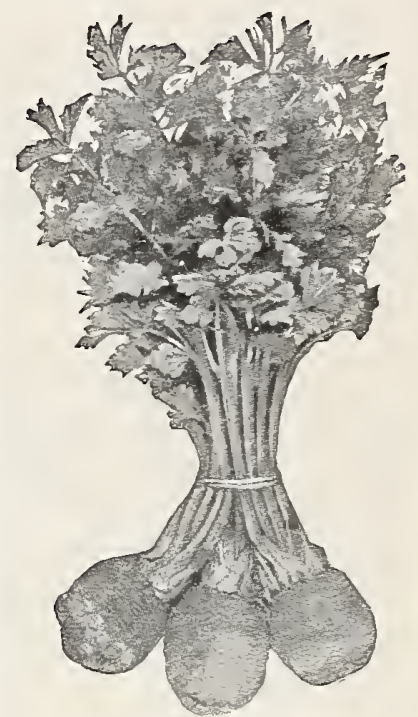

Giant Prague Celeriac Postpaid.

Snowball. Probably the earliest variety, and like our Thoroughbred White Bouquet, is as equally celebrated. We recOr ommend both selections unreservedly, but find that in different sections preference is often shown for one or the other, owing to the effects of various soils and climates. The Snowball is characterized by symmetry of head, beauti-

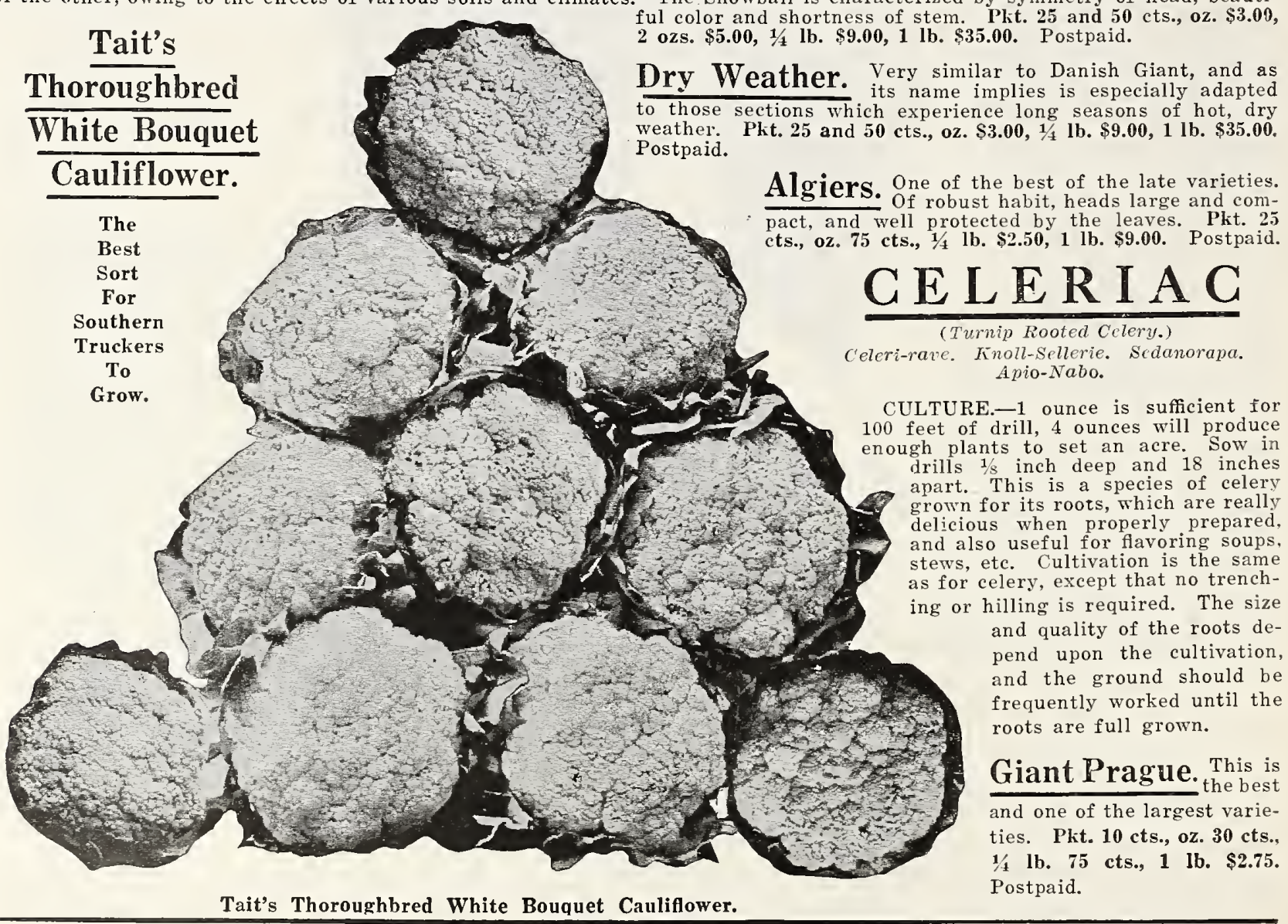

Remember we deliver free at catalogue prices-except where noted. Write for special prices in large quantities. 


\section{E L E R Y}

(Apium Graveoiens.)

Celeri. Sellerie. Sedano. Apio.

CULTURE.-1 ounce is sufficient for 100 feet of drill; 4 ounces will produce enough plants to set an acre. The cultivation of celery in a hot climate is attended with some difficulty, but while Southern celery is rarely so large as that grown in colder sections, it is not surpassed by any in firmness of grain and delicacy of flavor. Sow from April to July not more than $1 / 8$ of an inch deep in a moist place, lightly rolling or pressing the surface after sowing to facilitate germination. If the seed bed is very finely pulverized, the seeds may be simply scattered over the surface and then pressed into the soil with the hand or back of spade, the whole bed then covered with old bags until the seeds germinate. Our celery seed will never fail to grow when handled in that way. When the plants are 4 or 5 inches high, transplant into trenches 4 feet apart, leaving 6 to 9 inches between them. To have stocky plants it is advisable to shear off the tops of the plants in the bed once or twice before setting out. For the long-stalk varieties dig the trenches a foot deep and put 4 or 5 inches of thoroughly rotten manure on the bottom, covering that again with 3 inches of good soil. For the Dwarf and Half-Dwarf kinds the trenches may be only 9 inches deep, and a little closer together. As the plants grow, draw the earth up gradually to keep the leaf stalks together, and water freely in dry weather. Finish hilling up in the fall, to blanch for use, but always avoid working the ground when it or the plants are wet. In many places the blanching is now done by means of boards laid against the rows.

\section{Early Self-Blanching Varieties}

Wonderful. A new type of Golden Self-Blanching with wider leaves and thicker stems. In our judgment a great improve-

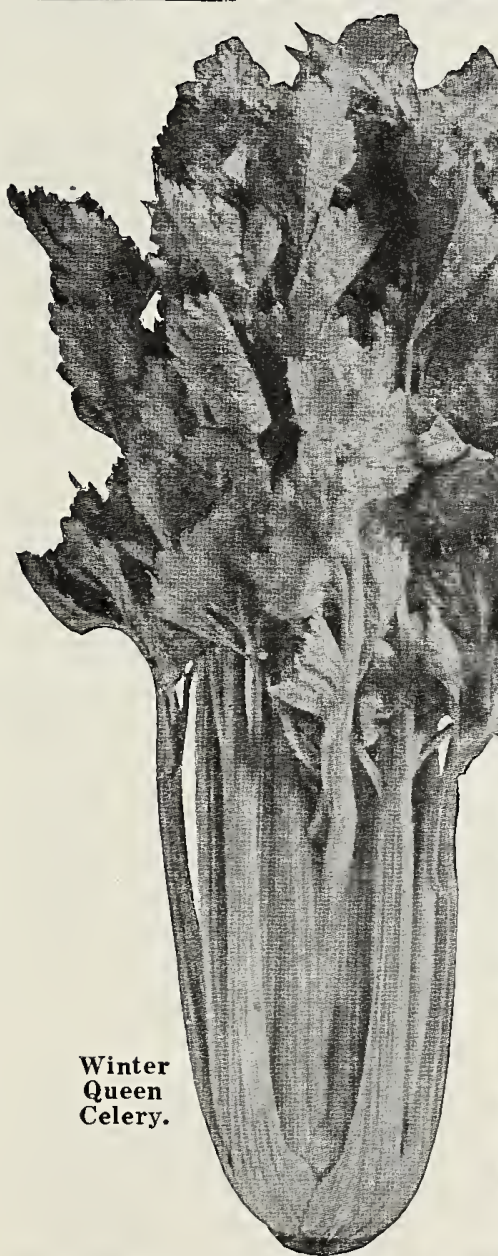
ment over other yellow va-
rieties. It is somewhat earrieties. It is somewhat earSelf-Blanching and is more easily blanched to a clear creamy white. It has a very full heart of beautiful yellow color. It is a vigorous grower resistant to disease and splendid for either home or market. Pkt. 15 ct s., oz. $\$ 1.00,1 / 4$ lb. $\$ 3.00$, 1 lb. $\$ 10.00$. Postpaid.

\section{Improved Gol- de $\mathrm{n} \mathrm{Se} \mathrm{If} \mathrm{-}$} Blanching.

This grand variety does not require as much labor as is necessary for the blanching of ordinary kinds, and it is very beautiful when matured, the heart being large, solid and of a rich golden color and of the finest quality. Our Market Gardener's strain is grown in France from the originator's stock and we strongly recommend it to those who grow celery either for home or market. Pkt. 15 cts., oz. 75 cts., $1 / 4$ lb. $\$ 2.25,1$ lb. $\$ 7.00$. Postpaid.

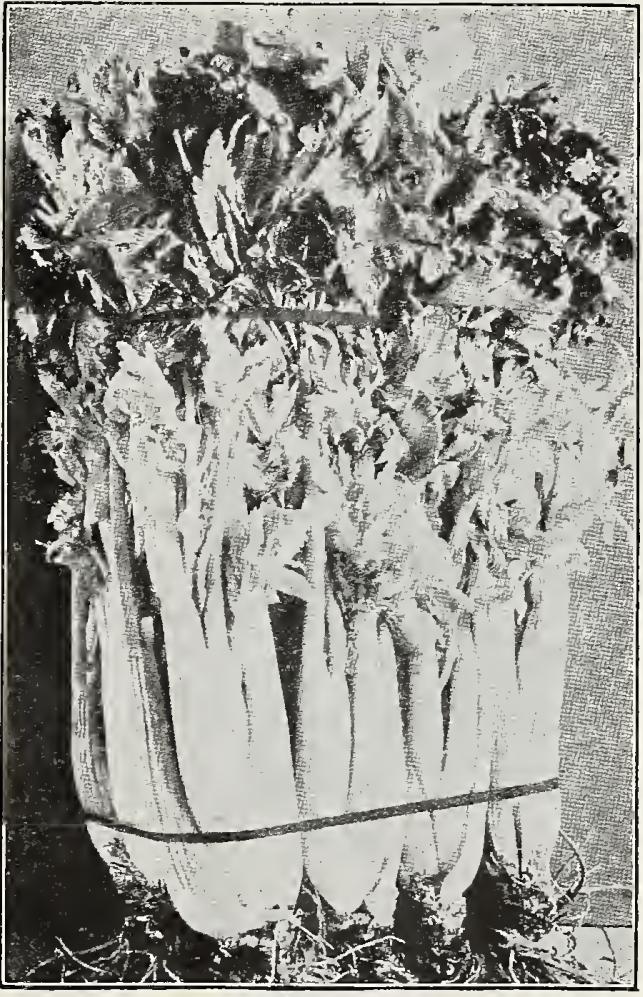

Wonderful Celery.

Golden Self-Blanching (American Grown). Pkt. 10 cts., oz. 50 ets., $1 / 1$ lb. $\$ 1.50,1$ lb. $\$ 5.00$. Postpaid.

\section{Winter Keeping Varieties}

Easy Blanching. One of the most desirable of the half dwarf varieties for presents an attractive appearance when bunched. It is disease resistant, a good keeper. easy to blanch, with thick stalks of delicious flavor, that have nearly double the heart of other varieties. Pkt. 10 cts., oz. 50 cts., $1 / 4$ lb. $\$ 1.50,1$ lb. $\$ 5.00$. Postpaid.

Winter Queen. An exceptionally fine winter variety and especially recommedium height, solid, crisp and of good flavor. Pkt. 10 cts., $0 z .30$ cts., 1/4 lb. 90 cts., 1 Ib. $\$ 3.00$. Postpaid.

Giant Pascal. A deep green selection from the Golden Self-Blanching, and especially adapted to Southern cultiva$1 / 4$ lb. 60 cts.. 1 lb. $\$ 2.00$. Postpaid.

Soup Celery. old Celery seed used for flavoring purposes only. Oz. 5 cts., 1/4 lb. 20 cts., 1 lb. 75 cts. Postpaid.

Remember we deliver free at catalogue prices-except where noted. Write for special prices in large quantities. 


\section{H I C O R Y}

(Chicorium.)

Chicoree Sauvage. Chicorienwurzel. Cicoria Selvatica. Achicoria.

CULTURE.- 1 ounce is sufficient for 100 feet of drill; 2 to 5 pounds for an acre. Sow from April to July $1 / 2$ an inch deep in any light, rich loam, in drills 18 inches apart, and when the plants are large enough thin to 6 inches in the row. Witloof or French Endive is cultivated in the same way as ordinary Endive until the stalks are tall enough to be handled like celery. It blanches readily, and is a most delicious salad, very salable in all the great markets. For forcing, the roots should be lifted in the fall, cutting off the leaves, and stored in earth or some cool place until ready to force. In forcing, the parsnip-shaped roots should be placed upright 3 inches apart in trenches 18 inches deep, and about the same distance apart, leaving the top of the roots 9 inches below the level of the trench. If a quick growth is desired mulch with fresh manure level with the ground.

Witloof A winter salad, also known as French Endive. Most delicious when served with French Withessing and eaten like Lettuce. It can alsc be used as a boiled vegetable prepared the same way as Cauliflower. Pkt. 10 cts., oz. 20 cts., $1 / 1$ lb. 70 cts., 1 lb. $\$ 2.00$. Postpaid.

Large Rooted. The roots of this variety when dried, roasted and ground are utilized as a substitute for coffee. Pkt. $10 \mathrm{cts.}$ oz. $20 \mathrm{cts.}, 1 / 1 \mathrm{lb}$ l. $70 \mathrm{cts} ., 1 \mathrm{lb} . \$ 2.00$. Postpaid.

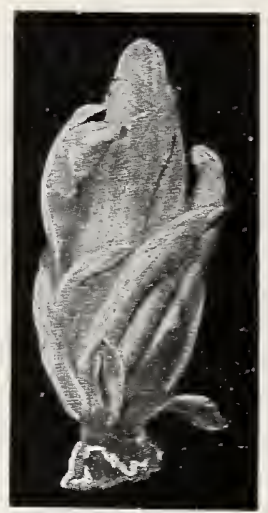

Witloof Chicory

\section{G H I V E S}

\section{(Allium Schoenoprasum.)}

CULTURE-1 ounce is sufficient for 100 feet of drill, 1 to 3 pounds for an acre. Sow in March or September in drills 1 ' inch deep and 18 inches wide, giving the same general culture as for onions. Chives are perennial onion-like plants perfectly hardy and especially valuable in the market because they are ready for use early in the spring. Only the leaves are used, these being cut as freely as desired, since fresh ones appear quickly after every cutıing. Pkt. 10 cts., oz. 50 cts., 1/4 lb. $\$ 1.50$, 1 lb. \$5.00. Postpaid. We can also supply the roots in March and April at 50 cts. per clump, or $\$ 4.50$ per dozen. Postpaid.

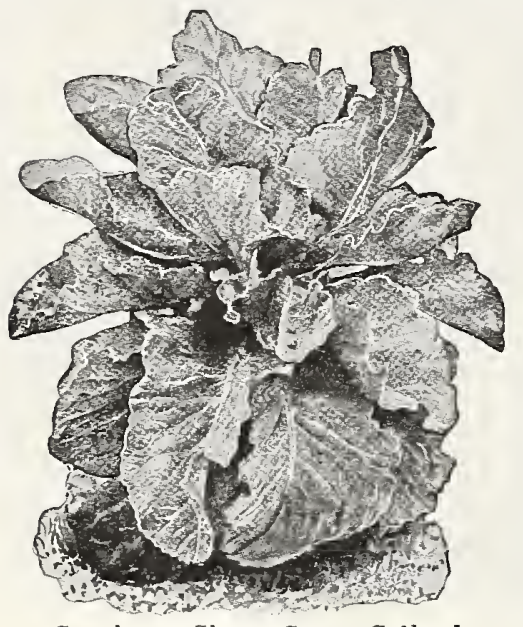

Southern Short Stem Collard

\section{COLLA R D S}

(Brassica Oleracea Vars.)

Chou cabu. Blatterkohl. Collards. Cabu.

CULTURE.-1 ounce is sufficient for 100 feet of drill, 4 ounces will produce enough plants to set an acre. Sow from March to July as directed for cabbage, either in beds to be transplanted when large enough, or in rows where the plants are to stand. The rows should be 3 feet apart, with the plants set 24 to 30 inches in the row.

Southern Short Stem. A great favorite in the South, where it will live where it would be almost impossible to raise cabbage heads. Though quite coarse in flavor until touched by frost, it then becomes peculiarly sweet and tender. The crop is usually quite profitable. Pkt. 5 cts., oz. 10 cts., $1 / 1$ lb. 25 cts., 1 lb. 90 cts. Postpaid.

White Cabbage. This popular Collard forms a sort of head, and is more atSouthern Short Stem, tractive in appearance as well as of finer quality than the Pkt. 5 cts., oz. 10 cts., $1 / 4$ lb. 25 cts., 1 lb. 90 cts. Postpaid.

\section{O R N \\ (Zea Mays.) \\ Mais. Mais. Mais. Maiz.}

A pint weighs about three-quarters of a pound. A bushel of sweet corn weighs about 56 lbs., and a bushel of sugar corn about 40 lbs.

N. B.-Seed corn being liable to heat when left in bulk, we strongly advise that it be spread or kept well ventilated until wanted for planting.

CULTURE.- $1 / 2$ pint of corn is sufficient for a row of 100 feet, 6 to 10 quarts being allowed to the acre. Plant from April to July, 1 inch deep in rows 3 feet apart, leaving 18 inches between the plants. The small extra early varieties may be planted as close as 2 feet if the ground has been heavily fertilized. If many side shoots appear, break them off and keep the soil well cultivated around the stalks. As sugar corns are very sensitive to cold and damp weather, they should never be planted until the ground has become thoroughly warm. In shipping green corn, care must be exercised to avoid using too large a package, as it heats very easily. Ventilated baskets or crates holding a bushel make the best package.

Remember we deliver free at catalogue prices-except where noted. Write for special prices in large quantities. 


\section{EXTRA EARLY CORNS}

(Sweet Corns.)

Tait's Thoroughbred Fifty Day. This new variety will prove for those extra early variety. It is nearly as early as Adam's Extra Early, but the ears will average much larger, usually growing from 8 to 10 inches in length and of good quality. The cob is of medium size with straight rows of grains that fill out to the end of the cob. Pkt. 10 ct s., $1 / 2$ lb. 20 cts., 1 lb. 35 cts., 2 lbs. 65 cts., 4 lbs. $\$ 1.20,10$ lbs. $\$ 2.40$. Postpaid.

Adam's Extra Early. A well known stock, which is largely grown by SouthAdam's Extra Larly. ern shippers because it is the earliest corn in cultivation. The ears, although very small and of indifferent quality, can usually be cut about six weeks after the date of planting. A crop of this corn cannot be made upon land which is not strong and well fertilized. Pkt. $10 \mathrm{cts.}, 1 / 2 \mathrm{lb} .20 \mathrm{cts}$., $1 \mathrm{lb} .30 \mathrm{cts} ., 2 \mathrm{lbs} .50 \mathrm{cts} ., 4 \mathrm{lbs}$. 90 cts., 10 lbs. $\$ 1.75$. Postpaid.

Bland's Extra Early. About the same earliness as Extra Early Adams, but sections for early market. Pkt. 10 cts., $1 / 2$ lb. 20 cts., 1 lb. 30 cts., 2 lbs. 50 cts., 4 lbs. 90 cts., $10 \mathrm{lbs}$. $\$ 1.75$. Postpaid.

(Sugar Corns.)

Premo. Being practically as hardy as the Extra Early Adams, of better quality and Premo. with much larger ears, this should prove valuable to our Southern customers who grow corn for shipment. Pkt. 10 cts., $1 / 2$ lb. 15 cts., 1 lb. 25 cts., 2 lbs. 45 cts., 4 lbs. 80 cts., 10 lbs. $\$ 1.75$. Postpaid. Golden Bantam. You will find our stock of this extra early yellow sugar corn though small in stalk and ear, it is still a favorite with many gardeners on account of its sweetness. Pkt. 10 cts.s $1 / 2$ lb. 20 cts., 1 lb. 35 cts., 2 lbs. 65 cts., 4 lbs. $\$ 1.20,10$ lbs. $\$ 2.40$. Postpaid.

Golden Giant. Those who like Golden Bantam will be delighted with this variety Golden Giant. as it has all the good points of the former, but the ear is much larger and the shuck covers the tip completely, protecting the ear from worms. Pkt. 10 cts., $1 / 2$ lb. 20 cts., 1 lb. 35 cts., 2 lbs. 65 cts., 4 lbs. $\$ 1.20,10$ lbs. $\$ 2.40$. Postpaid.

\section{E A R L Y}

(Sweet Corns.)

Tait's Thoroughbred Early Morn. A variety that is crowding Adam's Early out of cultivation. It is about the cob is of medium size with straight rows of grain that fill out to the end of the cob and seeds planted in April will mature ears in about sixty days. The stalks grow about five feet in height, producing two large ears that are generally not more than $2 \frac{1}{2}$ feet from the ground. All growers of "roasting ears" for market should give it a trial. Pkt. 10 cts., 1/2 lb. 20 cts., 1 lb. 35 cts., 2 lbs, 65 cts., 4 lbs. $\$ 1.20,10$ lbs. $\$ 2.40$. Postpaid.

Tait's Thoroughbred Norfolk Market Our wonderful and now famous lutionized the growing of early sweet corn. If unsalable in the green state the old kinds were worthless, but Tait's Norfolk Market is valuable when matured. Unlike the early varieties which have heretofore been considered standard, it is a really handsome corn, and valuable aside from its availability for "roasting ears," the ears attaining an average length of over ten inches, with about sixteen rows to the ear. When in a green state the grains are just a nice size, very plump, milky, of the best quality, many people preferring it to the sugar varieties. Letters received from points all over the country show that it is popular in all markets, for consumers soon discover that its quality accords fully with its prepossessing appearance. Pkt. 10 cts., $1 / 2$ lb. 20 cts., 1 lb. 30 cts., 2 lbs. 50 cts., 4 lbs. 90 cts., 10 lbs. $\$ 1.75$. Postpaid. 
Adam's Early. Ten days later than Adams, but somewhat larger, and the leading early corn up to the introduction of Tait's Early Morn and Tait's Norfolk Market. Pkt. 10 cts., $1 / 2$ lb. 20 cts., 1 lb. 30 cts., 2 lbs. 50 ets., 4 lbs. 90 cts., 10 lbs. \$1.75. Postpaid.

Silver King. An early white dent Nilver Ming. corn that can be used for early "roasting ears", or as an early field crop. It is very similar to Truckers, Favorite. Pkt. 10 cts., $1 / 2$ lb. 15 cts., 1 lb. 25 cts., 2 lbs., 45 cts., 4 lbs. 80 cts., 10 lbs. $\$ 1.60$. Postpaid.

Truckers' Favorite. A selection Early White Dent, useful either for early roasting ears or for early dry corn. For roasting ears not near as good as Norfolk Market. Pkt. 10 cts., 1/2 lb. 15 cts., 1 lb. 25 cts., 2 lbs. 45 ets., 4 lbs. 80 cts., 10 lbs. $\$ 1.60$. Postpaid.

\section{E A R L Y}

(Sugar Corns.)

\section{Tait's Thoroughbred Early}

Giant. Under proper cultivation, the are upwards of eight inches in length and have no less than ten rows, the grains being unusually deep. The cob is white, and the ear tapers so little that the well-rounded point is nearly as thick as the bottom. The flavor is as good as any except perhaps the Country Gentlemen; it remains a long time in the milky state. Pkt. 10 ets., $1 / 2$ lb. 20 cts., 1 lb. 35 ets., 2 lbs. 65 cts., 4 lbs. $\$ 1.20,10$ lbs. $\$ 2.40$. Postpaid.

Howling Mob. This variety is very itan, only a few days later than the Extra Earlies, and is of good quality. The stalk grows about five feet high, and usually will produce two medium-size ears, with ten or twelve rows of pearly white grains. Pkt. 10 cts., $1 / 2$ lb. 20 cts., 1 lb. 35 cts., 2 lbs. 65 cts., 4 lbs. $\$ 1.20,10$ lbs. $\$ 2.40$. Postpaid.

Golden Cream. An early yellow vafrom crossing Golden Bantam and the Country Gentleman, and is sometimes called "Yellow Country Gentleman," having the irregular grains of the latter. The stalks grow about four and one-half feet high, bearing two or more ears about five inches in length. Pkt. 10 cts., $1 / 2$ lb. 20 cts., 1 lb. 35 cts., 2 lbs. 65 ets., 4 lbs. $\$ 1.20$, 10 lbs. \$2.40. Postpaid.

\section{$\frac{\mathrm{L} A \mathrm{~A} \mathrm{E}}{\text { (Sugar Corns.) }}$}

White Evergreen. The universal reputation of will ensure a welcome for this greatly improved strain, the cob and grain of which are both pure and white; with all the sweetness and tenderness characteristic of the old stock. Pkt. 10 ets., $1 / 2$ lb. 20 cts., 1 lb. 35 cts., 2 lbs. 65 ets., 4 lbs. $\$ 1.20,10$ lbs. $\$ 2.40$. Postpaid.

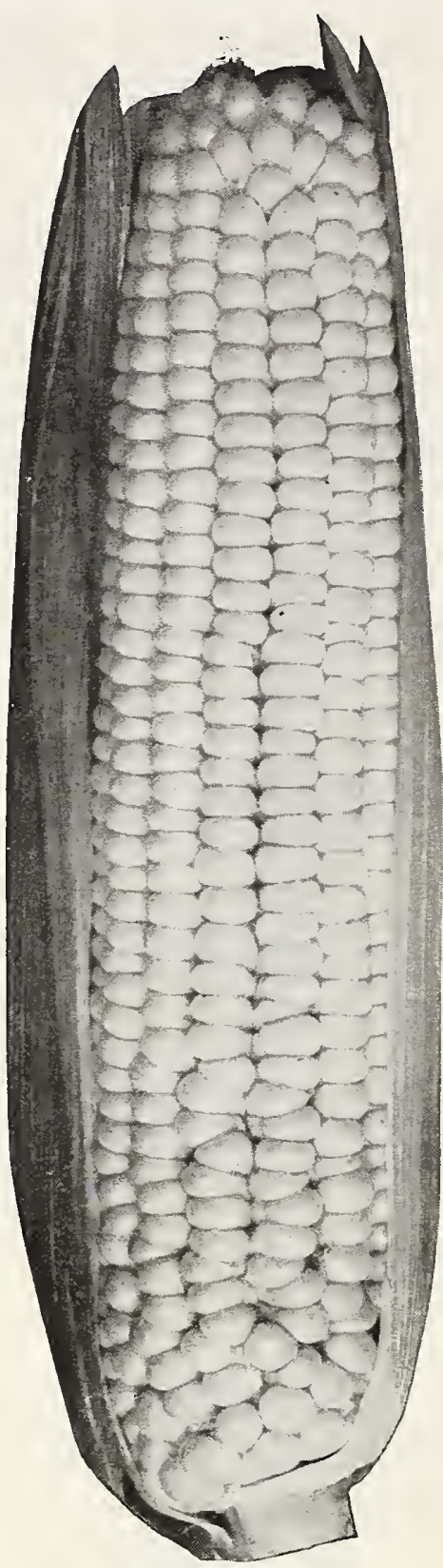

Tait's Thoroughbred Giant Sugar Corn.
Stowell's Evergreen. For the main was long considered the most valuable variety of sugar corn, as it remains green for a long time, and is usually more exempt from worms in the ear than most sorts in the South. The grain is deep and exceptionally well flavored, but the introduction of White Evergreen has put it in second place. Pkt. 10 ets., 1/2 lb. 20 cts., 1 lb. 35 cts., 2 lbs. 65 cts., 4 lbs. $\$ 1.20,10$ lbs. $\$ 2.40$. Postpaid.

Country Gentleman. All who Country Gentleman. have grown the Country Gentleman Corn agree in pronouncing it one of the very best sorts, and almost all gardeners use it for the late crop of table corn. It is of particularly fine flavor, very milky and tender and has an unusually small cob. The ears average eight inches or more in length, and a stalk will sometimes produce as many as four full-sized ears. Pkt. 10 cts., $1 / 2$ lb. 20 cts., 1 lb. 35 cts., 2 lbs. 65 c., 4 lbs. $\$ 1.20,10$ Ibs. \$2.40. Postpaid.

Black Mexican. The grains of this Black INexican. c orn are black when matured, but a beautiful white when young. It is very sweet, and has won great favor in many parts of the country, although it is less desirable than many other sorts. Pkt. 10 cts., 1/2 lb. 20 cts., 1 lb. 35 cts., 2 lbs. 65 cts., 4 lbs. $\$ 1.20$, 10 lbs. \$2.40. Postpaid.

Late Mammoth. The largest sugar have, corn which we nd strongly recommended on acbut it is very late. Pkt 10 cts ctiveness, cts., 1 lb. 35 cts., 2 lbs. 65 cts., 4 lbs. $\$ 1.20$, 10 lbs. $\$ 2.40$. Postpaid.

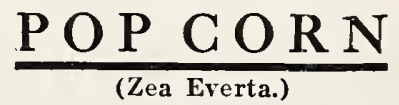

White Rice. This variety is regarded White Rice. as the best pop-corn for commercial use, as it yields more than any other, and is all that could be desired for popping. The fodder makes good green food, and it is sometimes planted exclusively for that purpose. Lb. 25 cts. Postpaid.

Ruby. There is little, if any, difference between this and the ordinary White Rice except as to color, which is a beautiful red, and even this distinction disappears after popping. Lb. 25 cts. Postpaid.

Queen's Golden. Bright yellow in this pops to snowy white and is of the best quality. The ears are very large for popcorn and are really quite decorative. Lb. 25 cts. Postpaid.
Remember we deliver free at catalogue prices-except where noted. Write for special prices in large quantities.

White Peàrl. This beautiful round grain, from which Pe name of Pearl is derived, makes this much more easily shelled variety than White Rice and for small growers it will be found excellent. Lb. 25 cts. Postpaid.

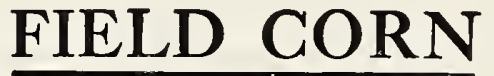

(See Index.) 


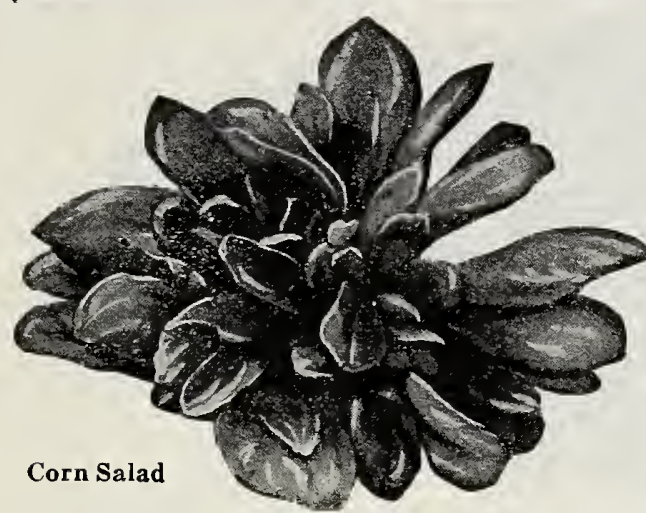

C R E S S

(Lepidium Sativum.)

Cresson Alenois. Garten-Kresse. Agretto. Berro.

CULTURE.-1 ounce will sow 100 feet of drill, 11/2 pounds will sow an acre. As curled cress soon runs to seed and then becomes useless, it is well to sow at intervals of 10 or 12 days from March to October, $1 / 4$ of an inch deep in drills 18 inches apart, allowing 6 to 9 inches between the plants. To secure the best germination of the seed, press the earth over them firmly with spade or light roller.

Curled. This variety of Pepper Grass is much liked as a Uuried. component of salads on account of its characteristic flavor. Pkt. 5 cts., oz. 10 cts., $1 / 4$ lb. 30 cts., 1 lb. $\$ 1.00$. Postpaid.

Upland. A perennial variety resembling Water Cress,

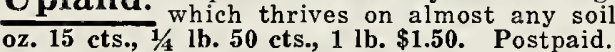

\section{GORN SALAD or FETTICUS}

( Valerianella Olitoria.)

Mache. Feldsalat. Valeriana. Canonigos.

CULTURE.-2 ounces are sufficient for 100 feet of drill, 3 to 5 pounds will sow an acre. If wanted for winter and early spring salad, the seed should be sown in drills $1 / 2$ inch deep in September, or it may be sown in April, giving in general the same treatment as spinach. If sown early in Large Seeded. A quick-growing salad, which should be in every garden. In the South it is perfectly hardy, growaxcept freezing weather. Properly served with a ell-made dressing, it is far superior in flavor to the salads most in general use. Pkt. 5 cts., oz. 10 cts., $1 / 4$ lb. 25 cts., 1 lb. 90 cts. Postpaid.

\section{W A TER CR ESS}

(Nasturtium Officinale.)

Cresson de Fontaine. Brunnen-Kresse. Nasturizio Aquaiico. Berro.

CULTURE.-1 ounce will produce about 3,000 plants. It does best sown in the early spring in shallow water, beside a running stream, but may be readily grown in any moist soil or in a damp hot bed if not allowed to be too warm. Water Cress will often grow luxuriantly in al ordinary ditch, provided the soil never becomes dry and baked.

Water Cress. This delicious piquant salad is univerWater Cress. sally estecmed, and would be more commonly grown but for a general impression that it succeeds only in a brook. Pkt. 10 cts., oz. 30 cts., $1 / 4$ lb. $\$ 1.00,111$. \$3.75. Pcstpaid.

\section{U C U M B E R}

(Cucumis Sativus.)

Concombre. Gurken. Cetriolo. Pepino.

CULTURE.-1 ounce is sufficient for 100 feet of drill, or 50 hills; 2 to 4 pounds are required for an acre in hills, or from 10 to 15 pounds if sown in drills. Cucumbers may be sown from April until August, but for the main crop the seed should be sown in the open ground as soon as danger of frost is past. While the usual way of sowing is to put the seed in hills, 4 by 6 feet, the method employed around Norfolk is to drill the seed $3 / 4$ of an inch deep in rows 6 feet apart, between garden peas, which act as a shelter, and thinned to 3 or 4 plants in the hill. When drilled, 2 or more sowings are made, and thinned to 1 plant every 12 inches apart. The young plants are often attacked by insects, and should not be thinned out until they are large enough to be safe. The cucumbers should be gathered as fast as they are produced, whether they are wanted or not, as the vines will otherwise cease to bear. As cucumbers are very liable to a certain disease known as Cucumber Blight, the vines should be kept sprayed with Bordeaux mixture from the time they begin to run.

\section{EARLY VARIETIES}

\section{Tait's Thoroughbred}

Climax. For Florida and Cections that like a cucumber of medium length, this variety is very popular. It has many desirable qualities. It is extra early, slender, productive, and of a beautiful dark green color. It stays green a long time after pulling. Pkt. 10 cts., oz. 15 cts., 4 ozs. 50 ets., 1 lb. $\$ 1.50$. Postpaid.

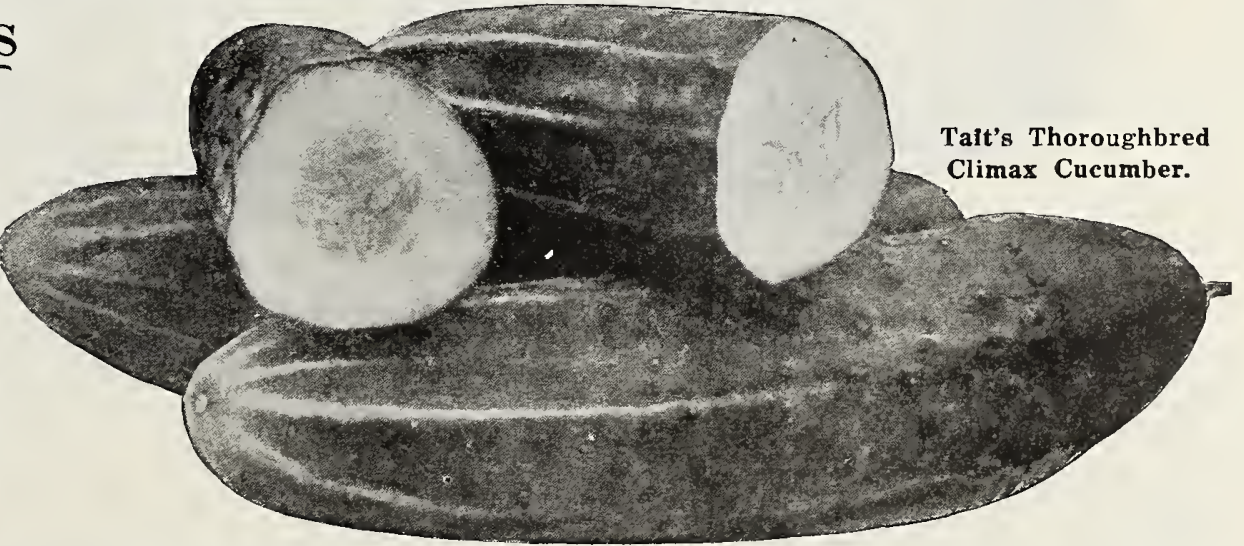

Remember we deliver free at catalogue prices-except where noted. Write for special prices in large quantities. 


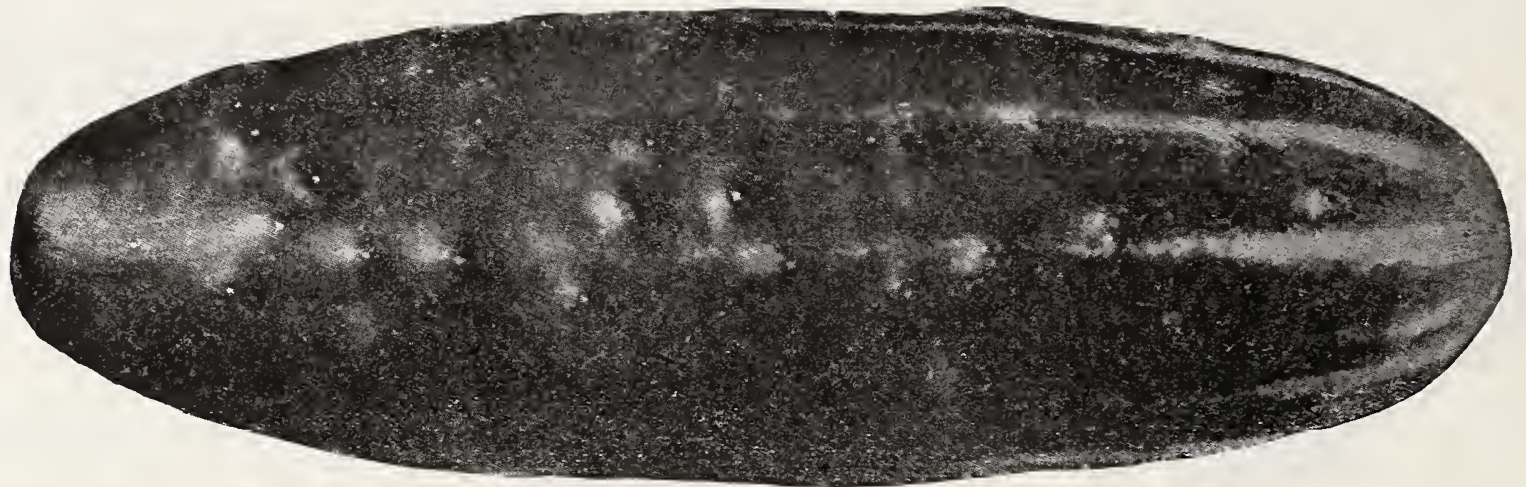

Tait's Thoroughbred Prosperity Cucumber.

Tait's Thoroughbred None Such. The new variety, under good eultivation, is of very deep color, and appears market value, there are many who say there is nothing like it-hence we have named it "None Such." This is really a remarkable Cucumber, very early, nearly perfect in shape, of splendid quality, and just the right length for market. We have seen the fruit of the None Such and Prosperity hold its dark green color three weeks after being pulled. We consider these two sorts the best for southern truckers. Pkt. $10 \mathrm{cts.,}$ oz. $15 \mathrm{cts} ., 1 / 4 \mathrm{lb} .50 \mathrm{cts} ., 1 \mathrm{lb} . \$ 1.50$. Postpaid. (See illustration on front page.)

Tait's Thoroughbred Prosperity. Cucumber growers who were fortunate in having this variety the past two

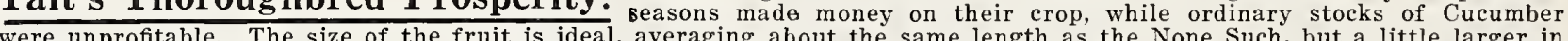
diameter. The color is a rich dark green, which is retained for two or three weeks after pulling, making it most desirable for long distance shipping. It is of exceptionally fine quality, and all growers of Cucumbers should certainly plant some of this sort, as it is, without doubt, one of the best varieties we have ever seen. Pkt. $10 \mathrm{cts}$., oz. 15 cts., 1/4 lb. $50 \mathrm{cts}$., $1 \mathrm{lb}$. $\$ 1.50$. Postpaid. See illustration above.

Davis Perfect. The darkest green of all the White Spine varieties, but rather late, a shy bearer, producing quite a Davis Perfect. percentage of misshapen fruits. Pkt. 10 cts., oz. 15 cts., $1 / 4$ lb. 40 cts., 1 lb. $\$ 1.35$. Postpaid.

Early Fortune. A popular variety and a good shipping sort. It is of good length, shape and color, and a favorite Pith many growers. Pkt. 10 cts., oz. 15 cts., 1/4 lb. 40 cts., $1 \mathrm{lb}$. $\$ 1.35$. Postpaid.

Perfected Arlington. This is a forcing strain selected out of the well-known Arlington White Spine. It is extra Perfected Arlington. early, good sized, of splendid color, and quite prolific. Pkt. 5 cts., oz. 10 cts., 1/4 lb. 30 cts., 1. \$1.00. Postpaid. See illustration below.

Klondike. A medium early cucumber, of an attractive shape. It retains its dark green color through long shipments Klondike. and is a favorite with some growers in the extreme South, but less desirable than None Such or Prosperity, which are just as dark and better cucumbers. Pkt. 5 cts., oz. $10 \mathrm{cts.}$ 1//4 lb. 30 cts., 1 lb. $\$ 1.00$. Postpaid.

Japanese Climbing. In small gardens where space is limited this will be useful, as it can be grown on poles or Japanese Climbing. trellis. The fruit is quite long, of dark green color, excellent quality and sets its fruit from early summer until frost. Plkt. 10 cts., oz. 15 cts., $1 / 4 \mathrm{lb} .40$ cts., $1 \mathrm{lb}$. 1.50 . Postpaid.

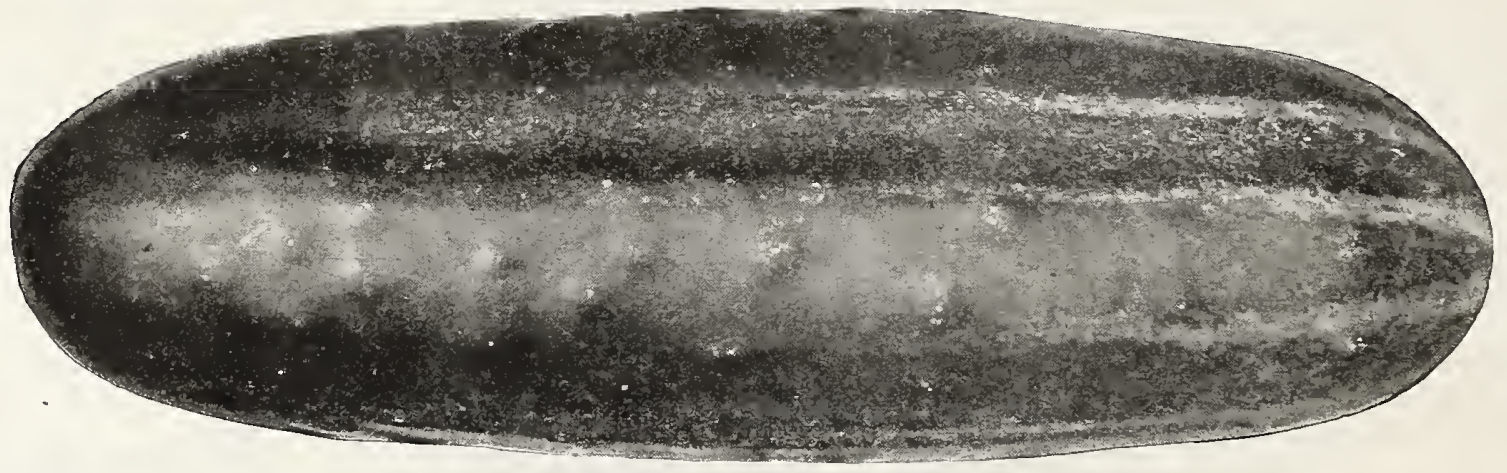

Perfected Arlington Cucumber.

\section{P I G K L I N G VAR IE TIES}

Cool and Crisp. This agreeably suggestive name has been given to a cucumber which is of great value in the fampickling. The flesh is ily garden, as it is extra early, well colored, a continuous bearer, and equally good for slicing or London Long Green. An old favorite of good shape, length and color, but late. It is firm-fleshed, crisp, with few London Long Green. seeds, and makes good pickles. Pkt. $10 \mathrm{cts.,}$ oz. $15 \mathrm{cts.,} 1 / 1 \mathrm{lb}$ l. $35 \mathrm{cts}$., $1 \mathrm{lb}$. \$1.35. Postpaid. Gherkin. Sometimes called Burr Cucumber and grown exclusively for pickles. Pkt. 10 cts., oz. 20 cts., $1 / 2 \mathrm{lb} .60$ cts.,

Remember we deliver free at catalogue prices-except where noted. Write for special prices in large quantities. 


\section{DANDELION \\ ( T araxicum Dens-Leonis.) \\ Pissenlit. Lowenzahn. Dente di Leone. Diente de Leon.}

CULTURE.-1 ounce is sufficient for 100 feet of drill, 4 to 6 pounds for an acre. Although many persons in the South will be rather incredulous, the cultivated dandelion is one of the most wholesome and agreeable of salads. It is perennial, and can be cut very early in the spring, as the leaves are among the first to appear. Sow in July or August, $1 / 2$ inch deep, making the drills about 18 inches apart, leaving 9 to 12 inches between the plants. Cultivate well throughout the growing season, and do not attempt to cut at all until the following spring.

Tait's Thoroughbred Cabbaging. This greatly improved dandelion is now the favorite with French gardenLithe ers. The thick, fleshy leaves are of specially good flavor, blanching aimost naturally. Pkt. 15 cts., oz. 75 cts., $1 / 4$ lb. $\$ 2.00,1$ lb. $\$ 7.50$. Postpaid.

\section{E G G P L A N T}

(Solanum Melongena.)

Aubergine. Eierpflanze. Petronciano. Berengena.

CULTURE.-1 ounce is sufficient for 100 feet of drill, 6 ounces will usually produce enough plants to set an acre. As the seeds are not of vigorous germination and require much greater heat than is necessary or desirable for other plants, they should be carefully sown in a specially prepared hot-bed. Sow $1 / 4$ of an inch deep in February or early March and keep the sash on until the plants appear, after which air must be given on warm days, close attention being given them during the earliest stages, as the young plant is exceedingly delicate. When 2 or 3 inches high prick them out into small pots to induce stockiness, and, if possible, transplant again into a larger size, since with every transfer the plant gains strength. Our Norfolk growers use a basket about six inches square, without a bottom, made by folding a slat that comes for that purpose, so as to be easily removed when the plants are set in the field. While very cheap, these give admirable results. Do not risk setting out the plants in the open ground too early, as a single cold night will sometimes seriously check the growth and probably cause the first blossoms to drop. When the weather has turned permanently warm, set them in the field in rows 4 feet wide, leaving 3 feet between plants. The ground must be very heavily manured and earth kept well drawn up around the stems. Nothing is so attractive to the potato bug, and care must be taken while the plants are small to keep them picked off daily. Outdoor sowings should not be made before May.

Black Beauty. A splendid variety, popular along the entire coast, and espeBlack Beauty. cially valued on account of its earliness. The fruit is somewhat egg-shaped, and the color such a rich dark purple that the name of "Black Beauty" is quite justified. A very desirable sort for market, as it does not turn gray until really unfit for food. Pkt. 10 cts., oz. 60 cts., $1 / 4$ lb. $\$ 1.65,1$ lb. $\$ 6.00$. Postpaid.

Florida High Bush. About the same color as Tait's Perfection, but not Florida High Bush. as early. This variety is liked by market gardeners in the extreme South, especially Florida. It is very hardy, productive, and stands shipping well. Pkt. 10 cts., oz. 45 cts., $1 / 4$ lb. $\$ 1.35,1$ lb. $\$ 4.50$. Postpaid.

Tait's Thoroughbred Perfection. This superb strain, until the intro(ardetion of Black Beauty, was reest Egg Plant. The fruit is a regular oval, very smooth and rarely showing any tinge of yellow or red, the deep purple skin having almost the lustre of satin. Very productive. Pkt. 10 cts., oz. 45 cts., 1/4 lb. $\$ 1.35,1$ lb. $\$ 4.50$. Postpaid.

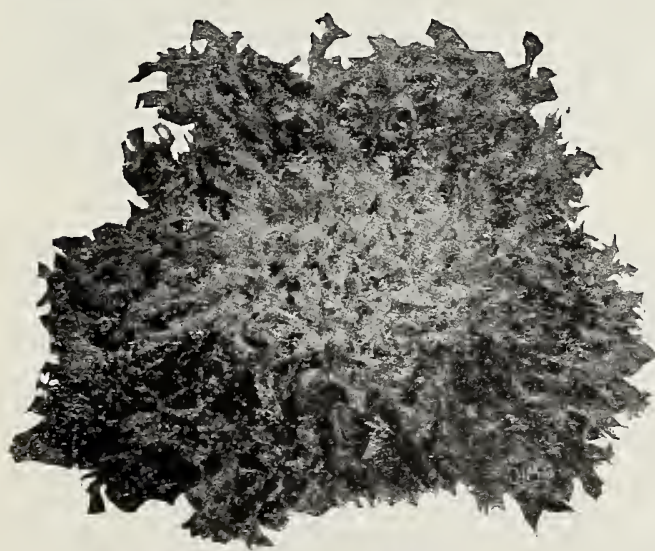

Green Curled Endive

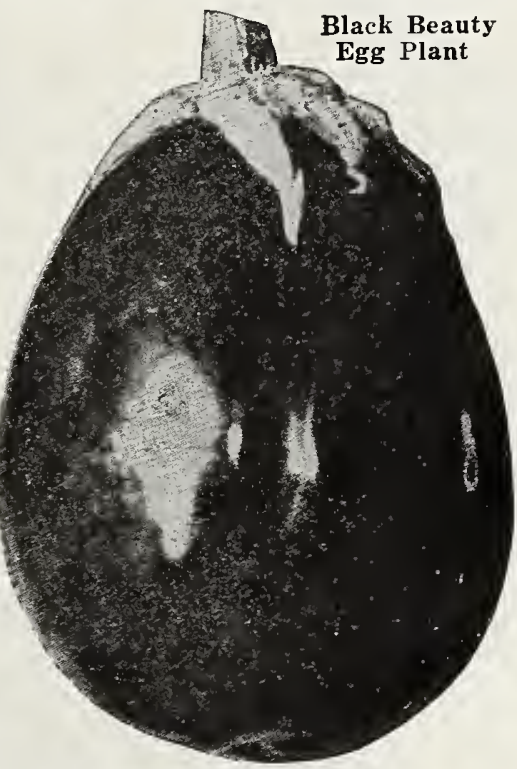

E N D I V E

(Chicorium Endivia.)

Chicoree Endivc. Endivien. Indivia. Endivia.

CULTURE.-1 ounce is sufficient for 100 feet of drill, 4 pounds will drill an acre, or 1 pound will produce enough plants to set out an acre. This plant is by no means appreciated in America, being altogether un known in many sections. It is a delicious salad, especially when served with lettuce, and universally regarded as very wholesome. Nothing is prettier than endive for garnishing, and we urge all our readers to introduce it in their gardens. Sow from April to September, $1 / 4$ of an inch deep in 18-inch rows, thinning the plants when about 2 inches high to 9 inches in the row. Cultivation about the same as for lettuce, except that the green sorts have to be blanched. When the leaves have grown to about 8 inches, gather them in the hand and tie together with soft twine or raffia, allowing 2 or 3 weeks for the blanching to be completed.

Broad Leaved Batavian. (Escarolle.) A very popular kind. (he inner leaves forming a sort of head, which blanches to a creamy white. It stands cold weather, can be used as a salad or cooked and served as spinach. Pkt. 10 cts., oz. 15 cts., $1 / 4$ lb. 35 cts., 1 lb. $\$ 1.25$. Postpaid.

Green Curled. The standard variety, very hardy, with deep green (hines that are finely crinkled and curled. Pkt. 10c. oz. 15 cts., 1/1 lb. 35 cts., 1 lb. $\$ 1.25$. Postpaid.

White Curled. Very similar to Green Curled, but with light green leaves that do not require tying up to blanch. Pkt. 10 cts., oz. 15 cts., $1 / 4$ lb. 35 cts., 1 lb. $\$ 1.25$. Postpaid. 


\section{FLORENCE FENNEL}

(Foeniculum Dulce.)

Fenouil de Florence. Fenchel. Finnochio di Napoli. Hinojo.

A delicious Italian vegetable which tastes quite like celery, but sweeter and more delicate in flavor. Sow at intervals from March to July $1 / 2$ an inch deep, and 18 inches apart, and when the plants are large enough, thin to 8 inches in the row and cultivate frequently. The enlarged leaf-bases are usually boiled in preparation for the table, but the bottom and stalk are blanched by drawing the earth up to them like celery. This is usually done when the enlargement of leaf stalk at base is about the size of a hen's egg, and in about 10 days cutting may begin and continue as the plants increase in growth. Pkt. 5 and 10 cts., oz. 30 cts., $1 / 4$ lb. 90 cts., 1 lb. $\$ 3.00$. Postpaid.

\section{G H E R K I N \\ (See Cucumber.) \\ H O R S E R A D IS H}

(Cochlearia Armoracea.)

Rabano-Picante. Meerctig. Rafano.

It seems that there is always a good market for well-grown roots, and most persons would be astonished to know how many thousands of tons of horseradish are annually required to satisfy the demand. Soil for horseradish should by all means be deep, and the richer it is the larger and more salable will be the roots. The cuttings should be placed in rows not less than $2 \frac{1}{2}$ feet apart, 3 inches deep, allowing from 9 to 12 inches between the plants in the row. It will be noted that the cuttings have one end cut at an angle, and care must be taken to see that this slanting end is put down. When the ground is well warmed, the cuttings shoot up luxuriant leaves and the crop is then cultivated much as corn would be. 100 cuttings are enough for a row of 100 feet. 10,000 are required for an acre, and we advise planting in either March or April, although May is not too late. Nothing is more easily grown, and many gardeners will find it convenient to put the cuttings between cabbage or some other winter crop, the horseradish making little growth until spring is well advanced. The roots are plowed out like potatoes in the fall, trimmed neatly, and can usually be satisfactorily sold at once; if desired, they may be held through the winter, and it should be noted the root continues to grow in diameter long after the tops have died down.

Maliner Kren. The remarkable Bohemian horseradish which, in a few years, has revolutionized this crop in the United all rankness. Our cuttings are from the original stock imported by the Department of Agriculture and carefully free from Dozen 40 cts.; 100, $\$ 2.00$. Postpaid.

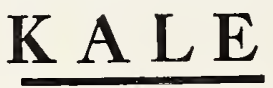

(Brassica Rapa Acephala.)

Chou Frise. Blatterkohl. Cavolo Verde. Breton Col.

CULTURE.-1 ounce of either Green Curled or Plain Kale or 2 ounces of Scotch are sufficient for 100 feet of drill. For an acre, $1 \frac{1 / 2}{2}$ pounds of either Green Curled or Plain, and from 3 to 7 pounds of the Scotch. Scoteh Kale being particularly

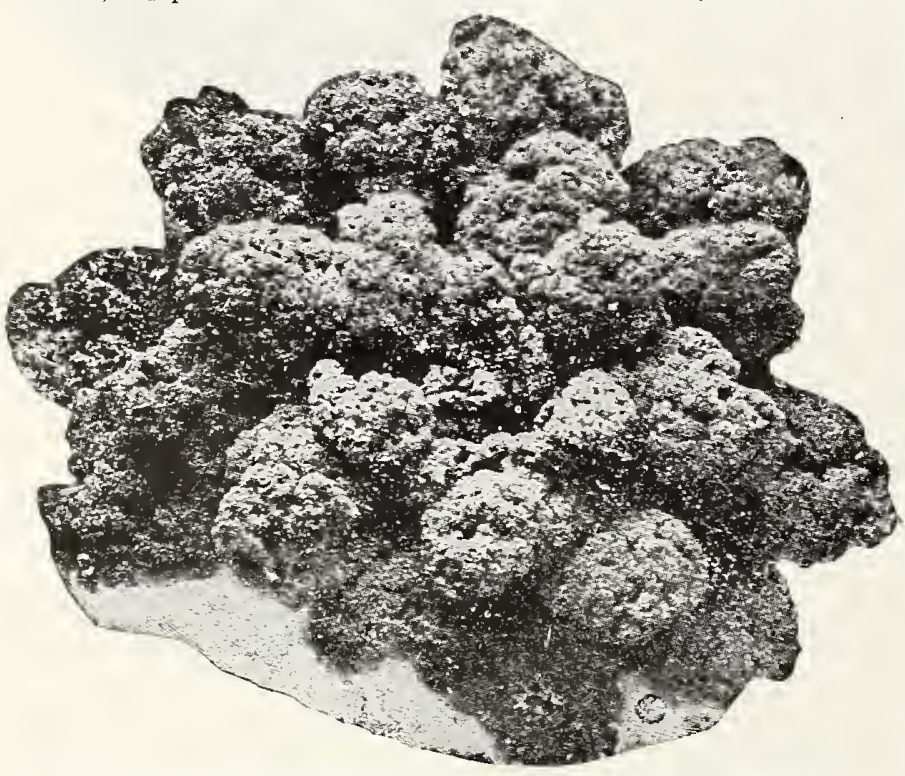
subject to the attacks of insects, both before and after coming up, it is necessary to sow it very thickly. Scotch Kale should be sown from the first to the last of August, and the Green Curled from the middle of August until the first of October. Plain Kale is sown nearly all the year round, either in drills or broadeast, and should be sown at intervals of 10 days in order to always have it tender. Sow $1 / 2$ inch deep in rows $2 \frac{1}{2}$ feet apart, allowing from 6 to 10 inches between the plants, and cultivate as cabbage. Kale, being a very strong feeder, heavy manuring is necessary to make a good crop, and when. ever the leaves show a tendency to turn yellow a topdressing of guano should be given at once.

\section{Tait's Thoroughbred Dwarf Green} Curīed Scotch. A bright green kale, which is Curled Scotch. grown extensively in the South for shipping during the winter, and of which we have the finest strain in existence. As it is never very tender, it is less desirable for family use than Tait's Favorite, but is much prettier, and, as a rule, more profitable for market. It is exceedingly dwarf, averaging little more than a foot in height and spreading widely, this habit of growth giving such protection to the stalk that cold weather rarely affects the plant. The leaves are intricately and most beautifully curled, and being hard and stiff, carry perfectly when packed. Pkt. 5 cts., oz. 10 cts., 1/4 lb. 25 cts., 1 lb. 90 cts. Postpaid.

Tait's Thoroughbred Dwarf Green Curled Scotch Kale.

Remember we deliver free at catalogue prices-except where noted. Write for special prices in large quantities. 


\section{KALE---Continued}

\section{Tait's Thoroughbred Dwarf Blue Curled}

Scotch. The leaves of this Kale, as may be implied from Dcotch. the name, are of a dark, bluish-green, which, to some, is more attractive than the bright green of our Dwarf Green variety. The leaves will also stand for a longer time in the spring before turning yellow. It will not yield so much per acre as the green variety, but will usually command a higher price. Those who sow Scotch Kale largely should have a portion of their acreage in this sort. Pkt. 10 ets., oz. 15 cts., 1/4 lb. 40 cts., 1 lb. \$1.50. Postpaid.

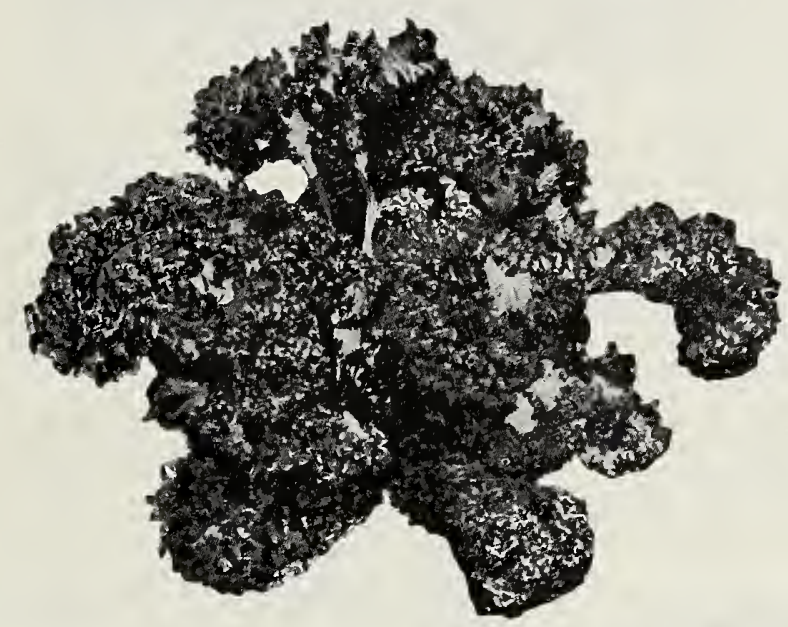

Tait's Thoroughbred Favorite Curled Siberian Kale.

\section{Tait's Thoroughbred Favorite Curled}

Siberian. When we introduced this now celebrated Green Surled Kale it at once demonstrated its superiority to all strains then in cultivation, and was promptly adopted by all the best growers. It is hardy, very productive, grows rapidly and is very slow running to seed in the spring. The shape and curling of the leaf give it the appearance of an immense feather, and like the Scotch, it retains its stiffness a long time after being cut. Pkt. 5 cts., oz. 10 cts., 1/4 lb. 25 cts., 1 lb. 90 cts. Postpaid.

Tait's Thoroughbred Plain. Gardeners who are this most useful of salads, sometimes called Norfolk Kale, Spring Sprouts and Hanover, have a pleasant surprise in store, for it is rapidly coming into universal cultivation in the South. While young it is very sweet and far more tender than any kind of kale, and the growth is so rapid that leaves may be cut in three weeks from seeding. Although usually sown in the spring, it may be sown in the fall as it endures cold perfectly, and can be cut at any time during the winter. It has no value for shipping, but it is very desirable for local markets. Oz. 5 cts., $1 / 4$ lb. 15 cts., 1 lb. 40 cts. Postpaid.

\section{KOHL-RABI}

(or Turnip-Rooted Cabbage)

(Brassica Caula Rapa.)

Chou-Rave. Kohlrabi. Cavola Rapa. Colinabo.

CULTURE.- 1 ounce is sufficient for 100 feet of drill. For an acre $1 \frac{1}{2}$ pounds. Sow $1 / 2$ an inch deep from April to July, at intervals of 4 weeks, as the bulbs are best when gathered young and tender, which is usually when they are 2 or 3 inches in diameter. The rows are usually made 18 inches apart, and the plants are thinned from 6 to 10 inches, the thinnings being transplanted if wanted. Work well to keep down weeds, but avoid throwing any earth in the crown.

Early White Vienna. The variety of this useful vegetable the

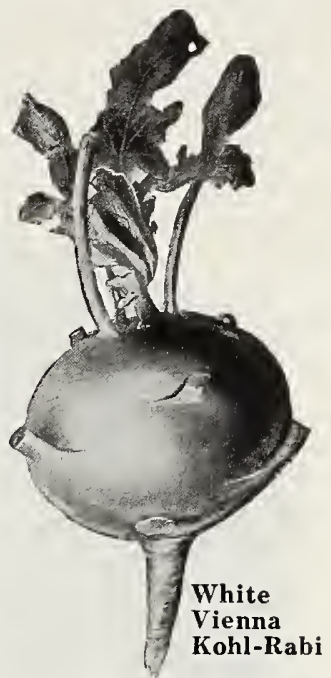
edible part of which is the enlarged globe-shaped stem. Pkt. 10 cts., oz. 25 cts., $1 / 4$ lb. 75 cts., 1 lb. $\$ 2.50$. Postpaid.

\section{LE E K \\ (Allium Porrum.) \\ Poireau. Porree, Lauch. Perro. Puerro.}

CULTURE.-1 ounce is sufficient for 100 feet of drill, 4 to 6 pounds for an acre. Sow in February and March in drills $1 / 2$ an inch deep and 9 inches apart, selecting light but rich soil. Thin to 1 inch and cultivate until the piants

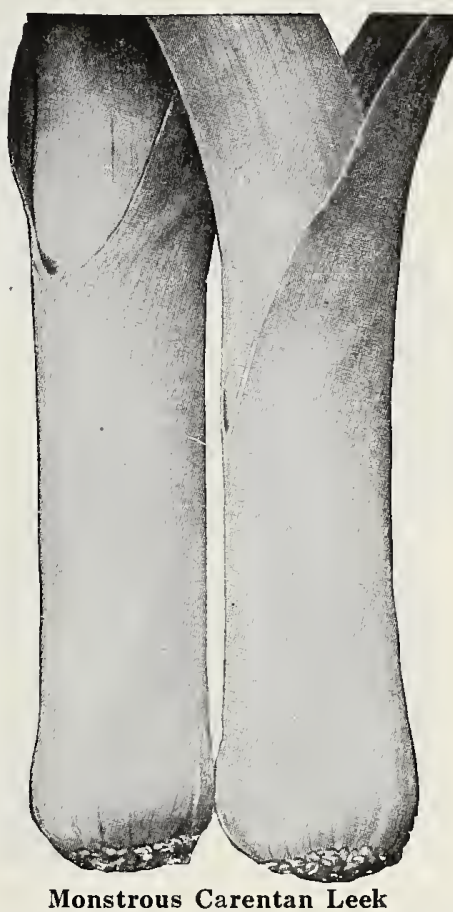
are 6 inches high. They are then ready for transplanting, and should be removed from the seed bed carefully, the leaves being trimmed to half their length. Have the rows 18 inches apart, and set the plants with a dibble from 4 to 6 inches, allowing the earth to come almost to the leaves. Keep the soil well loosened, earthing up gradually as the leeks increase in size, so as to secure thorough blanching of the bottoms.

Monstrous Carentan. This will be entar. found a very for market gardening as the broad, thick stems are extra large. Good for either home or market. Pkt. 10 cts., oz. 20 cts., 1/4 lb. 60 cts., 1 lb. $\$ 2.25$. Postpaid.

American Flag. An excellent, hardy leek, with long stems that are of good quality. Pkt. 10 cts., oz. 20 cts., $1 / 4$ lb. 60 cts., 1 lb. \$2.25. Postpaid. 


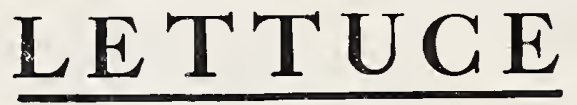

(Lactuca Sativa.)

Laitue. Lattich-Kopfsalat. Lattuga. Lechuga.

CULTURE.-1 ounce is sufficient for 100 feet of drill; 8 ounces will produce enough plants to set out an acre. To raise the best of lettuce, rich soil with plenty of humus is needed, and we particularly recommend that it be planted after

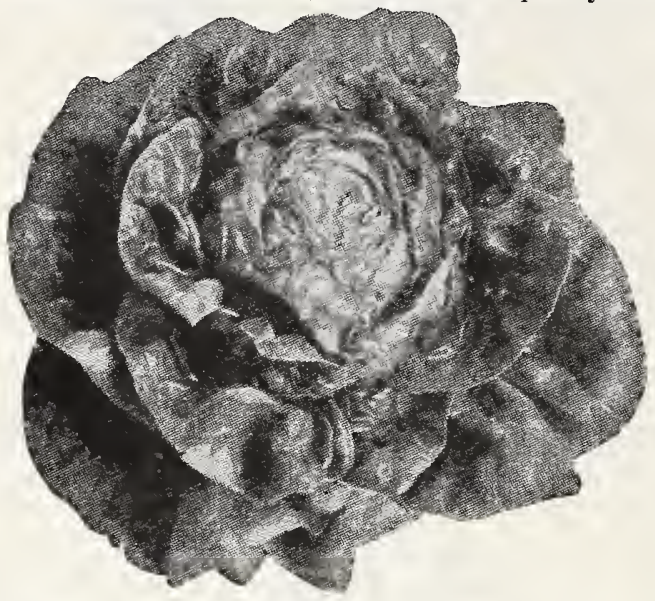

Tait's Thoroughbred Earliest of All Lettuce. clover, whenever possible. Norfolk truckers treat the head varieties in the same way as cabbage, sowing the seed the last week of September in beds $1 / 8$ of an inch deep, and setting the plants in the open field during November. While lettuce may be set in rows 18 inches apart, it is generally set in beds 4 feet wide with 4 rows to the beds, leaving 9 inches between the plants. Shelter from the wind is of such immense advantage that if no natural wind breaks are available it pays handsomely to provide artificial ones made from cornstalks or cheap lumber. For the family garden, seed may be sown as late as October in a warm sheltered bed protecting it during severe weather with a covering of straw, or it may be transplanted into cold frames to head during the winter. For a succession, sow in bed from the last of March to the middle of May, covering the seed thinly as directed, but taking care to firm the surface. For several years lettuce has been in great demand during November and December, and large quantities are now grown for that market, the seed being drilled from the middle of July to the middle of August in 10 -inch rows on beds 4 feet wide at the rate of 5 pounds to the acre, and thinned to 9 inches when large enough.

Our THOROUGHBRED strain of BIG BOSTON LETTUCE is unsurpassed. The superior quality is recognized wherever it goes and each year we sell thousands of pounds to the largest lettuce growers from Norfolk to Florida. If you grow BIG BOSTON LETTUCE you should use our THOROUGHBRED strain.

Tait's Thoroughbred Earliest of All. Growlettuce, either for pleasure or profit, will find it to their advantage to have a portion of their crop in this variety. As the name implies, it is the earliest heading lettuce in cultivation, and does equally as well under glass or in the open ground. The heads are of medium size, fold tightly, and are a rich creamy tint, the outside leaves being similar in color to those of the Big Boston. Few lettuce are handsomer in appearance or of better quality. Pkt. 10 cts., oz. 25 cts., $1 / 4$ lb. 75 cts., $1 \mathrm{lb}$. $\$ 2.50$. Postpaid.

Wayahead. A va a much like the May King, but a little earlier and larger. The tightly folded heads have a rich yellowish tint, and are tender and of good flavor. Pkt. 10 cts., oz. 25 cts. 1/1 lb, 60 cts., 1 lb. \$2.00. Postpaid.

May King. F or ing or field culture, this early lettuce will be found most satisfactory. The round head is a rich yellow, very solid, tender and of delicious flavor. making a most attractive appearance in its setting of light green leaves that have just a faint tint of brown. A splendid kind for the home garden. Pkt. 10 cts., 0z. 25 cts., $1 / 4$ lb. 60 cts., 1 lb. $\$ 2.00$. Postpaid.

Big Boston. A grand variety, and more universally by Market than any other lettuce. It is grown ners everywhere in the open ground for fall, in frames for early spring, and forced under glass for winter. Big Boston has broad, comparatively smooth but very stiff leaves surrounding a solid head of perfect form. The head is beautifully blanched and in crisp tenderness is all that could be desired. After maturing the leaves often take on touches of brown. It keeps its fine quality longer after being cut than most other sorts. thus giving it an added value for shipping. O ur Thoroughbred strain is praised by Market Gardeners alolıg the entire southern seacoast, and is as near perfection as a vegetable can be bred. Pkt. 10 cts., oz. 15 cts., $1 / 4$ lb. 40 cts., 1 lb. $\$ 1.50$. Postpaid.

New York T h is ometimes soid variety the names of Wonderful and Los Angeles Market is becoming very popular in the South and East. It is a curled and crisp heading variety, medium large, dark green and slightly curled on the edges, while the head is well blanched and firm. Good for either spring, summer or fall sowing. Slow in running to seed. Pkt. 10 cts., oz. 30 cts., $1 / 1$ Ib. 90 cts., 1 lb. $\$ 3.00$. Postpaid.

Remember we deliver free at catalogue prices-except where noted. Write for special prices in large quantities. 


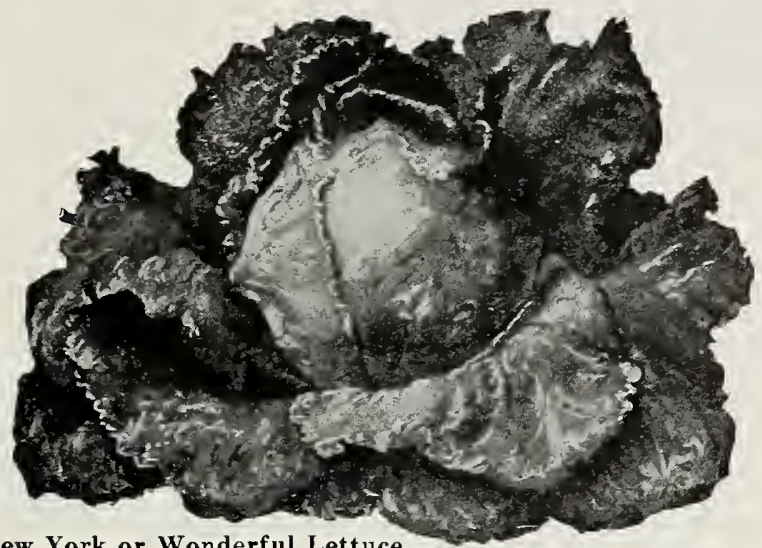

New York or Wonderful Lettuce.

Iceberg. A beautiful curled or crisp heading sort that is very similar to good for either forcing or outdoor culture. cts., 1 lb. \$2.50. Postpaid.

Tait's Thoroughbred Midsummer. Few crops profitable than summer lettuce, but the heat makes success extremely difficult in the South. In this strain we offer a lettuce which has given splendid results wherever grown in the South. It is unusually handsome, of the largest size, and more solid than most cabbage lettuce, while in quality it is all that could be desired. The outer leaves are a dull dark green splashed with brown, the heart being creamy yellow. Pkt. 10 cts., oz. 25 cts., 1/4 lb. 70 cts., 1 lb. $\$ 2.25$. Postpaid.

Hanson. One of the best known of the old varieties, head is white and the leaves light green, the inside blanching to a pure white, somewhat fringed on the edges. Pht. 10 cts., oz. 25 cts., $1 / 4$ lb. 60 cts., 1 lb. $\$ 2.00$. Postpaid.

\section{California Cream Butter. One of the sorts} running to seed, and, therefore, adapted to summer use. The head is of medium size, compact, and almost perfectly round; the outer leaves are a rich glossy green, splashed with brown markings. Pkt. 10 cts., oz. 25 cts., $1 / 4$ lb. 60 cts., 1 lb. $\$ 2.00$. Postpaid.

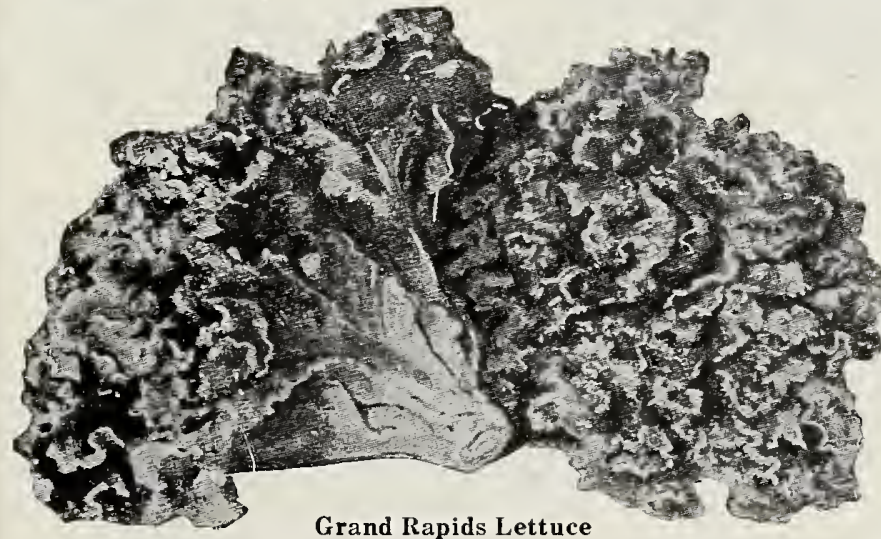

Grand Rapids Lettuce
Unrivaled A large, light, bright green heading lettuce a trifie earlier maturing and having no red or bronze shadings on the leaves. Heads are large, firm and of excellent quality. Sometimes called Improved Big Boston, Champion of All, and Simon's Cabbage Head. Pkt. 10 cts., oz. 25 cts., 1/4 lb. 75 ets., 1 lb. \$2.50. Postpaid.

Tennis Ball. (Black Seed.) One of the best heading Iennis Ball. lettuces, suitable for early planting outdoors and also for forcing. The plants are large, with thick, bright green leaves. They form very solid heads, the inner leaves blanching to a rich creamy white, and are crisp, tender and buttery. Pkt. 10 cts., oz. 25 cts., $1 / 4$ lb. 60 cts., 1 lb. $\$ 2.00$. Postpaid.

Grand Rapids. This loose leaved variety has become rapdis. a favorite everywhere, especially in the West, but must not be used where a head lettuce is wanted. Of not the best quality when grown out of doors, but under glass it becoines tender and sweet. The leaves are light green, free from any brownish markings and are merely bunched together. The edges being daintily fringed, it is very decorative for garnishing, and is largely used for that purpose. Pkt. 10 cts., oz. 25 cts., $1 / 4$ lb. 60 cts., 1 lb. $\$ 2.00$. Postpaid.

\section{ROMAINE or COS LETTUCE}

White Paris. In the South too little attention has been given to Cos lettuce, but we find that gardeners are learning to appreciate their tenderness and delicious flavor. The Trianon is one of the earliest sorts and makes an excellent well blanched head if the leaves are tied together. Pkt. 10 cts., oz.. 25 cts., 1/4 lb. 70 cts.; 1 lb. $\$ 2.25$. Postpaid.

\section{Giant White.}

This variety for $\mathrm{m} \mathrm{s}$ a large light green plant with the head well folded and nearly white, quite firm, but not so early as the Wh it e Paris. Pkt. 10 cts., oz. 25c., $1 / 4$ lb. 70 cts., 1 lb. \$2.25. Postpaid.

\section{MANGELS}

\section{(See Beet.)}

\section{MARTYNIA}

CULTURE.-1 ounce is sufficient for a row of 100 feet in hills. 1 to 3 pounds for an acre. If wanted early, the seed should be sown in a hot-bed and the seedlings transplanted into the open ground as soon as the weather becomes warm.

The least troublesome culture, however, is to sow in April or May $1 / 2$ an inch deep in hills 3 feet apart, thinning to a single plant in each hill.

Proboscidea. The pods of Martynia are universally ca. liked for pickles, having a very agreeable piquancy. They should be gathered while small and tender, and pickled as soon as possible after being picked. Pkt. 10 cts., oz. 25 cts., $1 / 1$ lb. 65 cts., 1 lb. $\$ 2.50$. Postpaid. 


\section{MUSK M E LON}

(Cucumis Melo.)

Melon-Muscade. Meione. Popone. Muscate.

CULTURE.-1 ounce is sufficient for a row of a 100 feet planted in hills; 3 pounds will plant an acre twice, more or less replanting being usually necessary. The melon delights in warm, rich soil with perfect drainage, and they can never be grown to perfection under unfavorable conditions. Very good melons, however, can be grown on almost any land if the trouble is taken to dig holes 2 feet square, filling them with a rich compost of wood-mould and cow-pen manure. Plant $3 / 4$ of an inch deep from April to June in rows 6 feet apart, leaving not less than 4 feet between the hills, putting about 10 seed to the hill. As insects are often very destructive, it is best not to thin at all until the plants are well started. When they are large enough to be safe, thin to 2 in a hill, and keep the ground mellow and free from weeds. Those who make a specialty of muskmelons will find it advantageous to start the seed under protection of glass, so as to have the plants ready by the time seeds could be usually planted in the open ground. For this purpose our Norfolk growers use baskets made after the fashion of a strawberry quart, without a bottom from a strip that is manuiactured for that purpose. Transplanting from these boxes never checks plants in the least, as none of the roots are disturbed. Spraying is absolutely necessary for best results, and neglect of this means either total loss of the crop or inferior quality in what fruit is made.

\section{PINK FLESHED VARIETIES}

\section{Tait's Thoroughbred} I d e a 1. Introus more than twenty years ago, the melon is still very popular, and for the past four years has taken the prize over all otiner sorts at the Arkansas Valley Fair at Rocky Ford, Colorado. The Ideal is very early, of the medium size, attractive as to the exterior, deep-fleshed, richly c ol o red, crystalline in grain, mor e exquisitely aromatic than any other sort, and absolutely unique in flavor. In productiveness it is probably unequalled, for we have actually cut from one vine twenty-four well -formed melons, nearly all of firstclass quality, and groups of three or four perfect specimens lying so closely around the $h$ ill as to touch each other may be frequently seen in any well-cultivated field of Ideals. The color of the skin is nearly that of the

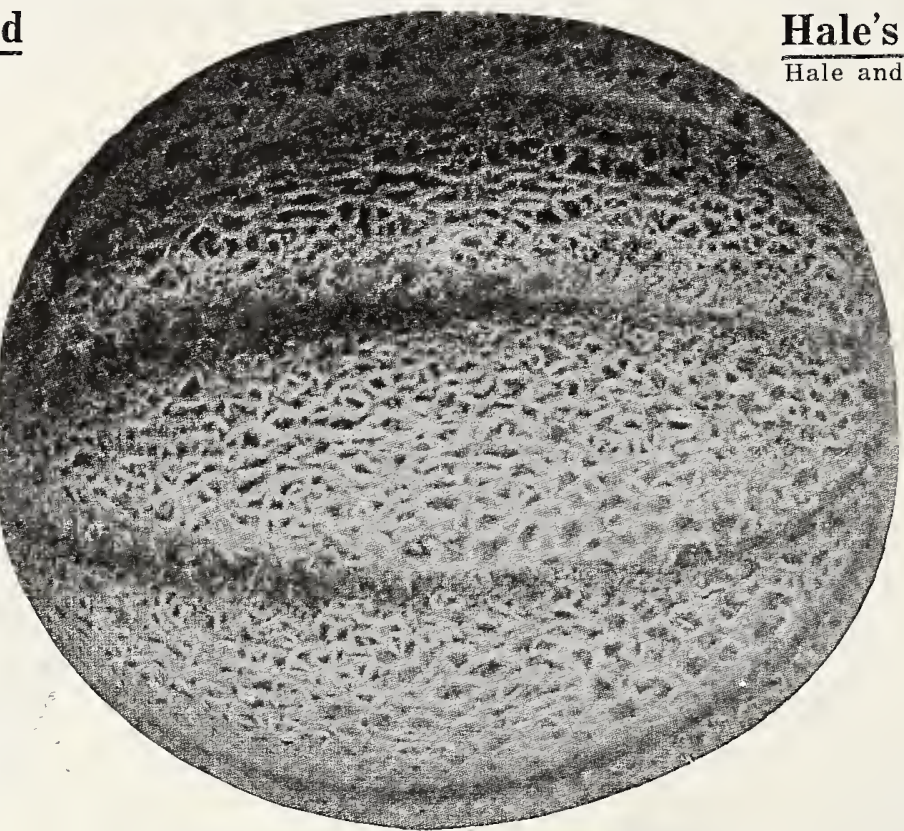

Tait's Thoroughbred Ideal Muskmelon.

The Finest Pink Fleshed Muskmelon in the World.
Osage, but the resemblance goes no further, as the Ideal is of altogether different shape and size, and is covered with an elaborate, well-defined mass of network. The flesh is so deeply colored as to look quite red, and the taste of a representative specimen is simply incomparable. In proportion to its size, it is easily the heaviest of all muskmelons, owing to the thickness and firmness of the flesh, qualities which enable it to endure much handling and long shipment. An irregular percentage of the melons show green flesh, the quality of which is identical with the salmon-fleshed fruit, but we have been unable to absolutely fix the type. What the Knight is to green-fleshed muskmelons, the Ideal is to the salmon-colored type. Pkt. 10 cts., oz. 15 cts., 1/4 lb. 50 cts., 1 lb. \$1.75. Postpaid.
Osage. This is a large-fruited, dark-skinned Melon, the - appearance of which is much enhanced by the shallow grey netting which covers it so evenly. The very thick red flesh is of pleasing flavor. Pkt. 10 cts., oz. 15 cts., 1/4 lb. 35 cts., 1 lb. $\$ 1.35$. Postpaid.

Banana. Fruit of this variety is nearly two feet long Banana. when well grown, and the light yellow skin is entirely without netting or ribs. The orange flesh, while sometimes finely flavored, is generally of indifferent quality. Pkt. 10 cts., oz. 15 cts., $1 / 4$ lb. 50 cts., 1 lb. $\$ 1.75$. Postpaid. 
Tait's 'Thoroughbred Bottomly. The most popular cantaloupe grown by the market gardeners around Norform in shape but it possesses ali the hitherto unequal qualities of that melon, and is less liable to blight. However, it is about ten days later. The fiesh is of delicious quality, and when grown under ideal conditions, is always sweet. It commands the highest market price, and those who have grown it unite in declaring it to be the best second early sort. We consider this and oux "Knight" the most profitable kinds for market gardeners to grow. Pkt. 10 cts., oz. 25 cts., 1/4 lb. 75 cts., 1 lb. $\$ 2.50$. Postpaid.

Tait's Thoroughbred Knight. Introduced by us fifteen years ago, this splendid melon still holds first place as Iaits Ahoroughbred Knight. the earliest green-fieshed variety of desirable shape and size. In shape it somewhat resembies Rocky Ford, but is ten days earier, larger and often shows a trifle more pointed at the stem end, the outside being handsomely netted. The fiesh is very thick, edged with golden yellow, of splendid quality and having a sweetness indescribably delicious, with a remarkable aroma. Every grower of melons for either home or market should have a portion of their crop in this remarkable melon. Our Thoroughbred Strain of this melon outclasses all the strains commonly sold. Pkt. 10 cts., oz. 20 cts., $1 / 1$ lb. 60 cts., $1 \mathrm{lb}$. $\$ 2.00$. Postpaid.

Tait's Thoroughbred Jenny Lind. The Jenny Lind's "fineness" of flavor-quite distinct from the agreeable sweet of the average good melon-its convenient size, earliness, and the fact that a hundred may usually be long time against the newer and larger muskmelons. This small, flattened, green-fieshed sort needs no detailed description, and there are few people unfamiliar with it. Pkt. 5 cts., oz. $10 \mathrm{cts.g} 1 / 4 \mathbf{l b} .30 \mathrm{cts.}, 1 \mathrm{lb}$. $\$ 1.00$. Postpaid.

Hanover. An extra eariy green fleshed variety that market gardeners find to come in ahead of nearly every other

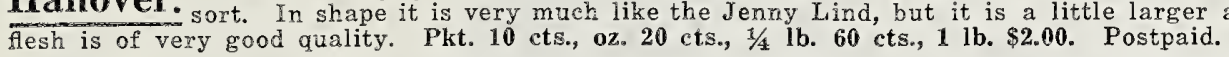

Rocky Ford, or Netted Gem. A popular shipping melon that is grown in large quantities in Colorado and AriFord, or Netted is early, prolifie, and a good sort for either home or market. The fruit is rather small, almost round, and the thick flesh is of fine grain and delicious fiavor. In our judgment, however, it is not as good as the Knight, Bottomly, or Delicious Gold Lined Rocky Ford. As is often the case with vegetables, the name means very little, and "Netted Gems" are to be had, which have little in common with our Thoroughbred strain. Pkt. 5 cts.s, oz. $10 \mathrm{cts}$., $1 / 4 \mathrm{lb}$. $30 \mathrm{cts}$., $1 \mathrm{lb}$. $\$ 1.00$. Postpaid.

Gold Lined Rocky Ford. Listed under numerous names, this gold-lined oval-shaped melon has undoubtedly the are shown. It is about the same earliness as the Bottomly, of delicious flavor, and the gold lining next to the seed cavity -which is extremely smail-adds greatly to its attractiveness. Pkt. $10 \mathrm{cts}$., oz. $15 \mathrm{cts.}, 1 / 4 \mathrm{lb} .40 \mathrm{cts} ., 1 \mathrm{lb}$. \$1.50. Postpaid.

Green Montreal. A Canadian introduction which Green Montreal. is apparently best suited to that climate, although used in many other sections. The fruit grows large, round, somewhat flattened at the ends and covered with a dense netting, the quality of the flesh being first class. Pkt. 10 cts., oz. $15 \mathrm{cts}$., $1 / 4 \mathrm{lb} .40 \mathrm{cts}$. $1 \mathrm{lb}$. $\$ 1.50$. Postpaid.

New Honey Ball This meion has attracted conNew Honey Ball. siderable attention the past year, and we suggest that all growers of muskmelon give it a trial. The melons mature early, are of medium size, and very prolific; as many as a dozen melons can often be found on a single vine. The rind is quite hard and tough, which insures excellent protection for shipping. Pkt. 10 cts., oz. 30 cts., $1 / 4$ lb. 90 ets.,

1 lb. $\$ 3.00$. Postpaid.

Honey Dew. As its plies, this melon is as sweet as honey, with a fiavor distinctly its own. The rind is smooth, light greea, changing to a creamy yellow when ripe, and the fiesh green, very, thick, fine grained, and can be eaten to the very rind. It is a little later than the Rocky Ford, and nearly double the size. Pkt. 10 cts., oz. 15 cts., $1 / 4$ lb. 40 ets., 1 lb. $\$ 1.50$. Postpaid.

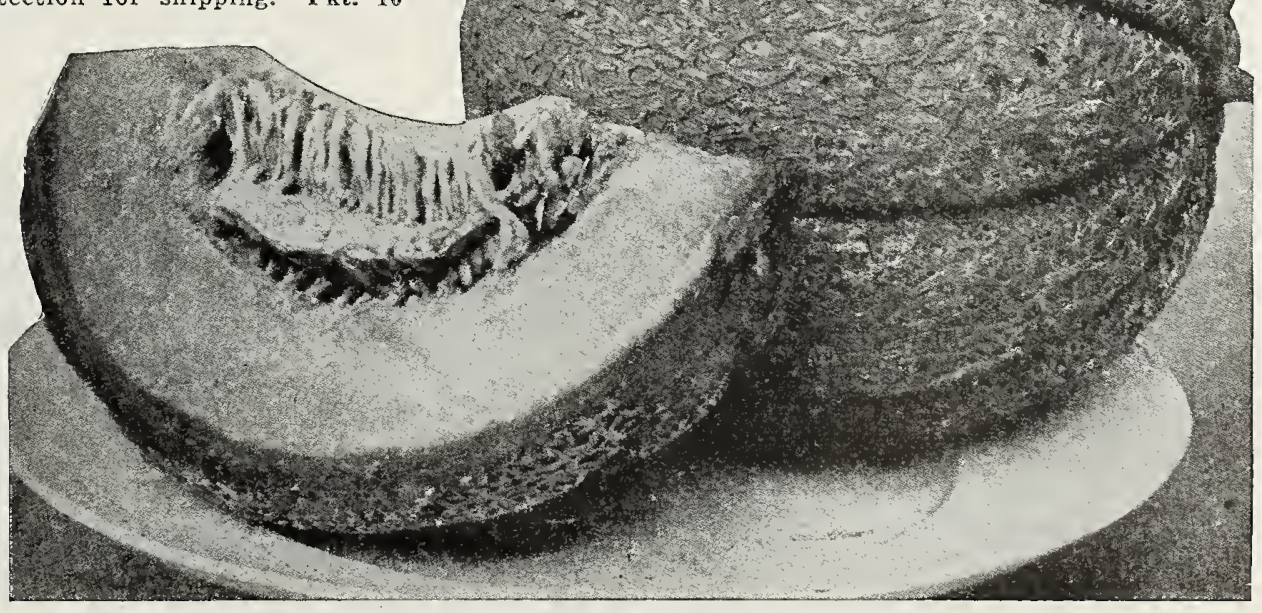

Tait's Thoroughbred Bottomly Muskmelon.

Remember we deliver free at catalogue prices-except where noted. Write for special prices in large quantities. 


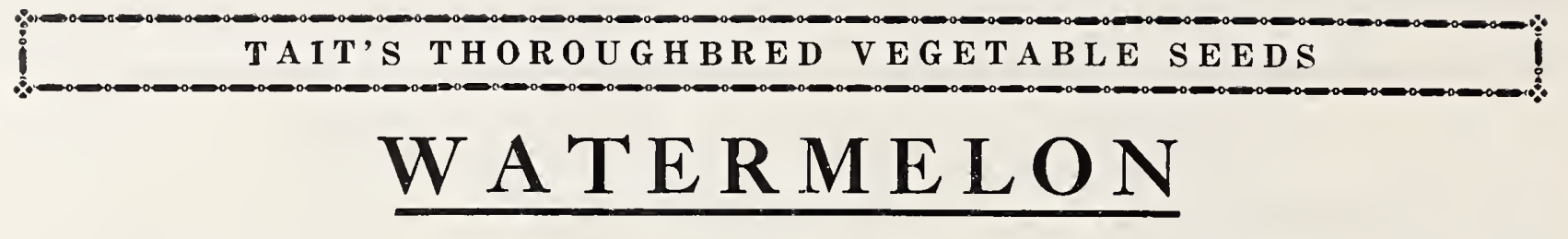

(Cucurbita Citrullus.)

Melon d'Eau. Wasser-Melone. Melone d'Aqua. Zandia.

CULTURE.-1 ounce is sufficient for a row of a 100 feet in hills; 2 or 3 pounds will plant an acre in hills. A rich but light and well-drained soil is needed to produce the best results. Plant the seeds 1 inch deep from April to June in hills not less than 8 feet apart each way. Avoid planting until the warm weather has become settled, as the vines will never thrive if checked by cold, and it really pays to use the seed more lavishly than indicated above. Watermelon seeds have so many enemies that defective stands are almost the rule rather than the exception, and sometimes the delay from replanting means failure of crop; no matter how many seeds are put in the hills, they should each be pushed in separately in order to guard against a bird or other destroyer making a clean sweep of the pocket. After the first plowing, cultivation must be shallow and the crop "laid by" as soon as the ground is well covered.

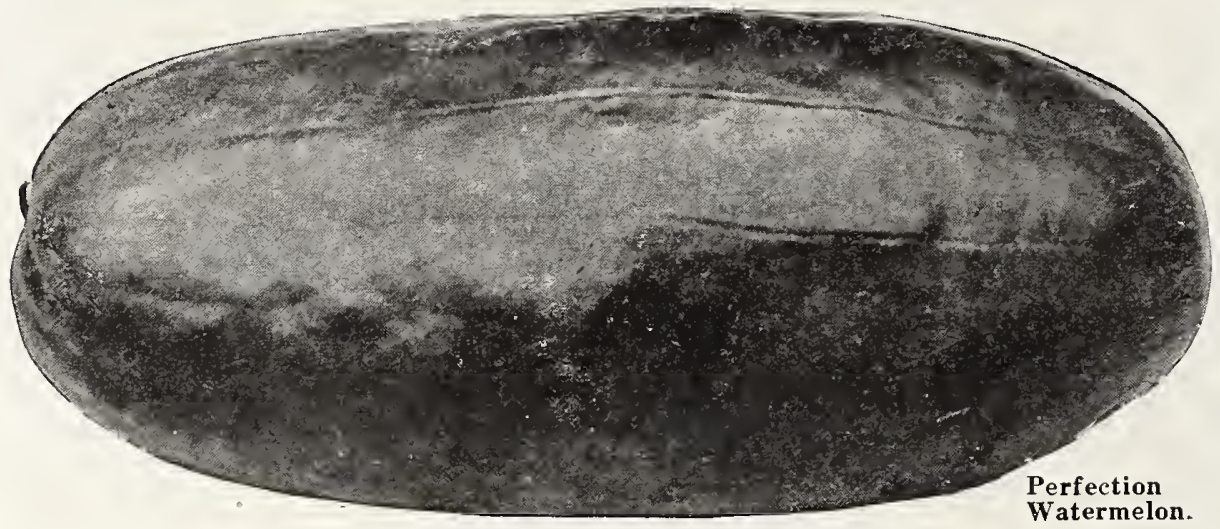

Perfection A new variety Perfection. that should be tried by all melon growers, as it promises to become of great importance. It is medium early, will average from forty to sixty pounds in weight, and is of the popular oval or oblong shape desired by most people. The flesh is bright red, very sweet and free from fibre. The rind is a dark glossy green, and although thin is extremely tough. It is an ideal melon for either home or market and its beautiful shape and color will attract such attention that it is destined to become very popular. Pkt. 5 cts., oz. 10 cts. $1 / 4$ lb. 35 cts., 1 lb. $\$ 1.25$. Postpaid.

Tom Watson. The most popular shipping melon to date, and a very good sort for the home garden. In shape it is long, dark green, showing very distinctly a fine veining under its general color. One of its specially attractive characteristies is the high permanent gloss, the fruit always looking as if it had just left the vine. No melon in cultivation is more uniform in size, shape and coloring, scarcely any being under desirable size. In quality it ranks with the best melons, the luscious crimson flesh is very sweet and of the best flavor. Pkt. 5 cts., oz. $10 \mathrm{cts}$., $1 / 1 \mathrm{lb} .25 \mathrm{cts}, 1 \mathrm{lb} .85$ ets. Postpaid. Indian Chief. Very similar to Tom Watson and a splendid shipping variety. Pkt. 5 cts., oz. 10 cts., $1 / 4$ lb. 25 cts., 1 lb.

Kleckley Sweet. Known also as Monte Cristo. This melon for local markets or the family garden will be found most Kleckley Sweet. desirable, as it is one of the sweetest varieties in cultivation. It is long, with a dark-green rind, and knife like thin glass-a sign which all who tenderness of the rediar with watermelons will recognize as the surest indication of delicate, crystalline flesh. This and Florida Favorite are the two best melons for the family garden, but with such a brittle rind should never be subjected to the jars and rough handling of railroads. Pkt. 5 cts., oz. 10 cts., 1/4 lb. 25 cts., 1 lb. 85 cts. Postpaid.

\section{Florida Favorite.}

There are few watermelons equal to this in sweetness and tenderness, but it is rather undersize. The shape is oblong and the color of the rind dark green with light green stripes. The flesh is really melting, having less fibre than any other except perhaps Kleckley Sweet. Notwithstanding the introduction of so many large, fine melons, we still have quite a demand for it for home garden, and it is still holding its own for all local markets, so great is its reputation for uniformly good quality. Pkt. 5 cts., oz. 10 cts., $1 / 4$ lb. 25 cts., 1 lb. 85 ets. Postpaid.

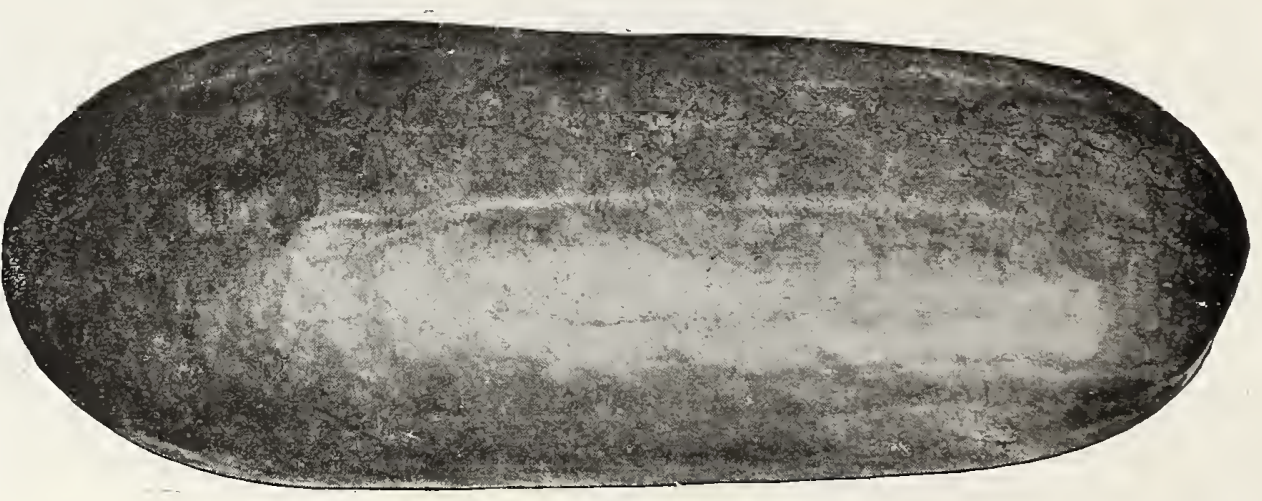

Tom Watson Watermelon.

Remember we deliver free at catalogue prices-except where noted. Write for special prices in large quantities. 


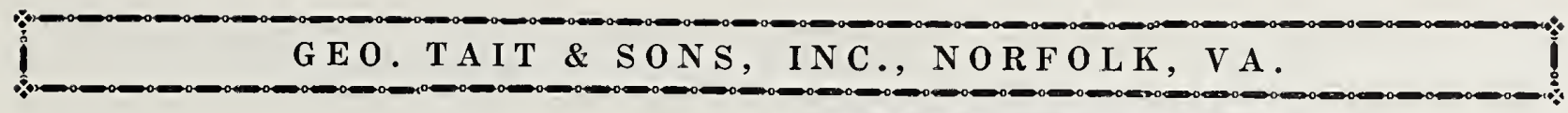

Owen's Gray. c o on ered by local growers an improvement on Irish Gray, and one of the surest melons to make a crop. The rind is a mottled light green, quite thin but exceedingly tough, and on account of its color, does not sunburn like the dark green varieties. The flesh is bright sparkling red, very sweet, irm, and of splendid flavor. It is a good shipping melon, remarkably productive, averaging in size nearly as large as Tom Watson, and produces $25 \%$ more salable melons than most sorts. Pkt. 5 cts., oz. 10 cts., $1 / 4$ lb. 30 cts., 1 lb. $\$ 1.00$. Postpaid.

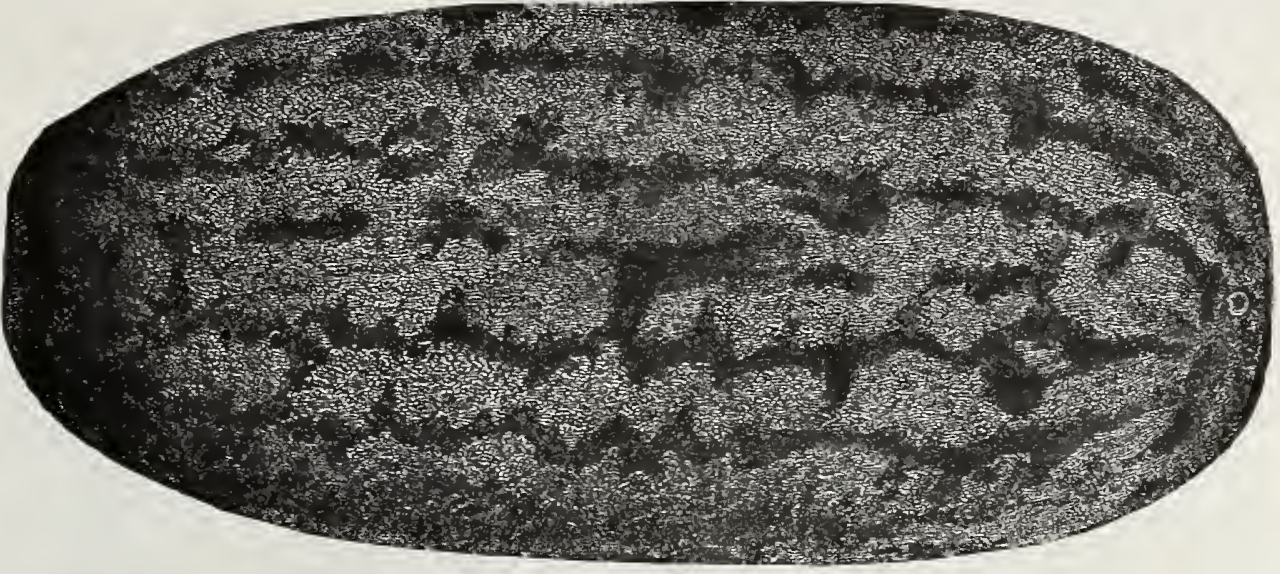

Halbert Honey. For sections where the summers are short, this fine melon appears to be ideal, as it is a remarkably - rapid grower. It is a little smaller than the Kleckley Sweet- to which it bears a close resemblance -and is almost of equal quality and attractiveness, having a smooth, dark green rind of extraordinary brittleness. It is, of course, best adapted to home use and local markets, and is recommended principally to those who find their seasons too short for the safe maturing of the later varieties. Pkt. 5 cts., $0 z .10 \mathrm{cts.}, 1 / 4 \mathrm{lb} .25 \mathrm{cts} ., 1 \mathrm{lb} .85 \mathrm{cts}$. Postpaid.

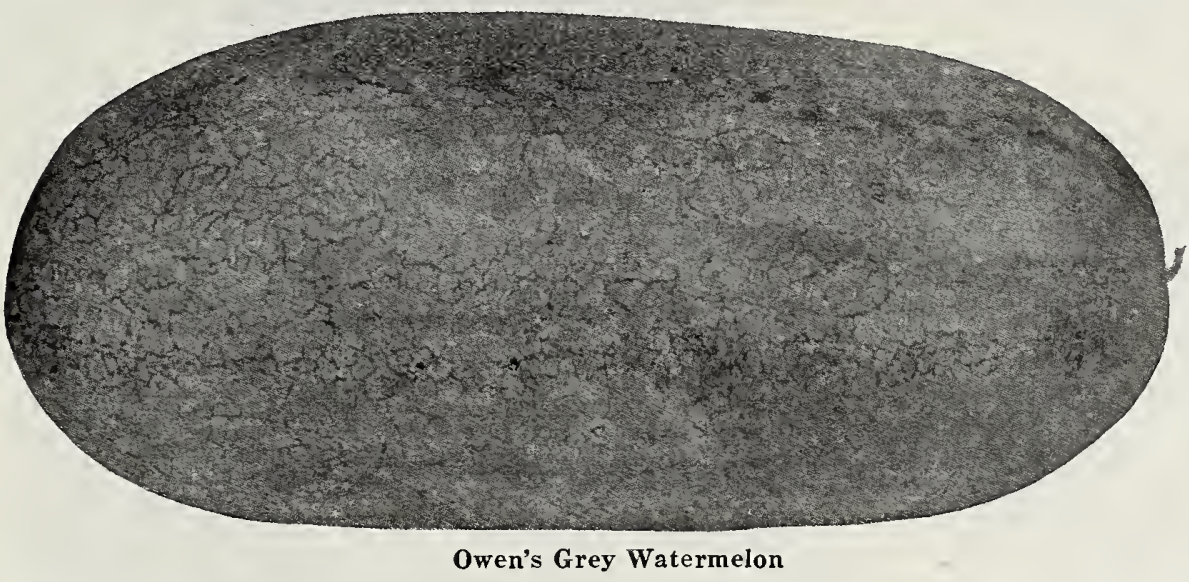

Wonderful Sug a r:

A handsome oblong melon and a good variety for home use or local markets. In shape and markings it is not unlike the Georgia Rattlesnake, though totally different in other respects. Remarkable for its sweetness. Pkt. 5 cts., oz. 10 cts., 1/4 lb. 25 cts., 1 lb. 85 cts. Postpaid.

\section{Georgia Rattlesnake.}

This melon, known also as the Striped Gypsy, is an oblong variety "with decided stripes of light and dark green. The rind is tough and rather thick, while the flesh is bright red and of splendid quality. It attains a large size, is particularly handsome and can be shipped perhaps as far as any other kind. A splendid variety for late use. Plt. 5 ets., oz. 10 cts., $1 / 4$ lb. 25 cts., 1 lb. 85 cts. Postpaid.

Shaker Blue. The rind of this melon is dark green, striped with bands of lighter green, but when ready for market She the appearance of being a solid bluish green color. The flesh is bright red, crisp and well flavored. In quality it is the best of the large round watermelons. Pkt. 5 cts., oz. 10 cts., $1 / 4$ lb. 30 cts., 1 lb. $\$ 1.00$. Postpaid.

Nigger Head. A name a round melon of medium size that has become popular on our local markets in the past two or three years. The skin is very dark green with very faint stripes, the flesh is deep red and ripens down to the rind and is of good quality. Pkt. 5 cts., oz. 10 cts., $1 / 4$ lb. 30 cts., 1 lb. $\$ 1.00$. Postpaid.

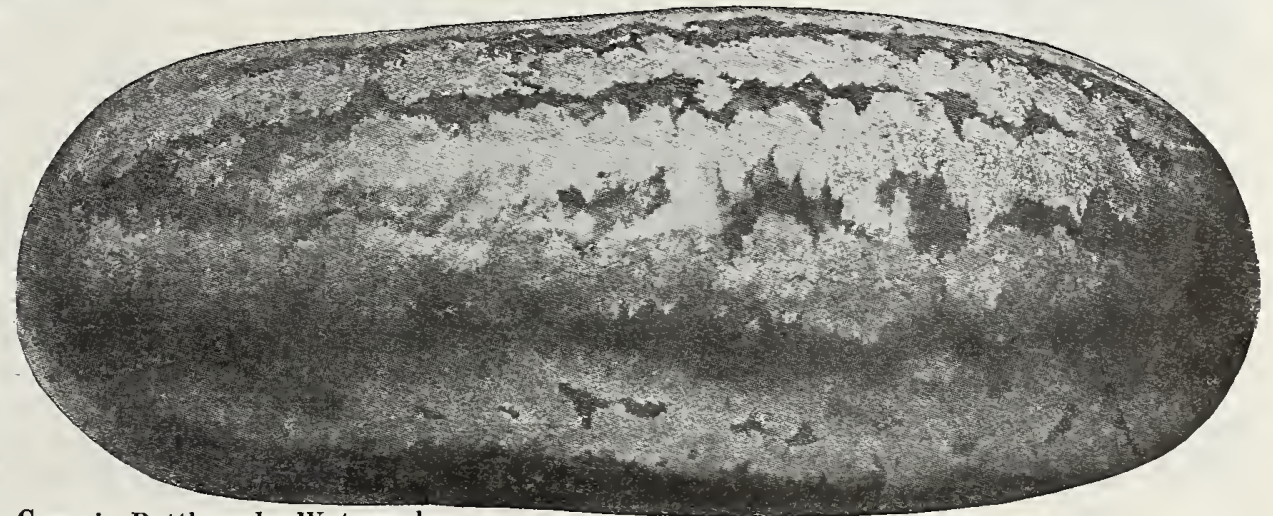

Georgia Rattlesnake Watermelon

Remember we deliver free at catalogue prices-except where noted. Write for special prices in large quantities. 


\section{MUSHROOM SPAWN}

(Agaricus Campestris.)

Champignon. Champignonbrut. Fungo-Pratajolo. Seta.

CULTURE.-10 bricks will cover 100 square feet. The "culture" should be planted in beds, which nay be of any size desired, but are usually made 4 feet wide, 10 inches deep, and any length. Full cultural directions will be sent free with each order for Mushroom Spawn.

American Pure Culture Spawn. This spawn is produced by selecting spores from individual specimens and is the brick of manure, which, when planted, considered the best sort of Mushrooms, and is propagated and transferred to

\section{MUST A R D (Sinapis.) \\ Moutarde. Senf. Mostaza.}

CULTURE. -1 ounce is sufficient for 100 feet of drill; $1 \frac{1}{2}$ pounds will sow an acre. Sow February to October $1 / 4$ of an inch deep, broadcast, or in drills 18 inches apart, thinning to from 6 to 8 inches. By successive sowings every fortnight, beginning early in March, the salad may be had at its best until summer.

Fordhook Fancy. No other kind is nearis also the most productive, making an extraordinary amount of foliage. Pkt. 5 cts., oz. 10 cts. 1/4 lb. 20 ets., 1 lb. 75 cts. Postpaid.

Giant Southern Curled. A favorite in the South, growing Giant Southern Curled. very large, with a beautiful curled leaf. Tender and of especially good flavor. Pkt. 5 cts., oz. 10 cts., $1 / 4$ lb. 20 cts., 1 lb. 75 cts. Postpaid.

Chinese Broad-Leaved. When cooked like spinach the an agreeable flavor, and are much liked by all who care for this kind of "greens." They are often a foot or more in length, and have crimping much like that of a Savoy cabbage. Plit. 5 cts., oz. 10 cts., $1 / 4$ lb. 20 cts., 1 lb. 75 cts. Postpaid.

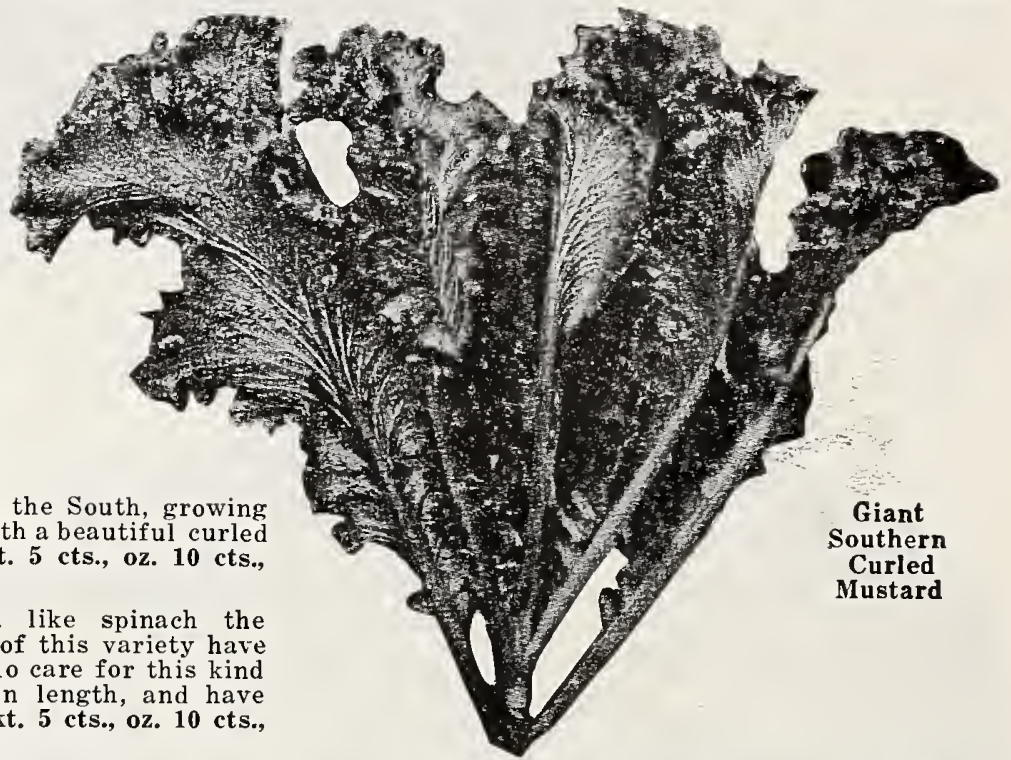

White London. The seeds of the white mustard are used principally for pickling and other domestic purposes, although the plant itself makes early greens, but only of fair quality. Oz. 5 cts., 1/4 lb. 15 cts. 1 lb. 50 cts. Postpaid.
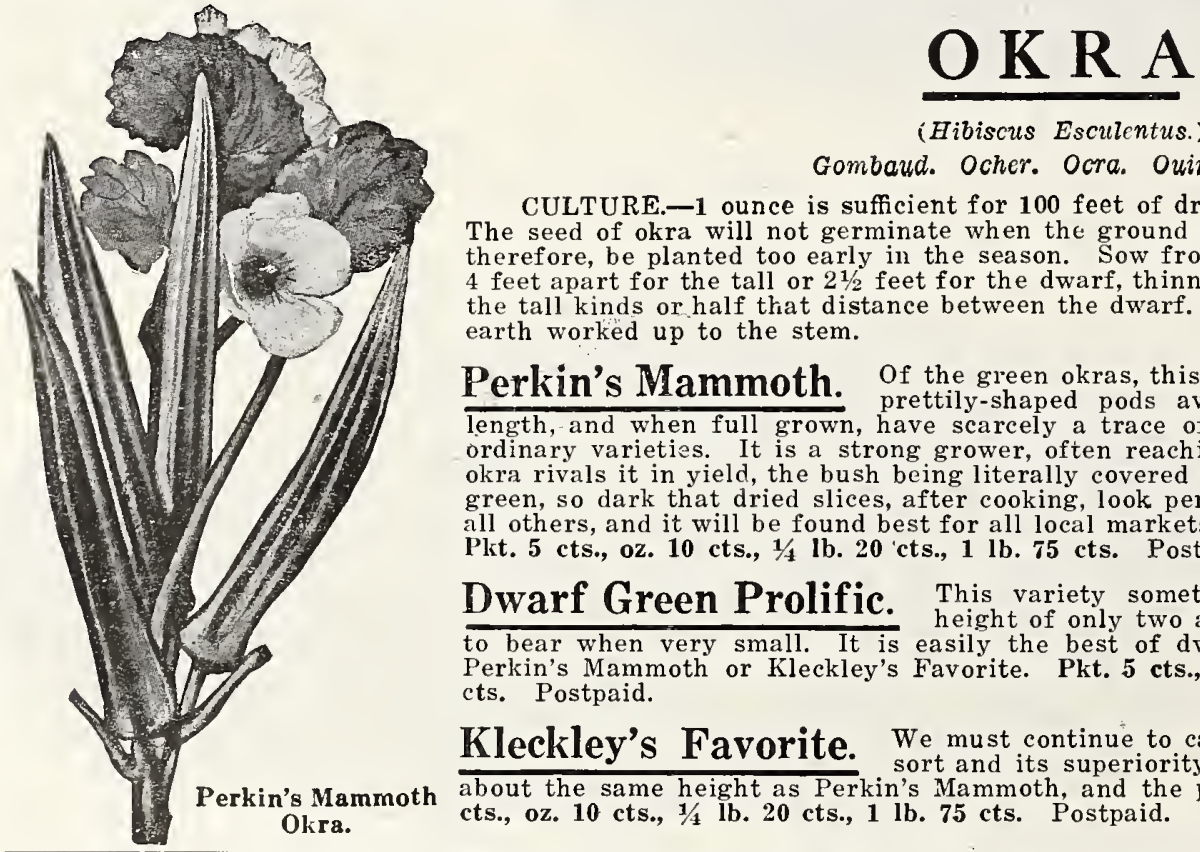

(Hibiscus Esculentus.)

Gombaud. Ocher. Ocra. Ouimbombo.

CULTURE.-1 ounce is sufficient for 100 feet of drill; 6 to 8 pounds will sow an acre. The seed of okra will not germinate when the ground is cold and wet, and it should not, therefore, be planted too early in the season. Sow from May to July 1 inch deep in rows 4 feet apart for the tall or $2 \frac{1}{2}$ feet for the dwarf, thinning to 1 plant every 3 feet between the tall kinds or half that distance between the dwarf. Cultivate frequently and keep the earth worked up to the stem.

Perkin's Mammoth. Of the green okras, this is easily the most valuable, as the erkins liammoth. prettily-shaped pods average more than four inches in length, and when full grown, have scarcely a trace of the woody fibre characteristic of ordinary varieties. It is a strong grower, often reaching over six feet in height, and no okra rivals it in yield, the bush being literally covered with pods. The color is an intense green, so dark that dried slices, after cooking, look perfectly fresh. Canners prefer it to all others, and it will be found best for all local markets which do not demand white okras. Plit. 5 cts., oz. 10 cts., $1 / 4$ lb. 20 cts., 1 lb. 75 cts. Postpaid.

Dwarf Green Prolific. This variety sometimes called Density, grows to a to to bear when very small. It is easily the best of dwarf okras, but not comparable to Perkin's Mammoth or Kleckley's Favorite. Pkt. 5 cts., oz. 10 cts., 1/4 lb. 20 cts., 1 lb. 75 cts. Postpaid. Kleckley's Favorite. We must continue to call attention to this splendid white about the same height as Perkin's Mammoth, and the pods are perfectly smooth. Pkt. 5 cts., oz. 10 cts., $1 / 1$ lb. 20 cts., 1 lb. 75 cts. Postpaid.

Remember we deliver free at catalogue prices-except where noted. Write for special prices in large quantitles. 


\section{ONION}

( Allium Cepa.)

ognon. Zwiebel. Cipollo. Cebolla.

CULTURE.-1 ounce is sufficient for 100 feet of drill; 4 to 6 pounds are sown to the acre in drills, 40 to 50 pounds to the acre for sets. Onions require a strong, rich and friable soil, which has been well manured for a previous crop, and cultivation must be thorough. The seed may be sown in February, March and April, in beds 4 feet wide, with the rows 10 inches apart, the drills drawn shallow, as the best onions grow on the surface. Sow very thickly, covering the seed about a $1 / 4$ of an inch, and pressing the earth down with the back of a spade or a roller. When well up, thin from 4 to 6 inches in the row and keep the beds well stirred until the young onions are started, after which it is well to hand-weed. In this latitude a good crop can generally be obtained by sowing in September or October in the way described, as they will grow until very cold weather and resume their growth in the spring. On account of the heat of our climate, large and perfect onions of the American varieties can rarely be grown from seed the first season, unless started in hot-beds, and the general practice is to raise the White and Yellow from "sets" planted in the fall and spring. Sets are obtained by sowing very thickly in drills one foot apart early in the spring, harvesting the crop when the tops have died, and storing them, thinly spread, in some dry, airy place. Tait's Norfolk Queen sets are usually set out in September or October, but other kinds are best kept out of the ground until February, although we find more and more tendency to plant both White and Yellow Globe in the fall. On transplanting have the shallow drills 10 inches apart and put the sets 4 to 6 inches apart. Both soot and salt may be advantageously applied to onion beds, and as is generally known, successive crops can be grown indefinitely upon the same ground.

Tait's Thoroughbred Norfolk Queen. This beautiful white onion we consider more generally desirable for Iait s Toroughbred Norfolk Queen. Southern growers than any other in our list, especially for market gardeners who make a specialty of "green onions." Our Norfolk Queen is not only attractive in appearance, but is extra early and large, perfectly matured bulbs being obtained from the seed in about four months. It is flattened in shape, but quite thick and beautifully symmetrical, the skin silvery white, the flesh snowy and of such tender sweetness that the raw onion may be eaten like an apple. Truckers from Maryland to Florida find it very profitable to bunch the young onions as soon as they are large enough to be marketable, and sell them thus, green, with the tops. It does not keep very well, and no attempt should be made to hold the crop very long after maturity. Pkt, $10 \mathrm{cts} ., 0 z .40$ cts., $1 / 4 \mathrm{lb} . \$ 1.25,1 \mathrm{lb}$. $\$ 4.00$. Postpaid.

Ailsa Craig. A variety becoming more popular each season. It is very similar to the Prizetaker in shape, color and A quality, but does not grow quite as large. Persons who like onions of the prizetaker type should grow some of this variety. Pkt. $10 \mathrm{cts.}$. $02.30 \mathrm{cts} ., 1 / 4 \mathrm{lb}$. $\$ 1.00,1 \mathrm{lb}$. $\$ 3.00$. Postpaid.

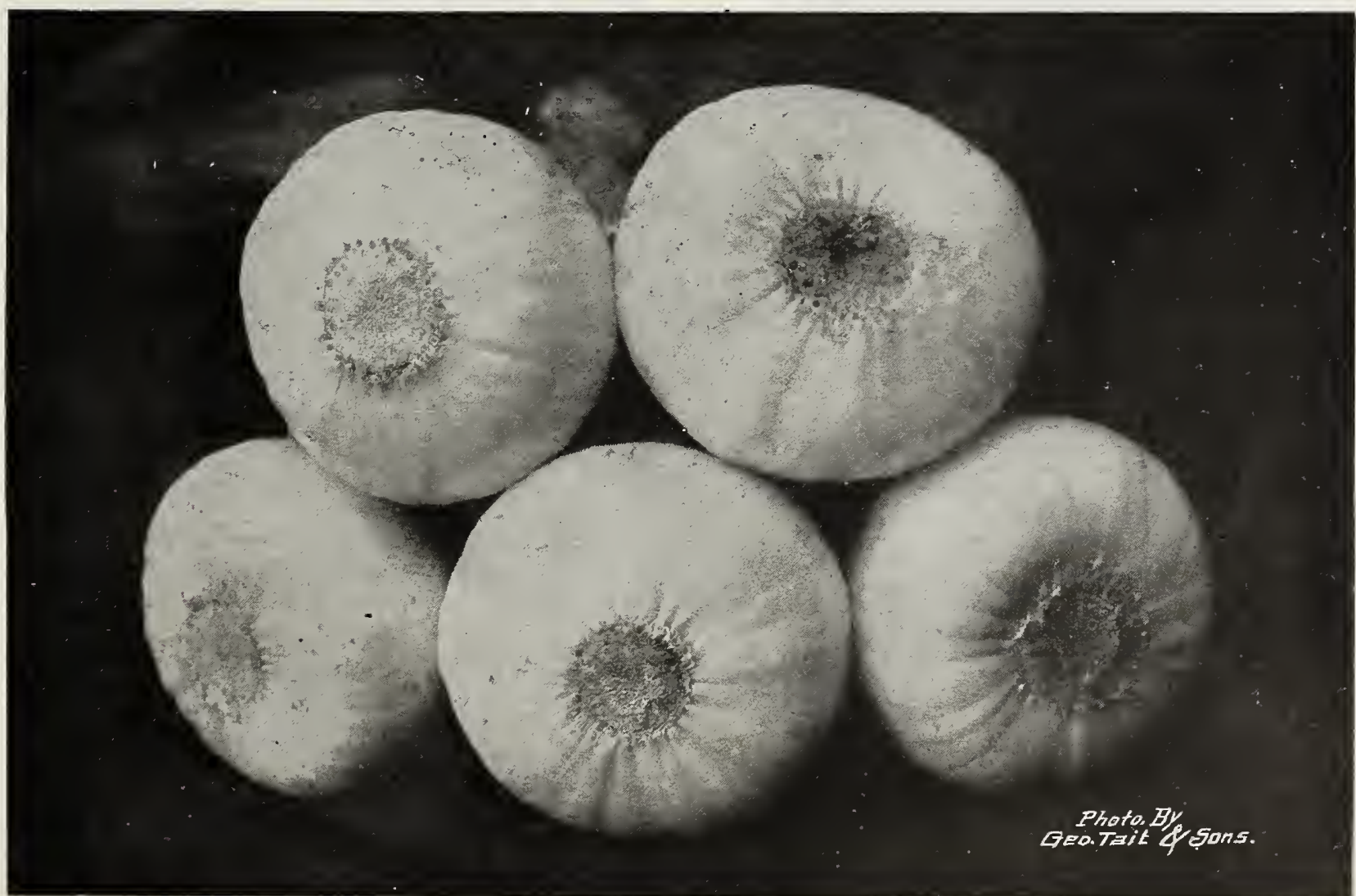

Tait's Thoroughbred Norfolk Queen Onion.

Remember we deliver free at catalogue prices-except where noted. Write for special prices in large quantities. 


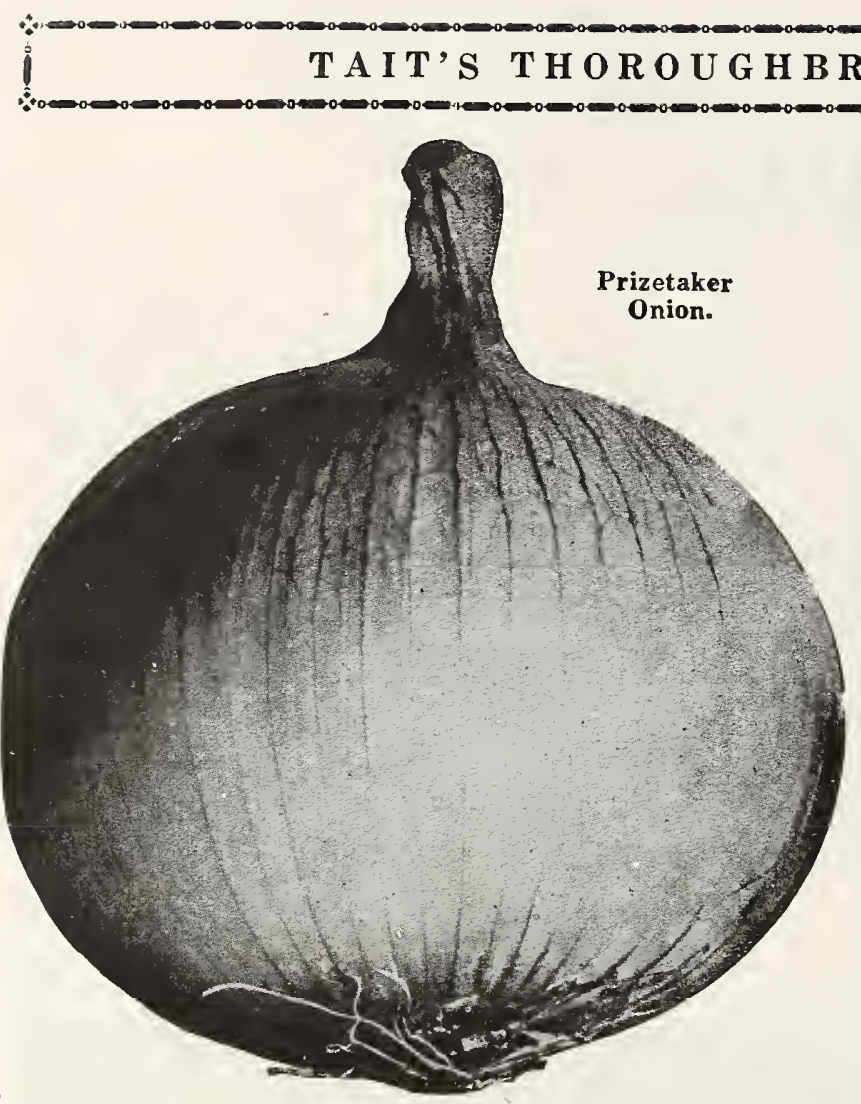

Southport White Globe. Although a little later maturing, this almost perfect onion is superior. Nearly spherical, pure white, solid as wood and fine of grain, it is one of the handsomest onions in cultivation, and for the main crop without a rival among the various white varieties. The quality being fully on a par with its appearance, every market has learned to appreciate and seek it, and it always brings the highest market price. Pkt. 10 cts., oz. 50 cts., $1 / 4$ lb. $\$ 1.50,1$ lb. $\$ 5.00$. Postpaid.

Southport Yellow Globe. Although a little Grobe. later than the Globe Danvers, this is distinctly superior, being a real Globe onion. The skin is a pale yellow, several shades lighter in color than the Danvers, and in size, as well as in form, it has a decided advantage. Pkt. 10 cts., oz. 50 cts., 1/4 lb. $\$ 1.50,1$ lb. $\$ 5.00$. Postpaid.

Southport Red Globe Onions of globular form Southport Red Globe. Onions of globular form the flat varieties and this is a splendid sort. The bulb has a rich, purplish red color, is almost as round as a ball, and keeps very well. We recommend it to those who prefer red onions. Plit. 10 cts., oz. 50 cts., 1/4 lb. $\$ 1.50,1$ lb. $\$ 5.00$. Postpaid.

Prizetaker. The remarkable size of this onion, averagPrizetaker. ing twelve or more inches in circumference, has made it one of the most popular varieties throughout the country. It is globe-shaped, rich straw color, very uniform in shape and size and phenomenally productive and of good quality. Pkt. $10 \mathrm{cts}$., oz. $50 \mathrm{cts}$., 1/4 lb. $\$ 1.50,1 \mathrm{lb}$. \$5.00. Postpaid.

Yellow Danvers. This has long been a standard vaellow Danvers. riety for all uses, its uniformity of shape, bright color and fine quality making it popular everywhere and it ranks very high in productiveness, but it is less handsome than the Southport Yellow Globe. Pkt. 10 cts., oz. 50 cts., $1 / 4$ lb. $\$ 1.50,1$ lb. $\$ 5.00$. Postpaid.

Silver Kino. The Mammoth White Garganus is the proper name of this handsome Italian variety-one of the largest NIII. onions in cultivation, often twenty inches in circumference and as much as four pounds in weight. Being a rapid grower it produces maxketable bulbs the first season. It is flattened in shape, but very thick and symmetrical, the skin silvery white, and the flesh peculiarly tender. Pkt. 10 cts., oz. 40 cts., 1/4 lb. \$1.25, 1 lb. \$4.00. Postpaid.

Crystal Wax. In the great onion-growing districts of Texas, this White Bermuda is a favorite variety, and it has been Crystal Wax. very profitable wherever introduced. Its beauty, size and extraordinary quality entitle it to the consideration of all Southern gardeners. It is of handsome flat shape, with a skin like polished silver. Pkt. 10 cts., oz. 50 cts., $1 / 4$ lb. $\$ 1.50,1$ lb. $\$ 5.00$. Postpaid.

\section{FROST PROOF ONION PLANTS}

Onion plants are becoming more popular each season for setting out in the spring, and are just as hardy as our frost proof cabbage plants and are shipped from our same growing station. We can supply Yellow Bermuda and Prizetaker from December to April.

\section{Cash Must Accompany All Orders For Plants}

Prices by Parcel Post, postage paid. In lots of 100, 200, 300, or 400 plants at 50 cents per 100 plants; 500 plants for $\$ 1.60 ; 1,000$ or more at $\$ 3.00$ per 1,000 plants.

Orders are filled by the 100 , not 250 or 350 . These prices are for even quantities of one variety to package; if you ordered 200 of one variety and 300 of another variety you would pay at the 100 rate.

Prices by Express, buyers paying express charges. In lots of 1,000 to 3,000 plants at $\$ 2.00$ per 1,$000 ; 5,000$ or more at $\$ 1.80$ per 1,000 . Plants packed for express shipment, 1,000 or 2,000 plants of a variety to package, they weigh about 25 pounds per thousand plants, packed for shipment.

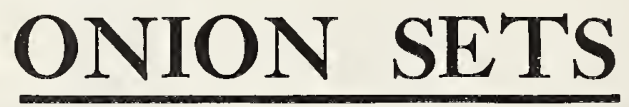

We quote all Onion Sets on the basis of $32 \mathrm{lbs}$. to the bushel. A pound equals about a quart.

CULTURE.-1 quart of onion sets of average size will plant 100 feet; for an acre 6 to 10 bushels in beds, or from 3 to 5 bushels in 18-inch rows. Plant the White, Yellow or Red Globe from February to May, or in the fall in rows 10 inches apart, allowing 4 to 6 inches between the bulbs, and as the best onions are those which grow on top of the soil, it is advisable to draw the drills very shallow. Sometimes, especially when planted in the autumn, the set will throw up a seed stalk, which must be promptly pinched out, or there will be no development of the bulbs. For the successful cultivation of this crop, rich soil and heavy fertilizing are absolutely necessary, and the beds must be kept clean. As the sets of our Norfolk Queen and Pearl deteriorate shortly after being taken from the ground, they must be planted from the middle of September to November, no stock of them being carried after that time. They grow rapidly, and, if set out the middle of September, the larger ones will be ready for use as green onions by Christmas.

Remember we deliver free at catalogue prices-except where noted. Write for special prices in large quantities. 
Tait's Thoroughbred Norfolk Queen. The most beautiful as it is the best flavored of all white onions. very earliest to mature. In order to secure these in quantity, it is always advisable to give us the order by the middle of September, our entire crop being often sold almost immediately upon arrival. Only in stock during September and October. Lb. 30 cts., 2 lbs. 55 cts., 4 lbs. 90 cts., 8 lbs. $\$ 1.50$. Postpaid.

White Globe. A well-known variety and a general favorite for the family garden and local markets. Lb. 25 ets., 2 lbs. Yellow Globe. In general usefulness the Yellow Globe is probably the very best for spring setting, as it ripens quite better than the White Globe, and is of finer quality than the Red Globe. Lb. 25 cts., 2 lbs. 45 cts., 4 lbs. 75 ets., 8 lbs. $\$ 1.35$. Postpaid.

Red Globe. Although much less desirable than the Yellow Globe, this old variety is still used to some extent here Red Globe. and there on account of its extraordinary keeping qualities. The flavor is extremely strong. Lb. 25 cts. 2 lbs, 45 cts., 4 libs. 75 cts., 8 lbs. $\$ 1.35$. Postpaid.

White Pearl. For setting out in the fall for green onions this is a popular sort, but much less desirable than our 25 "Norfolk White Queen," which is earlier and larger. Only in stock during September and October. Lb. 25 cts., 2 lbs. 45 cts., 4 lbs. 75 cts., 8 lbs. $\$ 1.35$. Postpaid.

Potato. Formerly grown in every Southern garden, this yellow multiplying onion is still used, but is being supplanted by \$1.35. the Yellow Globe. In stock only during September and October. Lb. 25 cts., 2 lbs. 45 cts., 4 lbs. 75 cts., 8 lbs.

\section{P A R S L E Y}

(A pium Petrosclinum.)

Persie. Petersilie. Prezamolo. Perejil.

CULTURE.-1 ounce is sufficient for 100 feet of drill; 3 pounds will sow an acre in drills 18 inches apart, or 5 pounds in drills 10 inches apart on beds that usually have 4 or 7 rows. Parsley seed is very slow in germinating, often requiring a month, and should be sown from February to August, in rich, mellow soil, $1 / 8$ of an inch deep, the surface being then made very firm. If the ground be covered with old bags after sowing, moisture is thus retained until the seeds have sprouted, while the effect of heavy rains is also prevented. With this precaution there is never any difficulty in securing a stand of parsley even during the heat of summer. Keep the weeds down by frequent hoeing, and when the plants get strong thin from 6 to 9 inches apart. During intensely cold weather, it is well to give the bed some slight protection of hay, grass or burlaps, to avoid damage by freezing. Market gardeners will find it profitable to sow Parsley in cold frames in August to winter over for early spring gathering.

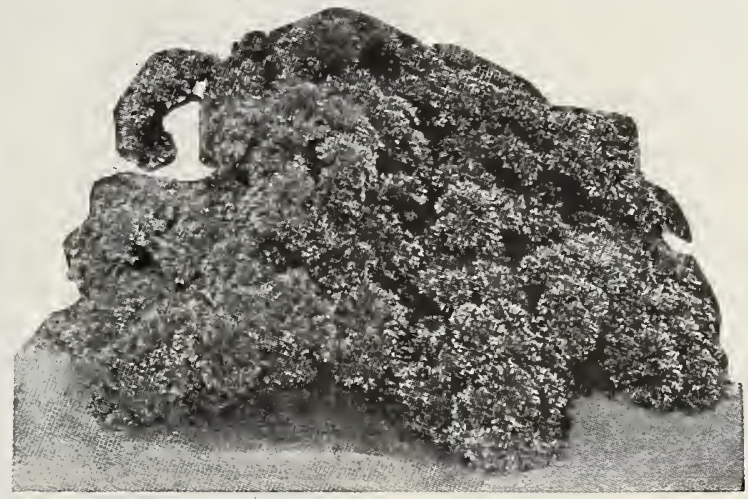

Tait's Thoroughbred Curled Scotch Parsley.

Tait's Thoroughbred Curled Scotch. For either market or the home garden we strongly recommend this 1arts. The color is very dark green and the leaves are most beautifully curled. Pkt. $10 \mathrm{cts.}$, oz. $15 \mathrm{cts} ., 1 / 4 \mathrm{lb} .40 \mathrm{cts} ., 1 \mathrm{lb}$. $\$ 1.25$. Postpaid

Fern Leaved. The foliage of this variety is as delicately divided as a fine fern. Pkt. 5 cts., oz. 10 cts., $1 / 4$ lb. 30 cts., 1 lb. 90 cts. Postpaid.

Moss Curled. Very densely curled, being very like some luxuriant moss, but not as dark as our Curled Scotch. Pkt. ed. 5 cts., oz. 10 cts., $1 / 4$ lb. 30 cts., 1 lb. 90 cts. Postpaid.

Plain. A strong, hardy plant, which is excellent for seasoning, but not so pretty for garnishing as the curled varieties. Plain. Pkt. 5 cts., oz. 10 cts., 1/4 lb. 25 cts., 1 lb. 90 cts. Postpaid.

Hamburg. A rooted variety that in growth resembles parsnips, and used for flavoring soups. Pkt. 10 cts., oz. 15 cts., $1 / 4$ lb. 40 cts., 1 lb. $\$ 1.00$. Postpaid.

\section{PAR S N IPS \\ (Pastinaca Sativa.) \\ Panais Pastinake. Pastinaca. Chirivia.}

CULTURE.-1 ounce is enough for 100 feet of drill; 4 to 6 pounds will sow an acre. Sow very thickly from March to August $1 / 4$ of an inch deep in drills 18 inches apart in deep, rich sandy loam, which has been well manured for a previous crop. When the plants are 2 to 3 inches high, thin out from 4 to 6 inches apart and cultivate frequently to keep down weeds. The roots, which are excellent for stock as well as for the table, are much improved in flavor by being left in the ground during the winter. As the seed does not germinate well in hot weather, sowing should be done as early as possible.

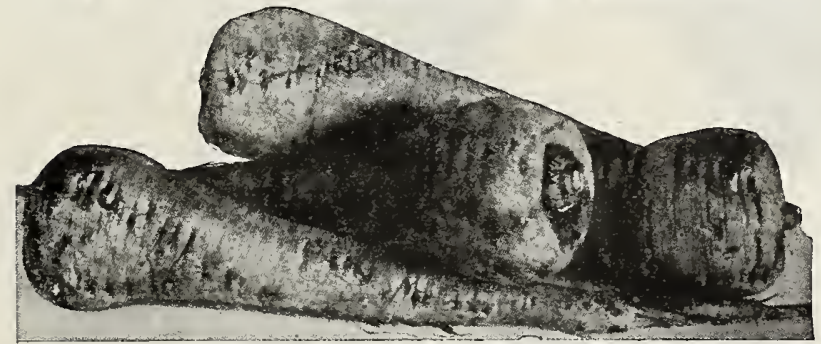

Improved Hollow Crown Parsnip.
Guernsey. This fine strain of parsnip, while not so long of the best quality, and is preferred by many on account of the ease with which the crop can be gathered. Pkt. 5 cts., oz. 10 cts., $1 / 4$ lb. 25 cts., 1 lb. 90 cts. Postpaid.

Student. Practically the same as Guernsey, described Improved Hollow Crown. Every one is familiar root easily distinguished from other winds by the depression at the top. The flesh is very sweet, particularly after frost has touched the roots, and the yield per acre is greater than that of shorter parsnips. Pkt. 5 cts., oz. $10 \mathrm{cts.}, 1 / 4 \mathrm{lb}$. 25 cts., 1 lb. 90 cts. Postpaid.

Remember we deliver free at catalogue prices-except where noted. Write for special prices in large quantities. 


\section{P E A S}

(Pisum Sativum.)

Pois. Erbsen. Pisello. Chicaroso-Guisante.

A pint weighs about one pound. Smooth seeded varieties weigh 60 pounds to the bushel, and wrinkled seeded varieties weigh 56 pounds to the bushel.

CULTURE-1 quart is sufficient for about 100 feet of drill; peas are sown in the drills at the rate of 1 to 2 bushels to the acre. Dry and moderatelv rich loam is best adapted to early peas, while heavy soil is preferable for the late sorts. As fresh, rank manure is apt to induce too heavy a growth of vine, manuring for the spring crop should be done in the previous autumn, or if deferred until the time of sowing, only thoroughly decomposed manure should be used. The early varieties a re usually planted about 2 inches deep, from the middle of January to the middle of March, wrinkled peas being so liable to rot if put in cold, wet ground they should not be sown before the latter part of February Dwarf varieties may be drilled in rows 18 irıches apart, but more space must be given to the kinds which make more vine, truckers usually allowing $2 \frac{1}{2}$ feet for the ordinary extra earlies. In the family garden, a good plan is to plant in double rows 6 inches apart, with 3 feet between the double rows. The late varieties do best when in rows far apari and with low - growing crops planted between. Com m ence cultivating when the peas are 2 inches high, and when the tendrils appear stick with brush and draw the earth up on each side to help in supporting the vine. Considerable profits are usually realized from a fall crop of peas planted between the middle of

August and the middle of September, and shipped in October or November, there being usually an active demand for them about that time. For this purpose the Thomas Laxton and Pilot are by far the best. As the reputation of our peas is taken advantage of by unscrupulous merchants to sell inferior stocks, our friends should be careful to see that any peas offered as Tait's should be in sealed containers.

\section{EXTRA}

EARLY

Tait's Thoroughbred Nonpareil.

The earliest and purest smooth pea in the world, much less showy than the World's Record, Dwarf Perfection or Laxton, but hardier than either. It is a single-picking pea amazingly uniform in ripening, an enormous yielder and more beautifully colored than any other, the clear, waxen green of the pods being so permanent that the Nonpareil may be held without injury for several days in case of temporarily depressed markets or a scarcity of pickers. The same advantage will, of course, appear when shipments are long in transit. Fine as the Nonpareil is, we do not, of course, claim that it is in the same class with Laxton, World's Record or Dwarf Perfection, these larger-podded varieties being well worth the difference in cost, since they are so easily picked and bring higher prices in market. Height $11 / 2$ feet. Pkt. 10 cts., $1 / 2$ lb. 25 cts., 1 lb. 40 cts., 2 lbs. 75 cts., 4 lbs. $\$ 1.25,10$ lbs. \$2.75. Postpaid.

Alaska. There are a great many stocks of this pea, origiAlaska. nally called "Laxton's Earliest of All," and the name means less than in the case of any other sort, some strains being fine selections, while others sold as Alaska are frequently worthless. When pure, it is one of the best extra earlies. Height, $1 \frac{1 / 2}{2}$ fcet. Pkt. 10 cts., $1 / 2 \mathrm{lb} .20$ cts., $1 \mathrm{lb}$. 35 cts., 2 lbs. 60 cts., 4 lbs. $\$ 1.00,10$ lbs. \$2.25. Postpaid.

Remember we deliver free at catalogue prices-except where noted. Write for special prices in large quantities. 

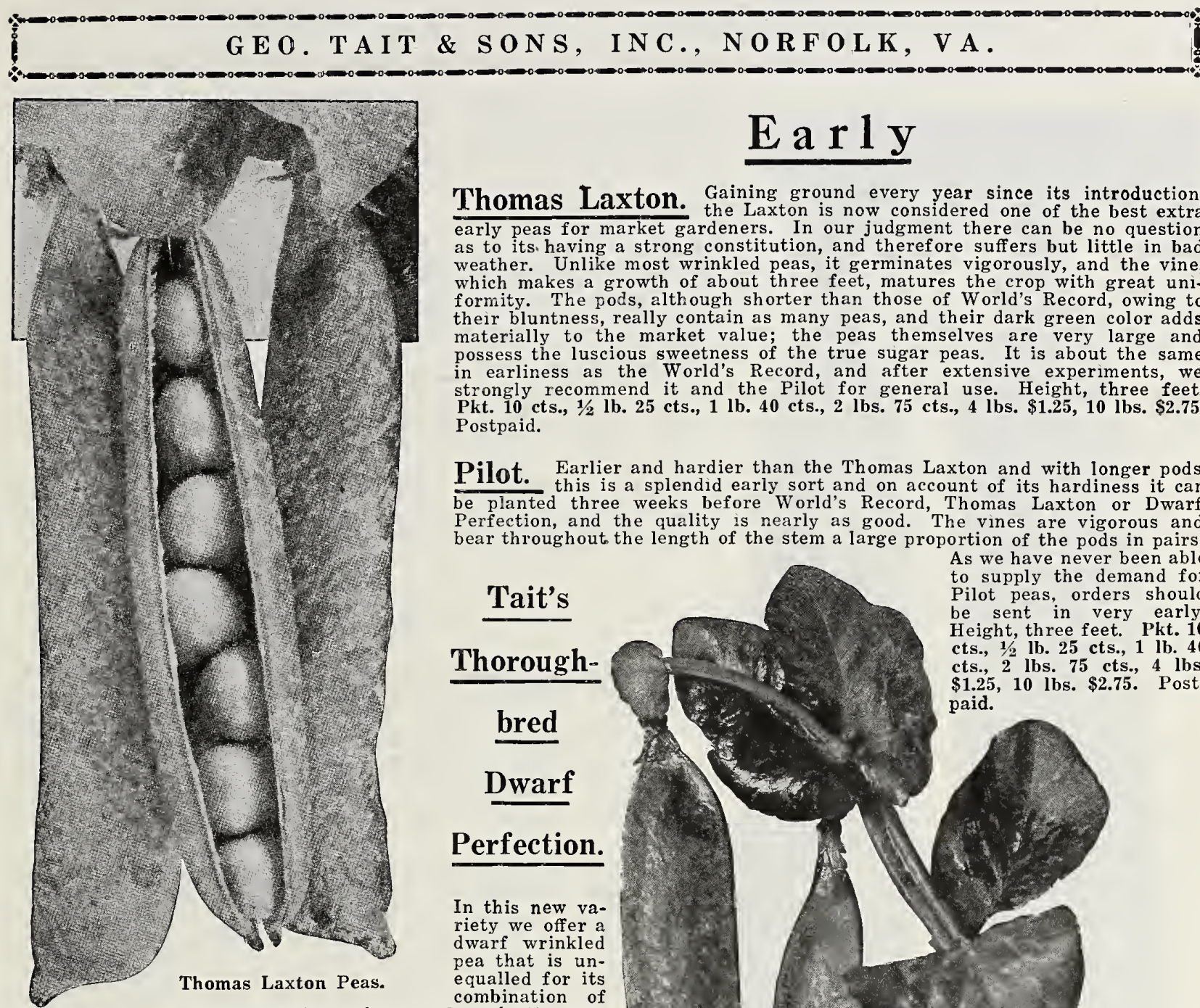

\section{Ear $1 \mathbf{y}$}

Thomas Laxton. Gaining ground every year since its introduction, early peas for market gardeners. In our judgment there can be no question as to its. having a strong constitution, and therefore suffers but little in bad weather. Unlike most wrinkled peas, it germinates vigorously, and the vine, which makes a growth of about three feet, matures the crop with great uniformity. The pods, although shorter than those of World's Record, owing to their bluntness, really contain as many peas, and their dark green color adds materially to the market value; the peas themselves are very large and possess the luscious sweetness of the true sugar peas. It is about the same in earliness as the World's Record, and after extensive experiments, we strongly recommend it and the Pilot for general use. Height, three feet. Pkt. 10 cts., $1 / 2$ lb. 25 cts., 1 lb. 40 cts., 2 lbs. 75 cts., 4 lbs. $\$ 1.25,10$ lbs. $\$ 2.75$. Postpaid.

Pilot Earlier and hardier than the Thomas Laxton and with longer pods, be planted three weeks before World's Record, Thomas Laxton or Dwarf Perfection, and the quality is nearly as good. The vines are vigorous and bear throughout the length of the stem a large proportion of the pods in pairs.
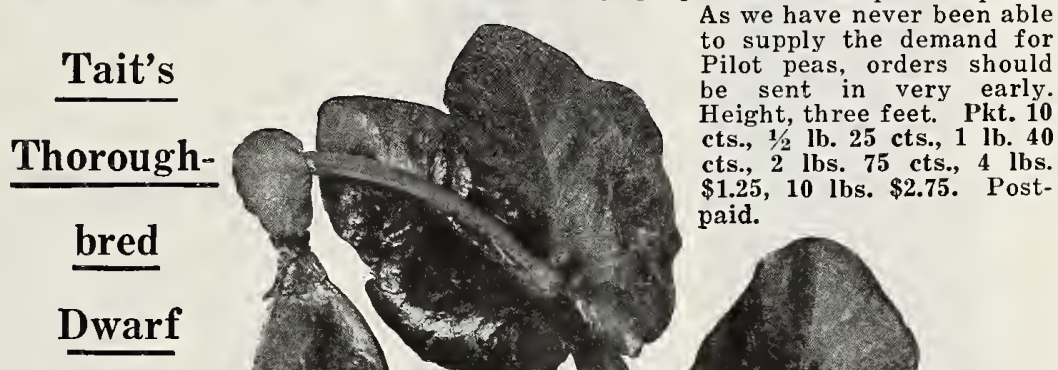

\section{Perfection.}

In this new variety we offer a dwarf wrinkled pea that is unequalled for its combination of extreme earliness, superb quality and unusual productiveness. The vines are hardy and vigorous, growing about 18 inches in height and carry really enormous quantities of large dark green pods, often measuring $4^{1 / 2}$ inches long, packed with eight or ten large luscious peas. Pkt. 15 cts., 1/2 lb. 30 cts., 1 lb. 50 cts., 2 lbs. 85 cts., 4 lbs. \$1.60, 10 lbs., \$3.25. Postpaid.

Laxtonian. A very fine dwarf early pea with unusually Laxtonian. large pods that are usually well filled with peas of splendid flavor. The vine grows about fifteen inches high and in appearance resembles closely Blue Bantam and Pioneer. Pkt. 10 cts., $1 / 2$ lb. 30 cts., 1 lb. 50 cts., 2 lbs. 85 cts., 4 lbs. $\$ 1.60$, 10 lbs. $\$ 3.25$. Postpaid.

World's Record. An improved Gradus, earlier and with Warker colored pods. It is almost as early as the standard extra early smooth-seeded sorts; is characterized by a sweetness unsurpassed by the finest of the wrinkled sugar peas; and on account of its immense pods invariably brings the highest price in all markets. Few things are perfect, and it must be admitted that the World's Record is open to criticism on account of its being less hardy than Thomas Laxton or Pilot. Height, three feet. Pkt. 10 cts., 1/2 lb. 25 cts., 1 lb. 40 cts., 2 lbs. 75 cts., 4 lbs. $\$ 1.25,10$ lbs. $\$ 2.75$. Postpaid.

Gradus or Prosperity. (See World's Record.) Admiral Beatty. A desirable new Fnglish variety of medium earlieight or nine large peas of delicious quality that are produced in great abundance. Height $3 \frac{1}{2}$ feet. Pkt. 15 cts., $1 / 2$ lb. 25 cts., 1 lb. 45 ets., 2 lbs. 80 cts., 4 lbs. $\$ 1.50,10$ lbs. $\$ 3.25$. Postpaid.

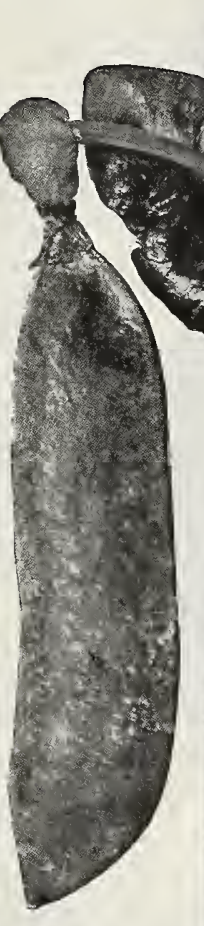
to supply the demand for Pilot peas, orders should be sent in very early. Height, three feet. Pkt. 10 cts., $1 / 2$ lb. 25 cts., 1 lb. 40 cts., 2 lbs. 75 cts., 4 lbs. $\$ 1.25,10$ lbs. $\$ 2.75$. Postpaid.

Remember we deliver free at catalogue priceg-except where noted. Write for special prices in large quantities. 


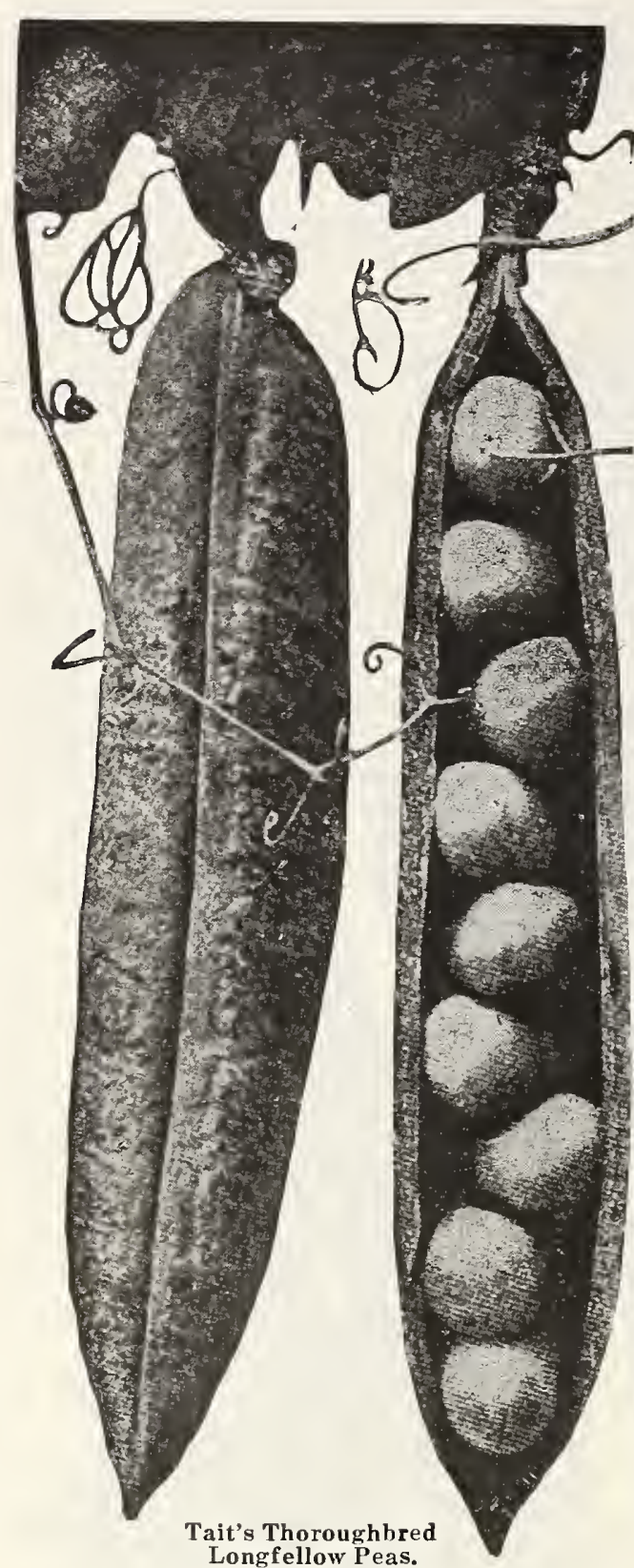

Long Pod Alaska. This exceedingly handsome, smooth seeded pea, hametimes called Ameer and Claudit, has a vine of extraordinary productiveness, and the pod always excite great admiration. Its extreme hardiness, like that of the Pilot, allows earlier planting than the wrinkled varieties. Height, 3 feet. Pkt. 10 cts., $1 / 2$ lb. 20 cts., 1 lb. 35 cts., 2 lbs. 60 cts., 4 lbs. $\$ 1.00,10$ lbs. $\$ 2.25$. Postpaid.

Prolific Early Market A smooth, white seeded variety that for spring sowing cannot compete as to , World's Record, Laxton or Dwarf Perpea-growers still use this variety, having found it dependable. Height, 21/2 feet. Pkt. $10 \mathrm{cts}$., 1/2 lb. 20 cts., 1 lb. 35 cts., 2 lbs. 60 cts., 4 lbs. $\$ 1.25,10$ lbs. $\$ 2.25$. Postpaid.

Little Marvel. A few days later than Laxtonian and with smaller sections, in our judgment it is not as desirable as Laxtonian or Dwarf Perfection. Height, 11/4 feet. Pkt. 10 cts., $1 / 2$ lb. 25 cts., 1 lb. 40 cts., 2 lbs. 75 cts., 4 lbs $\$ 1.25,10$ lbs. $\$ 2.75$. Postpaid.

Sutton's Excelsior. Ar English selection from the American variety, having a more vigorous vine and wearing found better than that Height, 1 foot. Pkt. 10 cts., $1 / 2$ lb. 25 cts., 1 lb. 40 cts., 2 lbs. 75 cts., 4 lbs. $\$ 1.25,10$ lbs. $\$ 2.75$. Postpaid.

\section{Late} Tait's Thoroughbred Longfellow. Gardeners who have extry this sort, as it is unquestionably of a peculiarly healthy constitution, resembling in this respect the standard smooth-seeded varieties. The pods are extremely long, straight and well formed, of the deepest green, and filled with large peas of delicious flavor. For an ideal succession, we recommend Nonpareil, Dwarf Perfection, Thomas Laxton and Longfellow. Height, 31/2 feet. Pkt. 10 cts., $1 / 2$ lb. 25 cts., 1 lb. 40 cts., 2 lbs. 75 cts., 4 lbs. $\$ 1.25,10$ lbs. $\$ 2.75$. Postpaid.

'Tait's Thoroughbred Magnum Bonum. Introduced by us Tait's Thoroughbred Magnum Bonum. many years ago. We have many customers who do not care to even try the newer kinds of peas, so firmly is this old stock rooted in their estimation, and indeed one can hardly wonder that this is the case. The Magnum Bonum has a vigorous vine, which produces immense pods and will, if supported by brush or trellis, continue longer in bearing than any other variety; the pods are really packed with large peas, and to the very end of the season the rich flavor is maintained. Height, 4 feet. Pkt. 10 cts., $1 / 2$ lb. 20 cts., 1 lb. 35 cts., 2 lbs. 65 cts., 4 lbs. $\$ 1.20,10$ lbs. $\$ 2.50$. Postpaid.

Telephone A standard variety, with large light green pods, but less Telephone. desirable than Longfellow or Magnum Bonum. Height, 4 lbs. \$2.50. Postpaid.

White Sugar Marrowfat. This sort has really little in common with either the Royal White or mely hardy, tremendously good flavor. being almost equal in quality to the wrinkled kinds. For canning there is nothing better, and those who supply local markets will find its beautiful pods very attractive to the buyers. Height, 3 feet. Pkt. 10 cts., 1/2 lb. 15 cts., 1 lb. 25 cts., 2 lbs. 45 cts., 4 lbs. 80 cts., 10 lbs. $\$ 1.75$ Postpaid.

\section{"C A B B A GE PEA S"}

(Edible Pods.)

Melting Sugar. An improved variety, which grows four or five feet high and produces an immense quantity of large Melting Sugar. broad pods of light color. It is very sweet and tcnder when young, and the pods are cooked like snap beans. Gardeners who have continued to grow the old "Cabbage Pea" are recommended to try the Melting Sugar, and we think they will admit the propriety of its attractive name. Height, 4 feet. Pkt. 10 cts., 1/2 lb. 20 cts., 1 lb. 35 cts., 2 lbs. 65 cts., 4 lbs. $\$ 1.20,10$ lbs. $\$ 2.00$. Postpaid.

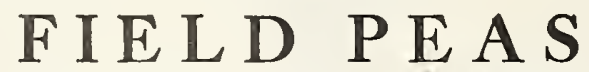

(See Index under "Miscellaneous Field Seeds.")

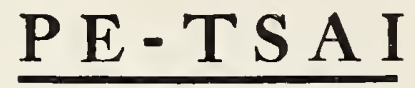

See Chinese Cabbage.

Remember we deliver free at catalogne prices-except where noted. Write for special prices in large quantities. 


\section{PEP P E R}

(Capsicum.)

Piment. Pfeffer. Peperone. Pimiento.

CULTURE.-1 ounce is sufficient for 100 feet of drill; 6 ounces will produce enough plants to set an acre. Sow $1 / 8$ of an inch deep in warm, mellow soil in May or June in rows $21 / 2$ feet, and when the plants are large enough, thin so as to leave 18 inches between them. Cultivate frequently to destroy weeds, and keep the earth worked up against the plant to assist the stem in carrying its weight of pods. If the seeds are sown indoors, so as to get the plants started early, srrangements must be made to have a uniform, high temperature. Market gardeners usually sow in hot-beds in February, transplanting into boxes or pots so as to have stocky plants ready for setting outdoors when danger of frost is past. Neapolitan. All market gardeners should plant a portion of their crop in this variety, which is a full week earlier It is very attractive in appearance, but much smaller in diameter than Ruby King or Worldbeater, and from three to four inches long; the color is vivid scarlet. The bush is very strong, and amazingly productive. Pkt. $10 \mathrm{cts}$. , oz. 40 cts., $1 / 4$ lb. $\$ 1.25,1$ lb. $\$ 4.00$. Postpaid.

Pimiento. The beautiful scarlet color, uniform shape, thick flesh and mildness have made this variety quite popular for market gardeners, canners and the home garden. It is especially good for salad, and for this purbe parboiled to remove the skin. Pkt. 10 cts., oz. 40 cts., $1 / 41$ b. $\$ 1.25,1$ lb. $\$ 4.00$. Postpaid.

Ruby King. This splendid, large, early pepper has been most profitable for market gardeners to plant for the main Ruby King. crop. The color is a little lighter than that of the old Bull Nose, and the flavor much milder. It may be eaten raw, prepared as tomatoes and cucumbers, or made into salads. Extremely productive. Special market gardener's strain. Pkt. 10 cts., oz. 35 cts., $1 / 4$ lb. $\$ 1.00,1$ lb. $\$ 3.50$. Postpaid.

Worldbeater. A recent introduction that we think superior to the Ruby King. It is a cross between the Chinese Giant Wrileat and Kul $\mathrm{King}$, and while quite as early as the Ruby King, is much larger. Flesh thick, mild and sort for either home or market gardeners. Special market gardener's strain. Pkt. 10 ets., oz. 40 cts., 1/4 lb. $\$ 1.25,1$ lb. $\$ 4.00$. Postpaid.

Sweet Spanish. This is one of the mildest kinds, and is used both for salad and in pickles. Pkt. 10 cts., oz. 40 cts.,

Long Cayenne. Well-known narrow, bright red pepper, which is generally dried and used in that condition for various

Chinese Giant. This is the largest pepper in cultivation, but rather late, and is a shy bearer. It is most brilliantly Colored, like the Ruby King, but in shape is nearly square, thicker and not so long. The thick flesh is so mild and sweet that it makes an excellent salad. While the bush rarely grows more than thirty inches high, it is remarkably strong of stem and branches widely like a dwarf tree. Pkt. 10 cts., oz. 60 cts., 1/1 lb. $\$ 1.75,1$ lb. $\$ 6.00$. Postpaid.

Sweet Golden Dawn. Very much like the Ruby King in shape and general appearance, but of a soft yellow color SWeet Golden Dawn. and with very mild flesh. Very productive, and previous to the introduction of the Neapolitan was the earliest large pepper. Pkt. 10 cts., oz. 40 cts., $1 / 4$ lb. $\$ 1.25,1$ lb. $\$ 4.00$. Postpaid.

Small Chili. The variety from which pepper sauce is made. The pod is red and exceedingly pungent. Pkt. 10 cts., Szall Chill. 40 cts., $1 / 4$ lb. $\$ 1.25,1$ lb. $\$ 4.00$. Postpaid.

Red Cherry. Named from its close resemblance to the cherry. It is used either as the Cayenne or as pickles. Pkt. . 10 cts., oz. 40 cts., $1 / 1$ lb. $\$ 1.25,1$ lb. $\$ 4.00$. Postpaid.

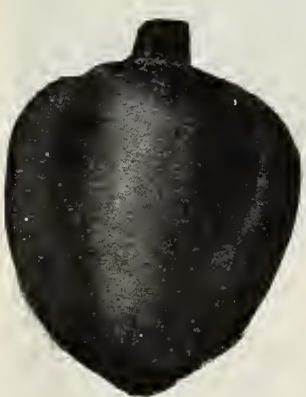

Pimiento.

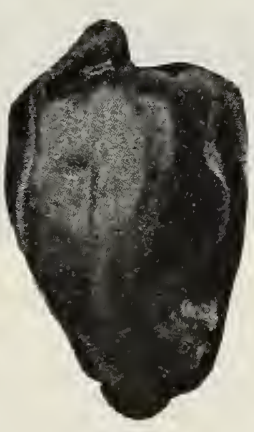

Neapolitan.

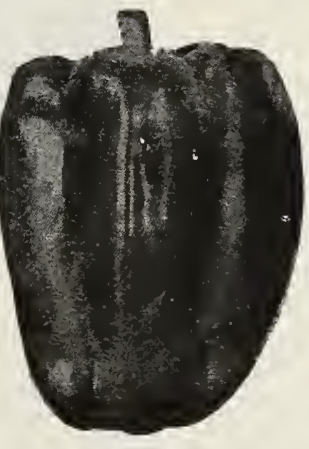

Worldbeater.

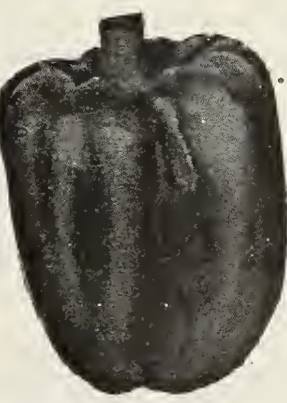

Ruby King.

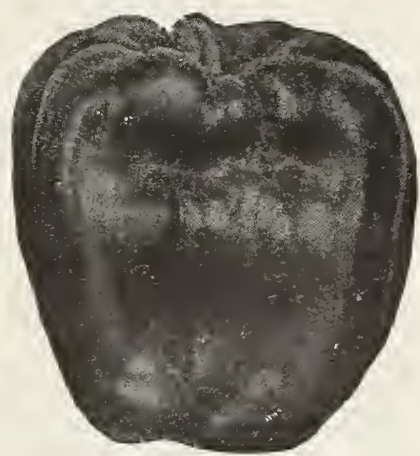

Chinese Giant. 


\section{POTATOES}

\section{Maine Grown Selected Stocks}

Prices of Potatoes are subject to change without notice and we require a deposit of $\$ 1.50$ per bag on all future orders.

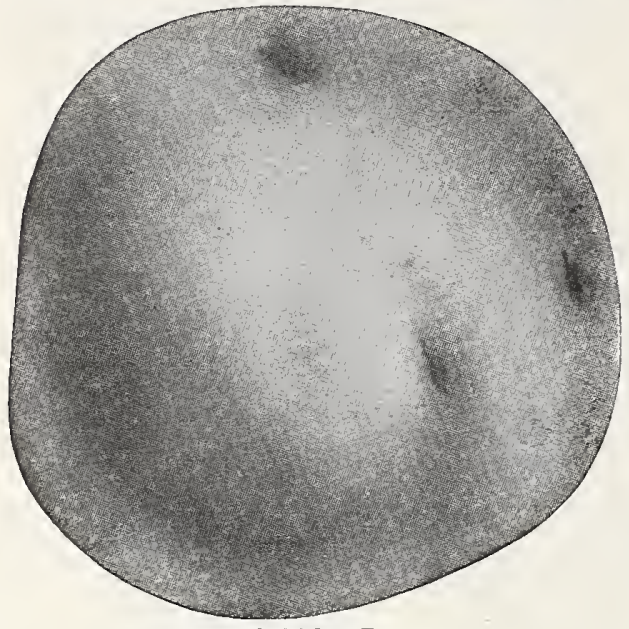

Irish Cobbler Potato.

Our Potatoes are grown by the best Aroostook county farmers, carefully inspected throughout the season, and stored in Maine under ideal conditions, and you will find our prices low when the quality of the stock is considered. Such stock cannot be sold for the same price as inferior seed picked up at random. We believe it will be to the interest of all potato growers to place their orders with a firm which for over fifty years has been devoted exclusively to the production of THOROUGHBRED SEEDS, and has created for Norfolk the reputation of having the highest standard for seeds in the United States.

CULTURE.-4 quarts, when the potatoes are properly cut, will plant a row of 100 feet, although by cutting to smaller pieces they can be made to go much further; 4 barrels are usually allowed to the acre, but potatoes with few eyes like the Irish Cobbler often require 5 . For early potatoes very early planting is necessary, truckers in Tidewater Virginia beginning with the first suitable weather in February, and heavy manuring is absolutely essential. A second crop may also be planted in July and August. Where possible, it is a great advantage to plant after clover, peas or similar humus-supplying crops. Furrows 4 to 6 inches deep should be made 3 feet apart, and unless potato fertilizer has been broadcasted, it should be drilled in the furrows at the rate of $40 \mathrm{lbs}$. to $100 \mathrm{yards}$, mixing it thoroughly with the soil. An excellent practice is to harrow in $20 \mathrm{lbs}$. of low-grade fertilizer 3 to 4 weeks in advance, finishing with $20 \mathrm{lbs}$. of high-grade at planting time. Drop the pieces about 12 to 15 inches and cover 3 or 4 inches. If planted early in February, they should be covered with 2 furrows. Late in March, when the sprouts have started but are still under the ground, the rows should be dragged to remove the excess of covering and put the surface in good condition. After the dirt has been turned away from each side of the rows, little need be done except to work it back again by successive cultivations, and to guard against blight and the potato bug. Paris green, either in solution or mixed with plaster, is used to kill the latter, and all really careful farmers now spray regularly with Bordeaux Mixture in order to ward off the former; by adding a little Paris green to the Mixture one operation will protect against both pests.

Trish Cobbler. The most popular early potato in the South and now more largely planted in this section than all Irish Cobbler. other kinds combined. It is a round potato and the flesh is white and of good quality. Our strain of this potato is really unique, and its purity produces a sensation among farmers who have been accustomed to cobblers which show from ten to thirty per cent of white blossoms. 5 lbs. 65 cts., 10 lbs. $\$ 1.20 ., 15$ lbs. $\$ 1.60$. Delivered.

\section{Bliss Triumph, or Red Bliss. Although less used} old extra early is still a favorite in certain sections, especially eastern North Carolina. It is a sure and heavy cropper. 5 lbs. 65 cts., 10 lbs. $\$ 1.25,15$ lbs. $\$ 1.60$. Delivered.

Dewdrop. A splendid early potato, and we find it popular bunched closely at the base of the plant, practically all being of marketable size, and of the best quality. A splendid variety for the home garden. 5 lbs. 65 cts., 10 lbs. \$1.25, 15 lbs. \$1.60. Delivered. CROP FAILED.

Houlton Early Rose (True.) No description is needed type of the old familiar Early Rose. 5 lbs. 65 cts., 10 lbs. $\$ \mathbf{1 . 2 5}$, 15 lbs. $\$ 1.60$. Delivered.

Green Mountain For the main crop this large ovalwhole shaped, medium late potato, on the whole, is probably the most satisfactory, as it is of exceptionally good table quality, and enormously productive, having few small tubers. 5 lbs. 65 cts., 10 lbs. $\$ 1.25,15$ lbs. $\$ 1.60$. Delivered.

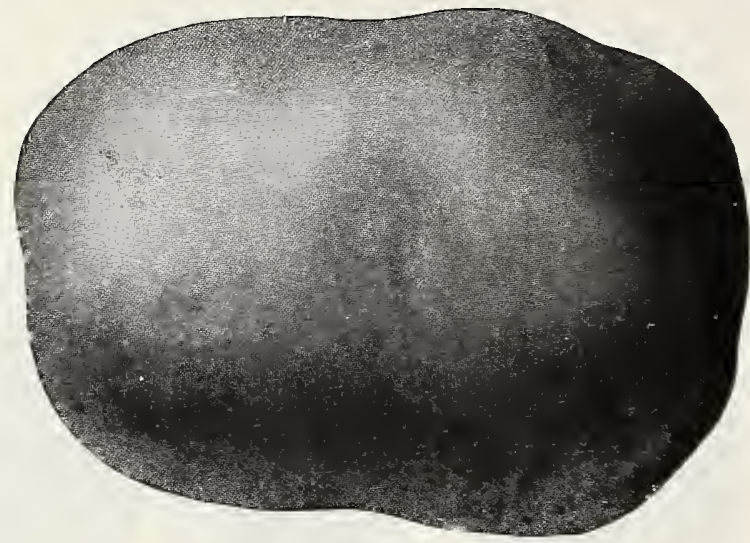

Green Mountain Potato.

Peach Blow An old favorite, for fall crop only, and planted from the middle of July to the middle of August. The pach Blow. skin is slightly tinged with pink, of an attractive appearance, and one of the best keepers, but of rather poor quality. The seed we offer is Northern grown, and free from disease. $5 \mathrm{lbs} .6 \mathrm{cts}$., 10 lbs. $\$ 1.20,15 \mathrm{lbs}$. $\$ 1.65$. Delivered.

Rehoboth. This variety, better known as "Hobo," is becoming very popular for fall crop. It looks somewhat like the \$1.60. Delivered Cobbler, a heavier yielder than the Peach Blow, and of better quality. 5 lbs. 65 cts., 10 lbs. $\$ 1.20$, 15 lbs.

Remember we deliver free at catalogue prices-except where noted. Write for special prices in large quantities. 


\section{P UMPKIN}

(Cucurbita Pepo.)

Potiron. Kurbis. Zucca. Caĩabaะa-Totanera.

CULTURE.-1 ounce is sufficient for a row of 100 feet in hills; for an acre in hills 2 to 3 pounds. Plant from May to July 1 inch deep in hills, 8 feet apart each way, and cultivate same as for squash.

Virginia Mammoth. While possessing the good characteristics able for its keeping qualities, specimens having been kept in good condition for nearly a year. It is oval in shape, grows to an immense size, and the thick flesh is of splendid flavor. Very productive. Pkt. $10 \mathrm{cts}$., oz. 15 cts., $1 / 4$ Ib. 40 cts., 1 lb. 1.50 Postpaid.

King of the Mammoths. This variety, often called "Jumbo," grow large pumpkins for exhibitions or their own gratification, as it attains an extraordinary size under the right conditions. Specimens have been grown weighing over a hundred pounds, and the quality is excellent. Pkt. 5 cts., oz. 10 cts., $1 / 4$ lb. 35 cts., 1 lb. $\$ 1.25$. Postpaid.

Connecticut Field. The small early field variety, too well known 1o need description. It is orange colored, (1) productive, and grown principally for stock. Pkt. 5 cts., oz. 10 cts., $1 / 4$ lb. 20 cts., 1 lb. 75 cts. Postpaid.

Large Cheese. A large, flat pumpkin of extra quality, justly popular Large Cheese. over the whole country. The color is a light reddish orange and the flesh is thick, fine of grain and sweet. Pkt. 5 cts., oz. 10 cts., $1 / 4$ lb. 20 cts., 1 lb. 75 cts. Postpaid.

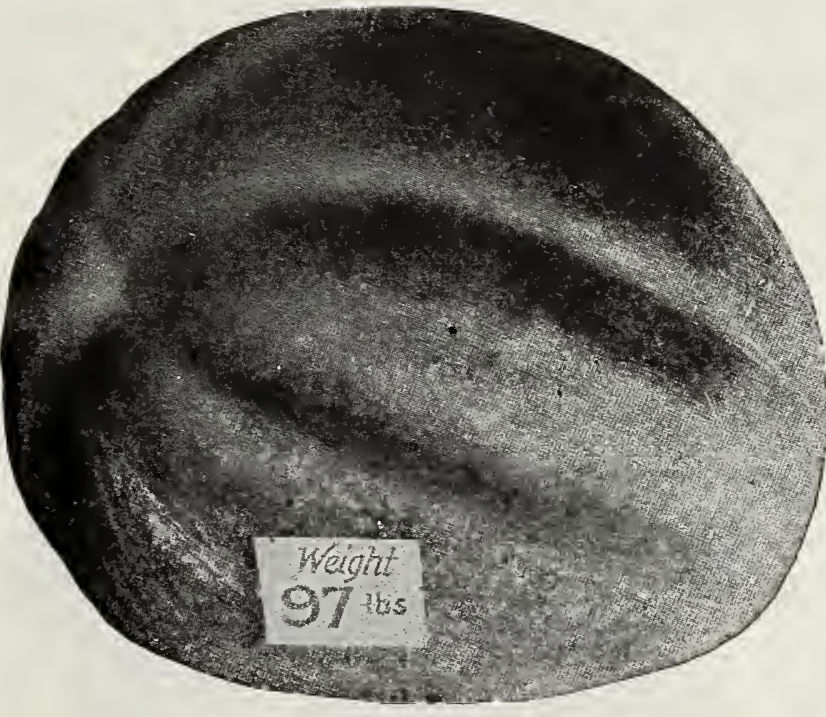

King of the Mammoth Pumpkin.

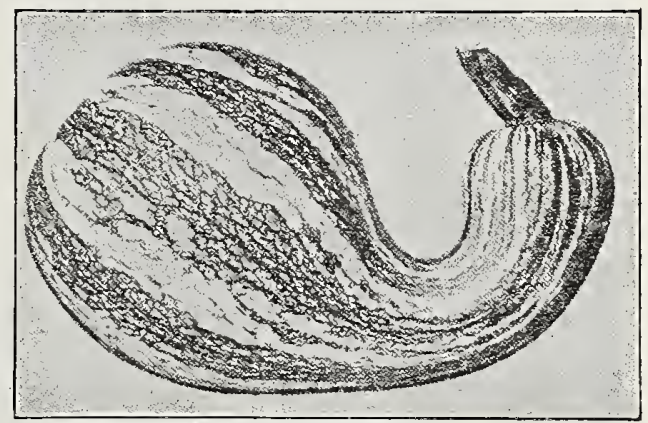

Striped Cashaw Pumpkin.

Cashaw. One of the standard old varieties, popular in spite of all the new introductions. It is light ripes, has a curved neck, hard skin, and very solid flesh. Pht. 5 cts., oz. 10 cts., $1 / 1$ lb. 35 cts., 1 lb. \$1.25. Postpaid.

Tennessee. A bell-shaped pumpkin of medium size, with creamy white, slightly ribbed rind; the flesh is peculiarly fine grained, very thick and dry, and makes delicious pies, the flavor generally being considered equal to the best sweet potatoes. Productive and a good keeper. Pkt. 5 cts., oz. 10 cts., 1/4 lb. 30 cts., 1 lb. $\$ 1.00$. Postpaid.

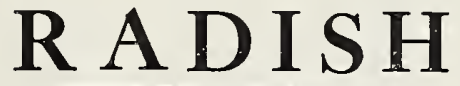

(Raphanus Sativus.)

Radis. Radies. Ravanello. Rabanito.

CULTURE.-1 ounce is sufficient for 100 feet of drill; 5 to 10 pounds will sow an acre in drills; broadcast; 15 pounds of long and 25 to 30 pounds of turnip are sown to the acre. The tenderness and sweetness of radishes are greatly dependent upon the rapidity of their growth, and they should not be sown upon cold and heavy soils. Dig the ground deeply and make it very rich with thoroughly rotten manure, since fresh manure induces forking of the roots and spoils the flavor. Sow out of doors, $1 / 2$ inch deep, from February to October, broadcast, in drills 18 inches apart, or on beds in 10-inch drills, or in drills 1 foot apart, thinning as needed. The early varieties being very hardy, will endure great cold before being killed, but as they are rarely good after having their growth checked, the beds should be covered in cold weather with straw or cedar brush. A very slight protection will be sufficient, especially if they are sheltered by fences or woods. Most varieties become pithy as soon as they are grown, so that successive sowings should be made every 2 weeks. The winter varieties are sown from the middle of July to the last of September and used as needed. Grown under glass or cottons. the quality of all radishes is wonderfully improved, and under this cultivation they may be sown at any desired time during the winter.

\section{Extra Early Globe Varieties}

Tait's Thoroughbred Favorite Forcing. The greatest value of this famous radish, introduced by us many pended upon the most favorable conditions it is possibie to grow this radish in four weeks. It is perfect in botli shape and color, the skin being a bright transparent red, and the shape nearly that of an olive, beautiful and wonderfully uniform. Its crispness and delicacy of flavor make it an excellent variety for sowing at intervals in the family garden. Never buy this radish except in sealed packages. Pkt. 5 cts., oz. 15 cts., $1 / 4$ lb. 30 cts., 1 lb. $\$ 1.00$. Postpaid.

Remember we deliver free at catalogue prices-except where noted. Write for special prices in large quantities. 
Tait's Thoroughbred Twenty-Day Forcing. This is undoubtedly the quickest growing radish in cultivaideal conditions in twenty days. The radishes are round, about $3 / 4$ of an inch in diameter, with very few short leaves and

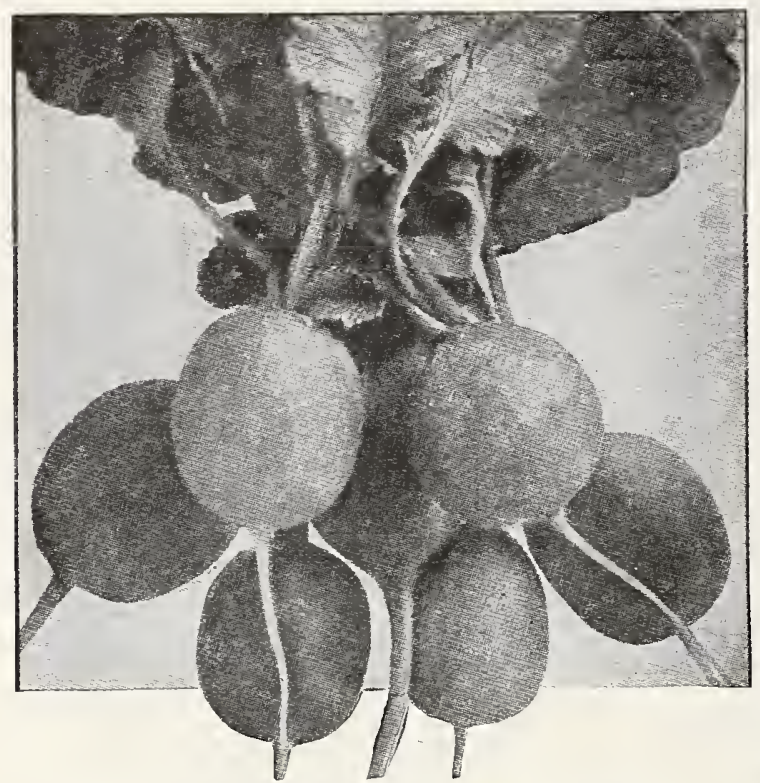

Tait's Thoroughbred Scarlet Globe Radish. of a brilliant red color. When pulled young, this radish is remarkably crisp and solid. Especially recommended for growing under glass. Pkt. 5 cts., oz. 15 cts., $1 / 4$ lb. 30 cts., 1 lb. $\$ 1.00$. Postpaid.

Non Plus Ultra An excellent extra early forcing radish. small tops and bright scarlet color. The flesh is crisp and well flavored. Pkt. 5 cts., oz. 15 cts., $1 / 4$ lb. 30 cts., 1 lb. \$1.00. Postpaid.

\section{Early Globe Varieties}

Tait's Thoroughbred Scarlet Globe. $\begin{aligned} & \text { Radish is one } \\ & \text { of our special- }\end{aligned}$ ties, and our Market Gardener's strain of this popular variety is unsurpassed. It is one of the most desirable radishes for field culture. It is very attractive in both shape and color, being a bright, transparent red and very smooth-skinned. Pkt. 5 cts., oz. 10 cts., $1 / 4$ lb. 25 cts., 1 lb. 90 cts. Postpaid.

White-Tipped Scarlet Turnip. A very handsome radish, ception of the tail, which is pure white. It and Searlet Globe are grown more largely than any other kind. Pkt. 5 cts., oz. 10 cts., $1 / 4$ lb. 25 cts., 1 lb. 90 cts. Postpaid.

Scarlet Turnip. Formerly the leading red radish grown by our Southern truckers for shipment, but now supplanted by Scarlet Globe, which is earlier, larger and of better

Sparkler. This is a new extra early, white-tipped, round radSparker. ish. It is distinet in that the white tip is larger and more pronounced than in any other sort. The proportions of white and red are distinctly shown on the root, the contrasting colors being so nearly equal gives a inost attractive appearance. Well adapted for either forcing in frames or private garden. Quality unsurpassed; remains solid and crisp a long time. Pkt. 5 cts., oz. 10 cts., $1 / 4$ lb. 25 cts., 1 lb. 90 cts. Postpaid.

White Box. The Philadelphia gardeners are partial to this turnip-shaped ket. It is a rapid grower, with brittle, sweet flesh and pure white skin. Pht. 5 cts., oz. 10 cts., 1/4 lb. 25 cts., 1 lb. 90 cts. Postpaid. French Breakfast. An olive-shaped variety and a great it is rich scarlet, from which color it shades gradually to white at the tip. It should be eaten when of medium size, and a good plan being to make sowings at intervals of five or six days. Pkt. 5 cts., oz. 10 cts., 1/4 lb. 25 cts., 1 lb. 90 cts. Postpaid.

Golden Summer. Oblong turnip-shaped, with heavy foliheat of summer. Although the skin is very thick and coarse in texture, the flesh is brittle and of good flavor. Pkt. 5 cts., oz. 10 cts., $1 / 4$ lb. 25 cts., 1 lb. 90 cts. Postpaid.

Giant White Stuttgart. This radish is possibly the sorts. The flesh is solid, crisp and pungent, and is much prized by those who like radishes of high flavor. While largely used as a summer radish, it may also be sown in July or August for fall use. Pkt. 5 cts., oz. 10 cts., $1 / 1$ lb. 25 cts., 1 lb. 90 cts. Postpaid.

\section{Long Varieties}

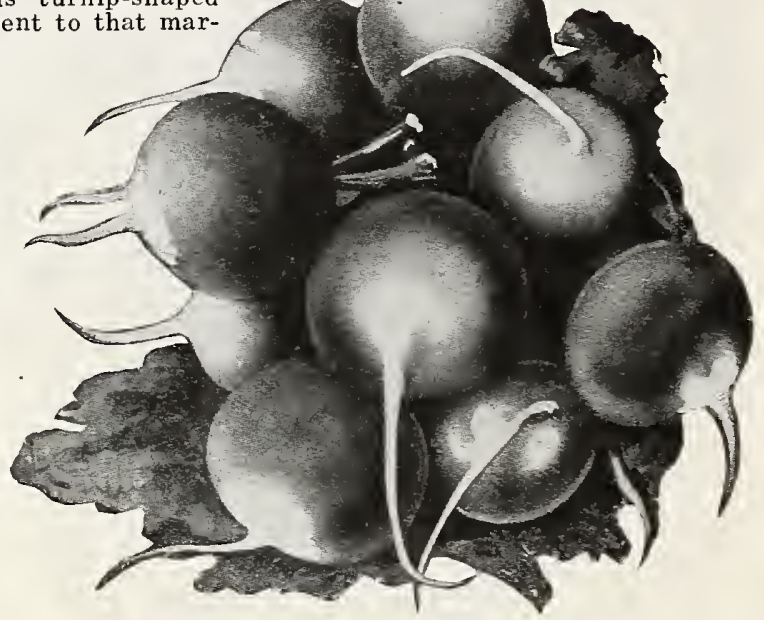

White-Tipped Scarlet Turnip Radish.

Cincinnati Market. This fine strain of Long Scarlet is often called the Glass Radish on account of its extraordiCincinati Market. nary brittleness, and we are sure it will be liked by all who try it. It is somewhat larger than the ordinary long variety, is of better color, and, remaining a long time in condition for the table, is, of course, especially good for family gardens. Pkt. 5 cts., oz. 10 cts., $1 / 4$ lb. 25 cts., 1 lb. 90 cts. Postpaid.

\section{Long Scarlet. (See Cincinnati Market.)}

White Icicle For forcing under glass this pure white long radish is very desirable, as it is of more rapid growth than Whe rimilar variety. The flavor is exceptionally good, and its brittle, delicately tapering root is weil suggested by its name. We do not hesitate to pronounce it the finest long white radish ever introduced. Pkt. $\mathbf{5}$ cts., oz. 10 cts., $1 / 4$ lb. 25 cts., 1 lib. 90 cts. Postpaid.

Remember we deliver free at catalogue prices-except where noted. Write for special prices in large quantities. 
Long White Vienna. The beautiful "Lady Finger" radish, formerly the finest outdoor long white radish, and still "Icicle." It is pure white, of pretty shape, and delicious flavor, but a week later than the White Strasburg. Pkt. 5 cts., oz. 10 cts., $1 / 4$ lb. 25 cts., 1 lb. 90 cts. Postpaid.

White Strasburg. This radish grows to a large size and remains The flesh is pure white, nearly transparent, and very pungent. For market use it is undoubtedly the best of its class, and those of our truckers who ship early white radish to Northern markets now use it almost exclusively. It is also a good summer sort, as it grows quickly and withstands hot weather. Pkt. 5 cts., oz. 10 cts., 1/4 lb. 25 cts., 1 lb. 90 cts. Postpaid.

\section{Long Keeping Winter Varieties}

Celestial. A variety which is really excellent for all seasons, and Celestial. particularly adapted to winter use. It is about the same shape and size as the well-known Long Black Spanish, but is much superior to it in every respect, being pure white, very smooth and thin skinned, juicy and wonderfully brittle. While pungent enough to satisfy most palates, it is at the same time quite sweet, and is peculiarly digestible. The tops when cooked are as good as turnip "greens," and the young radish can be used as a substitute for turnips. Market gardeners should lose no time in taking hold of it, for there is no other winter radish in its class. Pkt. 5 cts., oz. 10 cts., $1 / 4$ lb. 25 cts., 1 lb. 90 cts. Postpaid.

Sakurajima. Specimens of this giant Japanese variety often grow The quality is not so fine as some of the smaller kinds, but it is nevertheless much liked, and will probably become a standard winter radish. As it is not a rapid grower, the seeds should be sown not later than August, July being the best time. Pkt. 5 cts., oz. 10 cts., $1 / 4 \mathrm{lb} .35$ cts., $1 \mathrm{lb}$. $\$ 1.25$. Postpaid.

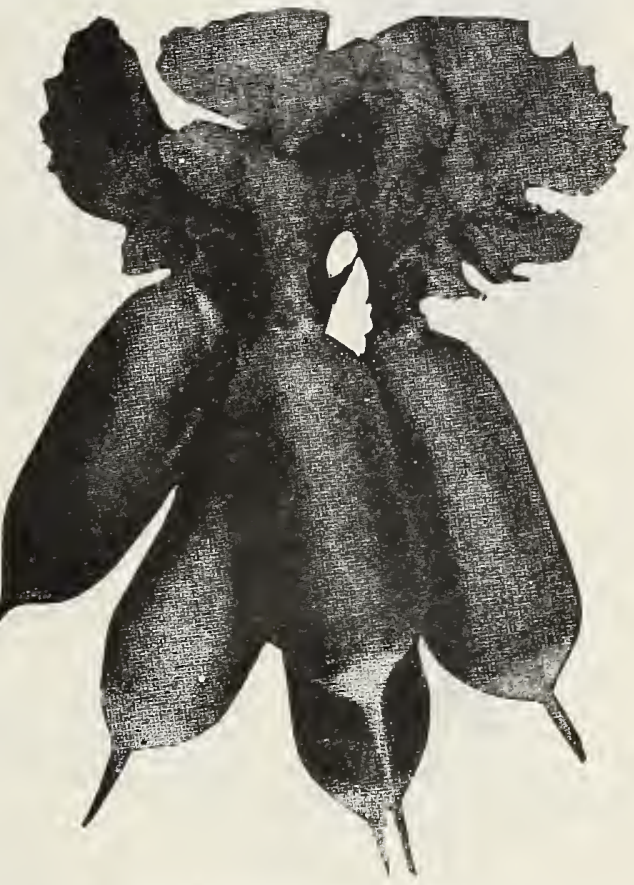

French Breakfast Radish.

Chinese Rose. Excellent for winter use, being of firm grain and pungent flavor, but much less desirable than the Celestial. The root is conical in shape and the skin a bright rose color. Pkt. 5 cts., $0 z .10$ cts., $1 / 4$ lb.

Round Black Spanish. A standard winter radish, which may be stored as successfully as any of the root crops. Round Black Spanish. It is a favorite with the Germans, nost of whom prefer radishes of strong rather than mild flavor. Pkt. 5 cts., oz. 10 cts., $1 / 4$ lb. 25 cts., 1 lb. 90 cts. Postpaid.

Long Black Spanish. Formerly the most popular of the winter radishes, but now less used than the newer varie1 lb. 90 cts. Postpaid.

\section{RHUBARB or PIE PLANT}

\section{(Rheum Hybridum.) \\ Rhubarbe. Rhabarber. Rhabarbaro. Ruibarbo.}

CULTURE.-1 ounce is sufficient for 100 feet of drill. For an acre, 8 to 10 pounds. Sow from the middle of March to middle of May, in deep rich ground, in drills a foot apart and $1 / 2$ inch deep, and when well up thin to 6 inches apart. In the fall trench a piece of ground at least 2 spades deep, manuring abundantly, and set the plants out 4 feet apart each way, covering with leaves or coarse manure. It is best not to gather many of the stalks the first season, and in our Southern country it is rarely successful except in shady situations. Perhaps the most profitable plan for Southern growers is to buy the roots-as offered below-setting them out in November, March or April. Rhubarb may be forced for early market, and large profits are realized by those who practice this method of cultivation. Entire clumps are taken from the open ground during the winter and set in cold frames or under the benches in hot houses, the yield being astonishing.

Myatt's Victoria. Very large, and although somewhat later than other varieties, the best for general use. For the

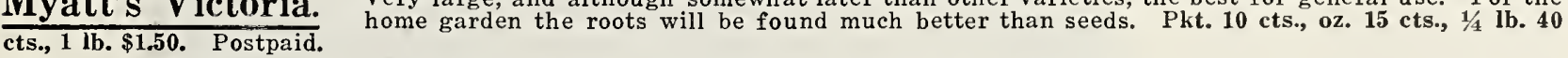

\section{RHUBARB ROOTS}

We can furnish fine Rhubarb Roots in any quantities in either fall or spring, but as they are carried in stock only during March and April, orders at any other time of the year should be sent a few days before roots are needed. Per doz. $\$ 3.00$. Delivered.

Remember we deliver free at catalogue prices-except where noted. Write for special prices in large quantities. 


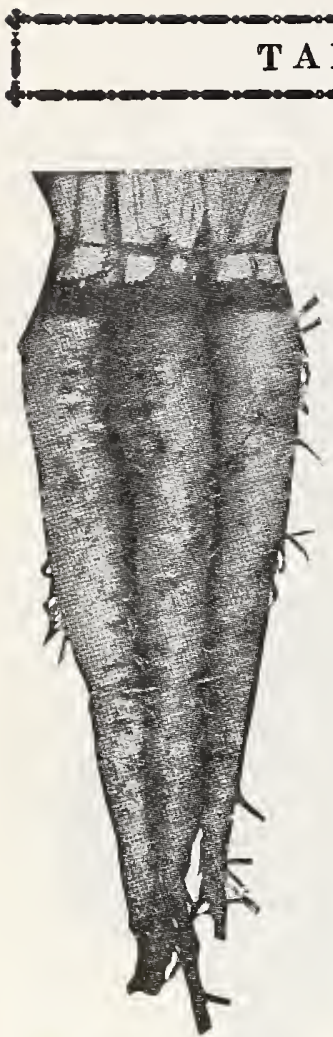

TAIT'S THOROUGHBRED VEGETABLE SEEDS

\section{SALSIFY or VEGETABLE OYSTER}

\section{Salsifi Blanc. Haferwurzel. Sassefrica. Salsifi blanco.}

CULTURE.-2 ounces are sufficient for 100 feet of drill, 6 to $8 \mathrm{lbs}$. to acre. Salsify delights in light, mellow soil which has been enriched for a previous crop, fresh manure having a tendency to induce side rootlets and forking. Sow from April to July thickly, in drills 18 inches apart, covering the seed half an inch, and when plants are up about an inch, thin from 3 to 6 inches apart. As the roots are perfectly hardy, they may be left in open ground all winter, care being taken to take them up before growth begins in spring. Applications of liquid manure in dry weather will prove very helpful.

Mammoth Sandwich Island. A greatly improved strain, very large and superior, of delicate although distinct flavor. The roots are so well shaped, size of the French Salsify and ket gardeners especially will find it most desirable, and will never sow the French after growing a crop of the Mammoth. Although comparatively few people have any idea of the value of Salsify, few vegetables are more nutritious and none more palatable, there being many ways in which it can be prepared so as to be hardly distinguished from real oysters. Pkt. 10 cts., $0 z .20$ cts., $1 / 4$ lb. 60 cts., 1 lb. $\$ 2.00$ Postpaid.

\section{S O R R E L \\ (Rumex Acetosa.) \\ Oscille. Sauerampfer Acetosa Acedera.}

CULTURE. - 1 ounce is sufficient for 100 feet of drill. For an acre, 1 to 2 pounds. Sow in drills $1 / 8$ inch deep and 18 inches anart in March or April, thinning from 4 to 6 inches. No special cultivation is required, as the plant is very hardy, but keep the flower stalks cut out as they appear.

Mammoth Lyons. A very wholesome salad, the taste for which is readily acquired, and Mannot Lyould be far more used in this country. Many who do not care for Sorrel as a dish will be delighted with the combination of Spinach and Sorrel, the peculiar acid of which greatly improves the Spinach. Pkt. 10 cts., oz. 15 cts., 1/4 lb. 40 cts., 1 lb. $\$ 1.50$.

Sandwich Island Salsify Postpaid.

\section{SPINAGH}

(Spinacea Oleracea.) Epinard. Spinat. Spinaccio. Espinaca.

CULTURE.-2 ounces are sufficient for 100 feet of drill. For an acre 5 to 10 pounds, if planted in rows 18 inches apart or 20 to 35 pounds if planted in ten-inch drills on beds that are usually either 4 or 7 feet wide. The latter is the method employed by our largest growers of spinach. As spinach cannot be grown upon poor land, manure heavily and trench deeply, liming being usually advantageous. For early use, sow from the middle of August until the middle of November, in drills not more than 1 inch deep. Although there is considerable danger of failure to get a "stand" if the weather is very warm, spinach being a cold weather plant, there is no other way of having it ready for use in December. The main crop should be sown during October, about the middle of the month if conditions are favorable. When the plants are started, begin thinning out until they are from 4 to 6 inches apart. For summer use, sow at intervals from February to April, after which all kinds except the New Zealand rapidly run to seed.

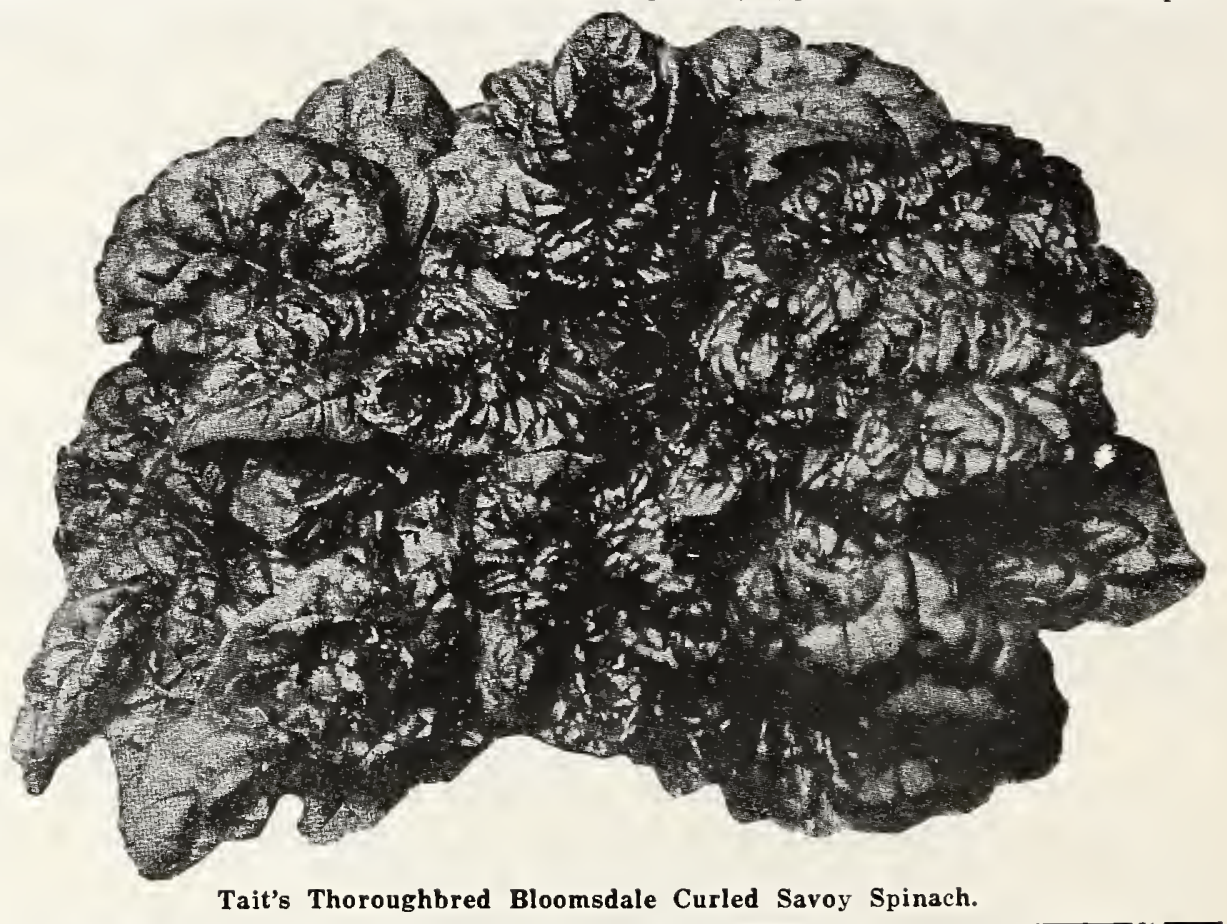

Remember we deliver free at catalogue prices-except where noted. Write for special prices in large quantities. 
Tait's Thoroughbred Bloomsdale Curled Savoy. The standard spinach for Southern market gardeners. The leaves are of the darkest green, and curled to perfection, retaining their peculiar crispness long after being cut and packed. As we are among the largest growers of spinach seed in the United States, we can, and invariably do, offer it at as low a price as is consistent with the quality of our seed. Oz. 5 cts., $1 / 1$ lb. 15 cts., 1 lb. 40 cts. Postpaid.

\section{Virginia Savoy - The Blight or Yellows Resistant Savoy Spinach. For many years growers}

folk have lost considerable money each season because of a disease in spinach commonly called "Spinach Blight," which often destroys whole crops. Several years ago the Virginia Truck Experiment Station at Norfolk began experiments to get rid of this disease, and after six years of hard work succeeded, by hybridization, in breeding a spinach that was practically "Blight Resistant," and which we have named Virginia Savoy. This variety should be used in preference to ordinary Bloomsdale Savoy in sections where "blight" is prevalent. Oz. 5 cts., 1/4 lb. 15 cts., 1 lb. 40 cts. Postpaid.

Late Seeding. This improved long standing variety is unquestionably the best spinach for spring sowing, as it is and of delicious quality, very productive and slower than any other kind to shoot to seed. The leaves are savoyed and very dark in color. Oz. 5 cts., $1 / 4$ lb. 15 cts., 1 lb. 40 cts. Postpaid.

New Zealand Summer. In the South ordinary kinds of spinach are worthless during the warm season, and there Le many gardeners who will be glad to welcome this introduction from New Zealand, since it endures heat wonderfully. Although used in the kitchen in the same ways as ordinary spirach, it is really entirely distinct, being a plant of considerable size with branches. It grows vigorously all the summer, and produces an astonishing amount of foliage, new leaves promptly taking the place of those which are cut, while the young branches are also edible, and may be cooked with the leaves. The leaf is very thick, soft and fleshy, and, like Savoy Spinach, extremely nutritious and digestible. The seeds germinate better and more quickly if soaked in warm water over night. Pkt. 5 cts., oz. 10 cts., 1/4 lb. 30 cts., 1 lb. $\$ 1.00$. Postpaid.

\section{Spinach Beet. (See Swiss Chard.)}

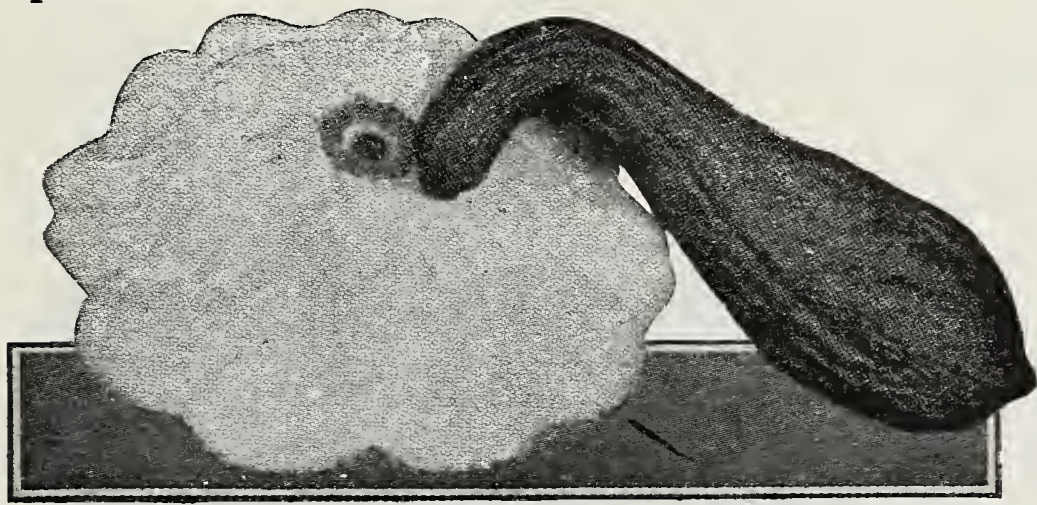

Silver Custard Squash.
Yellow Crookneck Squash.

\section{SQUASH}

(Cucurbita Meĩopepo.)

Courge. Kuchen Kurbis. Zucca. Calabaza.

CULTURE-1 ource is sufficient for 100 feet of drill. Sow 2 to 3 pounds of bush varieties or 1 to 3 pounds of the running, to the acre, in hills, or double the quantity if drilled, and thin to a stand. Sow from April to July in drills, or plant in hills 1 inch deep in the same manner as cucumbers and melons. The bush varieties should be about 3 feet a part each way, and the running kinds about 8 feet. When the plants are up, thin so as to leave 3 of the strongest plants, and cultivate to keep free of weeds.

\section{BUSH VARIETIES}

Prolific Early White Bush. Every market gardener who grows "cymblings" should plant a portion of his crop source of great profit to Southern growers. The flesh is finely grained and of good flavor, but it is not nearly so large or so showy as the Silver Custard. Pkt.10 cts., oz. 15 cts., $1 / 4 \mathbf{l b . 4 0}$ cts., 1 lb. \$1.50 Postpaid.

Tait's Thoroughbred Silver Custard. This squash is an immense improvement over all other varieties of most double White Bush "Cymbling." It is considerably earlier as well as almost double the size of the old kind, and is at the same time handsomer and of better quality. As pure stocks of White Bush are very uncommon, we are confident all market gardeners will be delighted with this. Pkt. 5 cts., oz. 10 cts., $1 / 4$ lb. 30 cts., 1 lb. \$1.00. Postpaid.

Golden Custard. Those who prefer the yellow bush squash will find this the best for their use, as it is decidedly ity. Pkt. 5 cts., oz. 10 cts., $1 / 4$ lb. 30 cts., 1 lb. $\$ 1.00$. Postpaid.

Cocozelle This bush variety, sometimes called "Italian Vegetable Marrow," produces oblong squashes often a foot in Cocozelle. length, handsomely mottled, dark and light green, and the flesh is of extremely good quality. Pkt. 5 cts., oz. 10 cts., $1 / 4$ lb. 30 cts., 1 lb. $\$ 1.00$. Postpaid.

Remember we deliver free at catalogue priceg-except where noted. Write for special prices in large quantities. 

Mammoth Yellow Summer Crookneck. Valuable for early crop, and the best and richest summer bush crescences, the shell becoming exceedingly hard when ripe. Pkt. 5 cts., oz. 10 cts., 1/4 lb. 30 cts., 1 lb. $\$ 1.00$. Postpaid.

\section{Running Varieties}

Delicata. Whether for summer or fall use this small but very prolific, early-running squash will be found excellent. Dne fruit is oblong, orange yellow, striped with green, the flesh being richly flavored, as dry as the Hubbard, and keeps well. Pkt. 5 cts., oz. 10 cts., $1 / 4$ lb. 30 cts., 1 lb. $\$ 1.00$. Postpaid.

Orange Marrow For a number of years this fine squash-a great improvement upon the Boston Marrow-has Hange Marrow. been only partially appreciated, but we note that it is now taking the prominence to which it has always been entitled. It is perhaps the most delicately flavored of all, and is especially valuable to truckers on account of its earliness. It is remarkably prolific, and we recommend it for both the early and late crops. Pkt.5 cts., oz. 10 cts., 1/4 lb. 30 cts., 1 lb. $\$ 1.00$. Postpaid. Boston Marrow. An old standard variety, with thin skin of deep orange, mottled with cream when ripe. Our strain common stocks sold at low prices. Pkt. 5 cts., oz. 10 cts., 1/4 lb. 25 cts., 1 lb. 90 cts. Postpaid.

Delicious. All who care for winter squash will admit that this variety has been well named. It is not yet perfectly Delicious. uniform in size and coloring, but can be commended as perhaps the sweetest and best grained of all table squash. The weight runs from five to ten pounds each, the skin is dark green and the flesh, which has remarkable thickness, is a dark orange. Pkt. 5 cts., oz. 10 cts., $1 / 1 / 1$ lb. 30 cts., 1 lb. $\$ 1.00$. Postpaid.

Chicago, or Warted Hubbard. Of superior quality and largely used in the Northern States, as it may be kept Chicago, or Warted Hubbard. through the winter. The shell is a bronzed green, sometimes shaded with yellow and orange with orange-yellow flesh, and is of splendid quality. Pkt. 5 cts., oz. 10 cts., $1 / 4$ lb. 30 cts., 1 lb. $\$ 1.00$. Postpaid.

Golden Hubbard. Practically the same shape as the Chicago Warted Hubbard, but smaller. The skin is yellow with 1 lb. \$1.00. Postpaid. flesh deep golden yellow, of rich flavor and cooks very dry. Pkt. 5 cts., oz. 10 cts., 1/4 lb. 30 cts.,

Mammoth Chili. With extra care this orange-yellow, smooth-skinned squash will attain a really enormous size, 1anno specimens having been grown weighing nearly a hundred pounds. It is of good quality, the flesh being extra thick, sweet and very fine grained. Pkt. 5 cts., oz. 10 cts., $1 / 1$ lb. 35 cts., 1 lb. $\$ 1.25 . ~ P o s t p a i d$.

\section{Swiss Chard or Spinach Beet}

CULTURE.-Same as that for Beets. This variety of Beet is not grown for its roots, the valuable part of the plant being its leaf, the midrib of which is cooked in the same way as asparagus, and the rest is used as spinach, and is quite as good. Its tenderness and delicacy of flavor are dependent to a considerable degree upon the cultivation, and especial care must be given in keeping down weeds. It should be much better known, as it is a very wholesome vegetable, more productive than Spinach and far more easily grown in warm climates. It is often called Spinach Beet.

Lucullus. This mammoth variety we consider the with eaves and stalks as thick and nearly as broad as those of Rhubarb. Pkt. 5 cts., oz. 10 cts., 1/4 lb. 35 cts., 1 lb. \$1.25. Postpaid.

\section{Vegetable Marrow}

Those who like the Scallop Squash or Cymbling should try the Vegetable Marrow. Although not widely known in America, it is very highly esteemed by the English, and when better known in our country will be more appreciated. The squashes, which resemble a very large cucumber in shape, have white flesh of distinctive meltirg flavor. They can also be saved and used as Winter Squash.

Long White Running. This selected strain bears squashes of mects., 0z. 15 cts., $1 / 4$ lb. 50 cts., 1 lb. $\$ 1.75$. Postpaid.

\section{Spring Sprouts}

See KALE.

Remember we deliver free at catalogue prices-except where noted. Write for special prices in large quantities. 


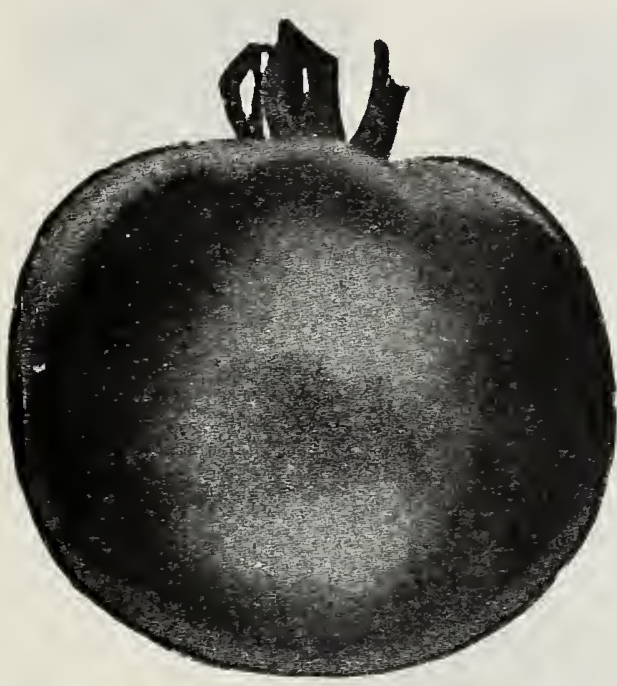

Pink Globe Tomato

\section{TOMATOES}

(Solanum Lycopersicum.)

Tomate or Pomme dAmour. Liebesapfel. Pomo d'oro. Tomate.

CULTURE.-1 ounce is sufficient for 100 feet of drill; 4 ounces will produce enough plants to set an acre. The tomato flourishes best in warm, light soil, moderately rich. For early use sow $1 / 8$ of an inch deep in January or February in a hot-bed, or, if only a few plants are wanted, they may be sown in a window box. In order to get the plants strong and stocky, they should be transplanted when 2 to 3 inches high, and a second transplanting later on will add greatly to their stockiness. When all danger of frost has passed, set out in the open ground in rows 3 feet apart, leaving the same distance between the plants, and if convenient, furnish a support for the vine. For later crops sow in the open ground as above directed. Or sow 5 to 6 seeds at intervals of 3 feet in rows the same distance apart, where they are to remain. After danger from insects is past thin to one strong plant. This does away with transplanting at the most trying season of the year. Tomatoes succeed so much better when they are supported by brush, or trained to a trellis, that we strongly recommend all amateur growers to adopt the latter method in their gardens. A great deal of room can be saved, and rotting of the fruit almost entirely prevented. The trellis should be made about $4 \frac{1}{2}$ feet high, with horizontal slats not more than 18 inches apart. The posts must be very firmly set in 'the ground, as the weight when the vines are in full bearing is greater than might be supposed. Regular spraying with Bordeaux will prevent blight, which otherwise is liable to seriously injure the vines.

\section{With Deep Pink Skin}

June Pink. The earliest Pink Tomato and a splendid sort for market gardeners. The fruit is of medium size, smooth, in the home garden. Pkt. 10 cts. oz. 40 cts., $1 / 4$ lb. $\$ 1.25,1$ lb. $\$ 4.00$. Postpaid. Cooper's Special. Known to Florida growers as being a self topper or self pruner, from its characteristic growth. color it is very much like Globe, but the vine is shorter and the fruit matures a few days earlier. Pkt. 15 cts., oz. 75 cts., 1/1 lb. $\$ 2.00,1$ lb. $\$ 7.50$. Postpaid.

Pink Globe In the far South this variety is considered the most profitable to grow. It is early, medium sized, prolific, Pink Globe. and colors up handsomely after picking; a desirable quality for long distance shipping. Our strain is "Thoroughbred." Pkt. 10 cts., oz. 50 cts., $1 / 4$ lb. $\$ 1.50,1$ lb. $\$ 5.00$. Postpaid.

Early Detroit. This is one of the best of the are vigorous, very productive, and do not easily blight. The fruits are smooth, nearly globe shaped, firm, and of excellent quality. While bred for a shipping Tomato it is equally as good for the home garden. We specially recommend it for late crop. Pkt. 10 cts., oz. 30 cts., $1 / 4$ Ib. $\$ 1.00,1$ lb. $\$ 3.00$. Postpaid.

Tait's Thoroughbred Norfolk. A splendium early variety with smooth skin and brilliant deep purplish. pink coloring. It has been carefully bred, is remarkably free from blight, and seldom cracks. It should satisfy e very one who seeks a combination of size, beauty, quality, and p r od uctive ness. "Tait's Norfolk" and "Early Detroit" are the two pink skinned varieties preferred by the market gardeners around Norfolk for the fall crop. Pkt. 10 cts., oz. 35 cts, $1 / 4$ lb. $\$ 1.00,1$ lb. $\$ 3.50$. Postpaid.
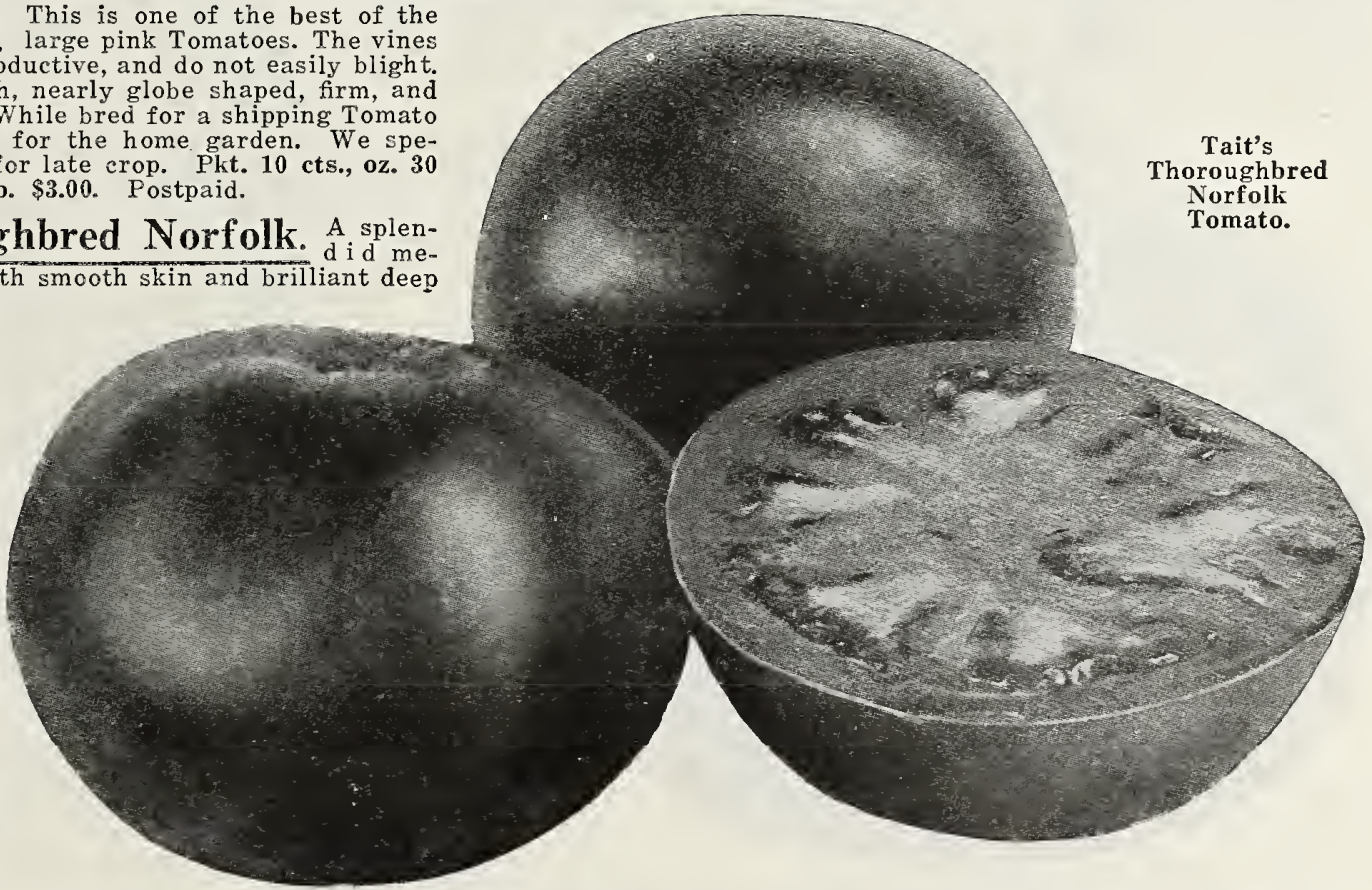

Remember we deliver free at catalogue priceswexcept where noted. Write for special prices in large quantities. 
Brimmer. While not an early sort, it is fairly weigh a pound or more, and the quality is grown to Should be grown only for local markets or family use. Pkt. 10 cts., oz. 60 cts., $1 / 4$ Ib. $\$ 2.00,1$ lb. $\$ 6.50$. Postpaid.

Ponderosa. The largest tomato and a great faOnderosa. vorite for the family garden. The fruit is deep purple, slightly ribbed, solid, and of luscious Havor. The fruit will often weigh over a pound, and most people think it the best kind for slicing. Pkt. 10 cts., oz. 60 cts., $1 / 4$ lb. $\$ 2.00,1$ lb. $\$ 6.50$. Postpaid.

\section{With Bright Red Skin} Tait's Thoroughbred First Early.

We believe this to be the earliest Tomato in cultivation and should be given a trial by all growers. The vine is amazingly productive, and the scarlet fruit is quite smooth, of medium size and solid. Pkt. 20 cts., oz. 80 cts., $1 / 4$ lb. $\$ 2.50,1$ Ib. $\$ 8.00$. Postpaid.

Wayahead. Next to our First Early we consider this the best extra early red sort. er, much resembling Earliana but with potato leaf foliage. Pkt. 10 cts., oz. 60 cts., 1/4 Ib. $\$ 1.75,1$ lb. $\$ 6.00$. Postpaid.

Harlian Our market gardener's strain is decidedEarliana. ly superior to most stocks of this wellknown variety and is extremely early. The fruit is bright scarlet, of medium size, very prolific. Pkt. 10 cts., oz. 25 cts., 1/4 lb. 75 cts., 1 lb. \$2.75. Postpaid.

Tait's Thoroughbred NO-EQUAL. As an all-purpose Tomato we believe this variety has No EQUAL. did tomato for market, the home garden and canning. The vines are healthy, very vigorous and productive, bearing fruit over a long season. The bright scarlet fruits are always smooth, solid and of delicious flavor. Pkt. 20 cts., oz. 80 cts., $1 / 4$ Ib. $\$ 2.50,1$ lb. $\$ 8.00$. Postpaid. See illustration front cover.

John Baer. An extremely early variety of much merit. The fruit is nearly round, of a pleasing scarlet color, good John Baer. quality and very productive. Pkt. 10 cts., oz. 40 cts., 1/4 Ib. \$1.25, 1 Ib. \$4.00. Postpaid. Bonney Best. Early, prolific and of good size, this tomato has become very popular on account of its many good is a beautiful red, and the fruit grows in clusters. Pkt. 10 cts., oz. 25 cts., 1/1 Ib. 75 cts., 1 Ib. $\$ 2.75$. Postpaid.

Chalk's Early Jewel. One of the best second early tomatoes. Vines are vigorous and very productive. The fruits Hipen early, are bright deep scarlet red, nearly round, smooth, of large size and the best qualíty. Pkt. 10 cts., oz. 25 cts., 1/1 Ib. 75 cts., 1 Ib. \$2.75. Postpaid.

Stone. Possibly the best all-round main crop red tomato and few sorts are as good as this for canning. The fruit is

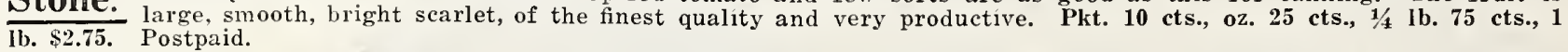

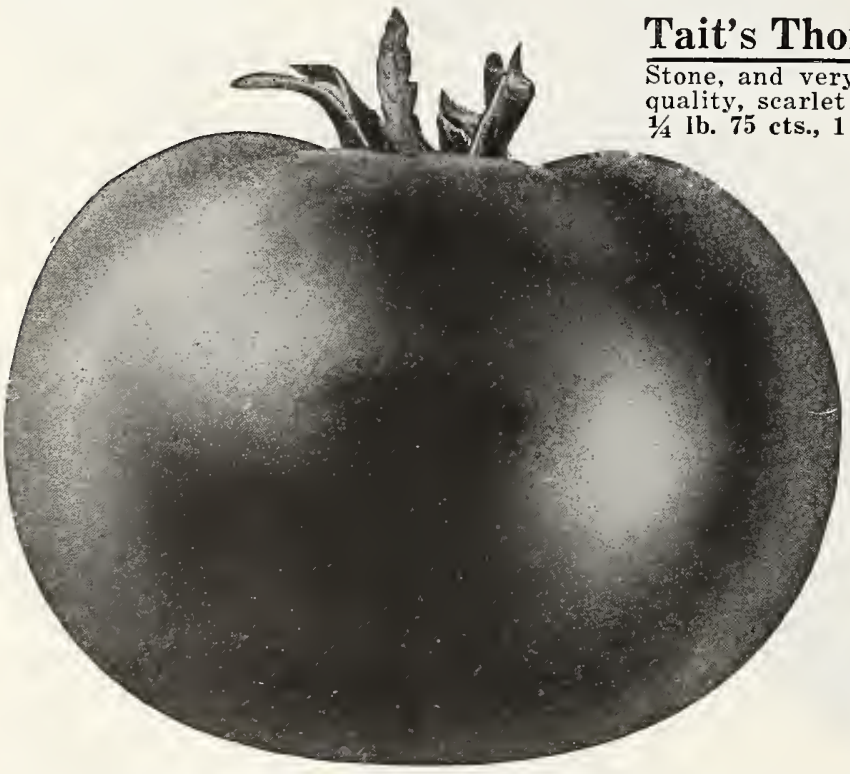

Another good main crop tomato that ripens with the Stone, and very much like it. The fruit is roundish, large, smooth, of fine quality, scarlet red, extremely solid and productive. Pkt. 10 cts., oz. 25 cts., 1/4 Ib. 75 cts., 1 Ib. $\$ 2.75$. Postpaid.

\section{With Yellow Skin}

Golden Queen. The handsomest yellow tomato and markable solidity of the flesh. The fruit is large, smooth, of good quality and very productive. Pkt. 10 cts., oz. 40 cts., $1 / 1 \mathrm{lb}$., $\$ 1.25,1 \mathrm{lb}$. $\$ 4.00$. Postpaid.

\section{Small Fruiting Tomatoes}

The Iruits of these are well flavored and largely used for making fancy pickles, preserves and salads.
Red Cherry
Red Pear
Red Plum
Yellow Cherry
Yellow Pear
Yellow PIum

Above six varieties: Pkt. 10 cts., 1/2 oz. 30 cts., oz. 50 cts.

Comet. Green house men all know the good qualities of this red forcing tomato, the productiveness of tonishing. It is very uniform in shape, perfectly smooth and of specially fine flavor. Pkt. 10 and 25 cts., oz. 75 cts. Postpaid.

Remember we deliver free at catalogue prices-except where noted. Write for special prices in large quantities, 


\section{TUR N IPS}

CULTURE.-1 ounce is sufficient for 100 feet of drill; $1 \frac{1}{2}$ to 2 pounds to an acre. The successful cultivation of turnips requires land which has been thoroughly enriched and put in the best condition. For spring use, sow the earlier varieties about the last of February, $3 / 4$ inch deep in drills 18 inches apart, and thin the plants to 6 inches apart. For fall and winter supply sow from the middle of July to the first of September, though the strap leaf varieties will usually make turnips if sown as late as the middle of September. For the rutabagas and large turnips the drills ought to be two feet apart, and the plants thinned to ten inches. If desired, they may be also sowed broadcast.

\section{WITH WHITE FLESH}

White Milan. This extra early turnip is a selection from the Mhite Milan. well-known Purpie Top Milan, and is particularly recommended to all market gardeners. Pkt. 5 cts., oz. 10 cts., $1 / 1$ lb. 30 cts., 1 lb. $\$ 1.00$. Postpaid.

Purple Top Milan. For many years this hardy flat variety was more profitabie than any other exSnowball. Pkt. 5 cts., oz. 10 cts., $1 / \mathbf{4}$ lb. 30 cts., 1 lb. $\$ 1.00$. Postpaid.

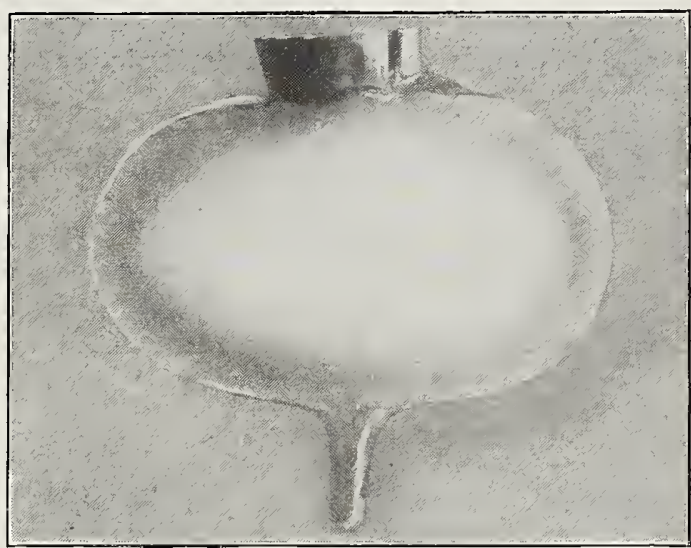

Extra Early White Milan Turnip.

Snowball. A very early globe-shaped variety, beatifully white and most delicate in flavor, being really sweet so long Snowball. as it is growing. We recommend it for sowing to immediately follow the White Milan, these two representing the best to be had in spring tumips. Pkt. 5 cts., oz. 10 cts., 1/4 lb. 25 cts., 1 lb. 75 ets. Postpaid. Large White Norfolk. A splendid turnip, which has long been a standard sort for stock feeding, and is used to a proper cultivation attains a very large size. The flesh is sweet, but somewhat coarse of grain at maturity. In the vicinity of Norfolk, the leaves are largely used for "greens," sowings being made through September, October and November. Pkt. 5 cts., oz. 10 cts., $1 / 4$ lb. 25 cts., 1 lb. 75 cts. Postpaid.

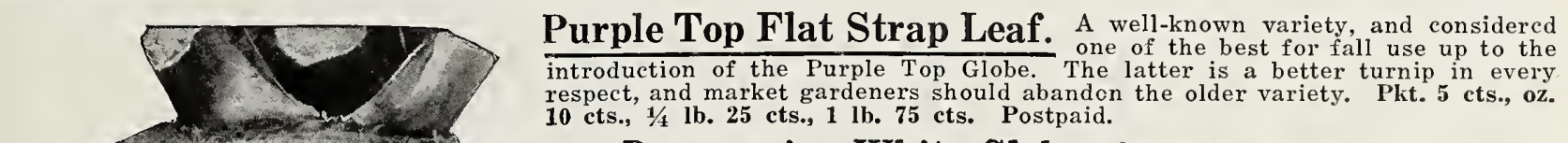
10 cts., 1/4 lb. 25 cts., 1 lb. 75 cts. Postpaid.

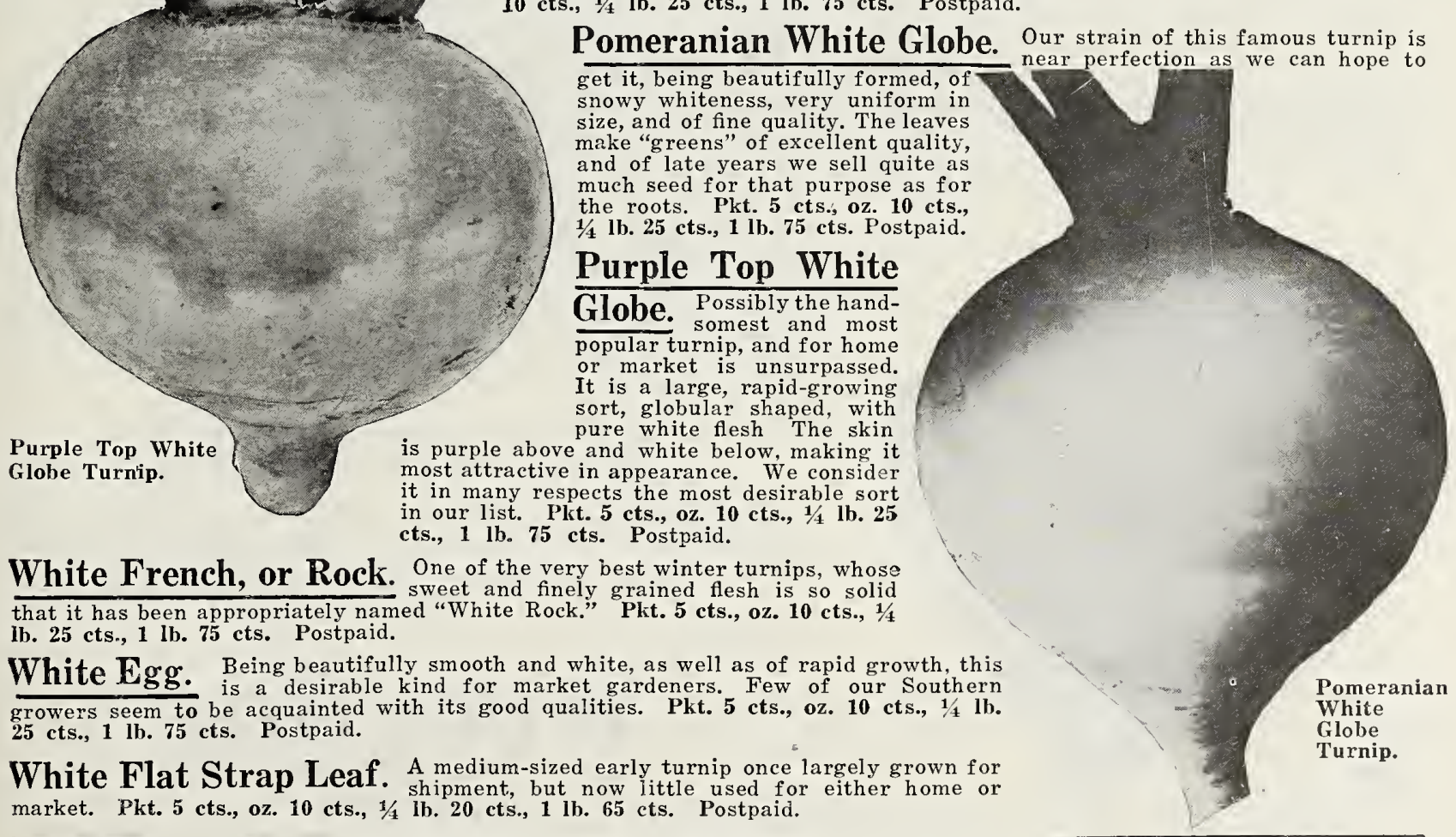

Remember we deliver free at catalogue prices-except where noted. Write for special prices in large quantiśss. 


\section{WHITE FLESH---Continued}

Cow Horn. The long, white root of this variety grows half above the ground, and is usually so crooked as to be unthe winter. Pk. sightly. The quality, however, is all that could be wished, and it is one of the best turnips for keeping in oz. 10 cts., 1/1 lb. 25 cts., 1 lb. 75 cts. Postpaid. Southern Prize, or Dixie. \begin{tabular}{l} 
Hardy and needs no protection, principally grown for winter and spring salad. Pkt. \\
\hline
\end{tabular}

Seven Top. The leaves of the Seven Top Turnip are very abundant, and were formerly considered the best for Pkt. 5 cts., oz. 10 cts., 1/4 lb. 30 cts., 1 lb. $\$ 1.00$. Postpaid.
Pre and White Norfolk are really better kinds for this purpose.

\section{WITH YELLOW FLESH}

Amber Globe. A very superior turnip, which keeps well, and As a general favorite throughout the South. Pkt. 5 cts., oz. 10 cts., $1 / 1$ lb. 25 cts., 1 lb. 75 cts. Postpaid.

Yellow Aberdeen. We had much difficulty inducing Southits good qualities gradually became known. No kind equals it in keeping under unfavorable conditions, and is particularly recommended for stock feeding during the winter, although good for table. It is of slow growth, and should not be sown later than August. Pkt. 5 cts., oz. 10 ets., $1 / 1$ lb. 25 cts., 1 lb. 75 cts. Postpaid.

Golden Bail. This turnip of globe form and orange-colored flesh, while not large, is very solid, of splendid flavor, and keeps well. Pkt. 5 cts., oz. 10 cts., 1/1 1 b. 25 cts., 1 lb. 75 ets. Postpaid.

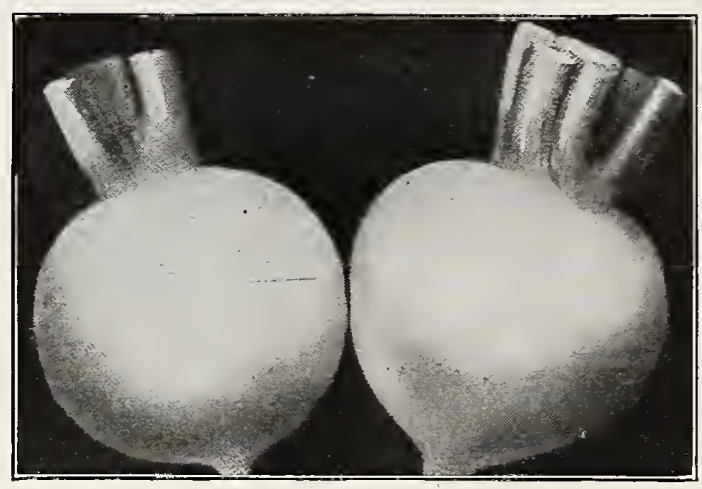

Golden Ball Turnip

\section{R UTA B A G A S}

\section{WITH YELLOW FLESH}

Tait's Thoroughbred Purple Top. Our Rutabagas are so unlike most of the cheap imported stocks which are when introduced in market. Where most have comsightly and wasteful necks, ours are beautifully symmetrical, splendid for market, and the yield per acre is enormous. Southern farmers make a great mistake in not growing more rutabagas, the value of which for stockmen can hardly be overestimated. Pkt. 5 cts., oz. 10 cts., $1 / 11$ lb. 25 cts., 1 lb. 75 cts. Postpaid.

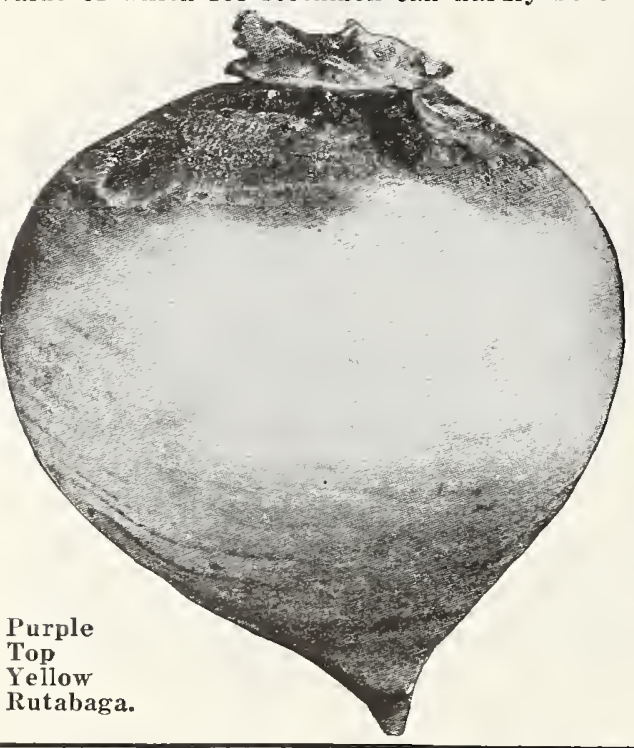

True Globe Shaped. "Entirely devoid of the objectionable fine grained, and perfect in both color and contour, this is literally the ideal rutabaga. For market gardening such a symmetrical, handsome root means fancy prices, or else ready sale when less highbred stocks are not wanted at any price, and all those who cater to the family trade should use it exclusively. Pkt. 5 cts., oz. 10 cts., $1 / 1$ lb. 30 cts., 1 lb. 90 cts. Postpaid.

\section{WITH WHITE FLESH}

Breadstone. A great improvement upon the ordinary white Breadstore rutabaga, being fine grained, of the most delicate havor, and very early. The root is oval shaped, smooth, and almost without neck. It is becoming a favorite variety everywhere. Pkt. 5 cts., oz. 10 cts., $1 / 1 / 1$ lb. 25 cts., 1 lb. 75 cts. Postpaid.

Budlong. Identical with Breadstone, described above.

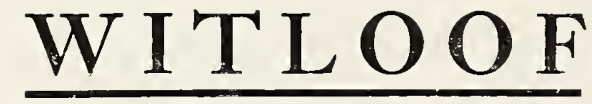

(See Chicory.)

Remember we deliver free at catalogue prices-except where noted. Write for special prices in large quantities. 


\section{HERBS FOR THE GARDEN}

Every garden should contain an assortment of herbs, the uses to which they may be put in the kitchen being innumerable. Their cultivation in general requires very little care, and many kinds, being perennial, need to be sown only once. No special soil is necessary, and the harvesting of the crop is exceedingly simple. The seed should be sown as early as possible in spring, the plants thinned to a proper distance, and an occasional hoeing done to prevent weeds and grasses from smothering them at first. The best time for harvesting is just at the time the flowers begin to appear, and the drying should be done as quickly as possible in a dark room. If kept in closeiy corked bottles, the quality of the leaves will be retained much better than if exposed to the air.

Market gardeners with small places near cities will generally find herbs one of the most profitable crops they can raise.

Anise. (Pimpinella Anisum.) A well-known annual herb, Anise. used principally for seasoning and garnishing. Pkt. 10 cts.; oz., 35 cts.

Balm. (Melissa Officinalis.) The leaves of this perenBalm. nial are fragrant, and are sometimes used for making a tea for cases of fever. Pkt. 10 cts., oz. 50 cts.

Caraway. (Carum Carui.) Grown for the seeds, which Caraway. are used in confectionery, pastries, etc., the leaves are also sometimes put in soups. Pkt. 10 cts., oz. 35 cts.

Catnip. (Nepeta Cataria.) The leaves of this perennial ats. It make used for seasoning, and it is also a tonic for cts., oz. 50 cts.

Coriander. (Coriandrum Sativum.) A hardy annual, the Coriander. seeds of which form an important article of commerce, being largely used in the manufacture of liquors, in confectionery and as a disguise to the taste of medicine. Pkt. 10 cts., oz. 35 cts.

Dill. (Anethum Graveolens.) An annual with seeds of Dill. a peculiar pungent taste. They are used in various ways as a condiment, and often added to pickled cucumbers to heighten the flavor. Pkt. 10 cts., oz. 35 cts.

Fennel. (Anethum Foeniculum.) An aromatic annual for used in flavoring in cooking ; also for making tea for children. Pkt. 10 cts., oz. 35 cts.

Horehound. (Marrabium Vulgare.) The leaves and for subduing irritating coughs. Pkt. 10 cts., oz. 50 cts.

Lavender. (Lavendula Vera.) A hardy perennial, proLavender. ducing long, sweet-scented spikes of flowers, which are used for the distillation of oil, lavender water, etc. The flowers are also dried before they fade and laid away among linens, to which they impart their characteristic and very charming odor. Pkt. 10 cts., oz. 50 cts.

\section{Mint Roots. (See Index.)}

Pot Marigold. (Calendula Officinalis.) Grown altofor soups. It is an annual with showy flowers. Pkt. 10 cts., oz. 35 cts.

Rosemary. (Rosemarinus Officinalis.) An ornamental perennial, very fragrant and with a bitter, Tungent navor. It also furnishes an oil for various purposes. The plant yields little until well established in the second season. Pkt. 10 cts., oz. 50 cts.

Sage. (Salvia Officinalis.) A hardy perennial, the leaves of Sage. which are plucked about the time the flower stalks are forming, then spread in a dark rocm and dried as quickly as possible. Pkt. 10 cts., oz. 50 cts.

Sweet Marjoram. (Origanum Marjoranna.) T h both when green and after drying. Pkt. 10 cts., oz. 35 cts.

Summer Savory. (Satureia Hortensis.) A useful culiers of which are put in dressings and soups. Hardy annual. Pkt. 10 cts., oz. 35 cts.

Sweet Basil. (Ocymum Basilicum.) An annual, producSweet Basil. ing seeds which have nearly the flavor of cloves. The seeds, stems and tops of shoots may be used for sauces and stews. Pkt. 10 cts., oz. 50 cts.

Thyme. (Thymus Vulgaris.) A favorite herb for season1hyme. ing, and supposed to possess various medicinal qualities. The plant is perennial, and both leaves and tops of stems are utilized. Pkt. 10 cts., oz. 50 cts.

\section{BIRD SEE D, ETC.}

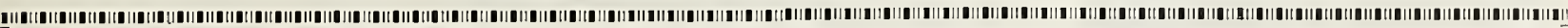

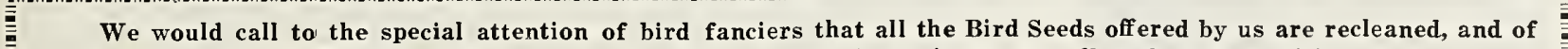
the highest quality. This should be borne in mind when comparing prices on small or large quantities.

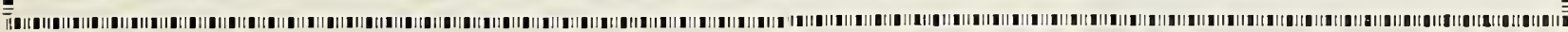

All prices are subject to change without notice. Write for prices on larger quantities.

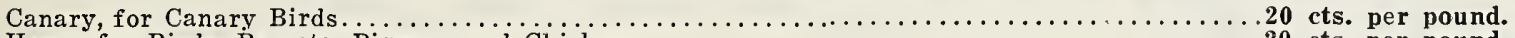

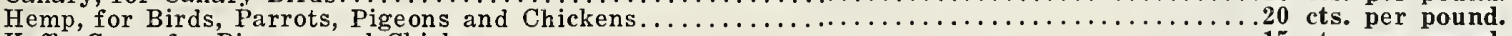

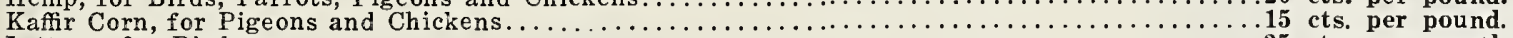

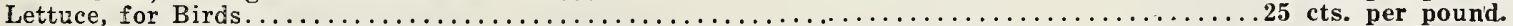

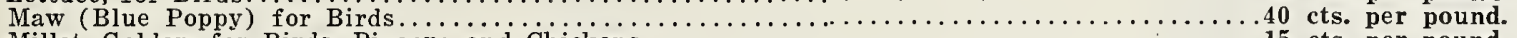

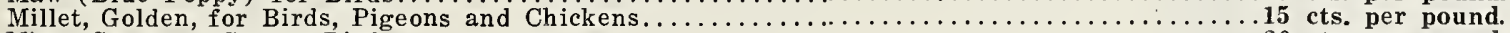

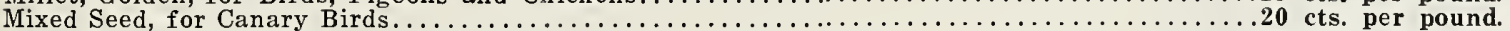

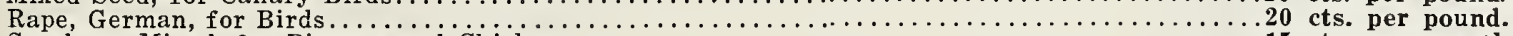

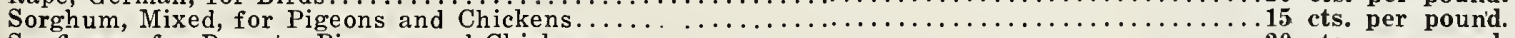

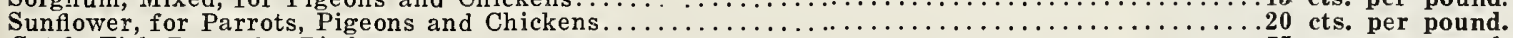

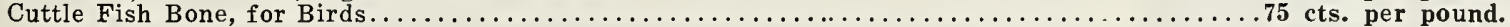

Postpaid Postpaid. Postpaid. Postpaid. Postpaid. Postpaid. Postpaid. Postpaid. Postpaid. Postpaid. Postpaid.

The words Thoroughbred Seeds being a registered trade-mark (U. S. Patent Office, No. 51052), and the word Thoroughbred being also a registered trade-mark (U. S. Patent Office, No. 92011), all persons are warned against their use in connection with the advertising or sale of seeds. We solicit the help of our friends in the detection and punishment of infringements of our copyright.

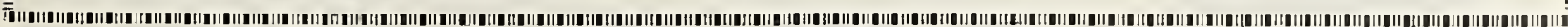

Remember we deliver free at catalogue prices-except where noted. Write for special prices ln large quantities. 


\section{WHITE FIELD CORNS}

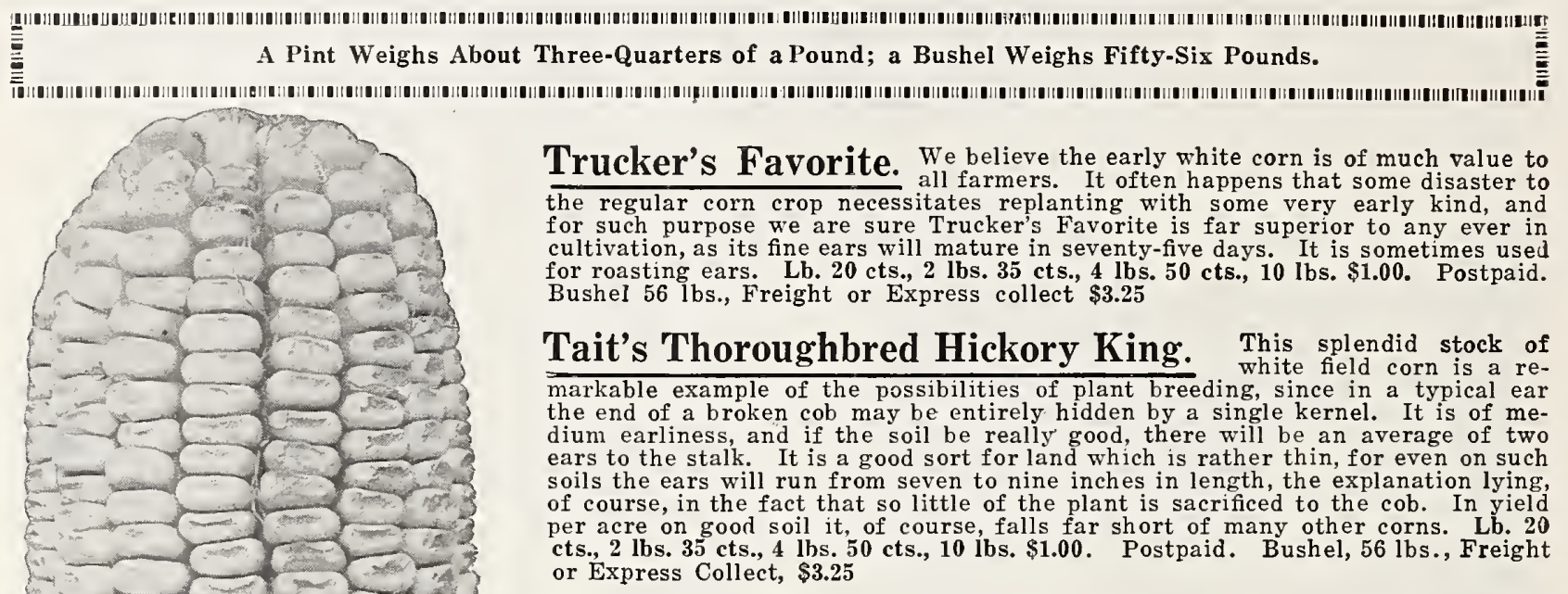

\section{Tait's Thoroughbred Virginia Mammoth. This remarkably} tion, bred up from the well-known Horsetooth, always finds a more ready sale than any field corn on our list, and never disappoints the farmer who puts it on good soil. We know of no corn which can show so handsome a grain, and it is very satisfactory as to productiveness. In earliness it does not compare with the early yellow varieties, but where this is not an important point it may be unreservedly commended as the most perfect white corn in existence for the tidewater section of Virginia and North Carolina. Lb. 20 cts., 2 lbs. 35 cts., 4 lbs. 50 cts., 10 lbs. $\$ 1.00$. Postpaid. Bushel, 56 lbs., Freight or Express Collect, $\$ 3.25$

\section{Virginia Horsetooth. There can be no question of the usefulness of this famous corn on any land in high cultivation.} We do not recommend it for thin soils, but under suitable conditions it will give a splendid yield. The ears, which are often twelve inches long, average fourteen rows, the grain being of extra length. Lb. 15 cts., 2 lbs. 25 cts., 4 lbs. 45 cts., 10 lbs. 90 cts. Postpaid. Bushel, 56 lbs., Freight or Express Collect, \$2.75.

Boone County Mammoth. One of the best white field corns for gencorn shows for perfect ears and enormous yields, the rows running from eighteen to twenty-four, and the cob is rather large; but the grain is deep, and the ears generally filled quite over the tips. On rich soil, both stalk and foliage make a strong, heavy growth, making it very desirable for ensilage. Lb. 15 cts., 2 lbs. 25 cts., 4 lbs. 45 cts., 10 lbs. 90 cts. Postpaid. Bushel, 56 lbs., Freight or Express Collect, \$2.75.

\section{Tait's Thoroughbred Prolific. Now that prolific corns have become} so popular, we take pleasure in offering this new sort. On land of good fertility it may be relied upon to produce from three to five ears to the stalk, although in our trials we have seen as many as six well developed ears on a single stalk. The cob and ear are of medium size and will mature in less than a hundred days. Every one interested in prolific corn should plant a portion of their crop in this variety. Lb. 20 cts., 2 lbs. 35 cts., 4 lbs. 50 cts., 10 lbs. $\$ 1.00$. Postpaid. Bushel, 56 lbs., Freight or Express Collect, $\$ 3.25$

Bigg's Seven Ear. Another prolific corn much liked in many sections of able than Tait's Thoroughbred Prolific. Lb. 15 cts., 2 lbs. 25 cts., 4 lbs. 45 cts., 10 lbs. 90 cts. Postpaid. Bushel, 56 lbs., Freight or Express Collect, \$2.75.

Tait's Virginia Mammoth Corn.

Remember we deliver free at catalogue prices-except where noted. Write for special prices in large quantities. 
GEO. TAIT \& SONS, INC., NORFOLI, VA.

\section{YELLOW FIELD CORNS}

Tait's Thoroughbred Mortgage Lifter. For some time we have been anxious to introduce an early yellow corn with a small cob that would produce two ears to the stalk, and we believe in our' improved "Mortgage Lifter" we offer a corn that is nearly ideal. The ear is of good size. The cob is red and small. The grain is fairly deep and the right shape. The color is a beautiful deep yellow. The stalk is of medium size and makes sufficient fodder, and will mature a crop in less than a hundred days. It has been bred to produce two ears and more of the stalks will bear two ears than any other yellow variety of which we know. Lb. 25 cts., 2 lbs. 45 cts., 4 lbs. 60 cts., 10 lbs. $\$ 1.20$. Postpaid. Bushel, 56 lbs., Freight or Express Collect, $\$ 3.75$

Tait's Thoroughbred Golden Wedge. The best yellow variety for The rrain of this bright yellow corn approaches the ideal nearly than any other variety of corn that we have ever seen, and we find that the same impression has been made upon all the farmers who have seen it on the ear. The grain, being a real wedge-very long and tapering-is packed around the medium-sized cob in such a way as to secure the maximum amount of grain to the ear, while in weight and attractiveness of color it holds its own with any of the standard field varieties. A good kind for planting after the potato crop has been harvested, as it matures in about 90 days. Lb. 20 cts., 2 Ibs. 35 cts., 4 Ibs. 60 cts., 10 lbs. $\$ 1.20$. Postpaid. Bushel, 56 lbs., Freight or Express Collect, $\$ 3.75$.

Improved Golden Dent A well-known early yellow field corn that will Improved Golden Dent. usually mature in ninety days. It is a hardy, healthy, vigorous growing variety, good for either hard corn or ensilage, and splendid for a late crop. Lb. 20 cts., 2 lbs. 30 cts., 4 lbs. 50 cts., 10 lbs. $\$ 1.00$. Postpaid. Bushel, 56 lbs., Freight or Express Collect, $\$ 2.90$.

Mastodon Dent. The originator, who is one of the most experienced corll Mrowers in the United States, regards this as one of the finest of all yellow corn. Although the ear is of extra large size, it is no less remarkable for its earliness. The cob is large, like that of Boone County, and for this reason does not do so well in the tidewater section of Virginia and North Carolina. Lb. 20 cts., 2 lbs. 30 cts., 4 lbs. 55 cts., 10 Ibs. \$1.00. Postpaid. Bushel, 56 Ibs., Freight or Express Collect, $\$ 2.90$.

White Cap Yellow Dent. The small, short stalk and scanty leafing of this Wartive little promise of the really handsome ear, which appears in due time. It is much liked by those who do not care to use the fodder, being very early as well as productive. The kernels are bright amber yellow at the tip and white on the outer end, making it very distinct in appearance. Lb. 20 cts., 2 lbs. 30 cts., 4 lbs., 55 cts., 10 lbs. $\$ 1.00$. Postpaid. Bushel, 56 lbs., Freight or Express Collect, $\$ \mathbf{2 . 9 0}$.

Bloody Butcher. The color of this famous corn is an odd mixture of yellow and red, the spattered effect being such as to suggest the rather startling name of "Bloody Butcher." The ear is extraordinarily long and thick, the kernel of good shape, and in every essential respect, including earliness, it ranks very high indeed. Lb. 20 cts., 2 lbs. 30 cts., 4 lbs. 50 cts., 10 lbs. $\$ 1.00$. Postpaid. Bushel, 56 lbs., Freight or Express Collect, \$2.90.

If you have not been getting proper results from the seed
corn that you have been planting, let us assist you with our
THOROUGHBRED STRAINS

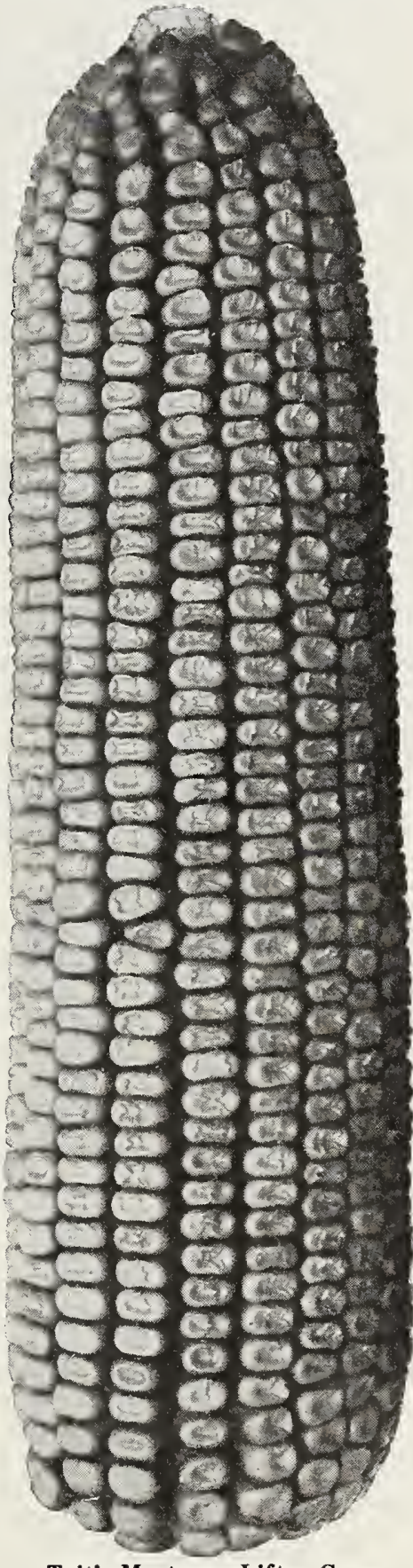

Tait's Mortgage Lifter Corn.

Remember we deliver free at catalogue prices-except where noted. Write for special prices in large quantities. 


\section{GR A I N}

\section{STANDARD VARIETIES USEFUL IN THE SOUTH}

\section{PRICES F. O. B. NORFOLK, AND ARE SUBJECT TO CHANGE WITHOUT NOTICE}

\section{B A R L E Y}

Forty-eight pounds to the bushel. For an acre, two bushels. Beardless. The great value of Barley for winter pasas yet but many Southern dairymen have adopted it as one of their main crops for this purpose, using it also for hay. If the ground is reasonably strong, it may be firmly established before winter, and will bear almost continuous grazing until late spring, the beneficial effect upon milch cows in particular being most noticeable. If intended to be cured for hay, the head should not be allowed to form. Sowings are made both in summer and fall, and sometimes it is broadcasted when corn or cotton crops are "laid by." Price per bushel on application.

\section{BUCK W HE AT}

Forth-eight pounds to the bushel. For an acre, one bushel.

Buckwheat thrives where few other plants will. In excessively hot weather buckwheat is liable to blight, and the seeds should not be sown in the latitude of Norfolk before the middle of July. It may be sown either in drills or broadcast.

Japanese. A distinct variety, earlier the Silver Hull. The plant is large and vigorous, and the flour made from it is of the best quality. Price per bushel on application.

\section{OATS}

Thirty-two pounds to the bushel. For an acre, two bushels.

Burt, or Ninety-Day. $\begin{gathered}\text { Probably } \\ \text { the best }\end{gathered}$ spring oat for general use in the South, and now very largely grown in Virginia and the Carolinas for both hay and grain. Planted in February, March and April, they can usually be relied upon to mature in time to avoid all injury from heat, and the grain is free from rust. Price per bushel on application.

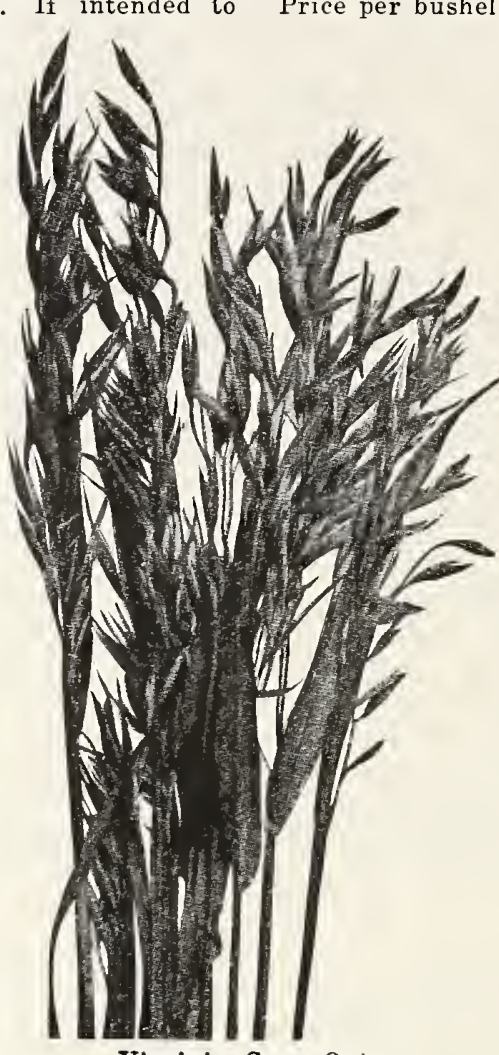

Virginia Gray Oats.
Virginia Gray, or Winter Turf Oats.

A general favorite in the South for fall planting, and much used for winter pasturage as well as for the grain. It is a hardy variety of very vigorous growth and stools finely, making a better turf than any other kind. Sown in September of October, they will be well set before cold weather, and may be grazed freely throughout the winter. Spring sowings in March will give very good results, and our customers will find them far more productive than the ordinary spring oat. Price per bushel on application.

\section{R Y E}

Fifty-six pounds to the bushel. For an acre, one and one-half bushels.

For winter pasturage few crops compare with Winter Rye, its adaptability to almost all soils and situations being enough to make it a universal favorite. Inexpensive, very productive and of remarkable nutritive value, it can be used to advantage on every farm where stock is kept, and we strongly recommend that all unused land be covered with rye during the winter as a protection. It also ranks among the best green manures, and is very largely used for that purpose.

Abruzzi. This variety of winter rye Abruzzi. is becoming more popular each year. It is ready for grazing about ten days earlier than any other sort, and will produce nearly as much grain. Price per bushel on application.

Rosen. A splendid variety that proRosen. duces a strong, vigorous straw, and stools to a remarkable degree. It is destined to take first place as a leading variety of Winter Rye. Price per bushel on application.

\section{WHEAT}

Fulgham. A splendid variety of the rust proof type. It is earlier than either the Appler or Bancroft and a heavier yielder. One of the best varieties for spring planting. Frice per bushel on application.

Red Rust Proof. No deseription is needed of this stanversally used throughout the South. Price per bushel on application.

Appler. This is a Southern-grown type of the Red Rust Appler. Proof Oat, and is unquestionably one of the most valuable the Southern farmer can grow, especially if a crop of grain is desired. Appler cannot be considered an early sort, and for that reason should be sown in the fall. Price per bushel on application.
Sixty pounds to the bushel. For an acre, one and one-half bushels.

Leap's Prolific. This Virginia-bred selection of beardcap's Prolific. less wheat has now established a wids reputation for productiveness and high milling value. We have more demand for it than for all other beardless kinds combined. Price per bushel on application.

Fulcaster. This variety is favored by many planters of North and South Carolina. It is a vigorous grower and makes the finest quality of flour. Price per bushel on application. 


\section{SOR GHUM}

Prices are cash, F. O. B. Norfolk, and subject to change without notice.

CULTURE-When sown for hay, Sorghum is usually sown broadcast at.the rate of 2 bushels per acre, but it will be found more satisfactory if it is put in with wheat drill. When sown thickly, the stalks do not have a chance to get too large, which insures a maximum yield with the least waste. Sorghum is of rapid growth and often is ready for feeding in 60 days after sowing; and on good soil it will produce from 3 to 5 tons of cured hay per acre. It is also very slow in curing, and shouid be left out for 10 days after cutting if the weather is fine, or twice that length of time if there is much rain. It suffers very little injury from such exposure, and has been known to make good hay after remaining wet for a long time. Opinions vary as to the best time for catting, but it is best done when there are signs of ripening, as it then cures better than when green. After drying in windrows for 2 or 3 days it may be put in the barn. When grown for summer feeding it should be grown in drills $2 \frac{1}{2}$ to 3 feet apart, with about 8 stalks to the foot, or in drills 2 feet apart, with a dozen or more stalks to each hill. 12 pounds per acre are sufficient for this method. 5 pounds per acre when grown for syrup. Sow from the middle of April to the first of August.

Early Orange. This has been variety for stock feeding, since it produces the strongest stalks, and is less liable to lodge than any of the other saccharine sorghums. Lb. 20 cts., Postpaid. Write for prices on larger quantities.

Sugar Drip. This sorghum is said

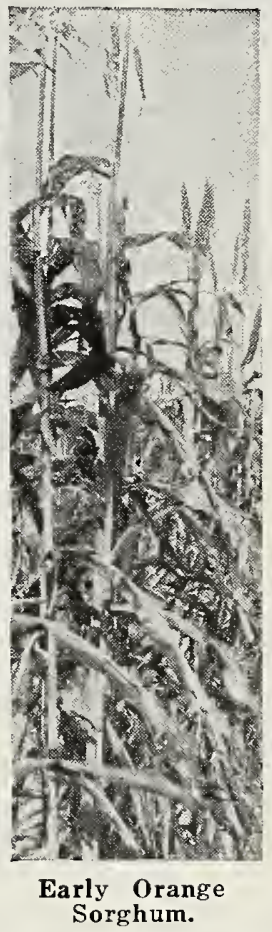
of syrup than either Amber or Orange, and of a decidedly better quality. Since the making of syrup is not so difficult, this should encourage its making not only for the home, but for local markets as well. For forage it is the equal of either of the other varieties, but not quite so early as the Orange. Lb. 20 cts. Postpaid. Write for prices on larger quantities.

Early Amber. An early productive variety, which grows

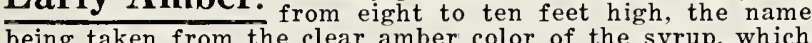
is of the best quality. As a forage plant it is very valuable, and affords on rich soil two or three cuttings during the summer. Sow in drills two feet apart and cultivate as corn. For an acre, ten pounds in drills, or five pounds if sown for syrup; two bushels sown broadcast for hay. Lb. 20 cts. Postpaid. Write for prices on larger quantities.

Rural Branching, or Millo Maize. This so rwhich is non-saccharine, flourishes in the hottest weather', growing in a bush-like form and throwing out suckers from all the lower joints. The foliage procured is of fair quality and may be cut at any stage for green feed or cured for fodder. Make the drills four feet apart, sow the seed thinly and cultivate as corn. For an acre, five pounds. Lb. 20 cts. Postpaid. Write for prices on larger quantities.
White Kaffir Corn. This sorghum, wich is a low, perfectly erect, and quite distinct from the other nonsaccharine varieties, branching from the top joints instead of stooling from the roots. It may be cured, thel stalks as well as blades, into excellent fodder, but if wanted for this purpose should be cut as the first seed-heads come into bloom; if sown as soon as the ground is warm a second crop may be made afterwards. It is available for green feed from early in the season to winter, and is greatly relished by all kinds of stock, its nutritive value ranking very high indeed. The grain is produced on heads about one foot long, and may be fed to poultry or ground into a flour very useful for stock feed. Sow in rows three feet apart and cultivate as corn, or broadcast for forage, either alone or with cowpeas. For an acre, five pounds in drills, or fifty pounds broadcast. Lb. 20 cts. Postpaid. Write for prices on larger quantities.

\section{SUDAN GRASS}

Introduced from Africa a few years ago, this species of sorghum has become quite popular in the Southwest, where conditions are unfavorable for sowing other grasses successfully. The plant closely resembles Johnson Grass, except that it does not have the rootstalks by which the grass spreads from year to year, and being an annual, could never become the pest that Johnson Grass is. It grows from four to seven feet high, stools remarkably, and can be cut at least three times during a season. It is finer in growth than sorghum, and will produce more and better hay than millet. Being a warm-weather plant, in the latitude of Norfolk it should not be sown before May, or later than July. It is easily mowed, and cures readily. When sowed in drills eighteen inches apart four to six pounds are required to an acre, or about twenty-five when sown broadcast. As it is extremely difficult to tell the seed from that of Johnson Grass, only seed that has been tested for purity and germination should be sown. The seed offered by us has been thus tested. Lb. 20 cts. Postpaid. Write for prices on larger quantities.

\section{TOB ACCO}

CULTURE-1 ounce of tobacco produces at least 10,000 plants if sown properly. It is advisable to sow as early as possible, the usual custom being to make a large fire over the place intended for the seed-bed, in order to destroy weed seeds. The ground is put in the finest possible condition, the seed sown broadcast on the surface and pressed down firmly with a plank or the back of a spade, after which the bed must be protected by cottons or covering. When seedlings get 5 or 6 inches high, they are transplanted in rows 4 feet apart, with 3 feet between the plants. Cultivate thoroughly.

Improved Yellow Oronoko. A variety of much careful selection from Old Standard Yellow Oronoko, used for high-grade filler. Its growth is large, but erect, and its leaves while large, are of the finest texture. Pkt. 10 cts., oz. 40 cts., $1 / 4$ lb. $\$ 1.25$., lb. $\$ 4.50$. Postpaid.

Warne. A splendid variety for bright yellow wrappers. The leaf is of good size and very fine-grained. It is well. silky and is one of the best varieties when properly grown, and is a very popular sort. Pkt. $10 \mathrm{cts}$., oz. $40 \mathrm{cts} ., 1 / 4 \mathrm{lb}$. $\$ 1.25$, lb. \$4.50. Postpaid

Improved Long-Leaf Gooch. In this variety we bacco for Eastern North Carolina and South Carolina, and a portion of Georgia. It is adapted to sandy soils, grows unusually large, producing a large, broad leaf of No. 1 quality, cures well, and makes more pounds to the acre than most varieties. Pkt. 10 cts., oz. $40 \mathrm{cts} ., 1 / 4 \mathrm{lb}$. $\$ 1.25, \mathrm{lb} . \$ 4.50$. Postpaid.

Connecticut Seed Leaf. One of the hardiest varielent for cigar wrappers. It is best for sections were the tenderer and finer kinds do not succeed. Pkt. 10 cts., oz. 40 cts., $1 / 4$ lb. $\$ 1.25$, lb. $\$ 4.50$. Postpaid. 


\section{MISCELLANEOUS FIELD SEEDS BEANS, SOJA or SOY}

\section{(Soja Hispida.)}

Tests of the nutritive value of Soja Beans demonstrate that they are decidedly superior to cowpeas for feeding purposes, and we do not wonder that the demand each year is increasing enormously. It is now recognized as one of the most important forage crops for the South, as well as a nitrogen gatherer of the greatest value. The plant thrives in hot, dry weather, and does equally well on heavy and light soils. Sow either broadcast or in drills from May to July. Sow broadcast 1 to $1 \frac{1 / 2}{2}$ bushels to the acre of the large seeded varieties and $1 / 2$ bushel to 3 pecks of the small seeded varieties. In drills sow about 1 peck of the large varieties and about $1 / 2$ peck MULFORDCULTURE of the small varieties.

Biloxo. A late upright variety and in the South where the season Blloxo. is long it will be found a very good sort for hay and is also a very heavy yielder of beans. Seed brown, medium size. Write for prices.

Black Eyebrow. A variety that will be found especially adapted are sown for hog pasture where seasons are short, or where the beans inay be sown in April, and by July the pods will be filled ready to turn the hogs on. Seed brown with a black border. Write for prices.

Habalandt. A valuable all-purpose Soja Bean. It is early, proIabaland. duces a splendid quality of forage, and a heavy yield of seed. Seed yellow. Write for prices.

Laredo. One of the newer varieties, medium early and particularly Mammoth Yellow. The most popular of Soja Beans for forage larese purposes. It is a late variety, but produces

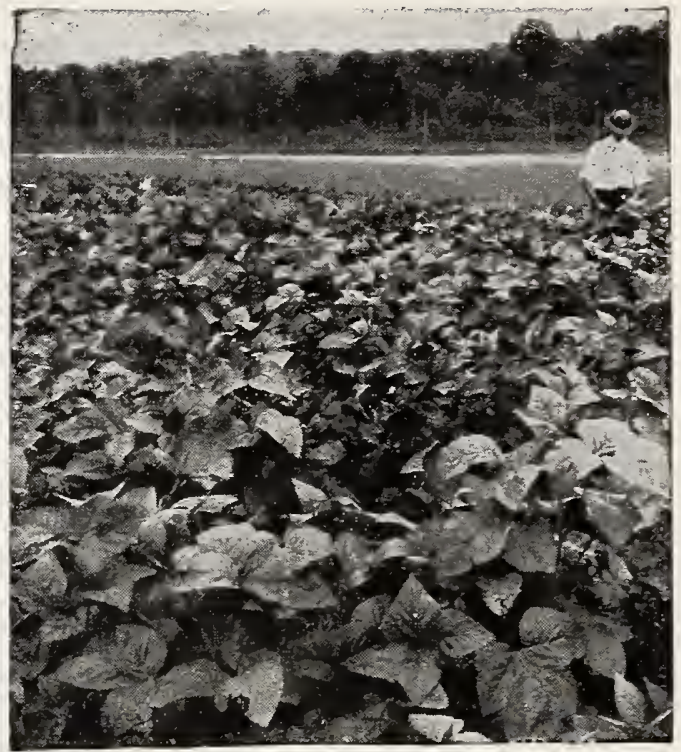

Mammoth Yellow Soy Beans Write for prices.

O-too-tan. Another good variety maturing later than Laredo. Well liked in the South. Yields a fine crop of hay. -too-tan. Seed black, small and round. Write for prices.

Wilson. A black-seeded variety, and one of the earliest and most prolific Soja Beans. A gocd sort to plant for hay, as it Wison. has a small stem, which enables it to cure easily. One of the best varieties for sowing in the North. Write for

Virginia. Quite similar in growth to Wilson. Excellent for forage, and becoming more popular each year. Seed small Irginia. and brown. Write for prices.

\section{BEANS, VELVET (Dolichos Multifiorus.)}

Among the newer forage plants this stands very high, as it is probably the most productive of its class and the best adapted to really poor soils. The growth is little less than marvelous, the vines attaining a length of ten or more yards, while the pods are borne in enormous clusters. All the experiment stations unite in declaring its nutritive value to be remarkable. For an acre, three pecks. Write for prices.

100-Day Speckled. A very rapid growing bean; making possibly more growth than any other pea or bean known. While it seldom matures in 100 days, it is very early, producing purple flowers in clusters. Tlie ong, containing speckled beans that are nearly round. Especially recommended for improving the soil. Can be sown broadeast, but we think it best to plant in drills and cultivate them once. After they get started they soon cover the ground with vines so dense that it is difficult to plow them under. We recoinmend turning stock on them, and let them eat and trample down the vines, which can then be turned under or left until spring. Should be planted in May or June, 1 or 2 pecks to the acre in drills, or one bush el broadcast. Write for prices.

\section{BEANS, WHITE or NAVY}

If saved bright, these are usually a most profitable crop, and there is no reason why more should not be grown in the South. Being perfectly dwarf and very prolific, an enormous quantity can be produced on an acre, and there is little cost of cultivation. As the weevil is likely to attack beans harvested during warm weather, it is best not to plant before the last of June. The ground should be well prepared by plowing and harrowing and dirils made about two and a half feet apart, the beans either drilled or dropped by hand, being covered a little less than two inches. Deep cultivation is undesirable, and it is only necessary to keep the surface well loosened. When the majority of the pods have turned yellow the plants should be pulled by the roots and, after being left for a day or two to dry, spread in the barn until thoroughly cured. In Carolina they are often very profitably used for replanting missing hills in the cotton fields. For an acre, three pecks. Lb. 25 cts. Postpaid. Write for prices on larger quantities.

BEETS, STOCK or MANGELS-(See Index)

\section{BROOM CORN}

Evergreen. This variety grows about eight feet high, has a permanent green color, and is practically free from crooked, irregular brush. It succeeds best on strong, deep soil with good drainage, and as cold is very injurious, sowings must not be made until the ground is warm. To keep the brush in good shape it is necessary to bend the head down about the time the seeds mature. Drill in rows three feet apart and cultivate as ordinary corn. For an acre, five pounds. Lb. 25 cts. Postpaid. Write for prices on larger quantities.

Remember we deliver free at catalogue prices-except where noted. Write for special prices in large quantities. 


\section{GEO. TAIT \& SONS, INC., NORFOLK, VA.}

\section{GHUFAS}

Spanish Chufas or Earth Almonds are a special nut grass largely grown in some sections for feeding to hogs, for which purpose they are highly recommended. After the crop is grown, hogs may be turned into the field, thus saving the labor of harvesting and feeding. Chufas do best on light, sandy soil, or rather soil that does not contain too much clay, except as a sub-soil. They should be planted in drills two and a half to three feet apart, dropping from three to five Chufas in a hill fifteen to twenty inches apart, cover about two inches, keep clean and stir the soil occasionally. Level culture is the best. They are very productive, nutritious and futtening. They can be planted in May, June or early in July. Pit. 15 cts., 1 lb. 50c. Postpaid. Write for prices on larger quantities.

\section{COT TON N}

Price of Cotton is eash, F. O. B., Norfolk, and subject to change without notice.

Planting cotton seeds without the least regard to the parent plant has becn only too common throughout the South, but we are glad to note now a much keener interest on the part of planters to avail themselves of every improvement in the quality of staple and productiveness. The various Southern experiment stations deserve much credit for the quality, and it would be difficult to exaggerate the value of their work in connection with cotton. Many fine selections have been bred in recent years, so that it is now possible to get varieties which will clean up over forty pounds of lint to each 100 pounds of seed cotton, and upwards of 300 bolls will often be found on a single plant. The old three-lock boll has given place to types which produce five locks, and there are scveral kinds which will average two bolls per joint. Out of the hundred more or less distinct varieties, we have endeavored to sclect those possessing the greatest number of desirable points, and we hope the list will interest many farmers now growing the old and very inferior stocks. If reasonable notice be given us, we will usually be able to supply any other kind desired. The long-stapled cottons are not recommended for sections north of South Carolina. Thirty pounds to bushcl.

CULTURE.-The cultivation of cotton varies considerably, of course, according to the locality and soil, but in general the ground should be prepared by thorough plowing and harrowing, with rows of 40 to 50 inches apart, 5 feet being given where the land is unusually rich. Seeding is best done with the cotton planter, and the young plants should be thinned to about 18 or 20 inches in the rows if the ground is very rich, 2 plants may be left in a hill, but otherwise only 1 . Frequently shallow cultivation is necessary to keep the surface free from crust, and planting should never be done until danger of frost is passed. For an acre, 1 to $1 \frac{1 / 2}{2}$ bushels.

Farly Prolific (Medium Boll)-This is a selection from the King's, as a large percentage of the flowers bear the Early Prolific. well-known red spot of the King's, but it is a full week earlier in maturing. The bolls are also larger, and it is a heavier and surer cropper. Pk. 90 cts., bu. $\$ 2.50$.

Early King. (Medium Boll)-This standard variety holds its own against the newer cottons, many of the best of which were bred from it, as evidenced by the King's characteristic red spot in the center of the bloom. It is Pk. 90 cts., bu. $\$ 2.50$.

Ideal. (Medium Boll)-Although several days later than Early King in maturing, this fine Georgia selection has been 1eal. making wonderful yields every year since its introduction, and competent judges believe it to be the best type of Prolific in cultivation. It is of rank growth and resists drought better than most kinds. Pk. 90 cts., bu. $\$ 2.50$. Big Boll Early. (Large Boll)-This is the best of the "big boll" varieties. It is early, the lint is of splendid quality,

\section{HIA $X$ (Jinum Usitatissimum.)}

Flax is very sensitive to cold and should not be sown until all danger of frost is past. When sown for the fibre, two bushels are usually sown to an acre. Write for prices.

\section{HI I $1 \mathrm{P}$ (Cannabis Sativa.)}

Grown for its fiber, from which many commodities are manufactured. For an acre broadcast one and a half bushels. Lb. 20c. Write for prices on larger quantities.

\section{P E A N U TS}

CULTURE.-Peanuts do well on most Southern farm land, whether light, loamy or even sandy, providing lime is not lacking; for without an abundant supply of lime they cannot be successfully grown, twelve to fifteen hundred pounds being often put upon an acre, with good results. Soils rich in marl, of course, require no liming. Plant in May or early June, the dwarf varieties in $2 \frac{1}{2}$ foot rows and the running varieties in 3 foot rows, dropping 1 nut 10 to 12 inches apart in the row, covering 1 to $1 \frac{1}{1 / 2}$ inches deep, and the peanuts should be shelled before planting. If large quantities are to be planted, a regular peanut planter should be used. When the vines are started, thorough cultivation must begin, and continue until just before the nuts begin to form. Do not cultivate too late in the season, as late cultivation is likely to injure the formation of the nuts. For an acre, from 1 to 2 bushels in the liull, according to size.

\section{W A R F} Mammoth Virginia Bush. This is by far the most profitable of dwarf varieties, as the nuts are almost as showy
as those of the Running Jumbo. Twenty-two pounds to the bushcl. Lb. 30 cts. Postpaid. Write for prices on larger quantities.

Spanish. Land which would not make 10 per cent of a crop of the Jumbo will oftcn produce excellent Spanish nuts, and they require very little cultivation. They are easily gathered, the nuts clinging firmly to the roots at haring or wholesome. Thirty pounds to the bushel. Lb. 30 ets. Postpaid. Write for prices on larger quantities.

\section{R U N N I G}

Running Jumbo. The largest variety and especially adapted to light, sandy soil. Twenty-two pounds to the bushel. Lb. 30 cts. Postpaid. Write for prices on larger quantities. 


\section{PEAS, CANADA FIELD}

These are very valuable for stock feeding, and are being more largely used each season. They are planted at the rate of two bushels to the acre broadcast, being usually sown with oats, a conbination which is extremely satisfactory. A bushel and a half of each to the acre is sufficient, the peas, of course, being plowed in to the usual depth and the oats put in afterwards with a harrow. Sowings may be made as early as February in ordinary years, and it is usually safe to put them in at any time up to the middle of March. They make a quick growth and produce an immense amount of the best forage at a time when feed is apt to be particularly scarce. When grown with oats they are very easily cured, and all kinds of stock are fond of hay, the nutritive value of which is remarkably high. Write for prices.

\section{RAPE, DWARF ESSEX}

An excellent forage plant, especially for sheep and hogs, and grown extensively for them in Europe though little known in this country until recent years. It grows with wonderful rapidity, being usually ready for pasturage six or eight weeks after sowing, and an acre is said to support a dozen sheep for more than a month, poultry also revelling in it. Almost any soil will grow it, and the yield per acre is simply enormous, more than twenty tons per acre having been often produced on good ground. Stock feeding upon Rape should be supplied with salt freely. When young it makes a delicious, tender, sweet salad, being often sown solely for this purpose. Sow from early summer until late fall, putting six pounds to the acre broadcast, or three pounds in drills. We offer the genuine Dwarf Essex, importing it ourselves, which is free from mixture with the inferior annual variety. Lb. 20 cts. Postpaid. By express or freight, 10 lbs., $\$ 1.25,25$ lbs. $\$ 2.50$.

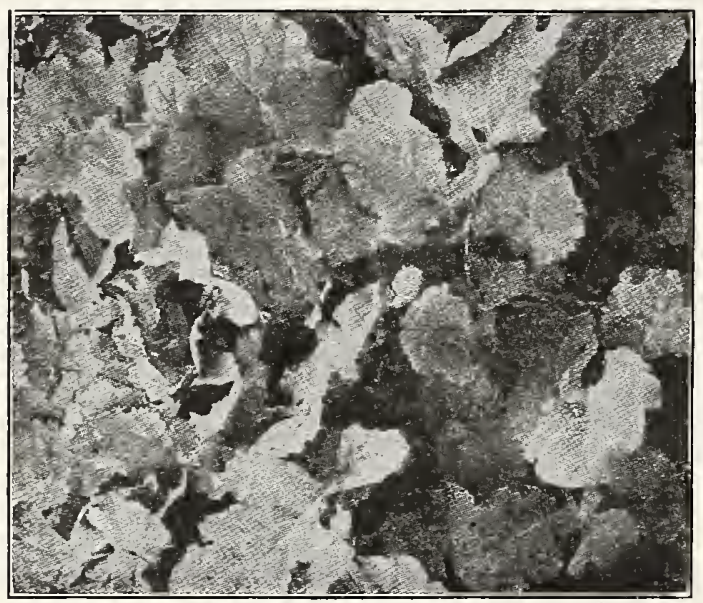

Dwarf Essex Rape.

\section{STOCK BEETS}

See Index.

\section{TEOSINTE}

(Reana Luxurians.)

A Central American fodder plant which is becoming more popular each year. It bears, in general appearance, considerable resemblance to Indian corn, but the leaves are longer and broader, while the stalk contains a sweet sap. The growth is exceedingly rapid, and it will often attain a height of twelve or more feet, an amazing number of shoots being produced by each plant, the stalks thickly set with succulent and nutritious foliage. Like most other plants of, its kind Teosinte is very sensitive to cold, and should, therefore, be grown only in warm climates, and sowing deferred until danger of frost is past. In favorable seasons several cuttings may usually be made. Make the rows three feet apart, dropping two or three seeds every twelve inches. We feel sure that all who need crops of this sort will be pleased with Teosinte having never yet received an unfavorable report regarding it. For an acre, four pounds. 1 oz. $10 \mathrm{cts}$, 1/4 lb. 20 cts., 1 lb, 65 cts. Postpaid. Write for prices on larger quantities.

\section{VETCH, HAIRY or WINTER}

\section{(Vicia Villosa.)}

After the most thorough tests, the best informed farmers now consider this one of the most valuable, if not most valuable of forage plants with in the reach of Southern farmers. Good authorities claim that it will yield from six to ten tons of green food to the acre, and its nutritive value has been determined to be much greater than clover. It makes good and easily cured hay, and is perfectly hardy, thriving on poor, arid, sandy soils, while on rich soil it makes a growth of five or more feet. Any kind of grain may be sown with it, to support the vines, but rye or oats will be found more satisfactory, and we think particularly good results will be obtained from twenty pounds of Vetch with one and a half bushels of Virginia Gray Oats, sown in September or early October. It is available for use a remarkably long time, as it is green through the winter and remains in condition until the middle of July, all stock eating it with the greatest relish. If desired, it may be cut very early in the spring, thus released for early plantings of other crops. For an acre sixty to seventy-

\section{SUNFLOWER, MAMMOTH RUSSIAN}

(Helianthus Annuus.)

This enormous variety is a great inprovement on the native sunflower, being much more vigorous and productive. It is adapted to almost any soil and situation, and there are few farms that could not spare some field for it which would otherwise lie unused, The flower heads frequently measure a foot and a half across, and are packed at maturity with large plump seeds marked with black and white. Poultry are extremely fond of the seed, and when thus fed fatten more rapidly. perhaps, than on any other food. In addition to the value of the seed, the leaves are used for forage and the stalks for fuel. Plant in drills three or four feet apart, with eighteen inches between the hills, and cultivate the same as corn. When the seeds are hard, cut off the heads and pile them loosely in a well-ventilated place to cure; they may then be easily threshed out and cleaned. For an acre, six pounds. Lb. 20 cts. Postpaid. Write for prices on larger quantities. 


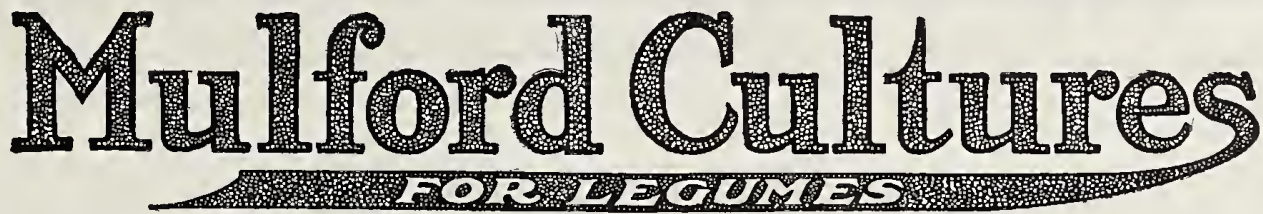

All the clovers, cowpeas, vetch, peas, beans, alfaifa, and many other leguminous plants, have the power to draw plenty of nitrogen from the air-if there are present what are called the nitrogen-gathering bacteria in the soil to attach themselves to the roots. These bacteria on the roots of this class of plants are necessary to enable the plants to do full work in nitrogen gathering. If they are not present the crop will be more or less a failure. Plenty of bacteria on the roots means rank growing crops, their absence means sickly-looking plants. Where successful crops of any of these plants mentioned have been grown before, there are bacteria in the soil for them, but on new ground or where these crops have not been grown, the bacteria must be supplied before success can come.

\section{LARGE RETURNS \\ EASY TO USE NO LABOR EXPENSE}

Mulford Cultures contain pure, tested strains of active, vigorous nitrogen-fixing bacteria, for inoculating seeds of legumes and improving the soil.

MULFORD CULTURES are prepared for: Alfalfa Vetch Soy Beans Crimson Clover Velvet Beans Garden Peas Sweet Clover Sweet Peas Garden Beans Red Clover Alsike Clover Lima Beans \begin{tabular}{l|l} 
Peanuts & Burr Clover \\
Cow Peas
\end{tabular} \mid Lespedeza

NOTE.-Always specify on your order what crop you want to inoculate, as there is a different strain of bacteria for each legume.

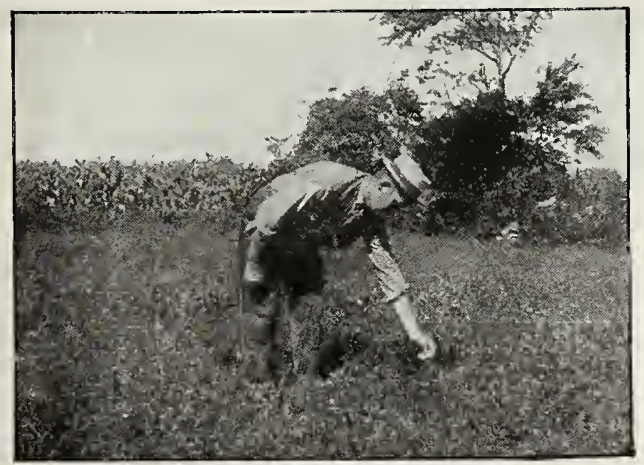

Alfalfa Without Inoculation.

\section{FREE DESCRIPTIVE FOLDER SENT UPON REQUEST}

\section{Small Seeded Legumes}

(Alfalfa and all varieties of Clover)

10 bu. size....\$8.00

$21 / 2$ bu. size.... 2.25

1 bu. size.... 1.00

\section{Large Seeded Legumes}

(Soy Beans, Cow Peas, Vetch,

Garden Peas and Beans)

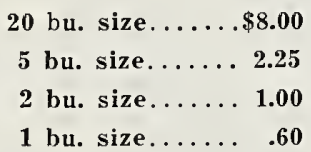

Garden size (for (Garden Beans, Garden Peas, Lima

Beans and Sweet Peas) ....................35

NOTE-A l w a y s specify what crop you want to inoculate.

Note the great increase in yield when alfalfa seed is inoculated.
Alfalfa With Inoculation.
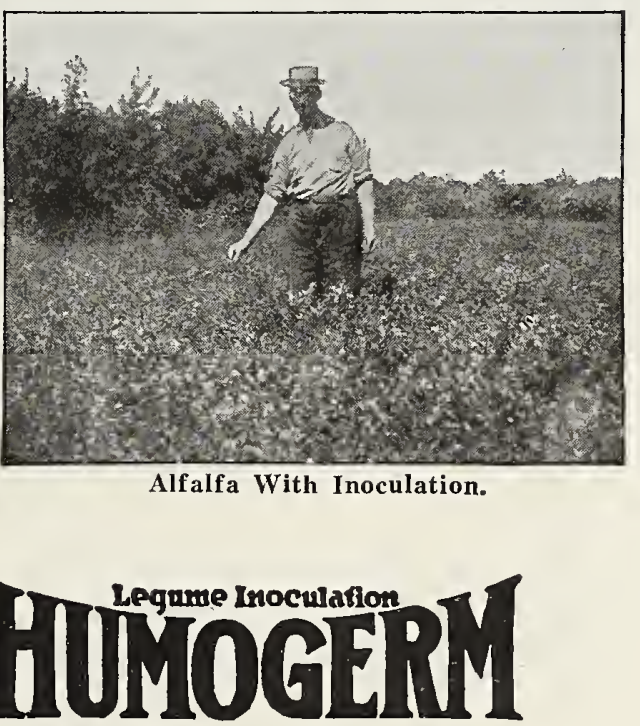

Farmogerm and Humogerm are now sold on bushel basis. (Note difference in price for small seeded legumes and Iarge seeded legumes.)

SMALL SEEDED LEGUMES

Alfalfa and all varieties of Clover.

$1 / 4$-bushel size.............. .35

$1 / 2$-bushel size.................6

1-bushel size............... 1.00

$2 \frac{1}{2}$-bushel size................ 2.25

Garden size for Garden Peas, Garden Beans, and Sweet Pea

\section{LARGE SEELED LEGUMES}

Soy Beans, Cowpeas, Vetch, Garden Peas and Beans.

$1 / 2$-bushel size..............\$ .35

1-bushel size.................

5 -bushel size............... 2.25

Remember we deliver free at catalogue prices-except where noted. Write for special prices in large quantities. 


\section{LAWN GRASS SEED}

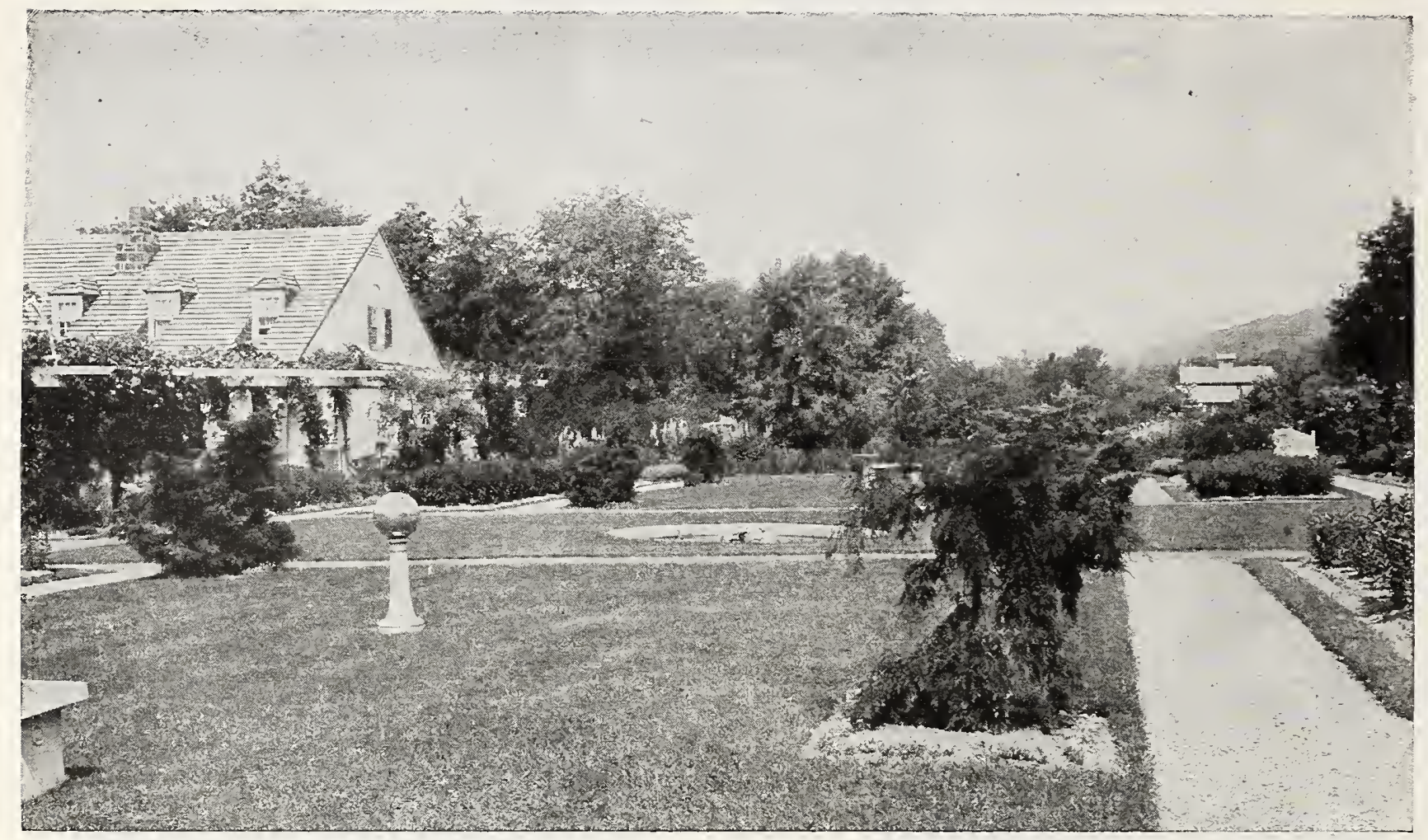

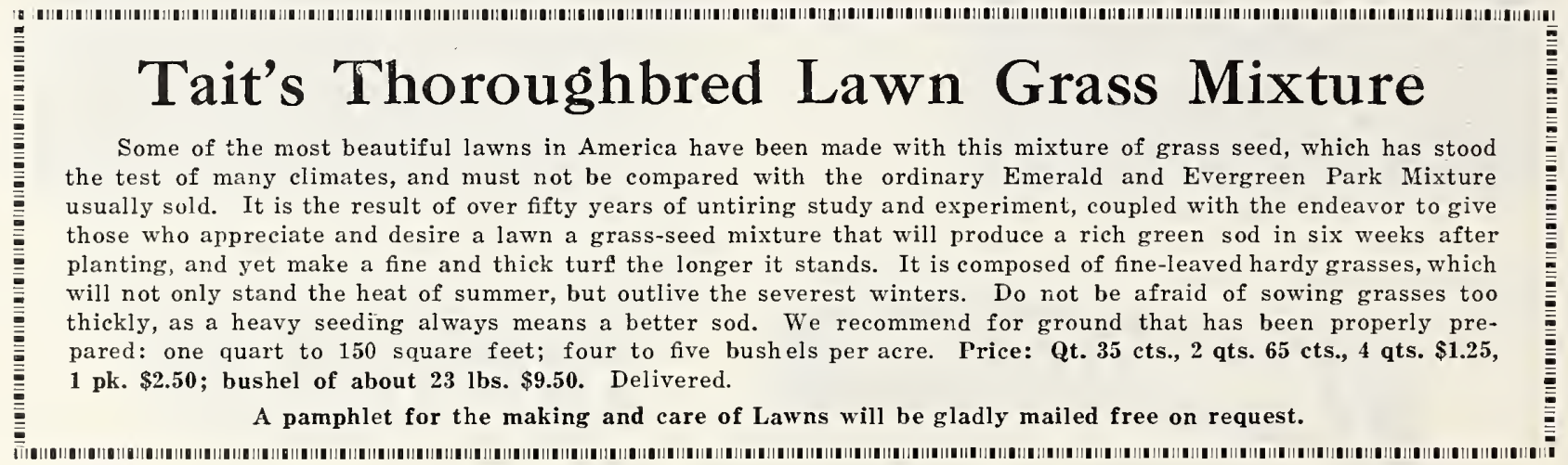

Tait's Seaside Mixture. A mixture of fine grasses peculiarly suited to seashore lawns. Price: Qt. 40 ets., 2 qts.

Tait's Shady Mixture. A mixture of grasses that thrive in shaded situations, under trees, or close to walls where $\$ 10.00$. Delivered. Tait's Terrace Mixture. A mixture of fine stoloniferous grasses peculiarly adapted to terraces. Price: Qt. 40
cts., 2 qts. 75 cts., 4 qts. $\$ 1.40$, pk. $\$ 2.75$, bus. of 20 lbs. $\$ 10.00$. Delivered.

Remember we deliver free at catalogue prices-except where noted. Write for special prices in large quantities. 


\section{SPECIAL MIXTURES FOR GOLF LINKS \\ AND POLO GROUNDS}

Tait's Golf Links Mixture. A mixture of hardy grasses, adapted to golf courses. Price, per bus. of $20 \mathrm{lbs}$. $\$ 9.00$.

Tait's Putting-Green Mixture. A mixture of extra-fine grasses that will make a close, firm, green and lasting . turf, which improves with trampling. Price, per bus. of 20 lbs. $\$ 12.00$. Delivered. Tait's Fair-Green Mixture. A mixture for the grounds in general. Price, per bus. of 20 lbs. $\$ 9.00$. Delivered. Tait's Polo-Grounds Mixture. A mixture of fine-leaved and deep-rooting grasses, forming a strong and lasting

\section{GRASSES AND GLOVERS}

The ideal time for sowing Grass and Clover Seeds is from March to May in

the Spring and from September to November in the Fall, except where noted.

As a rule, most people are far too careless with regard to the quality of the grass and clover seeds which they buy. It requires an experienced eye to detect the various grades of these seeds, and, indeed, it is no uncommon thing for us to meet persons who are entirely ignorant that different grades exist. To them clover is clover, whether it be old or new, pure or full of noxious weeds. Like everything else, grasses and clovers may be had to order at any price, but the farmer who thinks that he has saved money by buying cheap seeds needs feel no surprise if he fails in getting a stand, or if his fields are covered the next season with weeds previously unknown.

We desire to call especial attention to the fact that grass and clover seeds are usually offered for sale in three grades of quality-prime, choice, fancy-according to purity, germination and weight, and that the price of the best grade is considerable higher than the ordinary grade, and is always worth the difference. We handle only the very highest grade. The purity and freshress of our grasses and clovers may be relied upon with the same confidence that is universally felt with regard to the garden seed sent out by us.

The market prices of these seeds are constantly changing; quotations by mail or wire furnished upon application. They are sold strictly net cash, "F. O. B. Norfolk," quotations subject to change without notice.

\section{GRASSES}

Bent, Creeping. (Agrostis Stolonifera)-A rapidly spreading habit, deep green and fine leaved foliage make it very useful for fine lawns and putting greens. Prefers a moist soil. Height 12 to 18 inches. Bu. 14 lbs. Sow 50 lbs. to the acre. Write for prices.

Bent, Rhode Island. (Agrostis Canina)-Another though the foliage is not so deep a green as the above variety. Adapts itself to almost any soil. Height 12 to 18 inches. Bu. $16 \mathrm{lbs}$. Sow $40 \mathrm{lbs}$. to the acre. Write for prices.

Bermuda. (Cynodon Dactylon)-For hot and dry locaed. Does best when sown in warm weather, preferably in May and June. Height 6 to 12 inches. Bu. 36 lbs. Sow 10 lbs. to the acre. Write for prices.

Blue, Canada. (Poa Compressa)-A hardy perennial Blue, Canada. grass adapted to sandy and gravelly soils. For pasture and dairy use is well adapted to the eastern and middle states. Height 10 to 18 inches. Bu. $14 \mathrm{lbs}$. Sow $40 \mathrm{lbs}$. to the acre. Write for prices.

Blue, Kentucky. (Poa Pratensis)-This well known come thoroughly established, but when once well set, will last indefinitely and improve each year, enduring the hottest summers. While of too short a growth for hay, as a pasture grass it is extremely valuable, very productive, and nutritious. Its smooth, even growth, spreading habit, fine texture and rich green color make it one of the best grasses for lawns. Height 10 to 18 inches. Bu. $14 \mathrm{lbs}$. Sow $35 \mathrm{lbs}$. to the acre. Write for prices.

Carpet Grass Known also as Louisiana Grass, and recthe South for pastommended for the Coastal Plain area of grass. It should only be sown in the when sown with Japan Clover. It should be sown from early spring until late summer. Bu. $28 \mathrm{lbs}$. Sow $15 \mathrm{lbs}$. to the acre. Write for prices.

Crested Dogs-Tail. (Cynosurus Cristatus)-A useful splendid grass for fine lawns. Does well in shaded situations. Height 12 to 18 inches. Bu. 30 lbs. Sow 30 lbs. to the acre. Write for prices.

Fescue, Meadow. (Festuca Pratensis)-For permanent will prove very satisfactory. It does not aitain its full productive power until 2 or 3 years after sowing. Succeeds best in cold, moist light soil. Height 3 feet. Bu. $22 \mathrm{lbs}$. Sow 40 lbs. to the acre. Write for prices.

Fescue, Red or Creeping, True. (Festuca Rubra) rooted species thrives on all sorts of soil, forming a close and lasting turf. Is very valuable as a lawn grass for shady spots. Height 18 to 24 inches. Bu. 22 lbs. Sow 40 lbs. to the acre. Write for prices.

Fescue, Sheep's. (Festuca Ovina)-Grows on middling used when the soil is too shallow and poor to support grasses like Orchard and Tall Meadow Oat. Height 6 to 12 inches. Bu. $22 \mathrm{lbs}$. Sow $40 \mathrm{lbs}$. to the acre. Write for prices.

Remember we deliver free at catalogue prices-except where noted. Write for special prices in large quantities. 
Fescue, Tall Meadow (Festuca Elatior)-A splendid hay and pasmonclye, Tall Meadow. ture grass, and in rich moist soil is enormously productive. Height 24 to 36 inches. Bu. $20 \mathrm{lbs}$. Sow $40 \mathrm{lbs}$. to the acre. Write for prices.

Herd's-See Red Top.

Lawn Grass-See page 60. Millet, Golden. (Setaria Italica Var)-Golden Millet should never be makes an enormous yield of hay, and is usually in the best condition for cutting within 50 days after sowing. A favorite use for it is in following early potatoes. Never put millet on poor ground. Bu. 50 !bs. Sow 50 to 75 lbs. to the acre from May to August. Write for prices.

Millet, Hungarian. (Setaria Italica)-This variety is earlier, of finer Milet, Hungarian. quality, but less vigorous than the Golden. In dry summers it makes an exceedingly short growth, and few farmers care to grow it. Bu. 50 lbs. Sow 50 lbs, to the acre May to August. Write for prices.

Millet, Pearl or Cat-Tail. (Penicillaria Spicata) - A most valuable drills, or 25 lbs. broadcast from May to July. Write for prices.

Oat, Tall Meadow. (Avenna Elatior) - This very valuable grass proSouthern states is very mueh used for' pastures and hay. It is much relished by cattle. Height 24 to 36 inches. Bu, $12 \mathrm{lbs}$. Sow 40 lbs, to the acre. Write for prices.

Orchard. (Dactylis Glomerata)-One of the grasses most employed in rchard. permanent meadows, either for pasture or mowing. It is very hardy, and thrives better than any other grass in nearly all sorts of climate and soil. The hay is of excellent quality, and it will endure considerable shade. Cutting should be done while it is in flower, as its stalks have a tendency to go hard at maturity. Height 24 to 26 inches. Bu. 14 lbs. Sow 35 lbs. to the acre. Write for prices.

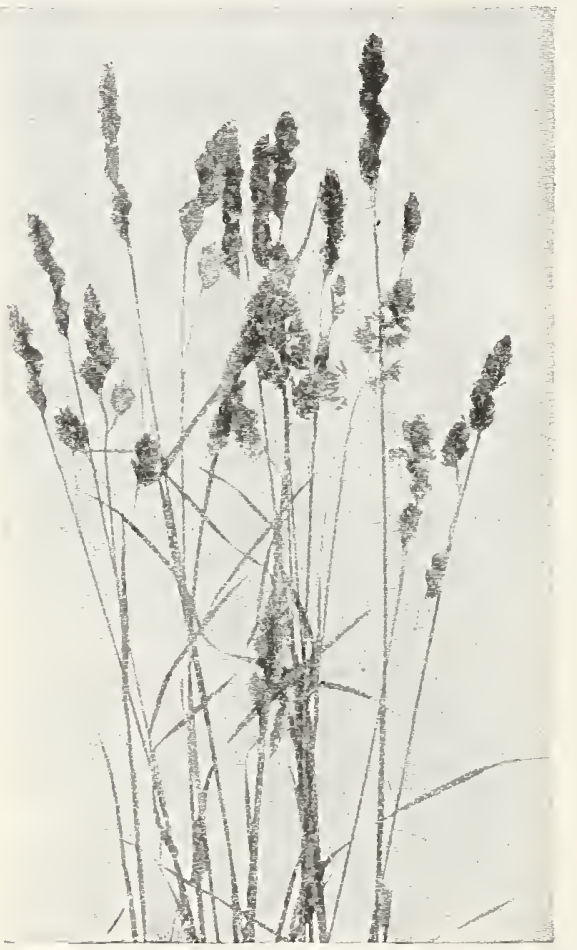

Orchard Grass.

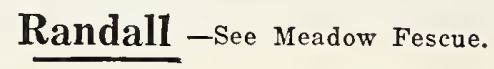
Red Top, or Herd's. (Agrostis Vulgaris)-While this hardy native however. will do well on a variety of soils, even dry situations. Sown alone or in mixture it makes a very fine permanent pasture. Height 18 to 30 inches. Bu. $40 \mathrm{lbs}$. Sow $15 \mathrm{lbs}$, to the acre. Write for prices.

Rye, English or Perennial. (Lolium Perenne)-Succeeds well on almost all cultivated soils, and produces a strong growth 4 or 5 weeks after sowing. Height 18 to 30 inches. Bu. $28 \mathrm{lbs}$. Sow $50 \mathrm{lbs}$ to the acre. Write for prices.

Rye, Italian. (Lolium Italicum)-While lasting only one year, this .ye, rapidly growing and productive grass is coming more and more into general use, especially for winter and spring grazing. It thrives on almost any soil. Height 18 to 30 inches. Bu. 24 lbs. Sow 50 lbs. to the acre. Write for prices.

Sweet Vernal. (Anthroxanthum Odoratum)-A wonderfully fragrant grass when dried. Although a valuable pasture grass, it is usually sown to sweeten hay. Height 12 to 24 inches. Sow 5 lbs. to the acre in mixture with other grasses. Write for prices. 


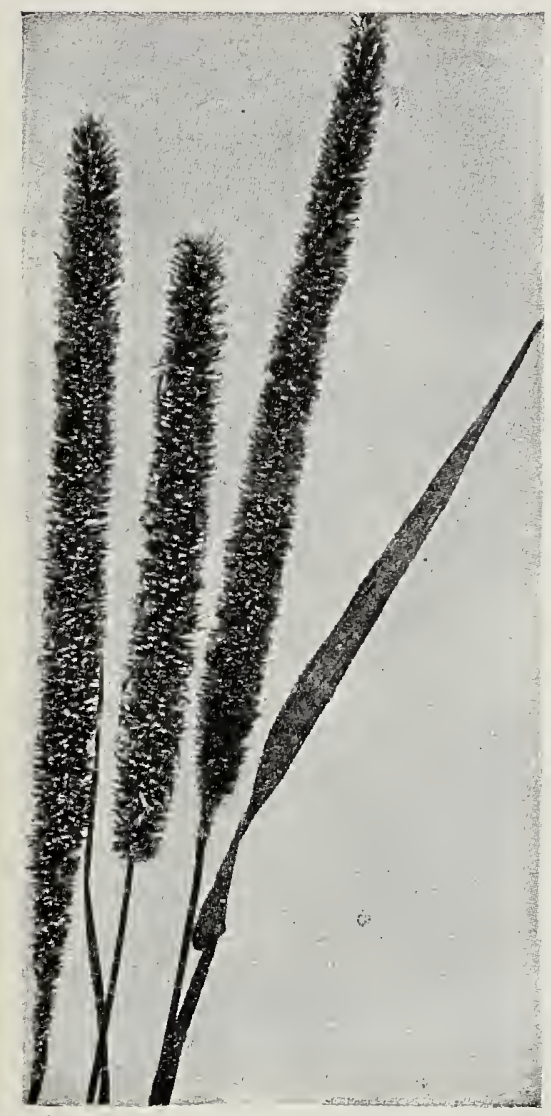

Timothy Grass. Timothy. (Phleum Pratensis)-This well known grass succeeds best in excessively dry and sandy. While generally sown by itself, it is often mixed with clover and Red Top. Height 18 to 30 inches. Bu. 40 lbs. Sow 25 lbs. to the acre. Write for prices.

Wood Meadow. (Poa Nemoralis)-The deep green color, exceptionally fine meaf and stalk, and its special fitness for shaded places make this variety a splendid kind for shaded places in lawns and woodland parks. Height 18 to 20 inches. Bu. $19 \mathrm{lbs}$. Sow $30 \mathrm{lbs}$. to the acre. Write for prices.

\section{Special Grass Mixtures For Meadows and Pastures}

We have many inquiries from those who have been led to buy ready-made mixtures, or made experiments of their own, and have found that certain varieties of grass will do better than others on their land. As it is nearly impossible to make a mixture that will be satisfactory until the location, condition of soil, and purpose for which wanted are known, we shall be pleased to have our customers consult with us regarding varieties suitable for their particular land; or, if they have certain varieties to include in their mixture, we are only too pleased to serve them in this way, for we have, on pages 61 to 64 , a very complete list of fancy varieties of grasses and clovers, of which we always carry a large stock, and will put up any mixture desired. We have facilities for executing all such orders promptly.

\section{G L OV E R S}

Alfalfa, or Lucerne. (Medicago Sativa)-One can hardly estimate the per acre each season is generally four or five cuttings of about two tons each. The hay is remarkably palatable and the feeding $\mathrm{v}$ a l u e has been scientifically estimated to be worth nearly twice that of the very best $\mathrm{T}$ i mot h y. Drou ghts which would either destroy or quite stop the growth of ordinary plants have no effect upon Alfalfa, as its roots penetrate to astonishing depths in search of moisture. and the effect upon the land is highly beneficial. Alfalfa can be sown in either fall or spring. The cleaner the ground, the better the stand will be, as young Alfalfa is so slender and delicate that it is easily smothered by weeds. Sow on deep, well drained, good loamy land. Alfalfa will not grow on acid soils, and to correct this condition spread 1 to $1 \frac{1 / 2}{2}$ tons of finely ground lime to the acre after plowing. and a few weeks before sowing. Cutting should be done always as blooming begins. Bu. $60 \mathrm{lbs}$. Sow 30 to $40 \mathrm{lbs}$. to the acre. Write for prices.

\section{TNOCULATE THIS SEED WITH MULFORDCULTURE}

Alsike. (Trifolium Hilbridum) - A very hardy variety Alsike. and will withstand extremes of heat, drought and cold better than any other clover. Owing to its tendency of lying down on the ground and its somewhat bitter taste, it should always be sown in mixture with other clovers and grasses. Does well on soil which is too acid or moist for other clovers. Bu. $60 \mathrm{lbs}$. Sow $12 \mathrm{lbs}$. to the acre. Write for prices.

Bokhara, or Sweet. (Melilotus Alba)-This bied to almost any kind of soil, grows from 3 to 5 feet high, and on rich soil can be cut three times. Bu. 60 lbs. Sow 15 lbs. to the acre. Write for prices.

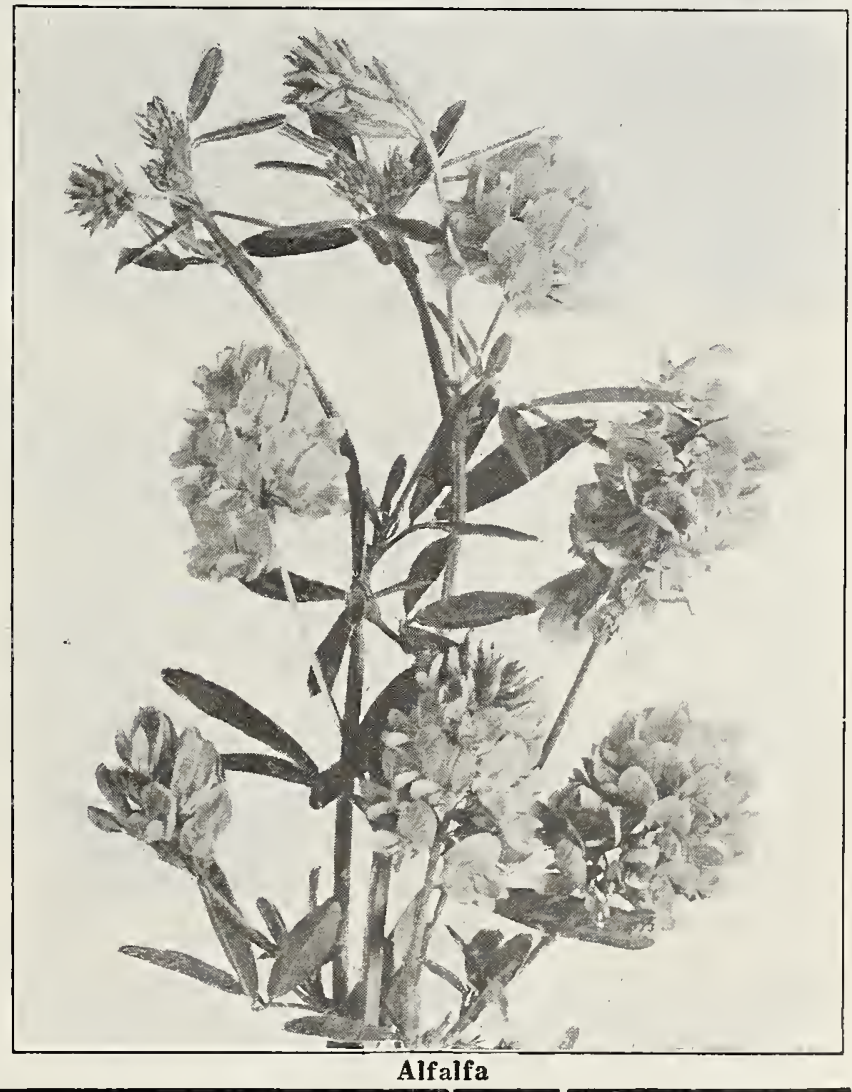

where noted. Write for special prices in large quantities. 
Burr. (Medicago Moculata.) In the South for winter and Burr. early spring pasturage, this is most valuable. It grows rapidly, and is liked by all stock. In the far south, when sown with Bermuda Grass, the two make a splendid allthe-year-round pasturage. It reseeds itself, and improves in growth each succeeding year. Bushel cleaned, $60 \mathrm{lbs}$. In the burr, 14 lbs. Sow 15 lbs, to the acre. Write for prices.

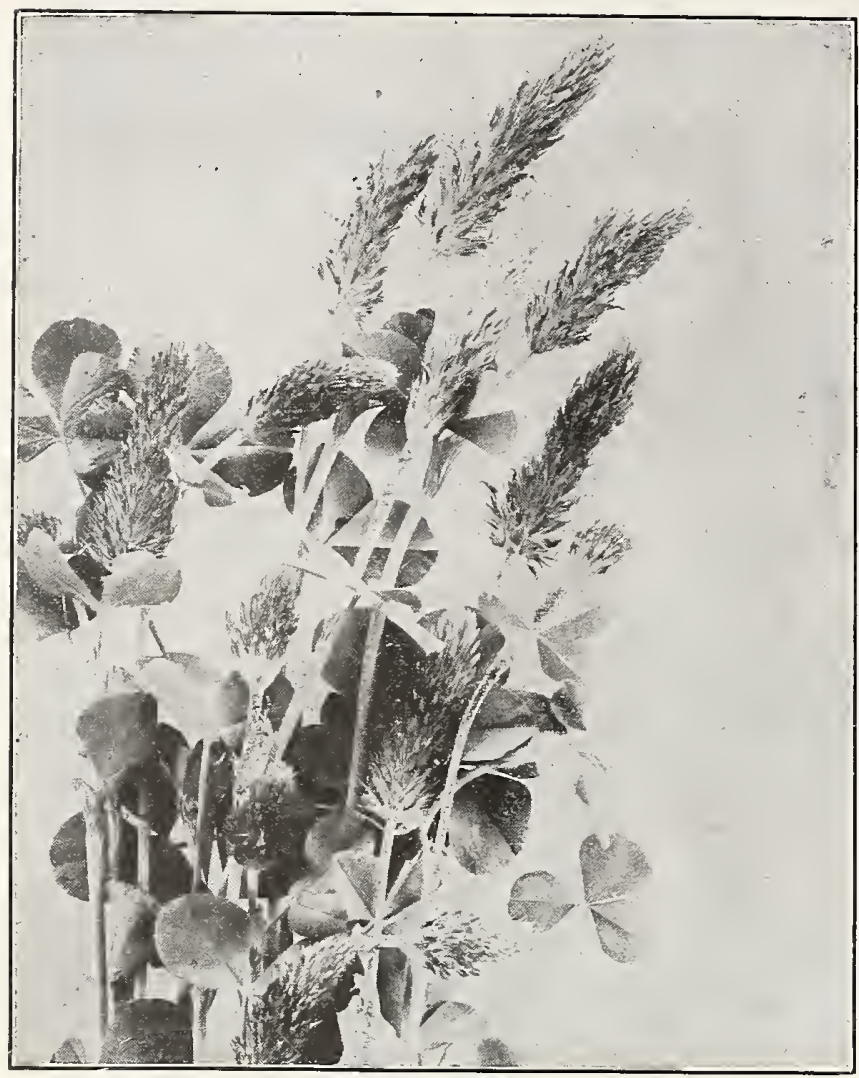

Crimson Clover.

Crimson. (Tryfolium Incarnatum.) This valuable variety Crimson. grows from $1 \frac{1 / 2}{\text { to }} 3$ feet high, and has long cone-shaped dark red blossoms. The stem is smaller than that of Red Clover and is apt to fall over unless supported by rye or some stronger plant. Sowing is begun during the last of July and continues until the last of October. Farther South it can be sown later. A common practice is to sow the seeds in furrows of corn and cotton fields at the time of the last cultivation. Prepare the land sometime previous to sowing and wait for a rain, and as soon as the land is dry enough, break the crust with a light harrow, sow the seeds and cover lightly. The seed always make a much better start in land which has been worked shortly before and needs nothing more than the harrow. The seed should not be covered deeply, and in dry weather rolling is very helpful. For winter pasturage there is nothing better than a mixture of Rye and Crimson Clover. The plant is an annual, and re-sowing every year is necessary. Bu. $60 \mathrm{lbs}$. Sow $20 \mathrm{lbs}$, to the acre. Write for prices.

Crimson, White Blooming. Two or three weeks Clover, and has a white blossom. Bu. $60 \mathrm{lbs}$. Sow 20 lbs. to the acre. Write for prices. Japan. (Laspedeza Striata.) This is a perennial, and quality is its ability to last through the dryest seasons in soils which would support nothing else. Often used in mixtures with Carpet Grass for pastures. Bu. 25 lbs. Sow 25 lbs, to the acre. Write for prices.

Red, Mammoth. (Tryfolium Pratense Perenne.) Known also as Pea-vine, Sapling Clover, and Cow Grass. It is a vigorous perennial, and grows from 4 to 6 feet high. The stalk is coarse when cured, and stock usually reject all except the leaves. Bu. $60 \mathrm{lbs}$. Sow $15 \mathrm{lbs}$. to the Wite for prices.

Red, Medium. (Tryfolium Pratense.) This well known clover is indispensable on every well managed farm. It not only furnishes fine pasturage and excellent hay crops, but it is one of the cheapest and most effective mediums for improving worn out lands. Its enormous root development greatly loosens and ventilates the earth and the turning under of the entire plant is very beneficial on account of the humus obtained. Red Clover on good land will yield two cuttings a year, and should be cut for hay when in full bloom. The finest permanent nastures are made by sowing it with Orchard Grass, Tall Meadow Oat Grass, or the Fescues, a favorite mixture being $15 \mathrm{lbs}$. Orchard, $12 \mathrm{lbs}$., Tall Meadow Oat, 8 lbs. Clover. Sow either in the fall or spring. Avoid cutting or pasturing too close in late summer or autumn, as more or less foliage is required for protection during the summer or winter. Bu. $60 \mathrm{lbs}$. Sow $15 \mathrm{lbs}$. to the acre. Write for prices.

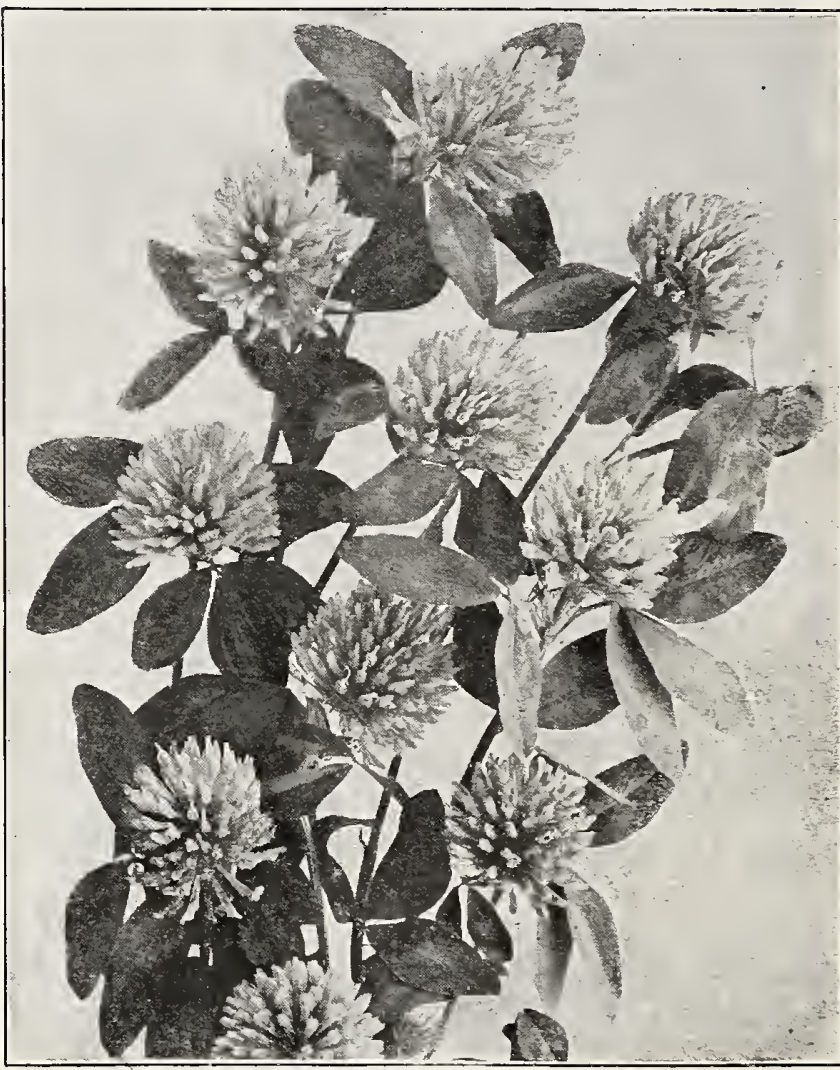

Medium Red Clover.

\section{Sweet White Blooming. See Bokhara.}

White Dutch. (Tryfolium Repens.) Every permanent White Dutch. (Tasture should have some white clover. It is adapted to all soils, and makes a small, close, compact growth covering the ground like a carpet. Bu. 60 lbs. Sow $10 \mathrm{lbs}$. to the acre. Write for prices. 
Seeds of all undermentioned varieties, descriptions and prices may be readily found in the Catalogue by referring to Index. FLOWERING ANNUALS-That attain perfection and flower the first season from seed.

\begin{tabular}{l|l|} 
†Asters & $\dagger$ Calliopsis \\
Ageratum & †Candytuft \\
†Alyssum & Carnation \\
†Antirrhinum & †Celosia \\
Agrostemma & Centaurea \\
Balsams & Chrysanthemum \\
Begonia & Clarkia \\
Browallia. & Collinsia \\
†Calendula & Cornflower
\end{tabular}

Balloon Vine
Canary Bird Vine
Cobaea

\begin{abstract}
Convolvulus Cypress Vine Dolichos
\end{abstract}

Varieties marked
Cosmos
Dahlia
Dianthus
Eschscholtzia
Feverfew
Four o'Clocks
†Gaillardia
Globe Amaranth
Godetia

\begin{tabular}{|l|} 
Gypsophila \\
Helichrysum \\
Heliotrope \\
Kochia \\
Lantana \\
Larkspur \\
Lavatera \\
Linaria \\
Tobelia
\end{tabular}

massing in bed
Lupinus
Lychnis
† Marigold
Mignonette
† Nasturtium
Nicotiana
$\dagger$ Petunia
†Phlox
Pinks

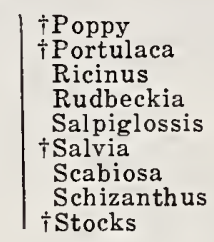

Sunflower Sweet Peas Sweet Sultan $\doteqdot$ Terbena

Vinca

Virginia Stocks Wallflower $\dagger$ Zinnia

\section{ANNUAL CLIMBING VINES}

\begin{abstract}
Gourds Hyacinth Bean Japan Hop
\end{abstract}

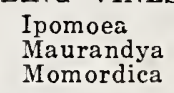

\section{Moonflower \\ Morning-Glories \\ Nasturtiums}

\section{Sweet Peas}

Thunbergia

\section{FLOWERING HARDY PERENNIALS}

\begin{abstract}
Alyssum, Hardy
Aquilegia

Bellis

Candytuft, Hardy

Canterbury Bells

Carnation
\end{abstract}

Aquilegia

Asters

Calliopsis

Carnations

For permanent beds,

\begin{tabular}{l|l} 
Centaurea, Hardy & Digitalis \\
Chrysanthemum, & English Daisy \\
Hardy & Forget-me-not \\
Coreopsis & Foxglove \\
Dianthus, Hardy & Gaillardia \\
Delphinium & Gypsophila
\end{tabular}

\begin{tabular}{|l|l|} 
Hollyhocks & Pansies \\
Lobelia, Hardy Sorts & Penstemon \\
Lupinus, Hardy Sorts & Phlox, Hardy \\
Lychnis & Pinks, Hardy \\
Myosotis & Poppy, Hardy \\
Paeonia &
\end{tabular}

Pyrethrum, Hardy Rudbeckia, Hardy Scabiosa, Hardy Statice, Hardy Sweet William

\section{LONG STEMMED FLOWERS SUITABLE FOR CUTTING}

\begin{tabular}{l|l|l|l|l}
$\begin{array}{l}\text { Centaurea Sweet } \\
\text { Sultan }\end{array}$ & Dahlia & Gypsophila & Matricaria & Scabiosa \\
Chrysanthemum & Dianthus & Lantana & Mignonette & Schizanthus \\
Coreopsis & Larkspur & Poppies & Snapdragon \\
Cosmos & Gaillardias & Lavatera & Rudbeckia & Sunflower \\
Heliotrope & Marigold & Salpiglossis &
\end{tabular}

Sweet Peas Sweet Sultan Sweet William Wall Flower

Zinnias

\section{PLANTS SUITABLE FOR EDGINGS}

Ageratum

Centaurea

Verbena

Alyssum

Phlox

Lobelia Compacta

\section{Pinks (hardy) \\ Portulaca}

Asters, (Dwarf)

Bellis

Nasturtium

\section{Pyrethrum Candytuft Petunia}

Sweet William Zinnia

\section{PLANTS SUCCEEDING IN PARTIAL SHADE}

Antirrhinum

Delphinium

Pansy

Amaranthus Tricolor Coleus

Maurandia

Centaurea (Cornflower)

\begin{abstract}
Aquilegia
Digitalis

Poppies
\end{abstract}

\author{
Bellis \\ Matricaria \\ Feverfew
}
Canterbury Bells
Mimulus
Coreoposis

\section{Myosotis}

COLORED FOLIAGE PLANTS FOR BORDERS AND RIBBON BEDS

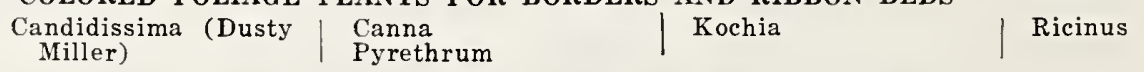

PLANTS FOR VASES, HANGING BASKETS, VERANDA BOXES, ETC. Nasturtium
Coleus
Petunia Geranium
Heliotrope

Alyssum
Pansy

Smilax

Smilax

\section{TAIT'S THOROUGHBRED FLOWER SEEDS}

$\mathrm{Y}$

OUR HOME and grounds can be made beautiful by using TAIT'S FLOWER SEEDS. They are given that same care and attention which have made our THOROUGHBRED VEGETABLE SEEDS famous. They are all from the very best sources of supply and are of the highest possible merit.

\section{ABRONIA}

A charming trailing plant with sweet-scented lilac flowers formed in a head like that of the Verbena, and is very useful for hanging baskets. The husk should always be removed from the seed before sowing in order to facilitate germination. Half-hardy annual. 5 inches. Pkt. 10 cts., oz. $\$ 1.00$.

\section{ACROCLINIUM}

One of the most beautiful of the Everlastings, robust in habit, and adapted to almost any good soil. The flowers are shaped much like field daisies, and are either white or a lovely rose-color. Half-hardy annual. 2 feet. Mixed. Pkt. 5 ets., oz. 60 cts.

\section{AGERATUM (Floss Flower)}

One of the most desirable summer flowering plants we have. It may be used alone for beds and borders, or planted in connection with geraniums, coleus, etc. Half-hardy annual. 8 to 12 inches. Pkt. 10 cts., oz. $\$ 1.00$.

\section{AGROSTEMMA (Rose of Heaven)}

Sometimes called the Mullein Pink. This perennial blooms the first season. The flowers are produced on long slender stems, and are fine for cutting. Hardy perennial. 2 feet. Mixed. Pkt. 10 cts., oz. $\$ 1.00$.

Remember we deliver free at catalogue prices-except where noted. Write for special prices in large quantities. 


\section{ALXSSUM (Sweet or Mad Wort)}

Sweet Alyssum is of the easiest culture both indoors and out, and is suitable alike for beds and edgings in summer, or for growing in pots or boxes for winter blooming. The flowers are white and fragrant. 3 to 6 inches. Hardy annual.

Carpet of Snow. A very select strain, plants grow $2 \frac{1}{2}$ inches high and about 12 to 18 inches in diameter. The of being covered with snow. Plit. $10 \mathrm{cts}$, oz. $\$ 1.25$.

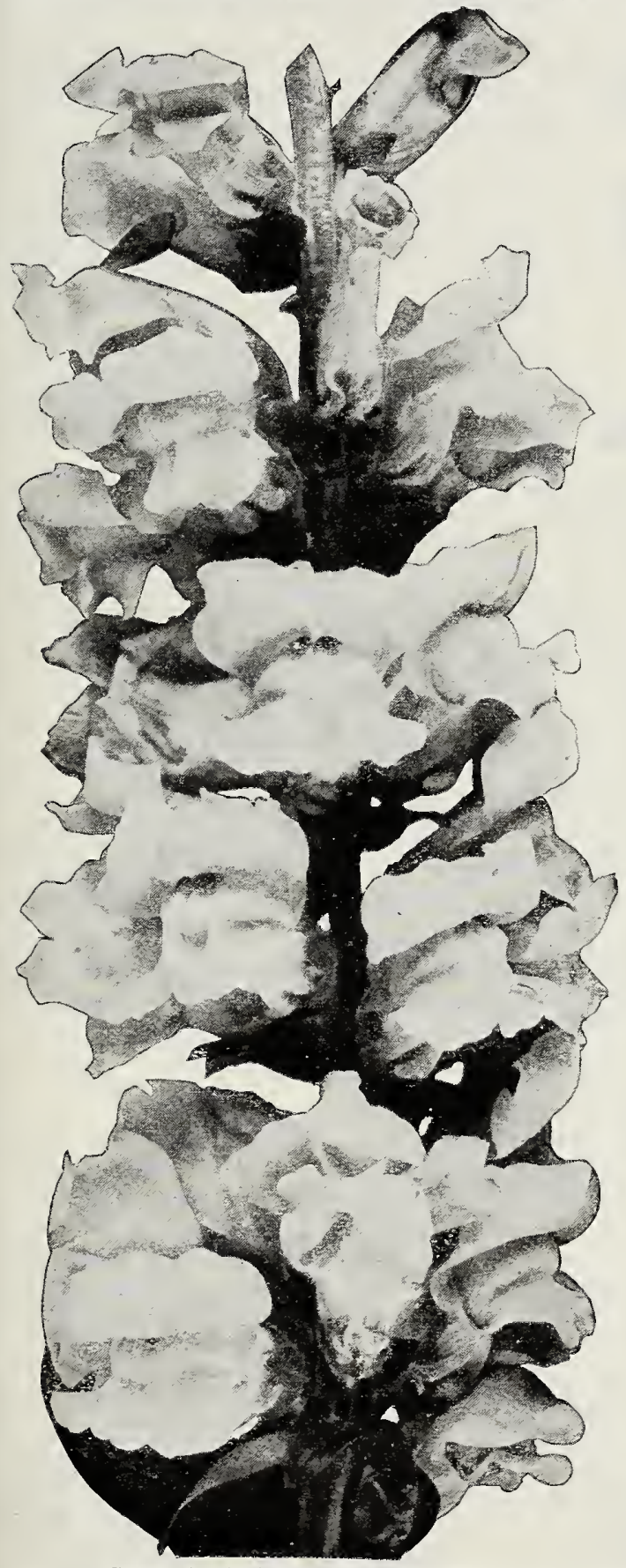

Giant Antirrhinum (Snapdragon).
Little Gem. Plants very dwarf and spreading, growing only 3 Maritimum. The common variety, very fragrant. Pkt. 10 cts., oz. $\$ 1.00$.

\section{AMARANTHUS}

Strong growing, highly ornamental annuai plants of easy culture. They do best in rich loam soil.

Caudatus, long drooping blooms, color bright red. 3 feet. Globe. The flowers of this familiar old Amaranthus are produced colors. 2 feet. Mixed. Pkt. 5 cts., oz. 60 cts.

Salicifolius. The leaves are about a foot in length, and $1 / 4$ changes from green to orange red. 4 feet. Pkt. 10 cts., oz. $\$ 1.00$. \begin{tabular}{l} 
Tricolor. (Joseph's Coat). Showing red, vellow and green leaves. \\
\hline
\end{tabular}

\section{ARCTOTIS GRANDIS}

The large daisy-like blooms of this hardy annual are fine for cutting. It grows rapidly and the flowers are pure white, with bright blue center, surrounded by pale gold, the underside of the petals being pale lilac. Sometimes called "Blue-eyed African Daisy." Hardy annual. 3 feet. Pkt. 10 cts., oz. $\$ 1.00$.

\section{ANTIRRHINUM}

\section{(Beautiful New Giant Snapdragons.)}

This wonderful new group of Antirrhinums surpasses anything yet introduced. The flowers are of magnificent size and closely placed on the spike. They are one of our finest perennials, and if the seeds are sown early will bloom the first year. The flowers are nearly double the size of the old sorts. The plants are of healthy, robust growth, with deep, green foliage blooming freely and continuously. The blooming qualities, ease of cuiture, and pure bright colors, entitle them to a place in every garden. The rich spikes are beautiful for cutting, will keep fresh a long time, and few flowers are more decorative. Snapdragon have become immensely popular in recent years and can easily be grown from seed. Half hardy perennial. 2 feet.

APPLE BLOSSOM. Rosy pink, yellow lip.........\$.15 \$.25 BUNCH OF LILAC. Lilacy purple............... $15 \quad .25$ COPPER KING. Velvety copper scarlet...........15 $\quad .25$ OLD GOLD. Deep golden yellow.................... QUEEN VICTORIA. Large pure white............. .10

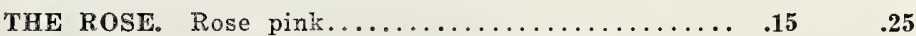
SILVER PINK. - Last word in pink Snapdragons..... SNOWFLAKE. Pure white, yellow tube............15 $\quad .25$ VENUS. Beautiful shell pink.................10 GLANT MIXED. A splendid mixture of all colors..... $.10 \quad \mathbf{. 1 5}$ GIANT STRIPED .......................... 10 


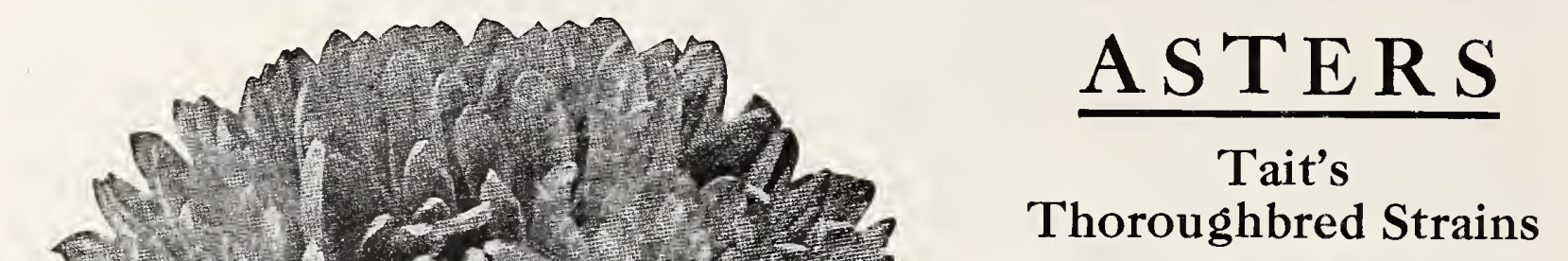

We suggest the use of Early, Mid-Summer and Late Kinds. With a little care in the selection of the varieties it is possible to have asters in bloom from the early part of July until late fall.

$\mathrm{N}$ beauty of form and color the Aster has few rivals among annuals, and their usefulness as cut flowers makes them fine for market as well as the home garden. We use the greatest care in our selections, and as a result our list comprises only the very best sorts. The varieties offered represent the finest Asters introduced to date, and should be in every garden where high quality is appreciated. The early sorts begin blooming in July, followed by the mid-season varieties, which are usually at their best in August. Then the Late Flowering types start the latter part of August and continue blooming until frost.

"Peerless Pink" Aster.

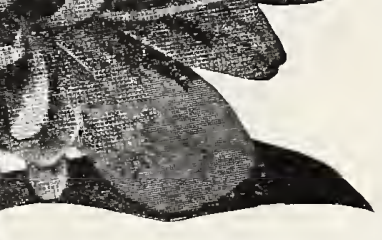

Asters will thrive in most any situation, but prefer one in which they get the morning sun. It is well to remember that any extra care taken in the preparation of the soil is repaid by finer plants, larger blooms with longer stems and more profuse flowering. They should have an open position, and prefer a good, heavy loamy soil, enriched with a liberal quantity of bone meal, or garden fertilizer. When wanted for cutting with long stems they should be set out not closer than twelve inches apart in the rows. For mass effect in beds they may be planted from 9 inches to a foot apart. To destroy the black aster beetle, which is the Aster's worst enemy, use Arsenate of Lead.

\section{Two Splendid Asters That Should Be in Every Garden "PEERLESS PINK" ASTER}

The finest pink late-branching Aster ever offered. The robust, free-branching plants, growing 24 to 30 inches high, bear the lovely blooms on long strong stems. The almost globular flowers often measure 5 inches by $21 / 2$ inches in depth. The color is a rich shell pink. They start blooming about the middle of August, being at their best during the early part of September. Pkt. 15 cts., 2 pkts. 25 cts.

\section{“SENSATION" ASTER}

This fine Aster is the reddest of all red Asters. The rich garnet or ox-blood red fairly glistens in the sunshine. The plants are of free-branching habit about eighteen inches high, and the very double flowers are borne on long stems from early in August until the close of September. Pkt. 15 cts., 2 pkts. 25 cts.

\section{Early Flowering Types QUEEN OF THE MARKET}

These well-known early flowering Asters are of branching habit, about 18 inches high, and are one of the most useful types for early market. They come into bloom in July, and the flowers, which are of good size, are borne on long stems, making them very valuable for cutting.

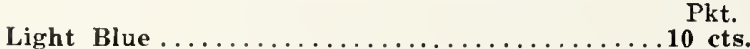

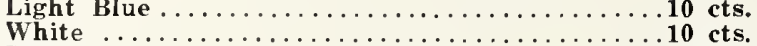

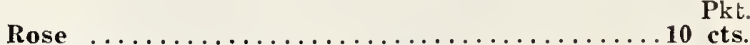

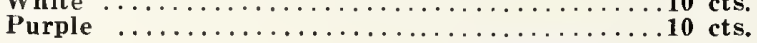

Crimson

COLLECTION. Packet each of Five varieties......40 cts.

\section{TRUFFAUT'S PEONY FLOWERED}

Flowers of medium size, with incurved petals. Plants are about $2 \frac{1}{2}$ feet high and erect in growth.

Light Blue.

Pkt.

.

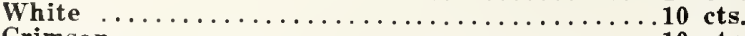

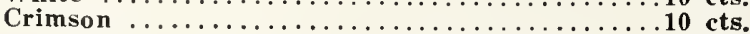

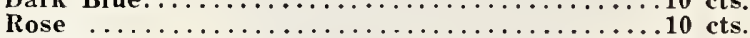

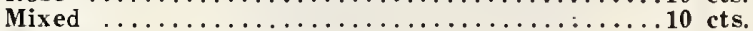

COLleCtion. Packet each of Five Colors........40 cts. 


\section{A STER S}

\section{Mid-Summer Flowering Types.}

Giant Crego. This is a fine variety for all Comet type, the twisted and curled petals give the flower the appearance of a huge flat chrysanthemum. They often measure 5 inches in diameter and are borne on strong, erect stems averaging 12 to 15 inches in length. Though the flowers are large they are produced in abundance. Plants robust, about 3 feet high.

Pkt.

Blue .......15 cts.

White $\ldots \ldots \ldots 15$ cts.

Purple...

$\ldots 15$ cts.

Crimson .....15 cts.

Mixed .......10 cts.

COLLECTION. Packet each Five Colors..60 cts. Ostrich Feather. This magnificent Aster mense size, having long, full fluffy flowers. The stems are long, and under good cultivation the flowers will measure as much as four inches in diameter. Plants about $2 \frac{1}{2}$ feet high and robust in growth.

Pkt.

Blue .......10 cts.

White ......10 cts.

Pink .......

COLLECTION. Packet each of 5 varieties. $40 \mathrm{cts}$.

\section{Late Flowering Types.}

Pkt.

Purple ......10 cts

Crimson .......10 cts.

Mixed .......10 cts.

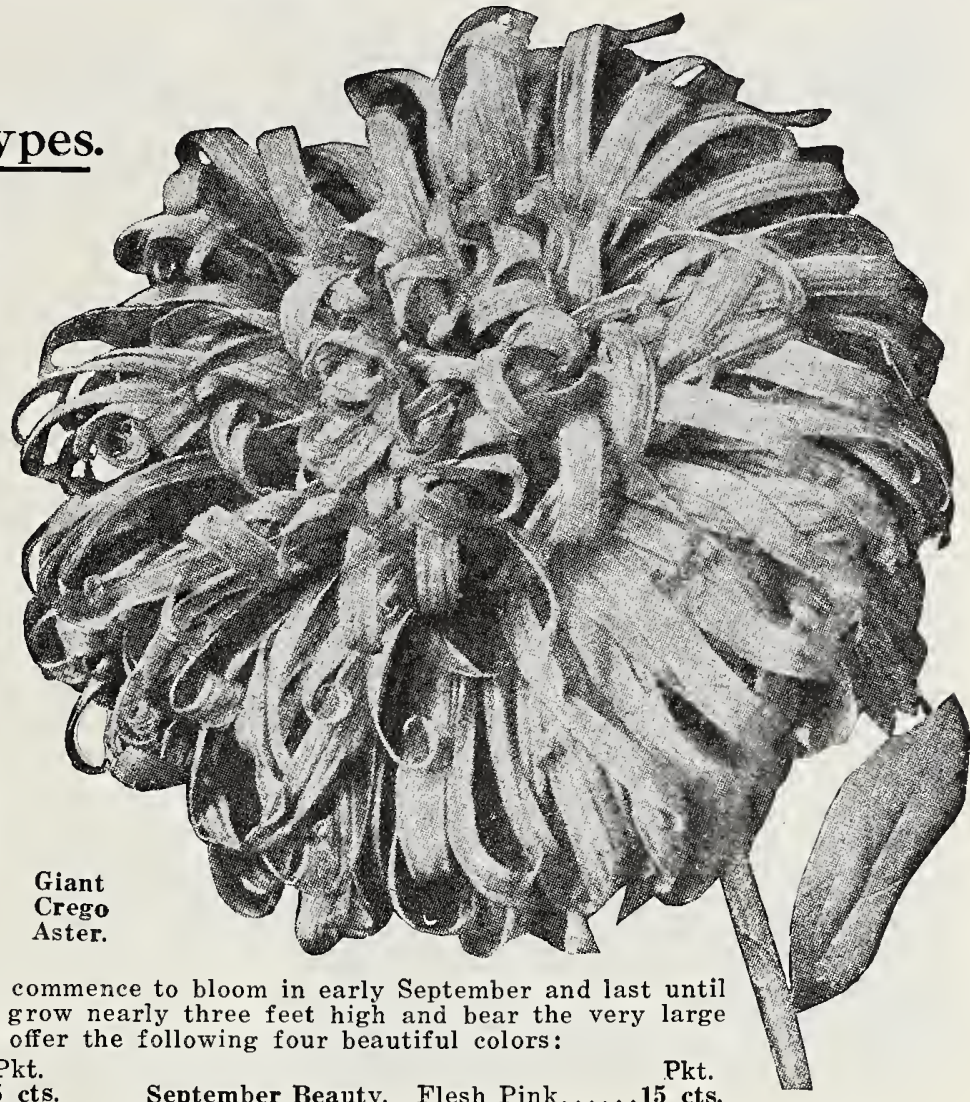

Pkt.

Rose Beauty...........................

September Beauty. Flesh Pink.....15 cts.

White Beauty. Giant White......15 cts.

\section{COLLECTION. Packet each of Four varieties.......50 cts.}

Giant Comet A good bedding variety, and is of vigorous growth. The fiowers are of large size, double and well Giant Comet。 formed. All the outer petals curve outward irregularly, giving a curious, but remarkably artistic effect. Plants of upright habit, about 3 feet high.

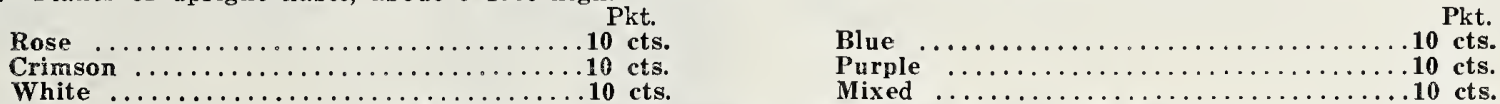

\section{COLLECTION. Package each of Five varieties......40 cts.}

American Branching. The plants form strong branching bushes, bearing the flowers on long, strong stems, American Branching. which, under ordinary cultivation, measure 5 inches in diameter. These are probably the most valuable Asters grown, either for cutting or for bedding, and are usually at their best during September and October. The plants, which are robust in habit, grow $2 \frac{1 / 2}{2}$ to 3 feet high.

Pkt.

White $\ldots \ldots \ldots \ldots \ldots \ldots \ldots \ldots \ldots \ldots \ldots \ldots \ldots \ldots \ldots \ldots$ cts

Lavender

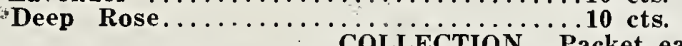

Crimson

Purple

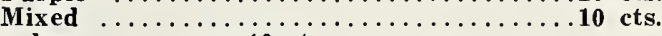
King Asters (Needled Type). The "King" Asters are of strong, sturdy, upright habit. Flowers large and double,

Crimson King...................

Pink King.....................

Lavender King.............. $10 \mathrm{cts}$. CoLLECTION. Packet each of Five Mixed
Pkt.

.10 cts.

10 cts.

10 cts.

BABY'S BREATH (See Gypsophiza).

BACHELOR BUTTON (See Matricaria).

BALLOON VINE (Love-in-a-Puff). A rapid growing, half-hardy annual climber. The white flowers are followed BALLON by balloon-like seed pods. 10 feet. Pkt. 5 cts., oz. 50 cts.

BALSAM. This old garden favorite, called "Lady Slipper," or "Touch-me-not," has been so improved that it is one (1) of the showiest and most popular of the summer annuals. The young plants are quick, sure growers, and Camellia Flowered. Beautiful double flowers of extra size. Mixed. Pkt. 10 cts., oz. 75 cts.
Cand

Remember we deliver free at catalogue prices-except where noted. Write for special prices in large quantities. 


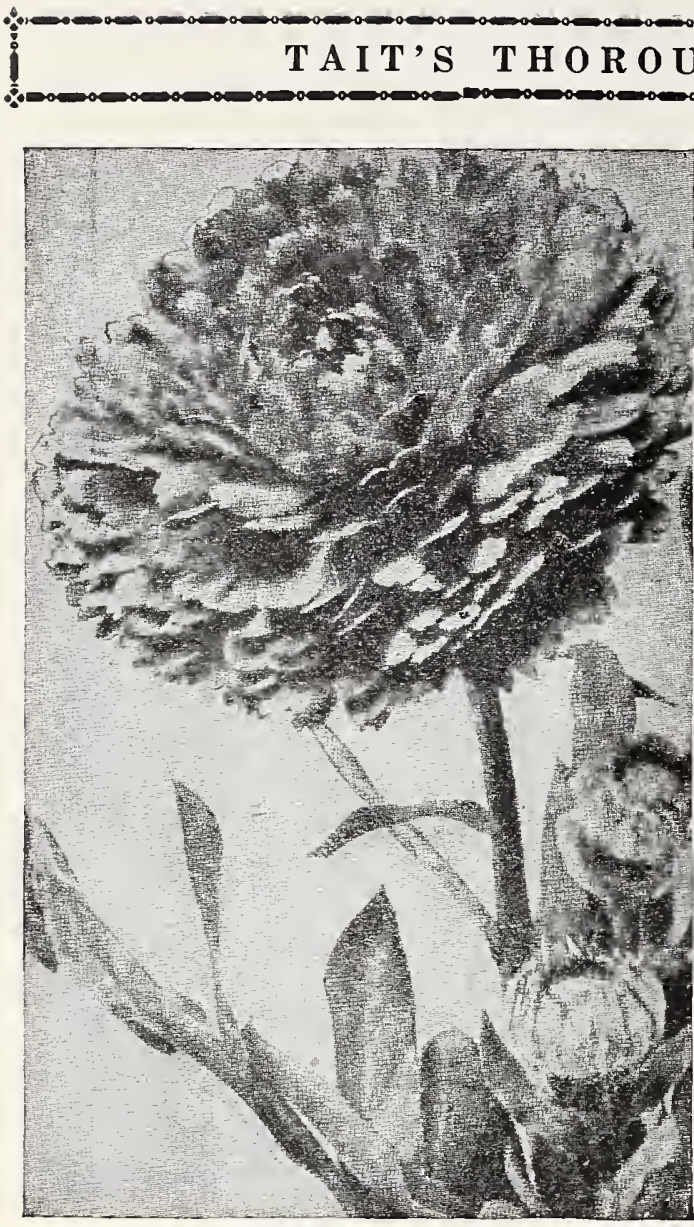

Calendula Orange King.
F LOWER SE E D S

\section{BALSAM PEAR}

The handsome leaves of this vigorous climber give quick and dense shade. The orange-colored fruit bursts open when ripe, and turns back, showing bright red seeds. Half-hardy annual. 12 feet. Pkt. 5 cts., oz. 60 cts.

\section{BLANKET FLOWER (See Gaillardia.) \\ BROWALLIA}

Beautiful free-flowering annuals. It is excellent for edgings or baskets, and may be potted for winter blooming. Half-hardy annual. 1 foot. Mixed. Pkt. 10 cts., oz. $\$ 1.00$.

\section{CALENDULA}

One of the most popular and easily grown of the hardy annuals. It flourishes under all conditions, and is in constant bloom until checked by very low temperatures. 1 foot.

Orange King. The plants of this specially selected strain atKing. tain a growth of eighteen inches, and produce blooms $3 \frac{1}{2}$ inches in diameter. The large double flowers are a rich, dark orange red. Pkt. 10 cts., oz. 60 cts.

Lemon Queen. Identical in every way to the preceding except 10 cts., oz. 50 ets.

Mixed Varieties. This mixture contains the striped sorts as well as the different yellow and orange shades. Pkt. 5 cts., oz. 35 cts.

\section{CANNA}

Quick growing plants with luxurious foliage and brilliant flowers. The seeds are so extremely hard that before planting they should be soaked for twelve hours in warm water. Half-hardy perennial. 3 to 6 feet. Mixed. Pkt. 10 cts., oz. 60 cts.

\section{CANNA ROOTS (See Page 88).}

\section{CANDYTUFT}

For solid beds, edgings or rockeries, candytuft is invaluable. The seeds should be sown thickly, where the plants are to remain, and by sowing in the fall, flowers may be had in profusion very early in the spring. Hardy annual. 6 inches to 1 foot.

\section{Giant Hyacinth Flowered or Improved}

Empress. This much improved strain of the popular EMPRESS Candytuft is much used for beds and borders, and is invaluable for cutting. The plant grows 18 inches high and produces enormous spikes of pure white flowers. Plit. 10 cts., oz. \$1.00.

Dwarf Hybrids. Persons who are familiar with only Dwarf Hybrids. white varieties will be surprised by the beauty of these gay hybrids. Mixed. Pkt. 10 cts., oz. $\$ 1.00$.

Little Prince. A dwarf Empress. Pkt. 10 cts., oz. \$1.00.

\section{PERENNIAL CANDYTUFT}

Dwarf, compact growing. hardy evergreen plants, making a magnificent showing the second year from seed.

Sempervirens. Completely covered with heads of

\section{CANTERBURY BELLS}

Attractive and showy biennials, which succeed best in rich well drained soils. As the plants grow to considerable size, branching widely, care should be taken in setting them out to allow not less than 2 feet each way.

Calacanthema. A strikingly handsome plant, and withfashioned garden plant. $2 \frac{1 / 2}{2}$ feet. Pkt. 10 cts., oz. $\$ 2.00$.

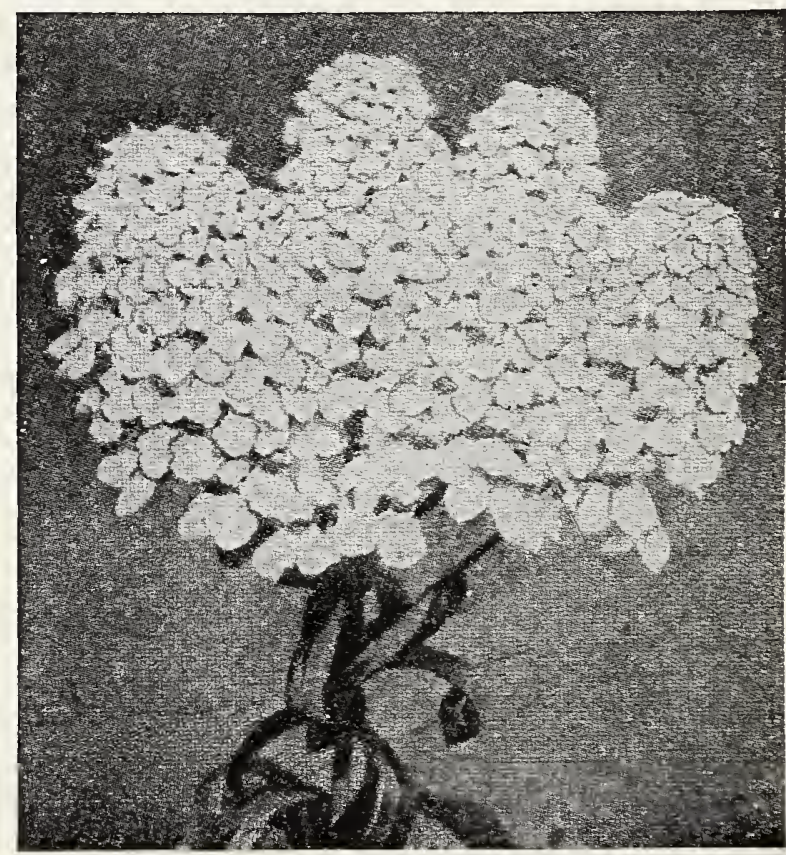

Giant Hyacinth Flowered Candytuft.

Remember we deliver free at catalogue prices-except where noted. Write for special prices in large quantities. 


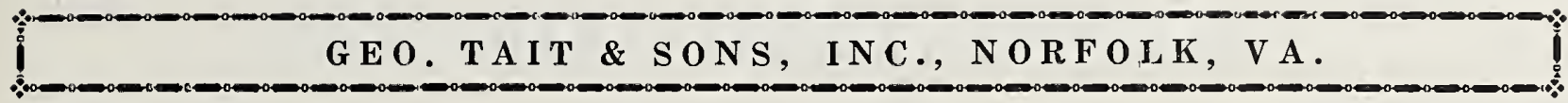

\section{CARNATION}

In the splendid strains of carnation we offer, a remarkably large percentage of the flowers will be doubled, all being more or less double. In the Southern States, carnations rarely require any protection whatever. The more expensive sorts produce the best flowers, and prices, although seemingly high, are most reasonable for strains such as we offer. Hardy annual. $1 \frac{1 / 2}{2}$ feet.

Chabaud's Giant Double. This splendid Chabaud's Giant Double. variety of superb size and finest colors, flowers freely the first year, and if the soil is what it should be, will continue to bear indefinitely. Mixed. Pkt. 25 cts., oz. $\mathbf{\$ 3 . 5 0}$.

\section{CARDINAL CLIMBER}

We consider this one of the most beautiful and brilliant of annual vines. It is a strong and rapid grower, attaining a height of 20 feet or more, with beautiful fern-like foliage, literally covered with a blaze of fiery cardinal red flowers from mid-summer 'til frost. It delights in a warm sunny situation, and a good soil. Germination is madé more certain by cutting a small notch in each seed. Hardy annual. Pkt. 10 cts., oz. $\$ 2.00$.

\section{CASTOR BEAN (See Ricinus.)}

\section{CELOSIA (See Cockscomb.)}

\section{CENTAUREA CANDIDISSIMA}

Dusty Miller. A silver leaved plant whose

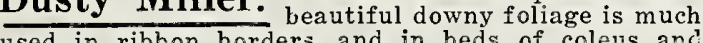
used in ribbon borders, and in beds of coleus anc geraniums. Tender perennial. 1 foot. Pkt. 5 cts., oz. 60 cts.

\section{CENTAUREA CYANUS \\ (See Corn Flower.) \\ CHINESE WOOL FLOWER \\ (See Cockscomb.) \\ CLARKIA}

One of the prettiest and showiest of hardy annuals. Blooms freely and will grow in any soil. 2 feet. Mixed. Pkt. 5 cts., oz. 60 cts.

\section{COBOEA SCANDENS}

A magnificent climber, growing thirty feet and upwards, if planted in a rich, sunny situation. The flowers are large, symmetrical bells, which, light green when first opened, turn gradually to a fine purple-lilac. To secure germination of the seed, plant them edgewise in boxes of moist earth, giving no water until they have sprouted. Tender perennial. Pkt. 10 cts., oz. $\$ 1.00$.

\section{COLEUS}

Plants with richly colored foliage, valuable for pot culture, and indispensable for groups on lawns and in ribbon gardening. Our stock of this seed is a mixture of superb hybrid varieties, and will produce foliage of the most beautiful marks and stainings. 2 feet. Mixed. Pkt. 25 cts., oz. $\$ 9.00$.

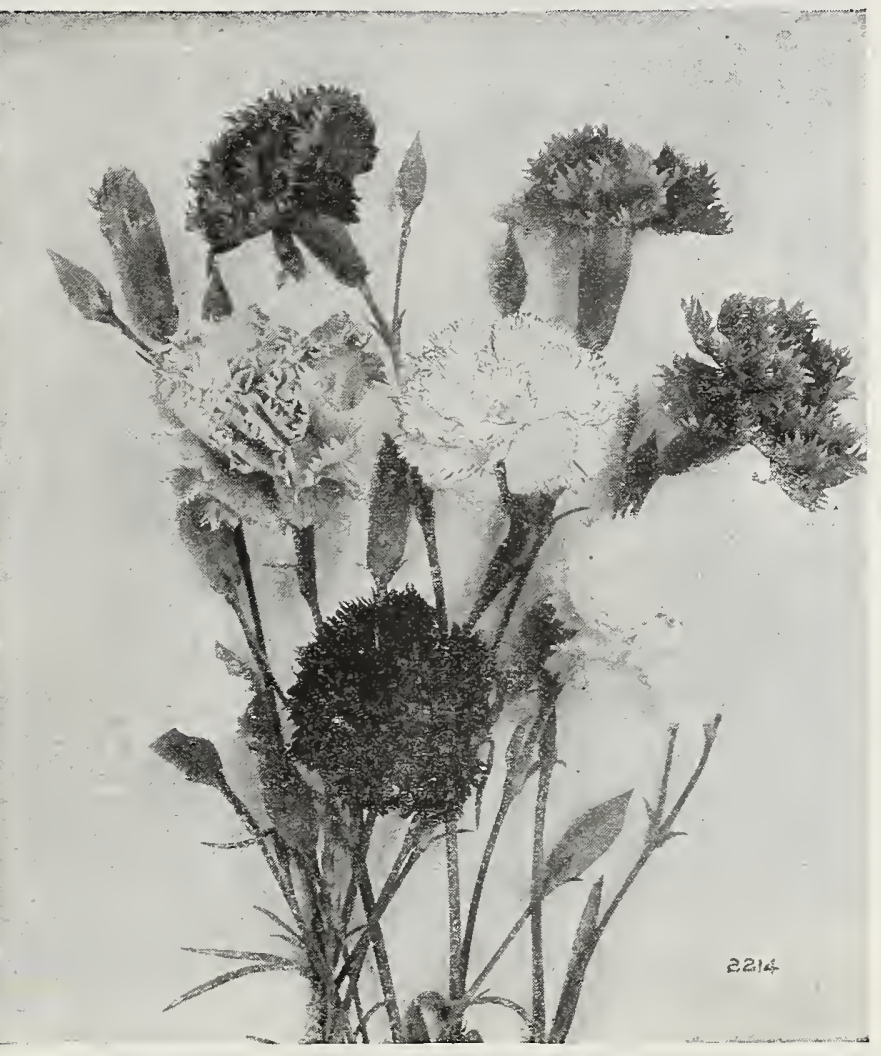

Chabaud's Everblooming Carnation

\section{COCKSCOMB}

Popular annuals of easy culture. The beautifully formed, highly colored flowers are very attractive and effective.

Glasgow Prize. Immense showy, dark crimson comb. Feathered A handsome foliage plant producing large, showy, graceful, feathery blooms. 2 to 3 feet. Pkt. 10 cts., oz. $\$ 1.00$.

Chinese Wool Flower. A unique form of feathbright red color, forming large globular heads like balls of wool. Pkt. 10 cts., oz. $\$ 2.50$.

\section{COLUMBINE}

An old flower whose curious form and exquisite colorings will always ensure its popularity. With a constitution like that of the roadside weeds, it is very serviceable for grouping in corners or for naturalizing purposes, etc. Hardy perennial. 2 feet. Mixed. Pkt. 10 cts., oz. \$1.00.

\section{COLLINSIA}

This favorite flower is also known as "Ragged-Robin", "Bachelor's Button", etc. They are of easy culture and produce an abundance of bright colored and beautifully formed flowers, and are splendid for cutting. Our strain of seed embraces everything desired in color and form. Hardy annual. $1 \frac{112}{2}$ feet. Mixed. Pht. 5 cts., oz. 60 cts. 


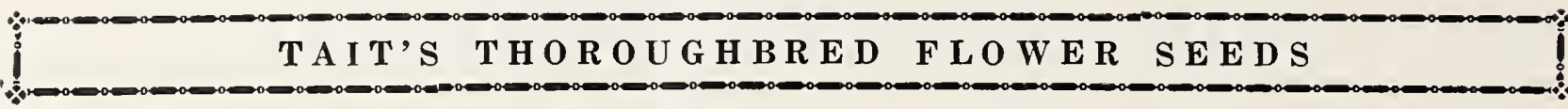

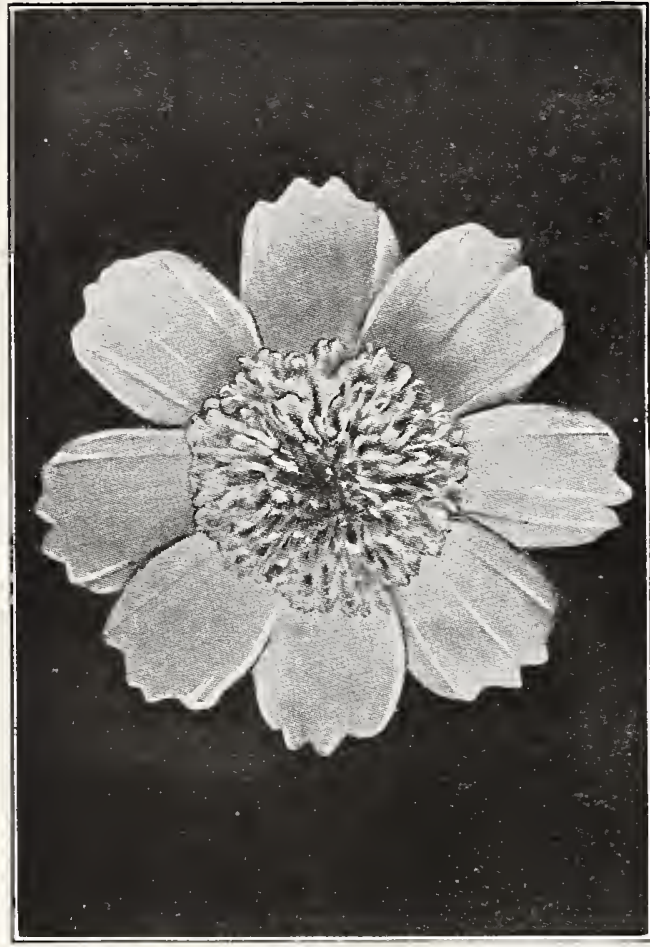

Double Crested Cosmos.
CONVOLVULUS (See Morning Glory.)

\section{COREOPSIS}

For borders there is nothing brighter or more reliable than the Coreopsis. The plant is covered from early summer until frost with beautiful flowers, each bloom being 3 or 4 inches across.

Lanceolata Grandiflora. Single golden yellow flowers of ing; ting; blooms the entire summer. Hardy perennial. Pkt. 5 cts., oz. 50 cts.

\section{CORNFLOWER}

None of the other Centaureas compare with this old-fashioned favorite known and loved under so many names- "Ragged-Robin". "Blue Bottle", "Bachelor's Button", "Bluets", etc. Although quite as hardy as any wild flower, they are exquisite in form and color and make particularly effective table decorations. The blue is one of the finest shades of that color ever seen in nature. Hardy annual. 1 $1 \frac{1}{2}$ feet. Mixed. Pkt. 5 cts., oz. 60 cts.

\section{COSMOS}

Few flowers have orown more in popularity in late years than the Cosmos. A strong tall growing annual, and for cutting this is one of the finest flowers grown. Hardy annual. 5 to 6 feet.

\section{Extra Early Mammoth Flowering Cosmos}

Started early, in the house or frame, this type will produce flowers a month earlier than Giant Perfection. Offered in pink, red, and white, or all colors mixed. Pkt. 5 cts., oz. 60 cts.

Giant Perfection. Large flowers on long stems. For cutting I. this is one of the finest flowers grown. Pink, red and white, or all colors mixed. Pkt. 5 cts., oz. 60 cts.
Lady Lenox, Pink. Lovely shell-pink. Long stemmed Lady Lenox, Pink. flowers of immense size. Unsurpassed for garden decoration and as cut flowers. 6 to 7 feet. Pkt. 15 cts., oz. $\$ 1.00$.

Lady Lenox, White. A fine white selection from the Double Crested. Beautiful varieties of recent introcrested, having double centers, with a row of guard petals around the base. Colors are pink, crimson, white and mixed Pkt. 15 ets., 3 pkts., one of each color, 40 ets.

\section{CYPRESS VINE}

One of the most popular of all summer climbers. The star-shaped flowers are small and thickly set in beautiful dark green foliage of fern-like appearance. Tender annual. 15 feet.

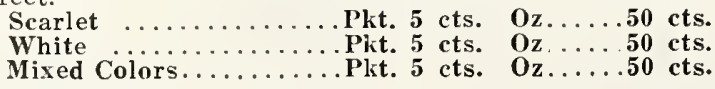

\section{DAHLIA}

Contrary to general belief, dahlias will bloom the first year, if the seed is sown early. The strain we offer is finely selected, and will show very few single flowers. For ten cents we will supply enough seeds to make roots worth several dollars. Half-hardy perennial. 3 to 6 feet. Finest mixed double. Plit. 10 cts., oz. $\$ 2.00$

DAHLIA ROOTS (See Pages 89, 90, 91.)

\section{DAISY (Bellis)}

The double English Daisy is adapted for edgings, borders and low beds, and well suited for growing in pots. The flowers are very numerous, perfectly double, and of the loveliest colors. They will bloom the first season if seed is sown early. Half-hardy perennial. 6 inches.

Double English. Finest mixed. Pkt. 10 cts., oz. \$3.00.

Single Paris. Pkt. 10 cts., oz. $\$ 1.00$.

\section{DELPHINIUM (See Larkspur)}

\section{DIANTHUS BARBATUS (See Sweet William.)}

\section{DIANTHUS, or HARDY PINKS}

The Dianthus family contains some of our most beautiful and best loved flowers, unsurpassed for color and fragrance. They begin blooming a few weeks after sowing, and until killed by frost are literally covered with flowers all the time. 1 to 2 feet.

Chinese Double (Chinese or Indian Pink.) Easily $10 \mathrm{cts.}$, oz. $\$ 1.00$.

Diadematus (Diadem Pink.) The flowers are very radematus. double and all the petals have the outer edges beautifully fringed. Mixed. Pkt. 10 cts., oz. \$1.00.

Eastern Queen. This variety is of extraordinary who love pinks. Pkt. 10 cts., oz. $\$ 1.00$. 
GEO.TAIT \& SONS, INC., NORFOLK, VA.

Heddewiggi. (Japan Pinks.) The flowers are large Heddewiog and charmingly marked with stripes, staining and rings. Mixed. Pkt. 10 cts., oz. $\$ 1.00$.

Laciniatus. Extra fine, very showy fringed flowers. Pkt. 10 cts., oz. $\$ 1.00$

Pheasant's Eye. A beautiful single variety with . fringed edges. Pkt. $10 \mathrm{cts.,0z.} \$ 1.00$.

\section{DIDISCUS (Blue Lace Flower)}

Coeruleus. This welcome addition to our garden anCoeruleus. nuals comes from Australia. The plants grow about 2 feet high, producing graceful subdivided foliage. The flowers, which bloom profusely from July till October, are excellent for cutting. The color is the most beautiful imaginable, exquisite pale lavender. Pkt. 15 cts., 2 pkts. 25 cts.

\section{DIMORPHOTHECA (African Daisy)}

Aurantiaca Hybrida. This very showy annual Africa. The bushy plants grow 12 to 15 inches high. The flowers, which are over $21 / 2$ inches in diameter, vary in color from the purest white through the various shades of yellow and orange to rich salmon, many being zoned with several of these colors around the black disc. They should have a dry, sunny position, and the seed may be sown in the same way as Asters or Petunias. Pkt. 15 cts., 2 pkts. 25 cts.

\section{DISH CLO'TH GOURD}

An ornamental climber with prettily shaped foliage and yellow flowers, which are borne in clusters. The seed pod is about two feet long, and when ripe has a porous lining of sponge-like texture. This, "when dried, may be easily separated from the rind, and makes an admirable dish cloth or flesh brush. It is also often converted into various fancy articles about the house. Pkt. 5 cts., oz. 60 cts.

\section{DOLICHOS LABLAB (Hyacinth Bean)}

This rapidly growing hardy annual climber produces a great amount of foliage, and is covered with spikes of peashaped blossoms, followed by ornamental seed pods. Plant the seed where the vine is to grow. 10 feet.

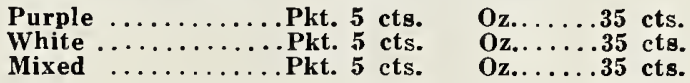

\section{DUSTY MILLER}

(See Centaurea Candidisima.)

\section{ECHINOPS (Globe Thistle)}

Ritro. These striking perennial plants, growing from 3 Ritr. to 5 feet high, are excellent for the back of the hardy border among other tall plants. The silvery thistlelike foliage is very handsome and the fine steel blue flowers can be used for cutting. Pkt. 10 cts.

\section{ESCHSCHOLTZIA (California Poppy)}

Showy plants, flowering profusely all the season. Their various shades of yellow are attractive in beds or borders. Half-hardy annuals. Mixed. 1 foot. Pkt. 5 cts., oz. 60 cts.

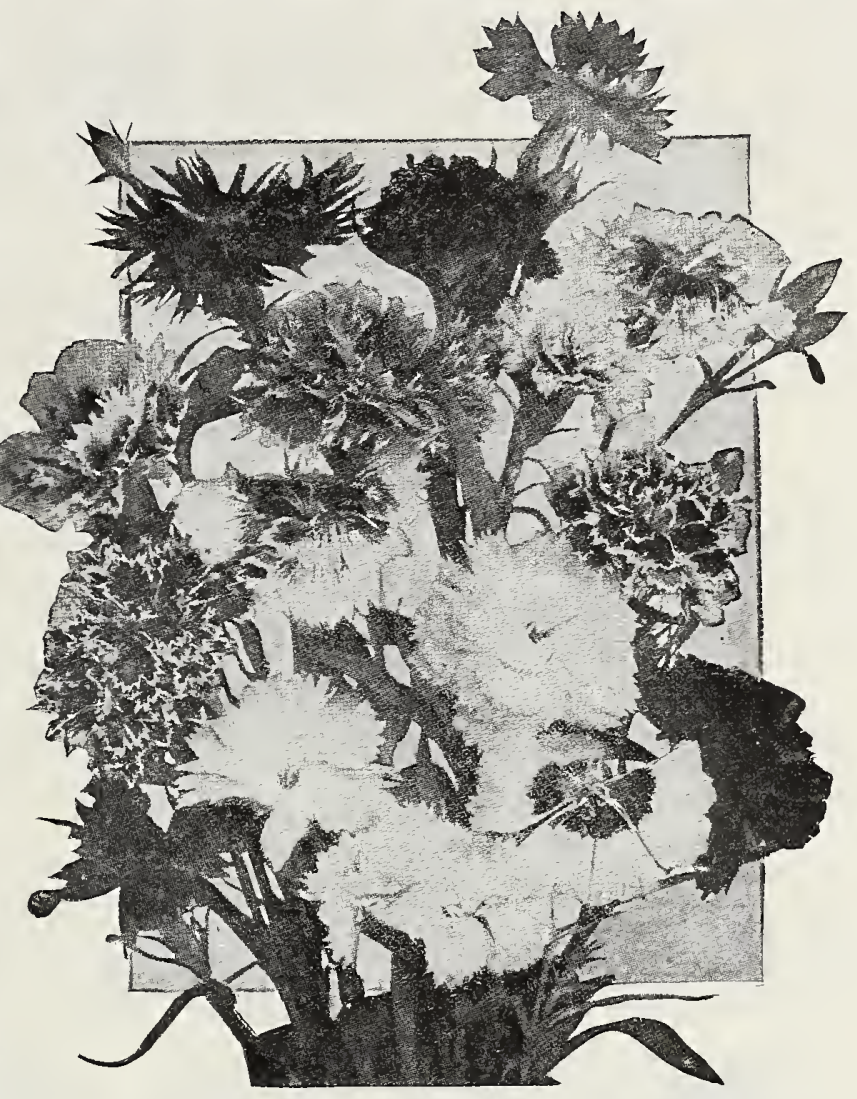

Dianthus Pinks.

\section{EUPHORBIA (Snow on the Mountain)}

Variegata. The exceedingly ornamental foliage of this aros strong growing annual makes it one of the most popular of our garden plants. The light green leaves are veined and margined with white. 2 feet. Pkt. 10 cts.

\section{EVERLASTINGS}

Acroclinium, Globe Amaranthus, Helichrysum, Cockscomb, Rhodanthe, Statice, Xeranthemum. Each of these is described under its own name.

\section{FEVERFEW (See Matricaria.)}

FLOSS FLOWER (See Ageratum.)

\section{FORGET-ME-NOT}

A favorite old border plant that succeeds best in moist situations. It comes into blossom early and the little starshaped blue flowers appeal to every heart. Hardy perennial, 6 inches. Pkt. 10 cts., oz. $\$ 1.00$.

FOUR O'CLOCK (See Mirabilis Jalapa.)

\section{FOX GLOVE}

Hardy Perennials, producing long clusters of tubulous flowers. Splendid for shrubberies, shady places and borders. Height 4 to 5 feet. Pkt. 10 cts., oz. 60 cts.

Remember we deliver free at catalogue prices-except where noted. Write for special prices in large quantitiee. 


\section{GAILLARDIA (Blanket Flower)}

Very showy annuals, bearing many brilliantly colored flowers, and well adapted for garden decoration and cutting. $1 \frac{1}{2}$ feet.

Finest Double Mixed............. 10 cts. Oz.....\$1.00

Finest Single Mixed............Pkt. 10 cts. Oz.....\$1.00

\section{GERANIUM}

Geraniums may be readily raised from seed by sowing in boxes of fine earth and placing in a gentle heat. A packet of seed will furnish a large number of plants, and occasionally one or more of the seedlings will develop an absolutely new sort, all new Geraniums being thus produced. Half-hardy perennial. $1 \frac{1 / 2}{2}$ feet,

Zonale Mixed................Pkt. 10 ets. $\quad$ Oz.....\$2.50

\section{GILIA}

Pretty dwarf plants, very fine for massing and rock work. The flowers are small, but charming in the general color effect. Hardy annual. 1 foot. Mixed. Pkt. 5 cts., oz. 60 cts.

\section{GODETIA}

A profuse bloomer, excellent for borders. The flowers are large and remarkable for their richness and variety of coloring. Hardy annual. 1 foot. Mixed. Pkt. 5 cts., oz. 60 cts.

\section{GYPSOPHILA}

Better known as "Baby's Breath," and can be had in either annual or perennial varieties. It is most easily grown, producing quantities of graceful and delicate flowers in pink and white. Height 2 feet.

White Grandiflora (Annual)......Pkt. 10 cts.

Pink Grandifiora (Annual)........Pkt. 10 cts.

Oz.....\$ .75

White Paniculata (Perennial)....Pkt. 10 cts.

Oz....... $\quad .75$

Oz....... 1.00

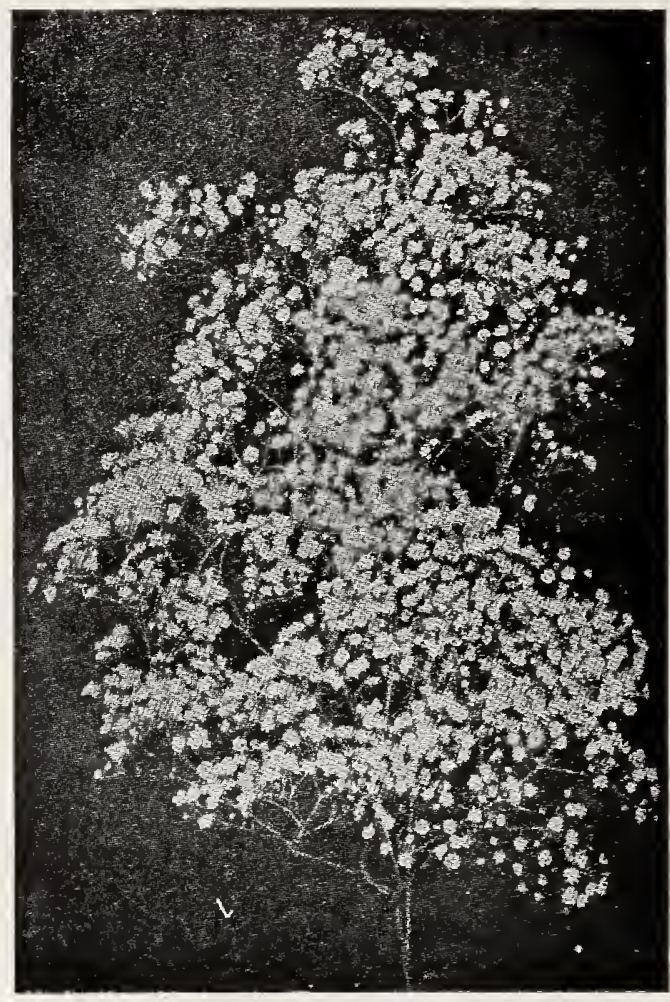

Gypsophila (Baby's Breath).

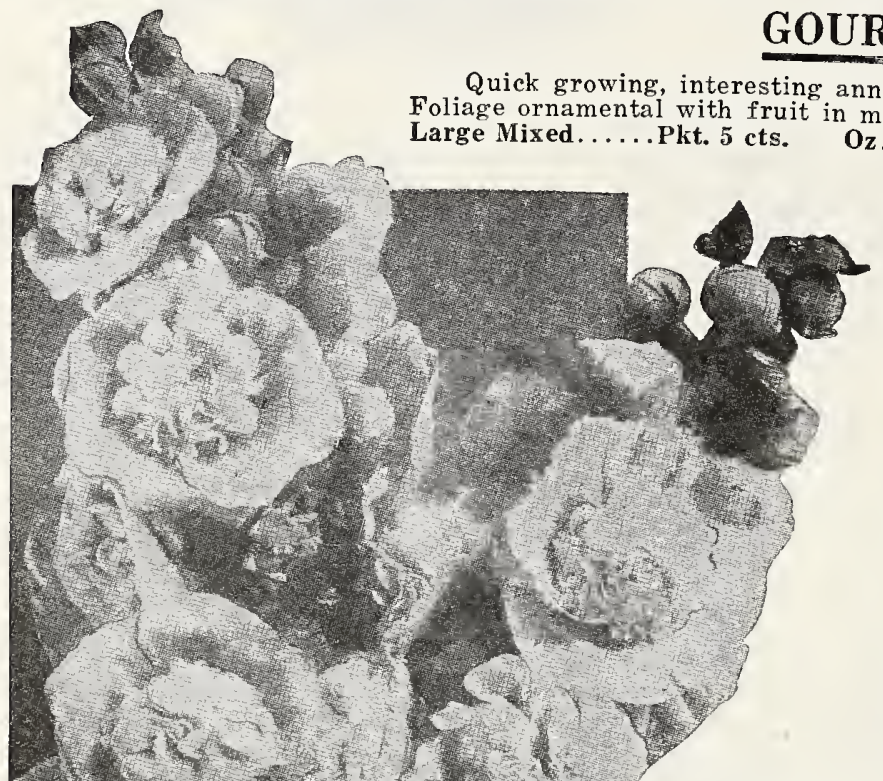
be gathered when coming into bloom and suspended with head downward in a cool place. Hardy annual, 2 to 3 feet. Fine mixed. Pkt. $10 \mathrm{cts} ., 0 z$. 60 cts.

\section{HELIOTROPE}

This half-hardy perennial is adapted to both bedding and house culture, requiring little attention. Seeds started indoors early in the spring will make fine plants for summer blooming. The blossoms are delicately tinted, and very fragrant. 2 feet. Choice mixed. Pkt. 10 cts., oz. \$2.50.

\section{HOLLYHOCK}

The beautiful color effects, and the dignified, stately appearance render these popular perennial plants indispensable in the old fashioned garden, and they are without an equal as a back ground for other flowers or for planting among shrubbery. If sown in July or August, the plants will bloom the following spring. 5 to 7 feet.

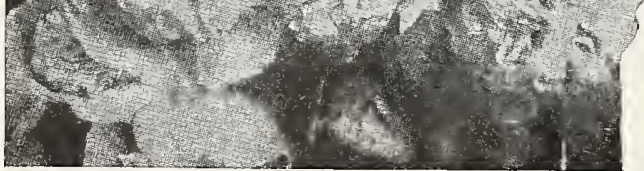

Double Hollyhocks.

Charter's Superb Double. Our seed has been saved from the

sure to produce satisfactory results finest double flowers only and

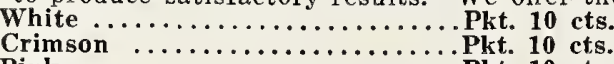
Pink ..................... 10 ets. Yellow ........................ 10 cts. Extra Choice Mixed ................ 10 ctst.
Oz ......\$2.50

$0 z \ldots \ldots 2.50$

z ...... 2.50

$\mathrm{Oz} \ldots \ldots 2.50$

$\mathrm{Oz} \ldots \ldots 2.50$

Remember we deliver free at catalogue prices-except where noted. Write for special prices in large quantities. 


\section{HUMULUS, OR JAPANESE HOP}

A rapid summer climber resembling the common Hop, but the foliage is more luxuriant in appearance, while the mixture of white, light green, and dark green makes it strikingly ornamental. Heat, drought, and insects do not trouble it. It is one of the best plants for covering verandas, trellises, etc. Hardy annual. 15 feet. Pkt. 10 cts., oz. $\$ 1.00$.

\section{HUNNEMANNIA}

The flowers of this splendid variety of Poppy are much like the finest Eschscholtzias. It blooms about ten weeks after sowing, and produces large golden yellow flowers until late fall. 2 feet. Pkt. 5 cts., oz. 60 cts.

\section{HYACINTH BEAN (See Dolichos Lablab.)}

\section{ICE PLANT}

A pretty little trailing plant, the leaves and stems of which are covered with a remarkable crystalline substance much resembling ice. Half-hardy annual. Pkt. 5 cts., oz. 60 ets.

IPOMOEA CARDINALIS (See CardinalClimber)

IPOMOEA QUAMOCLIT (See Cypress Vine.)

IPOMOEA MEXICANA (See Moon Flower.)

IPOMOEA PURPUREA (See Morning Glory)

JOSEPH'S COA'T (See Amaranthus Tricolor)

\section{KOCHIA}

(Summer Cypress, or Mexican Firebush.)

A rapid-growing plant with foliage somewhat resembling that of the Cypress Vine. The feathery, light green foliage turns to a fiery red in the autumn. Hardy annual. 2 feet. Pkt. 5 cts., oz. 50 cts.

\section{LANTANA}

A well-known shrub, splendid for bedding, as it is constantly in full bloom. The flower stem is crowned with a large truss of verbena-like flowers of infinitely varied hues. Tender perennial. 2 feet. Mixed. Pkt. 5 cts., oz. 60 cts.

\section{LARKSPUR}

The colors of the carkspur are extremely beautiful, and in mixed borders its profuse masses of purple, white and pink show splendidly. It is best to sow the seed in the fall or very early spring. 3 feet.

Stock Flowered Double Mixed. Pkt. 5 cts., oz.

\section{PERENNIAL LARKSPUR or DELPHINIUM}

The perennial varieties of delphiniums are usually taller than the annual sorts and the flowers much larger, but do not bloom until the second season.

Gold Medal Hybrids. This is the finest strain of mixed Gold Medal Hybrids. hybrids ever offered. The plants are of strong vigorous habit, with large flowers on spikes from 12 to 15 inches long. Pkt. 15 cts.

Delphinium Belladonna. (Everblooming Hardy Larkspur) Dellad is the freest and most continuous blooming hardy Larkspur. The color is clear turquois. Plst. 25 cts.

Delphinium Chinensis.

(Blue Butterfly)-A distinct and neat variety growing 18 inches high and producing freely spikes of large dark blue blossoms. Pkt. 25 cts.

\section{LATHYRUS}

Few people know the usefulness of the Everlasting or Hardy Sweet Pea, but it is one of the best vines for certain urposes, being a hardy perennial of great vigor. Old fences, sightly banks or rocks can be quickly hidden, and the lways abundant flowers are good for cutting. 8 feet. Mixed. kt. 5 cts., oz. 60 ets.

\section{LAVATERA}

For massing in large beds this is excellent. The colors are pure white and delicate tints of rose and red. Half-hardy nnual. 3 feet. Pkt. 5 cts., oz. 60 cts.

\section{LOBELIA}

Neat, pretty plants of profuse bloom and color, very valNor edging as well as for hanging baskets and vases. alf-hardy annual. 6 inches. Pkt. $10 \mathrm{cts}$., oz. $\$ 2.50$.

\section{LOVE-IN-A-MIST (See Nigella.) \\ LUPINUS}

Splendid, free-flowering plants, with long, graceful spikes ( Hardy annual. 2 feet. Mixed. Pkt. 5 cts., 60 cts.

\section{LYCHNIS}

The flowers of this highly ornamental plant are very The and finely colored. It is of easy culture and should be every garden. Hardy perennial. 2 feet. Mixed. Pkt. 5 s., oz. 60 cts.

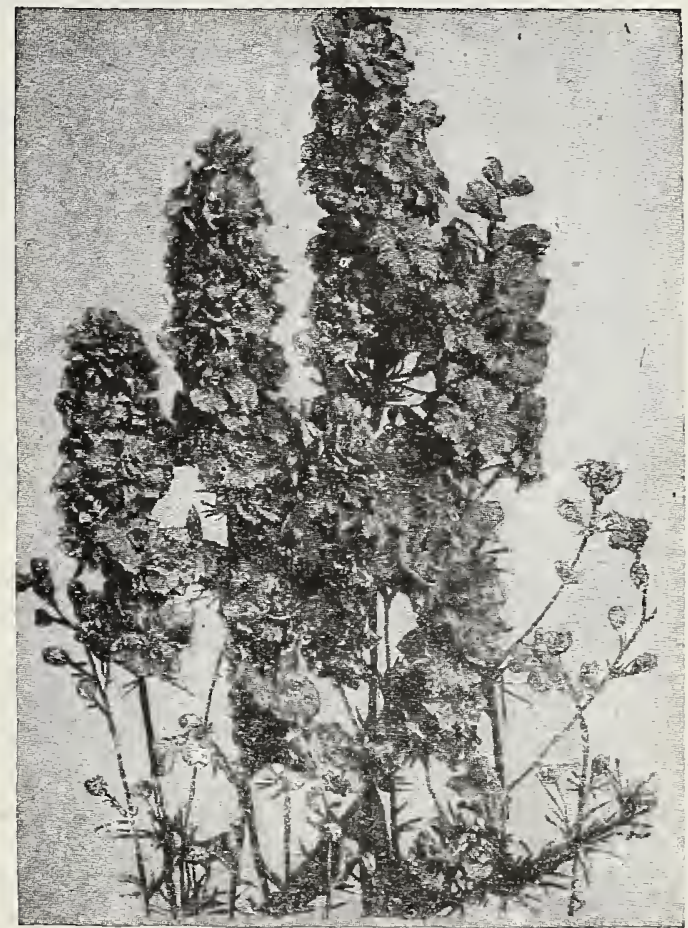

Stock Flowered Larkspur.

Remember we deliver free at catalogue prices-except where noted. Write for special prices in large quantities. 
An old garden favorite, prized for its numerous and showy flowers. It is excellent for planting in large beds, and will thrive in any good soil.

\section{DOUBLE AFRICAN MARIGOLD}

Orange Prince, Large perfect double quilled flowers of a rich deep, golden $\$ 1.50$.

Lemon Queen. Identical with the above, exLemon Queen. cept in color, which is a soft lemon yellow. Pkt. 15 cts., oz. $\$ 1.50$.

Finest Mixed. A mixture of all the various

\section{DWARF FRENCH MARIGOLD}

The old variety, with rich, velvety and beautifully striped flowers. Half-hardy annual. 2 feet. Mixed colors. Pkt, 10 cts., oz. $\$ 1.00$.

\section{MATRICARIA}

The double white Feverfew, sometimes called Bachelor Button, very useful as an edging to large beds as it succeeds in any garden soil. Hardy annual. 2 feet. Finest double. Pkt. 5 cts., oz. $60 \mathrm{cts}$.

\section{MAURANDIA}

This magnificent tender climbing perennial flowers from seed the first season. It grows rapidly, blooms profusely all the season, and the fine, delicate foliage is much prettier than Smilax. 10 feet. Mixed. Pkt. 10 cts., oz. $\$ 1.50$.

\section{MIGNONETTE}

Well known, fragrant favorites. A succession of blooms both summer and winter may be had by repeated sowings, and in order to have large spikes, the plants should be thinned enough to prevent spindling stems.

Machet of robust, stocky growth, producing in great Irache abundance large conical heads of deliciously fragrant flowers. 1 foot. Pkt. 10 cts., oz. 75 cts.

\section{MIRABILIS JALAPA \\ MIRABILIS JALAPA}

$$
\text { to } 3 \text { feet. Pkt. } 15 \text { cts., oz. }
$$
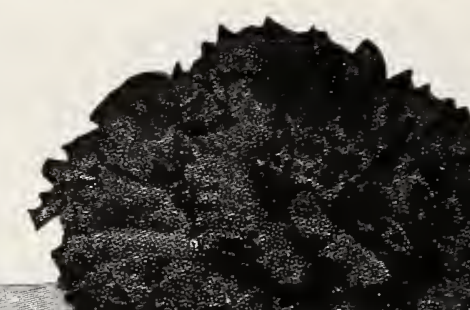

The Four o'Clock has long been a favorite and is, when properly treated, an extremely ornamental plant. The flower is shaped like that of the Morning Glory, produced in clusters and blooms in the afternoon. If the plants are set two or three feet apart in a sunny place they will not fail to produce a very fine effect. Half-hardy perennial. 2 feet. Mixed. Pkt. 5 cts., oz. 60 cts.

\section{MONKEY FLOWER}

The dainty little Mimulus is one of the best smail plants we have, the flowers being as unique as they are beautiful with their brilliant spots and blotchings. If the seeds are sown reasonably early, the plant will bloom the first summer. Half-hardy perennial. 1 foot. Mixed. Pkt. 10 cts., oz. \$1.25.

\section{MOON VINE}

Sky-Blue Moon Flower. The vine of this variety grows from 15 to 18 feet, producing gorgeous flowers in shape Pkt 10 ctse like the Morning Glory of a lovely sky-blue with markings of rose. Tender anWhite. A wonderful vine which, if set out in rich ground and given support, will grow forty to fifty feet in a single White. season. The flowers, which are several inches in diameter, are white and have a rich Jessamine odor. It blooms

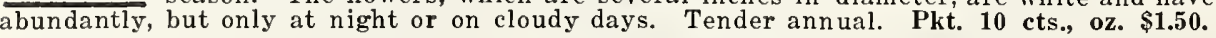

\section{MORNING GLORY}

All members of this family are characterized by such extraordinary beauty of color that it is small wonder that the common name for them is "Morning Glory." Although the flower is so delicate in texture that it withers before the first touch of sunshine, the vine is the hardiest of our entire list of climbers, growing rapidly in a soil of any character. Unsightly objects may be thus transformed in a few weeks, but the flowers are, of course, useless for cutting. Hardy annual. 15 to 20 feet.

Japanese Imperial. Those who have never seen the Japanese Morning Glory can form no idea of its indescribable but are of infinitely varied colorings and most exquisite form, many having fringed and intricately frilled edges. Pkt. 10 cts., oz. $\$ 1.00$. Major. A vigorous climber, familiar to every one. It is a very rapid grower, making a wonderfully gay display in the 


\section{TAIT'S SUPERB NASTURTIUMS}

No other hardy annual will produce such a lavish profusion of flowers for so long a period with the same outlay of time and labor. The tall varieties make a very effective display when trained on fences or trellises, and the dwarf sorts are fine for edging and massing. The seed we offer is a selected strain and mixed in proper proportion so that our customers may be assured of having all the effective shades of scarlet, crimson, rose, pink, orange, yellow, white, etc. The maximum of bloom is produced on thin soils. In soils too rich, leaves predominate and the plants are apt to rot off in wet weather, especially if standing too close.

\section{DWARF OR TOM THUMB}

Of neat compact growth and attractive. foliage. Blooms profusely the whole season. Hardy annual. 1 foot. Chameleon. Beautiful, mottled and spotted flowers on the same plant. Pkt. 10 cts., 0 z. 20 cts., 1/4 lb. 60 cts. Cloth of Gold. Yellow foliage with scarlet flowers. Pkt. 10 cts., oz. 20 cts., 1/4 lb. 60 cts. Crimson Bedder. Rich velvety crimson. Pkt. 10 cts., oz. 20 cts., $1 / 4$ lb. 60 cts. Empress. Crimson, with dark foliage. Pkt. 10 cts., oz. 20 cts., $1 / 4$ lb. 60 cts. Gem. Bright yellow with scarlet blossoms. Pkt. 10 cts., oz. 20 cts., 1/4 lb. 60 cts. Moonlight. Creamy white. Pkt. 10 cts., oz. 20 cts., $1 / 4$ lb. 60 cts. Vesuvius. Salmon rose, dark foliage. Pkt. 10 cts., oz. 20 cts., $1 / 41$ b. 60 cts. Mixed. Pkt. 10 cts., oz. 15 cts., $1 / 4$ lb. 50 cts., 1 lb. $\$ 1.75$.

\section{TALL OR CLIMBING VARIETIES}

Besides their garden use, this is a favorite house plant for winter blooming. The flowers are like those of the dwarf variety, but are usually much larger. Hardy annual. 8 to 10 feet.

Beauty. Dark crimson. Pkt. 10 cts., oz. 20 cts., 1/4 lb. 60 cts. Chameleon. Beautiful, mottled and spotted flowers on the Lady Bird Orange yellow spotted with dark crimson. Pkt.

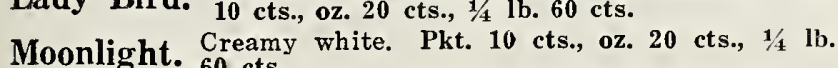
Sweetheart Lovely bright rose. Pkt. 10 cts., oz. 20 cts., Sweetheart. 1/4 lb. 60 cts.

Mixed. Pkt. 10 cts., oz. 15 cts., 1/4 lb. 40 cts., 1 lb. $\$ 1.50$.

\section{NEMOPHILLA}

Of close, compact habit of growth, and in shady places a steady bloomer. The flowers are of beautiful colors, varying greatly in shades, but being very small, show to perfection only when closely massed. Hardy annual. 6 inches. Mixed. Pkt. 5 cts., oz. 60 cts.

\section{NICOTIANA}

Silvestris Many varieties of tobacco are very ornamental, Silvestris. Many varieties of tobacco are very ornamental pyramidal form to a height of four feet, with foliage of the most vivid green; the flower stem is tall and bears in a loose head clusters of long, drooping flowers, deliciously fragrant and of snowy whiteness. Tender perennial. Pkt. 10 cts., oz. $\$ 1.00$.

\section{NIGELLA}

("Love in a Mist" or "Devil in a Bush")

An interesting plant, with very finely divided foliage and curious flowers. The seed pod is enclosed in a close, delicate net work of leaves which has suggested the names by which it is commonly known. Hardy annual. $1 \frac{1 / 2}{2}$ to 2 feet. Pkt. 5 cts.

\section{PEONY}

Easily grown, hardy perennial that should be in every garden, and none are more prized than Peonies with their large and handsome blooms. 2 feet. Mixed. Pkt, 10 cts., oz. $\$ 1.00$.

\section{PEONY ROOTS}

Nasturtium

We can also supply Peony Roots in the fall and spring. (See pages 91, 92.)

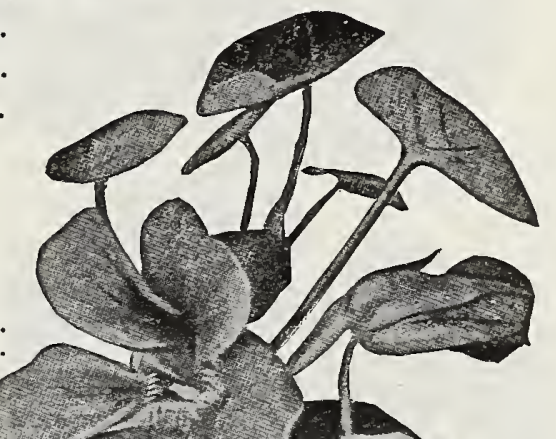




\section{Tait's Unrivalled Pansies}

The Pansy is one of our specialties and a plant we all delight to grow in plentiful supply. If the seed is sown in August or September, and a little protection given during the winter, they will bloom abundantly the following spring. Pansies thrive in a cool moist soil and a situation that protects them from cutting winds as well as the mid-day suns. Spring-sown seed should not be permitted to bloom until cold weather, and the buds should be picked off, allowing the plant to make a compact and bushy growth, insuring large and brilliant flowers throughout the fall. Do not allow faded blossoms to remain on the plants. The higher-priced sorts produce the largest flowers and the most brilliant colors. This should be borne in mind when ordering. The seed offered by us is grown by three of the greatest specialists in the world, and Pansy lovers can get no finer strain.

\section{SHOW MIXTURES OF PANSIES}

Fine Large Flowering. Of excellent stock, fine color, and Finest Stained. This mixture is from magnificent varieties and priced named pansies. Pkt. 15 cts., oz. $\$ 3.50$.

Masterpiece. Enormous flowers having ruffled wavy petals, showpredominate. Pkt. 25 cts., oz. $\$ 10.00$.

Tait's Thoroughbred Giant Exhibition. For size and ers, variety and brilliancy of coloring and markings, nothing approaches this strain. The seed is from only exhibition flowers. To gardeners who have grown only ordinary pansies these giant flowers will be a revelation. Pkt. 25 cts., oz. $\$ 10.00$.

\section{PANSIES IN SEPARATE COLORS}

Adonis. A beautiful light blue pansy. Pkt. 15 cts.

Azure Blue. Velvety, violet blue. Pkt. 15 cts.

Faust Almost jet black and the most striking of all dark pansies. Faust Pkt. 15 cts.

Fire King. Golden, upper petals purple. Pkt. 15 cts.

General Foch. White, each petal having a violet blotch. Pkt. 15 General Pershing. Cornflower blue. Very fine. Pkt. 15 cts. Golden Queen. Pure yellow. Also called Yellow Gem. Pkt. 15 Lord Beaconsfield. Large purple violet, top petals white. A Lord Beaconsfield. splendid pansy. Pkt. 15 cts.

President McKinley, Dark, blotched petals, margined yellow. Pkt. 15 cts.

Royal Purple. Purplish violet, very fine, large flowers. Pkt. 15

\section{PENSTEMON}

Beautiful fine flowering perennials with long graceful spikes of richly colored Glozinia-like blossoms, very hardy; fine for beds and borders or rock gardens. 2 feet. Mixed. Pkt. 15 cts., oz. \$4.00.

Giant Exhibition Pansies.
Remember we deliver free at catalogue prices-except where noted. Write for special prices in large quantities. 


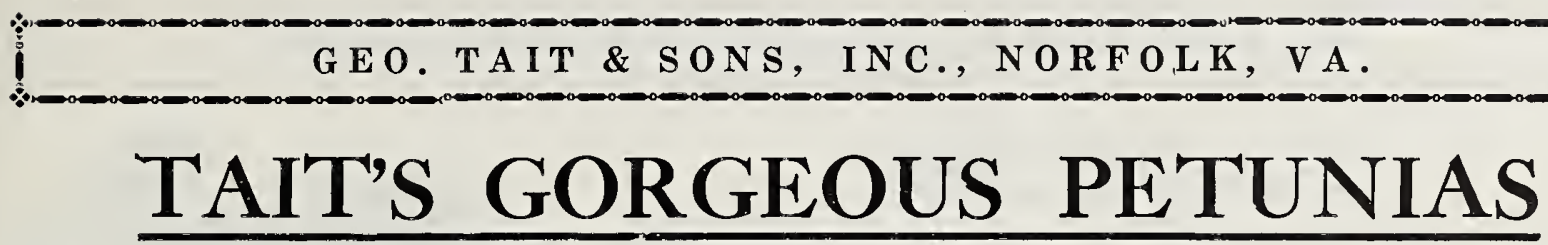

There is no bedding plant of easier culture than the Petunia. Once started, Petunias grow almost as strong as weeds, and furnish a glorious succession of bloom from early summer until frost. Seed of the Double and Fringed varieties is made expensive by the great amount of labor involved in hand fertilization, and it is well to handle seed and tiny seedlings with some care. As the seed is as fine as dust, it is advisable to sow in boxes in the house, transplanting when large enough. We have no better plants than the Petunia for beds and masses, borders, window boxes and baskets. The seeds we offer are from the most carefully selected strains, saved at great expense, and will produce fine and handsome flowers. Average height 1 foot. Hardy annual.

\section{SINGLE FLOWERED PETUNIAS}

Rosy Morn. A beautiful and dainty variety for window or porch boxes. Rose colored flowers with a white throat. Pkt. Single Mixed Bedding. A superb mixture of the purest single Single Large Flowered Fringed. Flowers of very large fringed. Our mixture contains a remarkable variety of colors and is very popular. Pkt. 35 cts.

Ruffled Giants. With ruffed and fluted edges, these immense

\section{BALCONY PETUNIAS}

For window or porch boxes, terraces, or in rock work, the Balcony Petunia will supply an abundance of color, and the plants are literally covered with bloom throughout the summer.

Balcony White. Magnificent pure white. Balcony 15 cts.,2 pkts. 25 cts. Balcony Rose. Beautiful bright rose, 15 cts., 2 pkts. 25 cts.

Balcony Red. Dark Red. Pkt. 15 cts., 2

Balcony Blue. Dark purple blue flowers Dorne above rich green

\section{DOUBLE FLOWERED}

\section{PETUNIAS}

\section{Double Large Flowered Fringed}

These large, fragrant, elegantly formed flowers are beautiful for either house, garden or conservatory. Our seed will produce a large percentage of double flowers of the largest fringed types in a great variety of colors and tints. Pkt. 35 ets.

\section{Double Striped and Blotched.}

The flowers of these beautiful double Petunias are striped and blotched in a great variety of colors. Pkt. 25 cts.

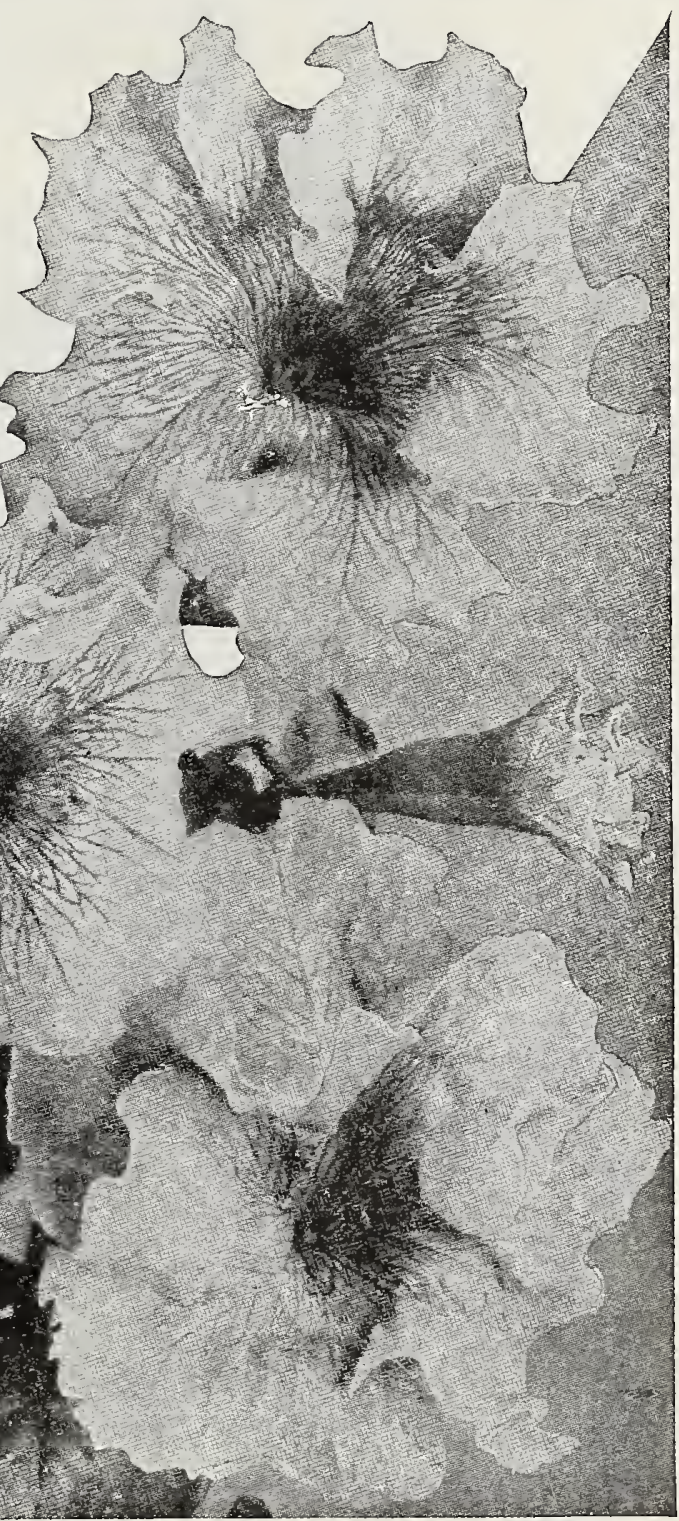

Ruffled Giant Petunias.

Remember we deliver free at catalogue prices-except where noted. Write for special prices in large quantities. 


\section{PHLOX DRUMMONDI}

For beds and massing, nothing can surpass these beautiful annuals. They are of easy culture, succeeding in all sunny positions, beginning to bloom in early summer, and continuing until autumn. Height $1 \frac{1 / 2}{2}$ feet.

Scarlet $\ldots \ldots \ldots \ldots \ldots \ldots \ldots \ldots \ldots \ldots$ Pkt. 10 cts. Oz....\$1.75

Pink $\ldots \ldots \ldots \ldots \ldots \ldots \ldots \ldots \ldots \ldots \ldots$. 10 cts. Oz...... 1.75

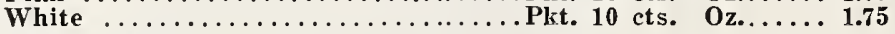

Large Flowering Mixed. Pkt. 10 cts., oz. \$1.25.

Starred and Fringed. The flowers of these beautiful varieties are Starred and Fringed. star-shaped or fringed, both types being charming novelties to those unfamiliar with them. Pkt. 10 cts., oz. \$1.75.

\section{HARDY PERENNIAL PHLOX}

This variety is a hardy herbaceous perennial, and quite distinct from the annual Phlox Drummondi. It is very easy to grow, and bears large heads of beautifnl colored flowers. Height 2 to 4 feet. Mixed colors. Pkt. 15 cts.

\section{POPPY}

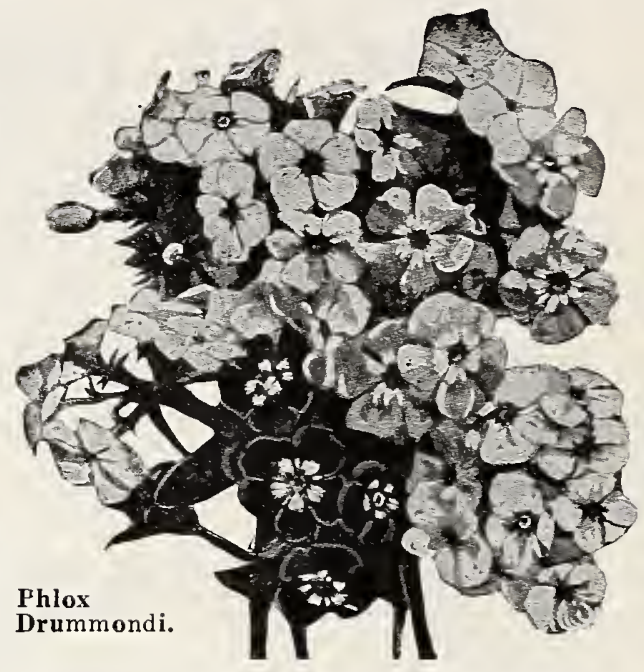

If sown early in spring. Poppies may be brought into bloom before tulips have hardly finished flowering. Few flowers have the same grace of stem, airiness of poise and delicacy of tissue. A sandy loam suits them best, and as they do not

\section{B rit t's Oriental.}

A gorgeous double pink flower, easily grown from seed. Pkt. 10 cts., oz. $\$ 1.00$.

Danebrog. Large handvariety, some single variety, scarlet with large white splotch on each petal. Pkt. 10 cts., oz. \$1.00.

Shirley. This is the fapoppy and the loveliest flower of its type. The flowers are immense, petals fluted and crinkled in the sun-light appear like crumpled satin, and the colors are of indescribable beauty and variety. While no other poppy is so good for cutting it is at the same time among the best for bedding. Pkt. 5 cts., oz. 75 cts.

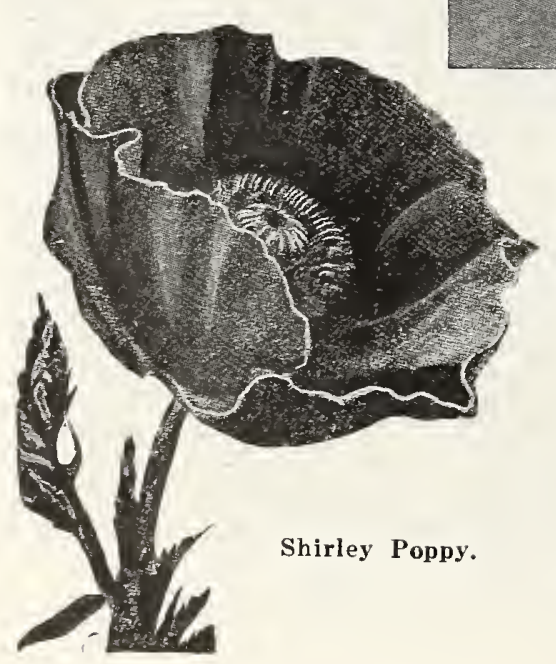

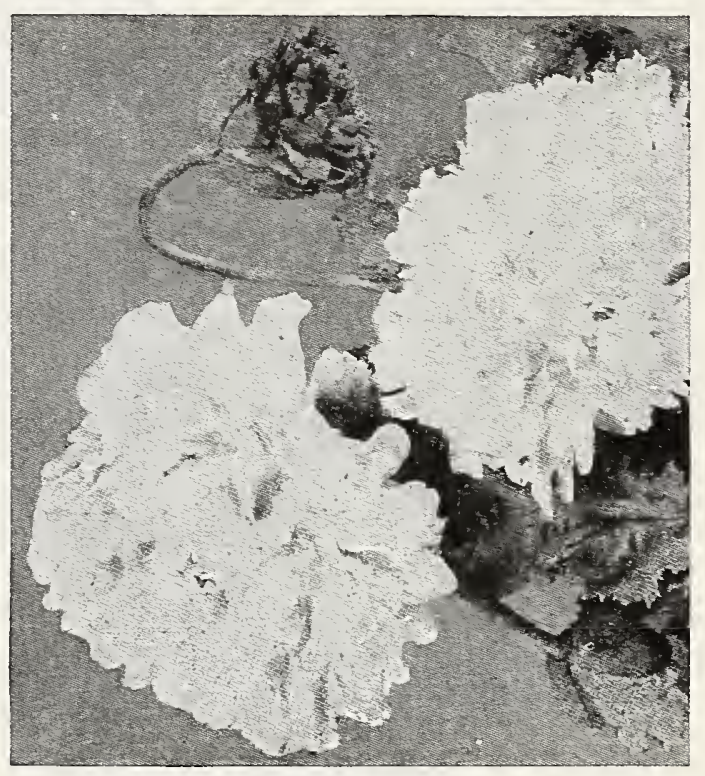

Carnation Poppy. stand transplanting, they should be sown where the plants are to bloom. Sow thinly on top of finely prepared soil and merely press seeds in firmly instead of covering the soil. Hardy annual. $2 \frac{1 / 2}{2}$ feet.

Carnation F low e r e d. Extremely double and daintily fringed Pkt. 10 cts., oz. $\$ 1.00$.

Peony Flowered. Immense Phowy, double globular flowers resembling double peonies. Pkt. 10 cts., oz. $\$ 1.00$.

Ranunculus - Flowered.

A beautiful race of poppies with bright double flowers of perfect form. Pkt. 10 cts., oz. $\$ 1.00$.

\section{PORTULACA}

Brilliant little annual plants which bloom profusely all summer, and although they do well most anywhere, hot suns and a light sandy soil suit it best. Their richly colored flowers make an effective brilliant display when planted in large beds and masses. Hardy annual. 6 inches.

Double Rose Flowered Portulaca. Our strain produces a large perbloom being a perfect rose in miniature. We have centage of double flowers, each in our mixture. Pkt. 10 cts., oz. $\$ 2.50$.

Single Mixed. This is an extra fine strain and has very large blossoms and splendid colors. Pkt. 10 cts., oz. $\$ 1.00$.

\section{PYRETHRUM}

Beautiful hardy perennials with large showy flowers and cut foliage. The Golden Feather, which we offer, is the well known variety used for carpet bedding, edging, and borders. Height 5 inches. Pkt. 10 cts., oz. 60 cts.

\section{RHODANTHE}

Delicate looking everlasting flowers of great beaty. Much prized for winter bouquets. Half-hardy annual. 2 feet. Pkt. 10 cts., oz. \$1.00.

Remember we deliver free at catalogue prices-except where noted. Write for special prices in large quantities. 


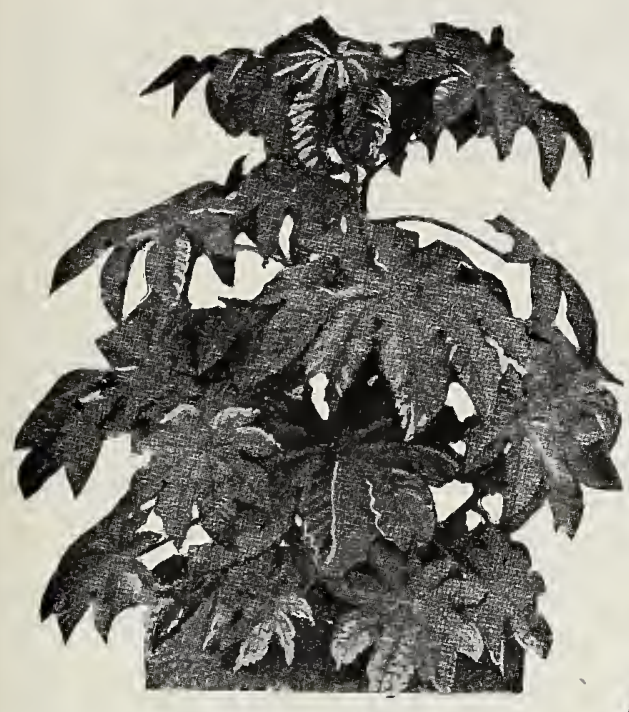

Ricinus Zanzibariensis.

\section{SCABIOUS \\ (Mourning Bride)}

The flowers of the double scabious are of peculiar form and diversified coloring, varying from white to rose, crimson or purpie, and are quite fragrant. The flowers are borne on long stems, and if cut as soon as the buds expand, will last a long time. Hardy annual. 18 to 24 inches. Plkt. 5 cts., oz. 50 cts.

\section{SCARLET RUNNER}

One of the most ornamental varieties of the bean family, of rapid growth and producing dazzling scarlet flowers from July to October. For training on verandas and over unsightiy objects, it will be found very useful and the beans may be cooked in the same way as the Lima. Bean. Hardy annual. 20 to 40 feet. Plkt. 5 cts., $1 \mathrm{lb} .50 \mathrm{cts}$.

\section{SCARLET SAGE}

The Salvias, or Scarlet Sage, are extremely popular and satisfactory bedding plants, bearing long spikes of dazzling scarlet flowers from July until frost. The seed should be sown indoors as early as possible in a temperature of 60 to 70 degrees. Cover the seeds to a depth of only four times their size and press the soil firmly on them, watering with a fine spray as needed, never allowing them to dry out. Set out in the open border when all danger from frost is past. Half-hardy perennial. $2 \frac{1}{2}$ feet. Pkt. 10 cts., oz. $\$ 4.00$.

\section{SENECIO}

A dwarf summer bloomer, very much admired on rockeries and useful for winter blooming in the conservatory or window box. Hardy annual. 1 foot. Pkt. $10 \mathrm{cts}$, oz. $\$ 1.00$.

\section{SENSITIVE PLANT (Mimosa Pudica)}

A curious and interesting half-hardy annual with pinkish flowers. Leaves close when touched. Pkt. 5 cts., oz. 50 cts. Mixed. Plit. 10 cts., oz. 25 cts.

\section{RICINUS (Castor Oil Plant)}

Large annual foliage plants of rapid and luxuriant growth, attaining a across, of majestic sub-tropical effect.

Sanguineus. The stalks and fruit are blood red, foliage green. Pkt. 5 Zanzibariensis. The plants grow to immense size, branching widely and

\section{RUDBECKIA}

A strong and quick growing plant, bearing immense quantities of yellow stowers suitable for planting in clumps or among shrubbery.

Bicolor Superba. Hardy annual. Yellow with brown center. Height 3 feet. Pkt. 10 cts., oz. $\$ 1.00$.

Bright yellow. Height 3 feet. Pkt. 10 cts., oz.

\section{SALPIGLOSSIS}

Highly ornamental autumn-blooming plants with funnel-shaped flowers curiously veined and marked, of easy culture, but best suited to light, sandy soil. Half-hardy annual. 18 inches. Pkt. 10 cts., oz. \$1.25.

\section{SANVITALIA}

A pretty dwarf annual with yellow flowers suitable for beds and rock work. Hardy annual. 5 inches. Pkt. 10 cts., oz. $\$ 1.00$.

\section{SALVIA(See Scarlet Sage)}

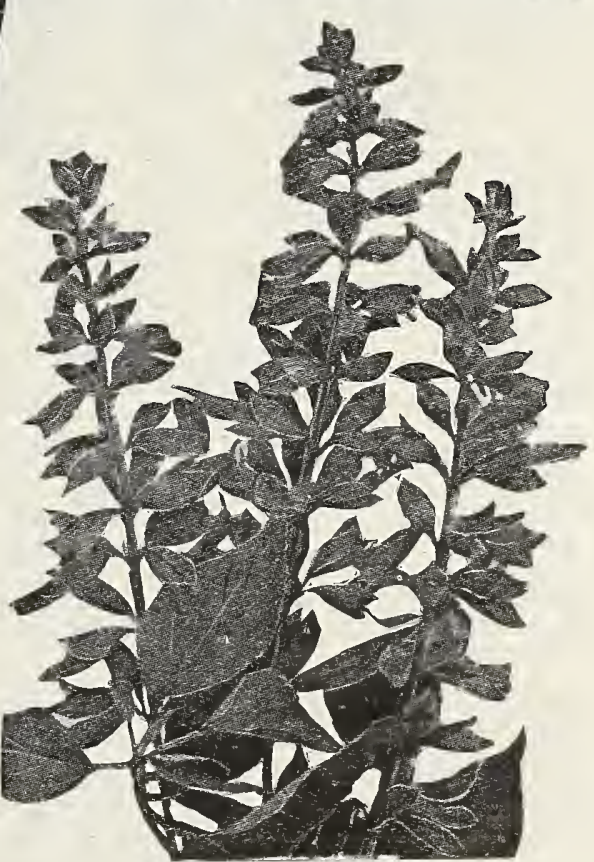

Salvia or Scarlet Sage.

Remember we deliver free at catalogue prices--except where noted. Write for special prices in large quantities. 


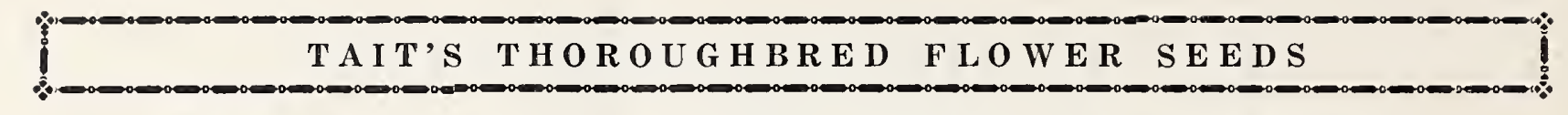

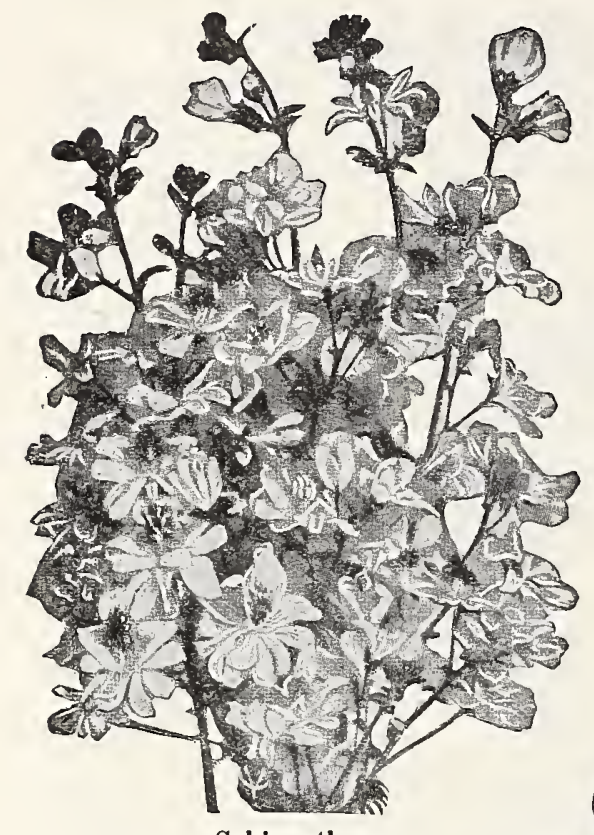

Schizanthus.

\section{SUNFLOWER DOUBLE}

Chrysant h e m u m Flowered. The flowers are bled, a rich golden yellow color, and much like Chrysanthemums. 7 feet. Pkt. 5 cts., oz. 25 cts.

\section{STOCKS}

This flower has long been considered invaluable by gardeners, being admirably adapted for bedding, massing, edging or ribboning. There are few sights more beautiful than a fine bed of these plants in full bloom. The duration and delicate fragrance of the flowers commend it very
strongly for pot culture in the house. If desired for earlv use, sow the seed indoors and transplant when the ground becomes warm, forcing with weak liquid manure. Hardy annual. 1 to $2 \mathrm{ft}$.

Dresden Perpetual, (or Cut and Come Again.) An stock producing excedingly beautiful strain of stock, producing immense spikes of flowers in great profusion from midsummer until frost. The flowers are unusually large and embrace a wide range of most beautiful and varied colors. 2 feet.

Blue ...Pkt. 25 cts. Oz. $\$ 4.00$ Red ...Pkt. 25 cts. Oz. 4.00 Pink ...Pkt. 25 cts. Oz. 4.00 Mixed..Pkt. 25 cts. Oz. 4.00 White..Pkt. 25 cts. Oz. 4.00

\section{Large Flowering Ten Weeks Stocks.}

A splendid early blooming variety, extensively used for pot culture and summer bedding. 1 foot.

Blue ...Pkt. 10 cts. Oz. $\$ 2.50$ White..Pkt. 10 cts. Oz.. 2.50 Rose ..Pkt. 10 cts. Oz..2.50 Mixed..Pkt. 10 cts. Oz.. 2.59

\section{SUMMER CYPRESS}

(See Kochia.)

\section{SILENE, OR CATCHFLY}

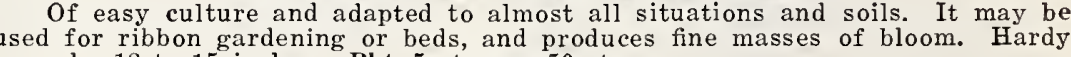
annual. 12 to 15 inches. Pkt. 5 cts., oz. 50 cts.

\section{SMILAX} delicate colors of the flowers. Tender perennial. 8 to 10 feet. Pkt. 10 cts., oz.

While these strong growing plants are unsuitable for bedding, they are very SUNFLOWER useful for massing in shrubbery or borders, and for sereening purposes. They do well in sunny positions in any kind of soil.

\section{SINGLE}

Small single, rich yellow flowers with black centers. Branching in habit and good for cutting. 4 feet. Plt. 10 cts., oz. 40 cts.

Perkeo. This dwarf variety of the minibushes about 12 inches high by 14 inches through. Pkt. 10 cts., oz. 60 cts.

Stella Beautiful small flowers of golden Stella. yellow with black disk, borne gracefully on long stems, constantly in bloom from early summer until frost. Height 4 feet. Pkt. 10 cts., oz. 60 cts.

Red. The plants of this Sunflower grow Red. about eight feet high and produce single flowers of a rich chestnut red, with some red, tipped with yellow, while some will be entirely yellow. Pkt. 10 cts., oz. 50 cts. Mammoth Russian. The old standety wall variety with large yellow flowers with dark center. 8 feet. Pkt. 5 cts., $1 / 4$ lb. 10 cts. 


\section{TAIT'S THOROUGHBRED GIANT WAVED SPENGE R SWEET PEA S}

The dainty form and exquisite colors of the Sweet Pea made it generations ago one of the best-loved flowers, but its popularity has grown immensely during the last decade, owing to improvements which have really brought about a transformation of the flower. The introduction of the Spencer type has more than doubled the size of the blossom, beautiful undulations and flutings have been developed, and the stems have become very long and stout. So eagerly is the coming of the Sweet Pea awaited, that enormous quantities are forced for market by florists, finding sale at fancy prices before the outdoor crop is available. Almost anyone living near a city will find the cultivation as profitable as it is simple, especially if care is taken in gathering and bunching, so that the delicate blossoms and tendrils are not bruised.

Sweet Peas may be sown either in the fall or early spring. For the best results, the soil should be deep and heavily manured, and if possible the situation should be one which permits the vines to get air and sunshine on both sides, although there is no difficulty in growing them against a fence. The usual custom is to dig a trench ten inches deep, into which put four inches of well rotted manure and cover with two inches of good soil. Sow the peas on top of this about half an inch apart, and cover with two inches of earth. Before covering, it is a good plan to scatter tobacco dust liberally on the peas as a preventive of lice. As the plants develop the earth is gradually drawn to them until the furrow has been filled, the roots being thus kept from the surface heat in summer. We think it is a good plan to make a little trench parallel with the row, flooding it occasionally during dry weather, and a mulch of leaves or lawn sweepings will be found very helpful; sprinkling of the vines does harm rather than good and watering should be done at the roots only. Sweet Peas make a great deal of vine under proper conditions and it is always best to thin them out to about an inch in the row as soon as they are well out of the ground. if the blossoms are picked regularly, they will bear until killed by either extreme heat or frost, the flowering season being naturally longest in. cool climates. In most parts of the South, it is very easy to bring Sweet Peas into bloom very early in the year by sowing in October or November, and it is a pity more gardeners do not take advantage of this simple method of gaining a month or more. A light dressing of manure over the surface will prevent the ground freezing too deeply, and they rarely suffer from such cold as we have in the South. Hardy annual. 6 feet.

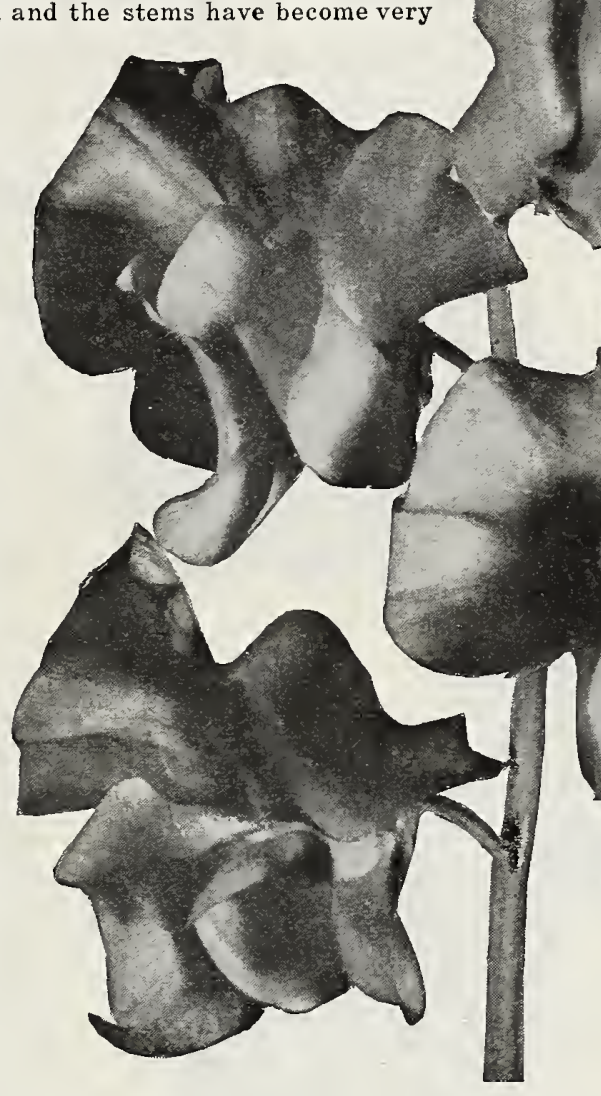

\section{TWO BEAUTIFUL NEW SPENGER SWEET PEAS}

Mary Pickford. One of the latest introductions in Pink Spencer Sweet Peas. The color is a beautiful dainty light cream pink, a color combination difficult to equal. The flowers are perfectly formed on long stout MERIT at the National Sweet Pea Societies Annual Trials. 25c cts. per packet, containing twelve seeds each. Postpaid.

Miss California. In Miss California we have a Sweet Pea Novelty which compels admiration and attention from an a word picture as the blending of the shades is so perfect and wonderful. The general effect is a rich, beautiful salmon cream pink of a distinctly new shade. The flowers are large, beautifully waved and borne in fours on long, stout stems. The plant is an exceptionally vigorous grower and cannot but give satisfaction to everyone. 25 cts. per packet, containing 12 seeds each. Postpaid. 


\section{NEW EARLY or WINTER-FLOWERING SPENCER SWEET PEAS}

Glitters. An attractive and pleasing shade of brilliant orange scarlet. Pkt. 15 cts., oz. 75 cts. Postpaid.

Hercules, A shade of pink closely resembling Countess Spencer. The flowers are borne on long stems and mostly four large well-waved blossoms to each stem. Pkt.15 cts., oz. 75 cts. Postpaid.

Liberty. Nothing yet introduced has approached this deep sun proof crimson, or blood red. It is the color of King
Edward Spencer. Pkt. 15 cts., oz. 75 cts. Postpaid. Morning Star. A deep orange scarlet in the standard, orange and pink in the wings. Pkt. 15 cts., oz. 75 cts. Postpaid. Snow Flake. This is the best EARLY FLOWERING WHITE variety. It is much appreciated by florists as the large Fake. flowers are borne on long straight stems. Pkt. 15 cts., oz. 75 cts. Postpaid.

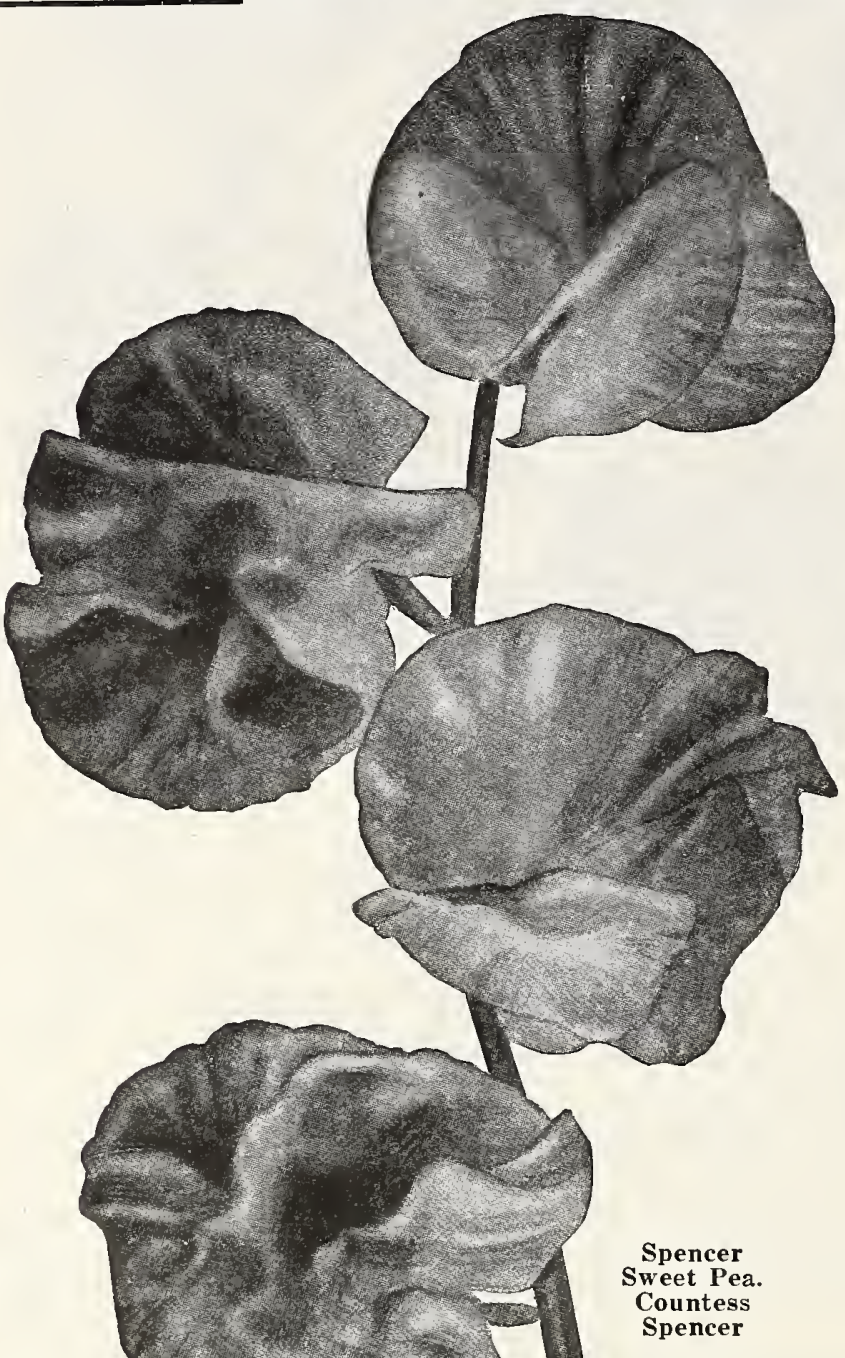

Harmony. The color is a rich lovely lavender, and the 15.towers are large, borne on long stems. Pkt. $\overline{15 \text { cts.. oz. } 75}$ cts. Postpaid.

Yarrawa. Bright Rose pink, with creamy base and rer wings. Very popular for either outdoor or greenhouse planting on account of its extreme earliness. Pkt. 15 cts., oz. 75 ets. Postpaid.

Zvolanek's Rose. A free blooming and easily grown arearre variety. The large bold flowers are carried in fours on long and strong stems. One of the best in the deep pink class. Pkt. 15 cts., oz. 75 cts. Postpaid.

\section{Giant Waved or Spencer Sweet Peas}

\section{BLUE OR PURPLE SHADES}

Flora Norton. Very brilliant, almost a bright blue, 10 cts., oz. 35 cts., $1 / 4$ lb. $\$ 1.00,1$ lb. $\$ 3.75$. Postpaid.

Margaret Madison. Clear azure - blue; flowers cts., oz. 35 cts., $1 / 4$ lb. $\$ 1.00,1$ lb. $\$ 3.75$. Postpaid.

Mrs. Tom Jones, Bright blue. Very perfect in form Irs. $10 \mathrm{~m}$ Jones. and a fine bloomer. Pkt. 10 cts. oz. 35 cts., $1 / 4$ lb. $\$ 1.00,1$ lb. $\$ 3.75$.

Royal Purple. A new shade in Sweet Peas almost a cts., 1/4 lb. $\$ 1.00,1$ lb. $\$ 3.75$. Postpaid.

Wedgewood. A splendid variety usually producing unique shade of blue. Pkt. 10 cts., oz. 35 cts., $1 / 4$ lb. $\$ 1.00$, 1 lb. $\$ 3.75$. Postpaid.

\section{LAVENDER SHADES}

Austin Frederick Improved. A l a r g e pure colored. Very large and wavy. Pkt. 10 cts., oz. 35 ets. $1 / 4$ lb. $\$ 1.00,1$ lb. $\$ 3.75$. Postpaid.

Florence Nightingale. A magnificent lavender gale. flower, standard wing s large and well waved. Pkt. 10 cts., oz. 35 cts., $1 / 4$ lb. $\$ 1.00$ 1 lb. \$3.75. Postpaid.

\section{MAROON}

Othello. Deep rich maroon; large flowers. Pkt. 10 cts., oz. 35 cts., $1 / 4$ lb. $\$ 1.00,1$ lb. $\$ 3.75$. Postpaid. Ravenswing. The darkest of all sweet peas yet introduced. An oz. 35 cts,. 1/4 lb. $\$ 1.00,1$ lb. $\$ 3.75$. Postpaid.

Warrior. Giant Maroon. Flowers well formed. Pkt. 10 cts., Warrior. oz. 35 cts., $1 / 4$ lb. $\$ 1.00,1$ lb. $\$ 3.75$. Postpaid.

Remember we deliver free at catalogue prices-except where noted. Write for special prices in large quantities. 


\section{PINK SHADES}

Apple Blossom. Standard very bright rose, wings Ak primrose with a flush of rose tint. Pkt. 10 cts., 0z. 35 cts., 1/4 ib. $\$ 1.00,1$ lb. $\$ 3.75$. Postpaid. Sunset. Magnificent flowers of a pleasing rose shade. Ponset. Pkt. 10 cts., oz. 35 cts., $1 / 4$ lb. $\$ 1.00,1$ lb. $\$ 3.75$. Postpaid.

Countess Spencer. Possibly the best bright pink; with long stems. Pkt. 10 cts., 0z. 35 cts., $1 / 4 \mathrm{lb} \$ 1.00,1 \mathrm{lb}$ \$3.75. Postpaid.

Helen Lewis. Giant Orange Pink with wavy edges. An Helen LeWis. extremely handsome pea. Pkt. 10 cts. oz. 35 cts., $1 / 4$ lb. $\$ 1.00,1$ lb. $\$ 3.75$. Postpaid.

Margaret Atlee An exquisite shade of salmon pink Merfectly suffused over a cream ground. Pkt. $10 \mathrm{cts.}$, oz. 35 cts., $1 / 4$ ib. $\$ 1.00,1$ lb. $\$ 3.75$. Postpaid.

Youth. This new variety has large flowers picotee edged oz. 50 cts., $1 / 4$ lb. $\$ 1.50,1$ lb. $\$ 5.00$. Postpaid.

\section{PRIMROSE OR CREAM SHADES}

Mrs. Hugh Dickson. Apricot pink and buff. The most pleasing. Pkt. 10 cts., oz. 35 cts., $1 /, 1 b$, but bright and Postpaid.

Illumination. Similar to Exquisite, but a striking selfcolor of deep rose. Pkt. 10 cts., oz. 35 Picture. The flowers, which are of the largest size, are well waved, and exquisitely frilled on the edges. The color is a blend of cream and pink shades, having deeper flush on the wings. Pkt. 10 cts., oz. 35 cts., 1/4 lb. $\$ 1.00,1$ lb. \$3.75. Postpaid.

Rosabelle. Deep rose self, with a white blotch at the oz. 35 cts., $1 / 4$ lb. $\$ 1.00,1$ lb. $\$ 3.75$. Postpaid.

Hebe. A rich clear pink variety. The vine makes a robust usually borne in fours on strong stems. Pkt. 10 cts., oz. 35 cts., $1 / 4$ lb. $\$ 1.00,1$ lb. $\$ 3.75$. Postpaid.

Primrose Spencer. The finest of its class, clear primrose. Pkt. 10 cts., oz. 35 cts., $1 / 4$ lb. $\$ 1.00,1$ lb. $\$ 3.75$. Postpaid.

\section{RED SHADES}

George Herbert. One of the gorgeous Spencers, with Pkt. 10 cts., oz. 35 cts., $1 / 4$ lb. $\$ 1.00,1$ lb. $\$ 3.75$. Postpaid.

Illuminator. A beautiful orange-salmon Sweet Pea, Illuminator. which in a brilliant sunshine or under cts., oz. 35 cts., $1 / 4 \mathrm{lb}$. $\$ 1.00,1 \mathrm{lb}$. $\$ 3.75$. Postpaid.

King Fdward. This is easily the showiest of all the King Edward. This is easily the showiest of all the so elaborately frilled and fluted. The standards will often measure full two inches across, and the wings are of proportionate size, while the stout stem carries easily its burden of three or four of these giant blossoms. Pkt. 10 cts., oz. 35 cts., $1 / 4 \mathrm{lb}$. $\$ 1.00,1 \mathrm{lb} . \$ 3.75$.

\section{WHITE}

Constance Hinton. This black seeded, white flowered variety is very popular. The flowers are of large size, and the vines strong and vigorous. Pkt. 10 cts., oz. 35 cts., 1/4 lb. $\$ 1.00,1$ lb. $\$ 3.75$. Postpaid.

King White. The most exquisite White Sweet Pea ever introduced, King White. and a revelation to those who are not acquainted with blossoms, the petals of extraordinary size and very beautifully waved and fluted. Pkt. $10 \mathrm{cts}$., oz. $40 \mathrm{cts}$., $1 / 4 \mathrm{lb}$. $\$ 1.25,1 \mathrm{lb}$. $\$ 4.00$. Postpaid.

\section{TAIT'S THOROUGHBRED MIXTURE}

Composed of over fifty of the most beautiful Spencers. This represents the climax in Sweet Peas, and will give infinite pleasure to all lovers of flowers. Wherever we send a package it invariably proves to be the most effective of advertisements, so that we now enjoy a great reputation for Sweet Peas. Pkt. 10 cts., oz. 30 cts., $1 / 1 /$ lb. 90 cts., 1 lb. $\$ 2.75 . \quad$ Postpaid.

\section{SWEET WILLIAM (Dianthus Barbatus.)}

An ever popular favorite, producing the richest effect in beds and mixed flower borders. The improved varieties are much superior to oldfashioned sorts, being very large and handsomely tinted. Hardy perennial. $1 \frac{1}{2}$ feet.

Single Giant Mixed. Pkt. 10 cts., oz. 75 cts. Double Giant Mixed.

Pkt. 10 cts., oz. 75 cts.
The lover of carmine shades will be delighted with this wonderful new variety. The flowers 35 cts., 1/4 lb. \$1.00, 1 lb. \$3.75. Postpaid.

proaching the color of a tan-

ored crimson and practically sunwill frequently have four flowers. Pkt. 15 cts., oz. 50 cts.,

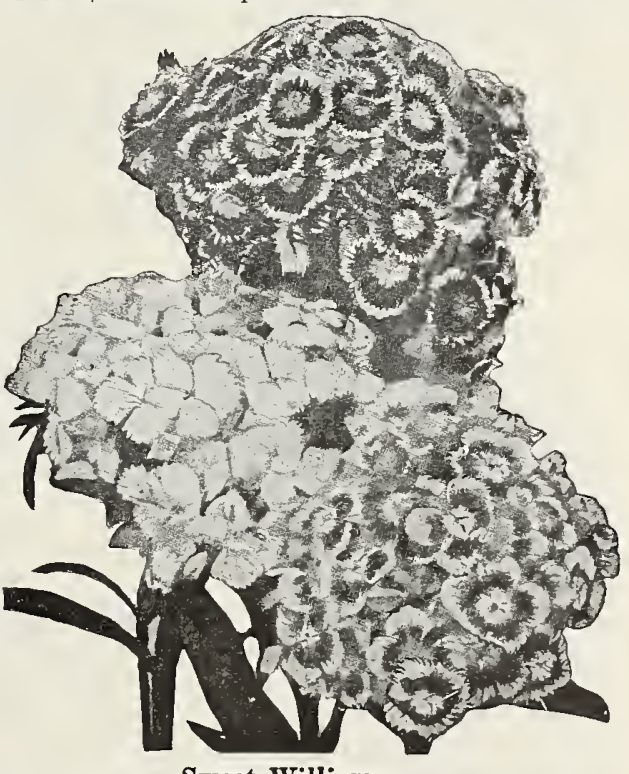

Remember we deliver free at catalogue prices-except where noted. Write for special prices in large quantities. 


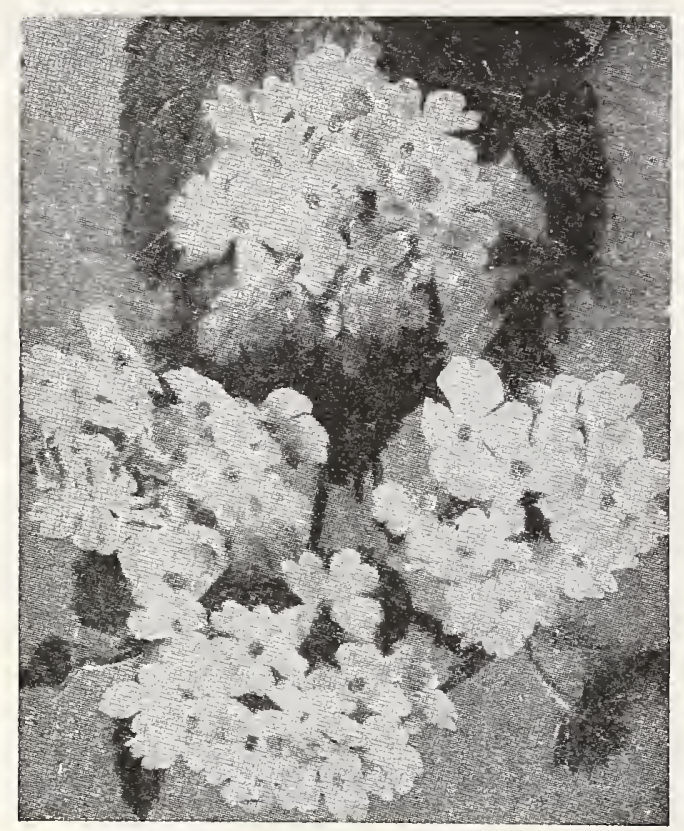

Verbena.

\section{THUNBERGIA}

Beautiful rapid annual climbers, used extensively for hanging baskets, window boxes, etc. The flowers are very pretty, colors ranging from white to bright orange, the center always dark. It prefers a warm, sunny situation. Half hardy annuals. 4 feet. Pkt. 10 cts., oz. \$1.25.

\section{VERBENA}

As a bedding plant the Verbena is universally regarded as invaluable, and few plants are better for window boxes, since it is never out of bloom during the season. Although perennial, they bloom from seed the first year, flowering in August if sown in May. A better way is to sow the seed in boxes or hot-beds early in March and transplant when all danger of frost is past. Verbenas from cuttings are less vigorous than those grown from seed. Half-hardy perennial. 5 inches.

Pink..................... Pkt. 10 cts. Oz.....\$1.00

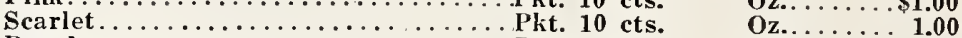

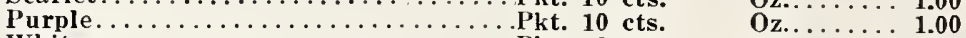

White ..........................

Fine Mixed.......................

Finest Hybrid Italian. This seed is saved from splendid and named varieties, and is absolutely unsurpassed for diversified brilliancy of color. The trusses are of extraordinary size, the individual flowers very perfect and the plant is remarkably vigorous. Pkt. 10 cts., oz. $\$ 1.25$.

\section{VINCA}

The Vinca or Periwinkle is a perennial and must be sown early to obtain flowers the first season. It blooms freely until frost and may then be potted and brought into the house, where it will continue flowering all the winter. Those who have sunny situations where other flowers suffer in mid-summer will find the Vinca almost sunproof' if a reasonable amount of water is given. Tender perennial. 1 foot. Mixed. Pkt. 10 cts., oz. 75 cts.

\section{WALLFLOWER}

These well known deliciously fragrant half-hardy perennials are among our earliest spring flowers. Since the plant will endure very. low temperatures, no protection is needed here in winter, and their indifference to heat and drought adds to their value in the south. 1 to 2 feet.

Single Mixed. Pkt. 10 cts., oz. $\$ 1.00$.

Double Mixed.

Pkt. 10 cts., oz. $\$ 1.00$.

Paris Extra Early. Flowers beautifully the first season, and we recommend it urreservedly. Pkt. 10 cts., oz. \$1.00.

\section{TAIT'S 'THOROUGHBRED ZINNIAS NEW AND IMPROVED STRAINS}

No summer flowering annual can equal our new types of Zinnias for continued blooming, and gorgeous color display.

\section{PICOTEE ZINNIA}

The flowers of this type, while not quite as large as the Double Giants, are very attractive in appearance, as the edges of the petals are well marked with distinct colors to the body of the flower, making them very attractive as bedders and cut flowers. This type does not reproduce more than 60 per cent. true.

Mixed Colors. All colors mixed, including new colors 5 pkts. $\$ 1.00$.

\section{DOUBLE QUILLED ZINNIA}

Victory. A very distinct variety with large densely douicter. bled quilled flowers. Our Mixture includes several new colors. This variety has been greatly improved in size and range of color during the past year. Pkt. 15 ets., 2 pkts. 25 cts.

\section{CURLED OR CRESTED ZINNIA}

This sort is a selection of the past few years, and now comes from seed almost entirely true. The petals are long, twisted and curled, giving the flowers a most attractive appearance. Mixed colors. Pkt. 10 cts., oz. $\$ 1.50$.

\section{DWARF ZINNIAS}

Dwarf Lilliput. This variety grows about a foot high, that are literally enveloped with flowers. Mixed colors. Plit. 10 cts., oz. $\$ 1.50$.

Red Riding Hood. Growing but a foot high, this fective in the border little compact plant is highly efsmall, double scarlet flowers. covered the entire season with small, double scarlet flowers. Pkt. 10 cts., 3 pkts. 25 cts. 
GEO. TAIT \& SONS, INC, NORFOLK, VA.

\section{Tait's Grand Double}

\section{Dahlia Flowered Zinnias}

We wish to call special attention to the following new varieties of the Dahlia Flowered Zinnia. This year we are offering in addition to our mixture, five distinct shades, which we believe will please the most critical eye. The large size, beautiful form and exquisite coloring will delight all lovers of these gorgeous flowers.

Exquisite. Color light rose with center deep rose. We Ex melieve this the most pleasing of our collecOld Rose. Color adequately described by name, and for Q charm and beauty we consider it ranks next to Exquisite. Pkt. 20 cts.

Crimson Monarch. The largest and best of the red Ciscies. Plants are very vigorMeteor. A rich, Meteor. A the red shades. Very large and of fine form. Pkt. 20 cts.

Buttercup. An immense deep creamy yellow. A very Butercup. desirable flower. Pkt. 20 cts.

Collection. One packet each of the above five varieties Collection. for $75 \mathrm{cts}$.

Double Dahlia Flowered Mixed. Our mixture wonderful range of colors. Pkt. 15 cts., 2 pkts. 25 cts.

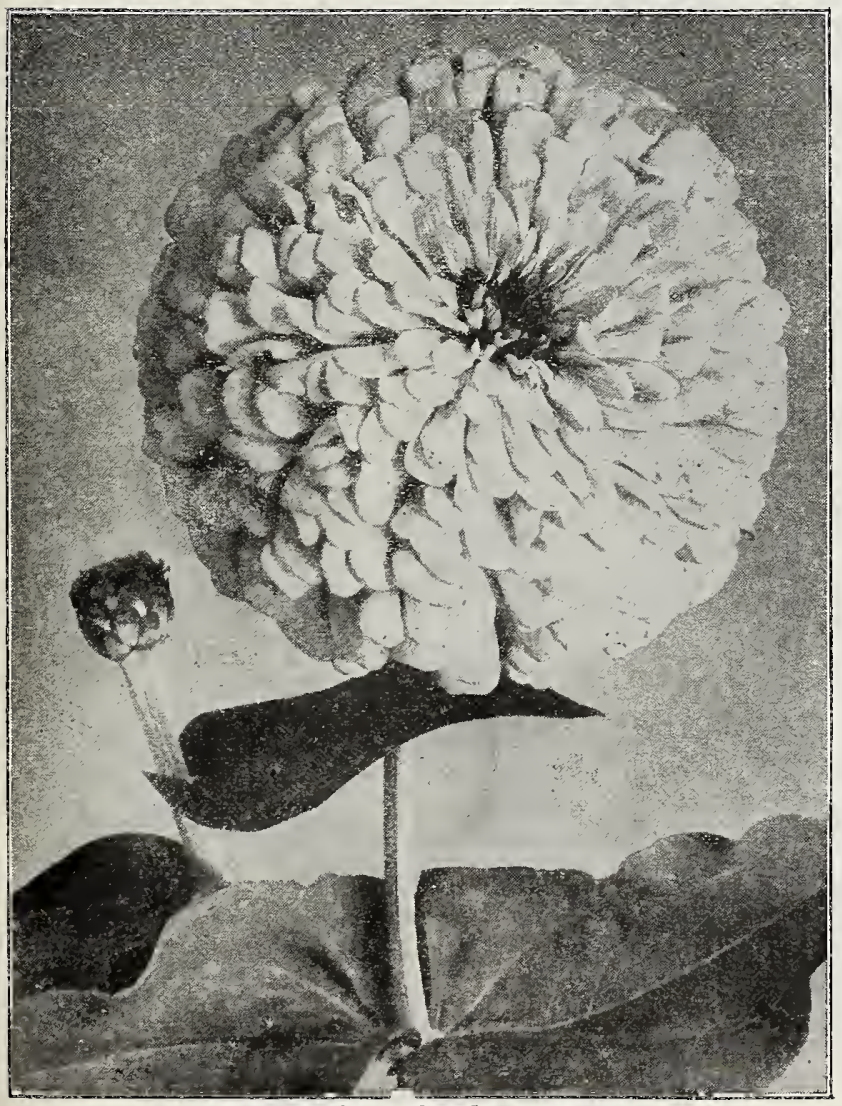

Superb Giant Double Zinnia

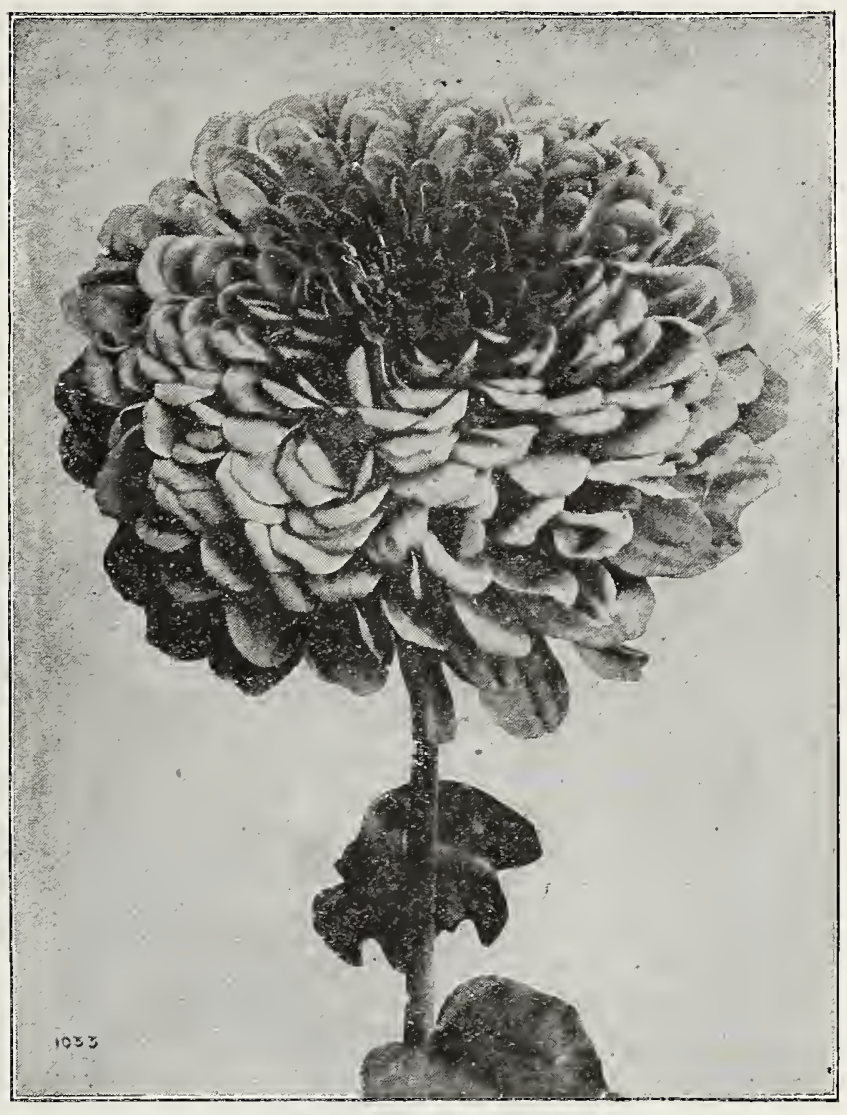

Grand Double Dahlia Flowered Zinnia.

\section{Tait's Superb}

\section{Double Giants Zinnias}

\section{(Grandiflora Robusta)}

Because of their usefulness for borders, beds, or cut flowers, this popular annual has long been a general favorite. The large, double flowers are borne on long stiff stems, and the plants are of branching habit, growing from two to three feet high. They flourish luxuriantly in the hottest situations, and require hardly any attention beyond an occasional stirling of the soil.

Apricot Orange ................. 10 cts. Oz...\$1.25 Shrimp Pink .................. 10 cts. Oz.... 1.25 Crimson ....................... 10 ets. Oz.... 1.25 Violet $\ldots \ldots \ldots \ldots \ldots \ldots \ldots \ldots \ldots$. Pkt. 10 cts. Oz.... 1.25 White $\ldots \ldots \ldots \ldots \ldots \ldots \ldots \ldots \ldots$ Pkt. 10 ets. Oz.... 1.25 Yellow .................. Pkt. 10 cts. Oz.... 1.25 Double Giants Mixed Colors......Pkt. 10 cts. Oz.... 1.00

Remember we deliver free at catalogue prices-except where noted. Write for special prices in large quantities. 
THE gorgeous flowers and splendid foliage of the Canna are gaining for it greater popularity each season. No lawn or 1 park seems complete without its tropical leaves and its mammoth flower spikes that are a mass of bloom from July until frost. Our list contains only varieties of merit.

CULTURE.-Although astonishing success with Cannas will often be had under most unpromising conditions, they respond so luxuriantly to care that it is well worth while to take a little trouble at the start. The bed should be spaded to a depth of at least a foot, an abundance of well-decomposed manure worked in, and the roots set four or five inches under the surface. "The "blazing" effects for which Cannas are so famous are best secured by the use in masses, with the roots set not more than two feet apart-dwarf kinds being set even more closely. All Cannas love water, and in dry seasons blooming will be much more profuse and constant if the soil be kept always moist. In the South, planting may be done as early as the last of March, but if early bloom is wanted, the best way is to start them in pots under protection, transplanting to the open ground when danger of frost has passed. Unless taken up before freezing weather, the roots should be covered with litter for the winter.

\section{PINK}

Wabash. (Bronze Leaved.) The bronze leaved Rosea mine-pink and very large to carusual canna. 4 feet. 20 cts, each, $\$ 2.00$ per doz. Postpaid.

City of Portland. (Green Foliage.) A wonderful bright rosy-pink, with flowers of the largest size and a free-flowering, vigorous grower. $3^{1 / 2}$ feet. 20 cts. each, $\$ 2.00$ per doz. Postpaid. Mrs. Alfred F. Conard. (Green Folidid broad heads, clean and full petaled; silver pink. Height 4 feet. 15 cts. each, $\$ 1.50$ per doz. Postpaid.

Rosea Gigantea. (Green Foliage.) A pleasing shade of pink, large flowers, and a free bloomer. Height 4 feet. 15 cts. each, $\$ 1.50$ per doz. Postpaid.

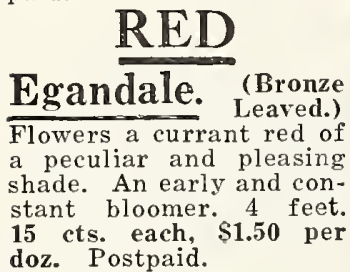

$\mathrm{K}$ i n $\mathrm{g}$ Humbert.

(Bronze Foliage.) A most popular variety; color, orange scarlet shaded with crimson. The foliage is of the deepest bronze. Height 4 feet. 15 cts. each, $\$ 1.50$ per doz. Postpaid.

Meteor (Green Foliage.) Deep dazzling crimHeight 5 feet. $\mathbf{1 5}$ cts. each, $\$ \mathbf{1 . 5 0}$ per dozen. Postpaid.
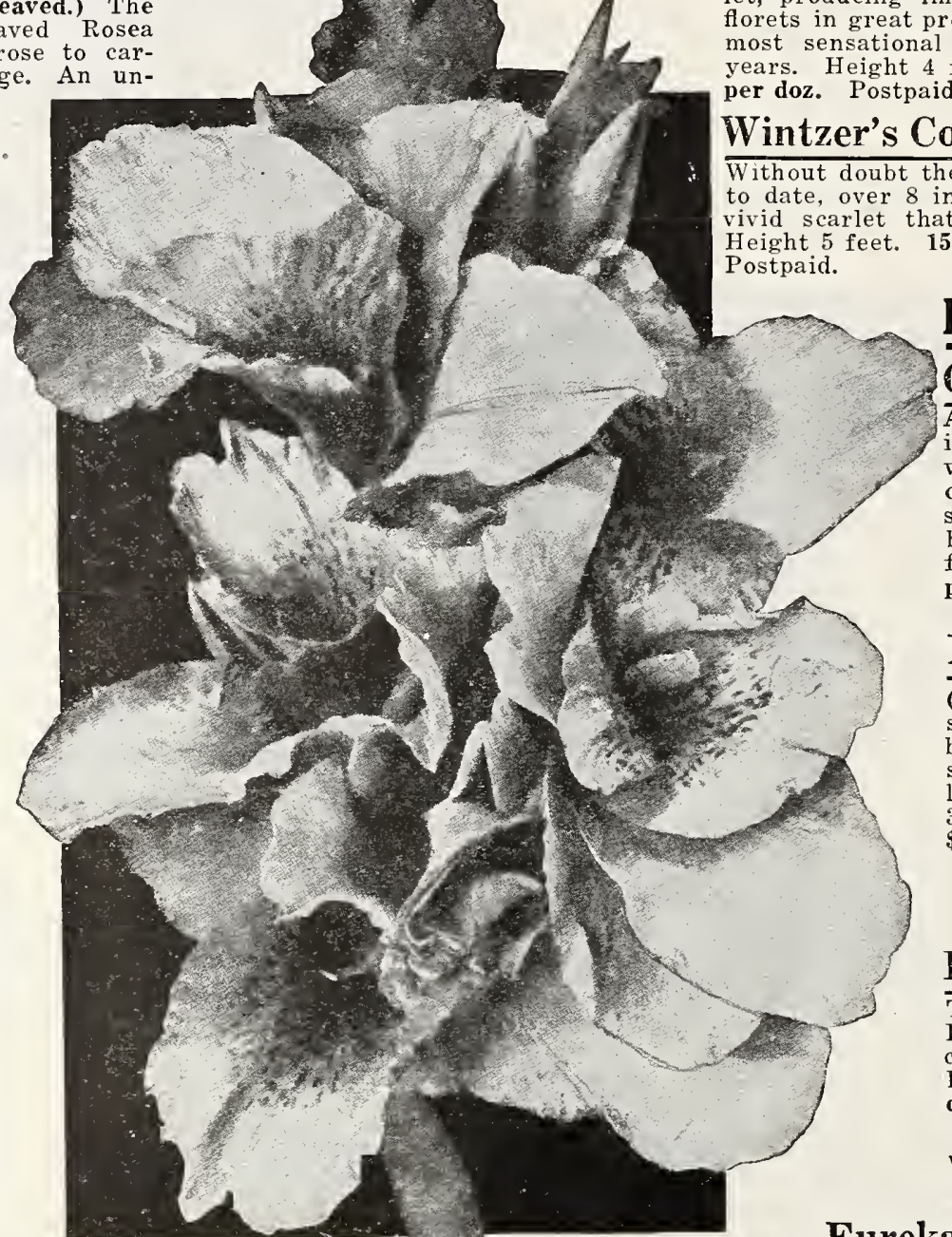

Eureka (Green Foliage.) The Canna King Humbert. have broad petals of a creamy Height $4 \frac{1}{2}$ feet. Each 20 cts., $\$ 2.00$ per doz. Postpaid.

Remember we deliver free at catalogue prices-except where noted. Write for special prices in large quantities. 


\section{A H L I A S Tait's Collection of Free Blooming Varieties}

This flower has been so much improved in recent years that no garden seems complete without it. Especially is this true of the type known as Decorative and Cactus Dahlias.

CULTURE.-They do best in rich soil and plenty of sun, but will grow in any good garden soil, and in almost any location excepting one very shady. The bulbs or tubers should be planted in April, about 4 inches deep and 30 inches apart. An inch square stake, 3 or 4 feet long should be stuck a foot in the ground when the roots are planted, and the plants tied to it when about 2 feet high.

\section{CACTUS DAHLIAS}

Bianca. This beautiful dahlia, of Hybrid Cactus type, Bianca. should be in every collection. Color a delicate pink lavender, flower carried erect on stout stems. 65 cts. each, \$6.50 per dozen. Postpaid.

Etendard de Lyon. Colossal Cactus. The petals are N. broad, curled and wavy, and form a flower fully 6 inches in diameter and 4 inches deep; yet without any stiffness or formality; its color is rich carmine rose. 65 cts. each, $\$ 6.50$ per dozen. Postpaid.

Dee-Lighted. Large pure white flowers, full and borne dozen. Postpaid.

Golden Gate Considered one of the best Dahlias in Golden Gate. existence. A grand flower of a deep golden yellow, tinted bronze or russet; very free; flowers immense size, 6 to 9 inches in diameter, extra long stems. 30 cts. each, \$3.C0 per dozen. Postpaid.

Kalif. A monster cactus of perfect form. Color is a rich Kalif. pure scarlet, and the flowers are borne on strong, 65 cts. each, $\$ 6.50$ per dozen. Postpaid.

Kriemhilde. Delicate pink, shading to white in the cen$\$ 3.50$ per dozen. Postpaid.

Libelle. A striking variety of clear, deep, rose-purple. Libelle. Very free flowering. $30 \mathrm{cts}$. each, $\$ 3.00$ per dozen. Postpaid.

Special Offer. One each of our Seven Splendid

Special Offer. Cactus Dahlias for $\$ 2.80$ postpaid.

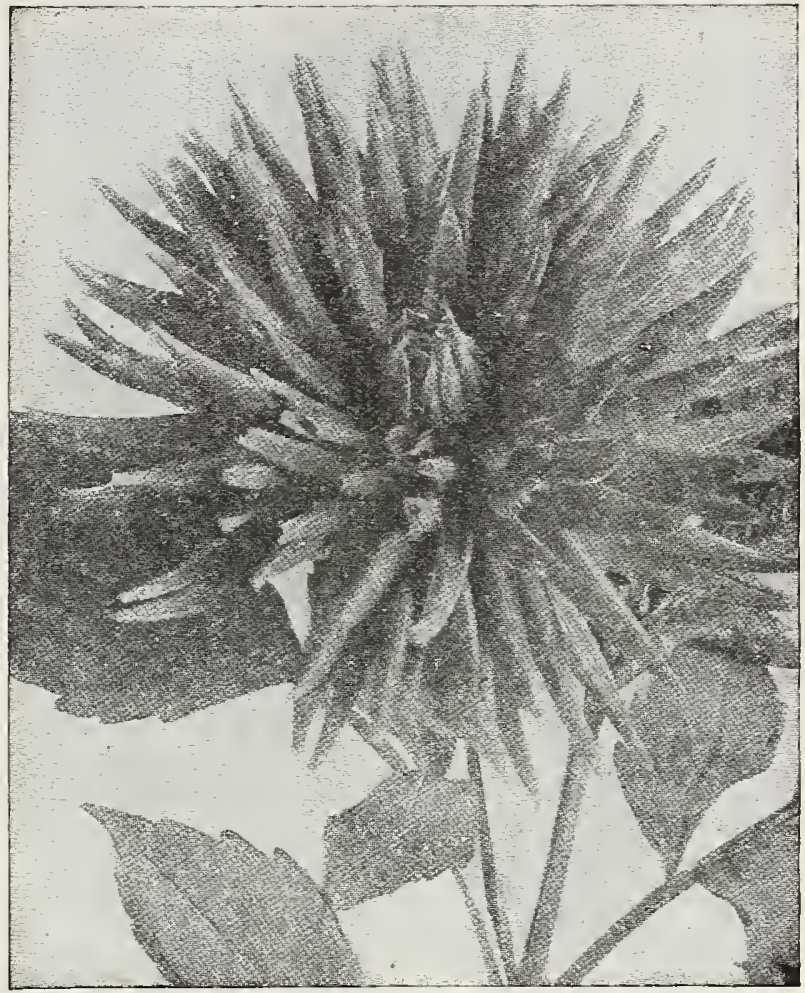

Libelle (Cactus Dahlia).

\section{FANGY SHOW DAHLIAS}

Arabella. Lovely primrose, shaded and tipped rose; a perfect and reliable Dahlia. 35 cts. each, \$3.50 per dozen. Arabella. Postpaid.

David Warfield. A dahlia of extra good habit, r, roducing mammoth flowers of a beautiful deep cherry red. The Lafle. stiff stems carry the flowers well above the foliage. 50 cts. each, $\$ 5.00$ per dozen. Postpaid. Grand Duke Alexis. Very large and full, with long thick quills overlapping at the end. Color white, slightly choicest varieties. 35 cts. each, $\$ 3.50$ per dozen. Postpaid.

Maude Adams. A wonderful dahlia in every respect. The color is a pure snow white, very effectively overlaid Miss Helen Hollis. One of the largest and finest deep scarlet dahlias in existence. Creates a sensation wherever 1.ss Helen Hollis. seen. 40 cts. each, $\$ 4.00$ per dozen. Postpaid.

Storm King. The most reliable white show dahlia to date. The pure white flowers are produced on good stems, Yellow Duke. A free flowering long stemmed form of Grand Duke. Rich light yellow. $35 \mathrm{cts}$ each, $\$ 3.50$ per dozen.

Special Offer. One each of our Seven Fancy 


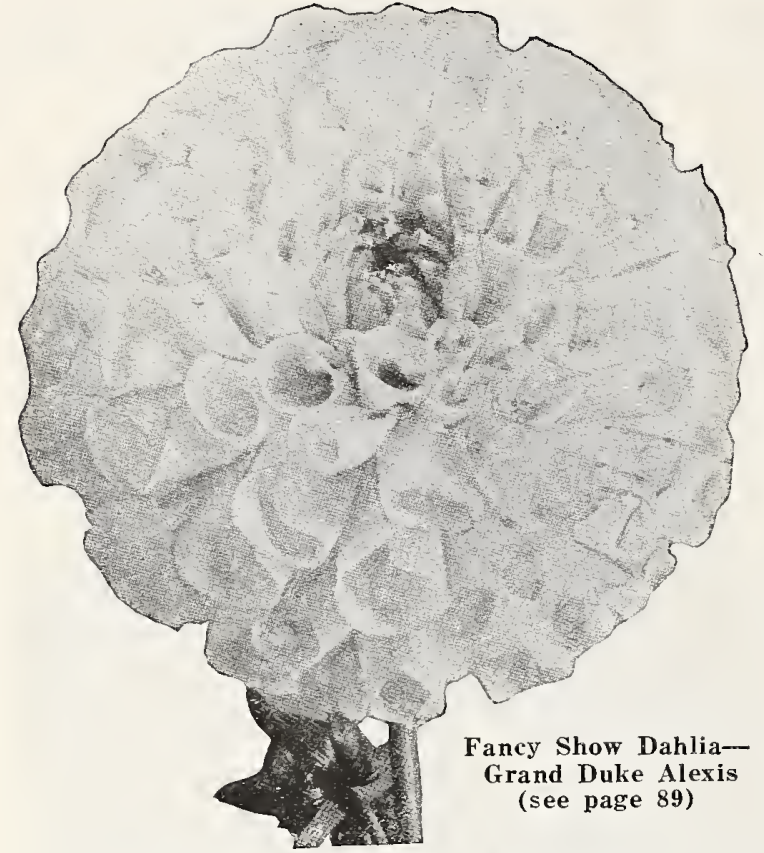

PEONY-FLOWERED DAHLIAS

\section{DECORATIVE DAHLIAS}

American Beauty. Flowers are of a gigantic size and produced on long, heavy steams, well above the foliage; color a gorgeous wine crimson. The best crimson Dahlia to date. 50 ets. each, $\$ 5.00$ per dozen. Postpaid.

Frank A. Walker. A charming shade of deep lavenderA. Walker. pink. Begins blossoming early and continues through the season. This Dahlia should be in every garden collection. 35 ets. each, \$3.50 per dozen. Postpaid.

Millionaire. Most delicate lavender with faint pink cast overshadowing it, the whole having a blending of white. An immense flower that attracts considerable attention on the exhibition table. $\$ 1.00$ each, $\$ 10.00$ per dozen. Postpaid.

Patrick O'Mara. This fine Dahlia is of very free flowering habit. The flowers are perfect in form, of good size, and supported on long stiff stems. The color is a rich chrome-yellow, with salmon red suffusion. $75 \mathrm{cts}$. each, $\$ 7.50$ per dozen. Postpaid.

Souvenir Douzon An immense flower; color a beautiful Souvenir Douzon. orange red; a very profuse bloomer and an unbeatable exhibition sort. Where care is taken in cultivation this Dahlia will easily produce blooms nine inches across. 30 cts. each, $\$ 3.00$ per dozen. Postpaid.

Washington City. A magnificent white flower of enor$60 \mathrm{cts}$ each, $\$ 6.00$ per dozen. Postpaid.

Yellow Colosse. Rich yellow; very large blooms; free to be the best yellow decorative to farm. Considered by some dozen. Postpaid.

Bertha von Suttrer. Good sized flowers produced Bertha von Suttrer. early and continuously, remaining of good quality to the end of the season, in color a pleasing salmon-pink with yellow suffusion. 50 ets each, $\$ 5.00$ per dozen. Postpaid.

Bertha Paulding. A very striking variety for the quisite, deep rose pink, garden. The flowers are of an exAltogether one of the best pinks of its type. 75 cts. each, $\$ 7.50$ per dozen. Postpaid.

City of Portland. Probably the largest and finest yellow Paeony Dahlia to date. The foliage. The stems are long, strong and erect, carrying the giant flowers in an upright position. The color is a clear, deep, rich golden yellow. 75 cts. each, $\$ \mathbf{7 5 0}$ per dozen. Postpaid.

Geisha. The showiest and most attractive of this type yet in form, con introduced; the rich colored flowers are original an effective and rich combination of scarlet and gold. 60 cts. each, $\$ 6.00$ per dozen. Postpaid.

Mrs. Bowen Tufts. One of the finest of the Peony tic, Flowered Dahlias, having gigantic, deep, rosy purple blossoms, which are produced well above the foliage upon long graceful stems. 35 cts each, $\$ 3.50$ per dozen. Postpaid.

Mrs. Newell D. Atwood. A very tall long stemmed Irs. Nree flowering variety. Its color is very rich and brilliant, a gorgeous deep crimson red. A strong sturdy grower. $60 \mathrm{cts}$. each, $\$ 6.00$ per dozen. Postpaid. Newport Dandy. A lilac pink of the most delicate with the shade. The yellow center is open with the inner petals curling and twisting over it. A very profuse bloomer. 65 cts. each, $\$ 6.50$ per dozen. Postpaid.

Special Offer. One each of our 7 Splendid Peony Flowered Dahlias, $\$ 3.75$, postpaid.
Special Offer. One each of our Seven Decora-

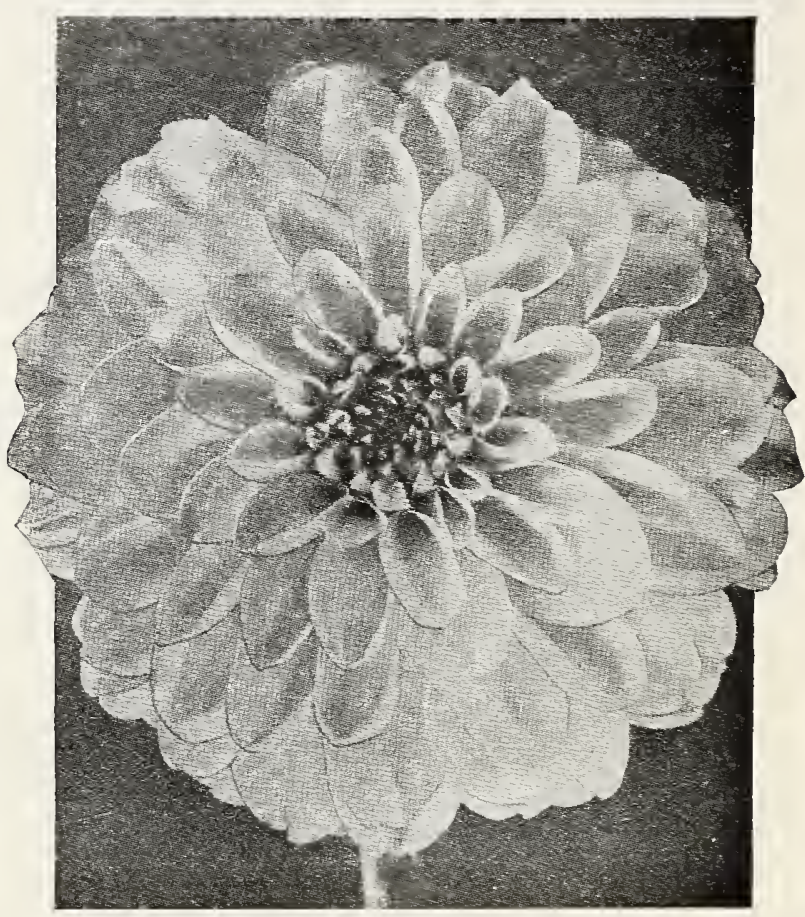

Decorative Dahlia-Frank A. Walker.

Remember we deliver free at catalogue prices-except where noted. Write for special prices in large quantities. 


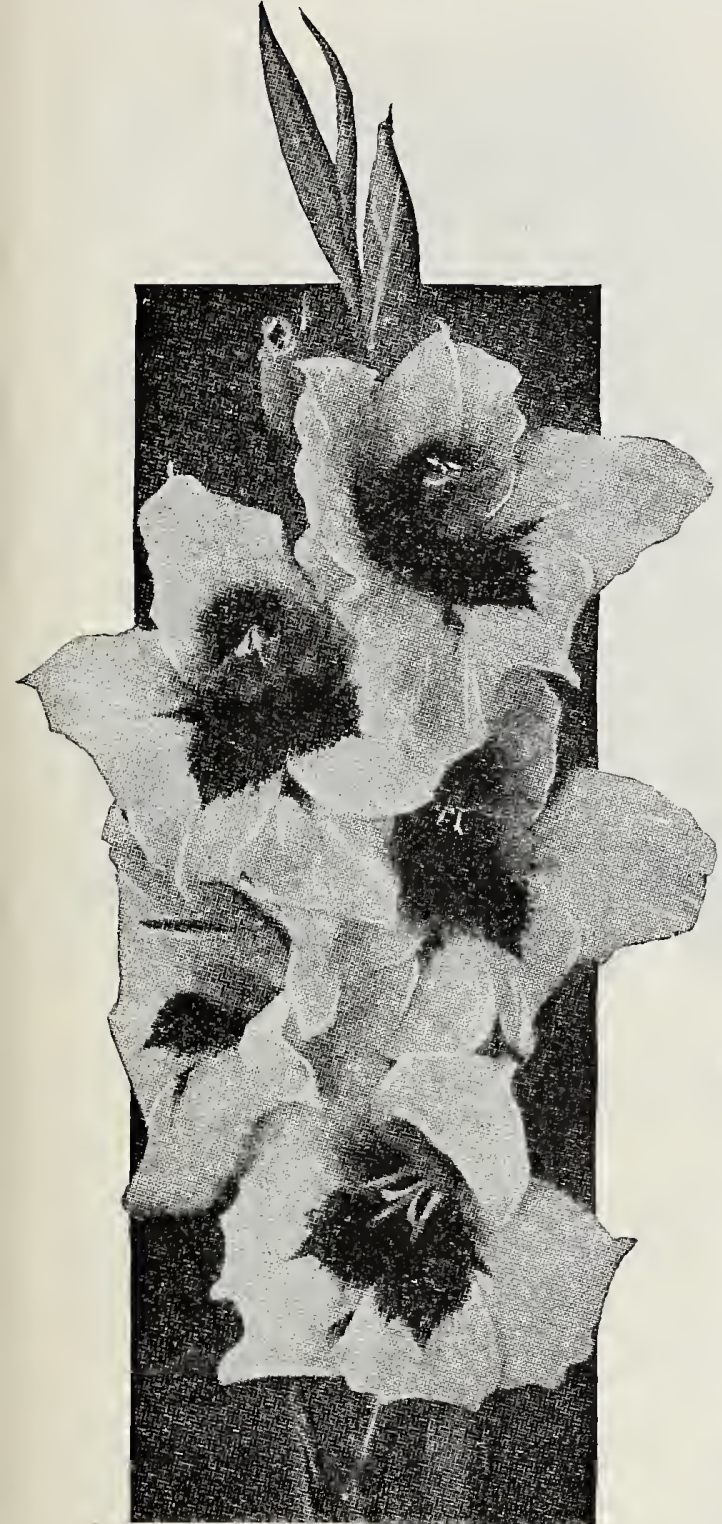

Gladiolus-Mrs. Frank Pendleton.

\section{GLADIOLUS}

\section{Twelve Splendid Named Varieties}

Gladiolus are so inexpensive, so easily grown and so beautiful, both in the garden and as cut flowers, that it is difficult to understand the general lack of interest in them.

CULTURE.-Any good soil is suitable and unlike most flowering bulbs in this climate, they not only do not deteriorate, but on the other hand, increase rapidly. Planting may be done at any time in April, May or June, the bulbs being set about three inches under the surface. As supports will be needed for the flowers, it is a good plan to put a dozen or more in a group around one stake, tying the stalks loosely to it. In the South the bulbs are best left in the ground and covered with litter for the winter.

America Soft lavender pink. Very popular with florists on account $\$ 4.00$ per 100 . Postpaid.

Baron Hulot. A fine blue Gladiolus, in color a rich, royal violet Baron Hulot. blue, very effective when combined with a yellow variety. 15 cts. each, $\$ 1.25$ per dozen, $\$ 8.00$ per 100 . Postpaid.

Crimson Glow. Well named, the color being a glowing crimsonCrimson Glow. scarlet, massive spikes and flowers of large size; a strong vigorous grower. 15 cts. each, $\$ 1.25$ per dozen, $\$ 8.00$ per 100 .

Flora. A new golden yellow variety of great excellence, being a free, Hora. strong grower with splendid spikes and flowers of large size. 15 cts. each, $\$ 1.25$ per dozen, $\$ 8.00$ per 100 .

Le Marechal Foch. This might briefly be described as an imLe Marechal Foch. proved America, having the same soft fleshpink color, but with much larger blooms and coming into flower two weeks earlier. Of unusually strong, vigorous growth with splendid straight, well-filled spikes. 15 cts. each, $\$ 1.25$ per dozen, $\$ 8.00$ per 100 .

Lily White. Immense white flowers with a touch of lavender in per 100. Postpaid.

Marjorie Gage. One of the best in our collection. The color is a lovely shade of light pink with deep red blotches altractive variety. Flowers are wide open and Postpaid.

Mrs. Francis King. A striking shade of light scarlet or flame per dozen, $\$ 4.00$ per 100. Postpaid.

Mrs. Frank Pendleton One of the finest varieties. The flowstrong straight spikes. In color a lovely salmon-pink with brilliant deep red blotches in the throat. Rivalling many of the finest orchids in its richness. $10 \mathrm{cts}$. each, 75 cts. per dozen, $\$ 5.00$ per 100 .

Orange Glory. This beautiful new Ruffled Glory has all the refined qualities of the original variety, Glory. The color range Glory. is a splendid shade of rosy orange. The flowers are exquisitely ruffled and are well placed on strong, stiff stems. 20 cts. each, $\$ 2.00$ per dozen, $\$ 12.00$ per 100 .

Prince of Wales. The flowers are large and well placed and the color is a most charming coral-pink. It is a sport $\$ 1.25$ per dozen, $\$ 8.00$ per 100 . \begin{tabular}{l} 
White Glory. A gorgeous pure white variety of the same type as Glory. The flowers are exquisitely shaped, splen- \\
\hline
\end{tabular}

Tait's Thorobred Mixture. This mixture of gladioli is composed of when massed produce a most gorgeous effect. 60 cts. per dozen, $\$ 4.00$ per 100 . Postpaid. 


\section{HERBACEOUS PAEONIES.}

\section{CHOICE VARIETIES}

The old-fashioned Paeony Officinalis, while still popular because of their early flowering have been eclipsed by the wonderful improved Herbaceous sorts introduced in recent years, and are the "Queen of Spring Flowers." They are too well known to require description, and their present popularity is due to the great improvement in them in recent years. They are most desirable for the lawn, flowerborder or shrubbery decoration. The handsome appearance of the plant, brilliant and striking effect of their massive, finely formed and richly colored flowers, and easy culture make it a most desirable flower. They can be planted either in fall or spring and do well in any good, rich garden soil.

An important point to observe in the planting of Peonies is not to plant too deep. The roots should be placed so that the crowns are covered with 2 inches of soil. Too deep planting is a frequent cause of shy flowering.

Pink Beauty. Large globular flowers of a delicate of the best pink paeonies. $\$ 1$ each, $\$ 10$ per doz.

Crimson Brilliant. Brilliant dazzling ruby red. $\$ 1$ each, \$10 per doz.

Edulis Superba, Mauve-pink; large and very handEdulis Superba. $55 \mathrm{cts}$. each, $\$ 7.50$ per doz Festiva Maxima. Handsome snow-white flowers in the center. $60 \mathrm{cts}$. each, $\$ 6$ per $\mathrm{doz}$.

Floral Treasure. Showy lilac-rose flowers. Very Unnamed Varieties - Pink, Red, White. 50 cts. each, \$5 per doz.

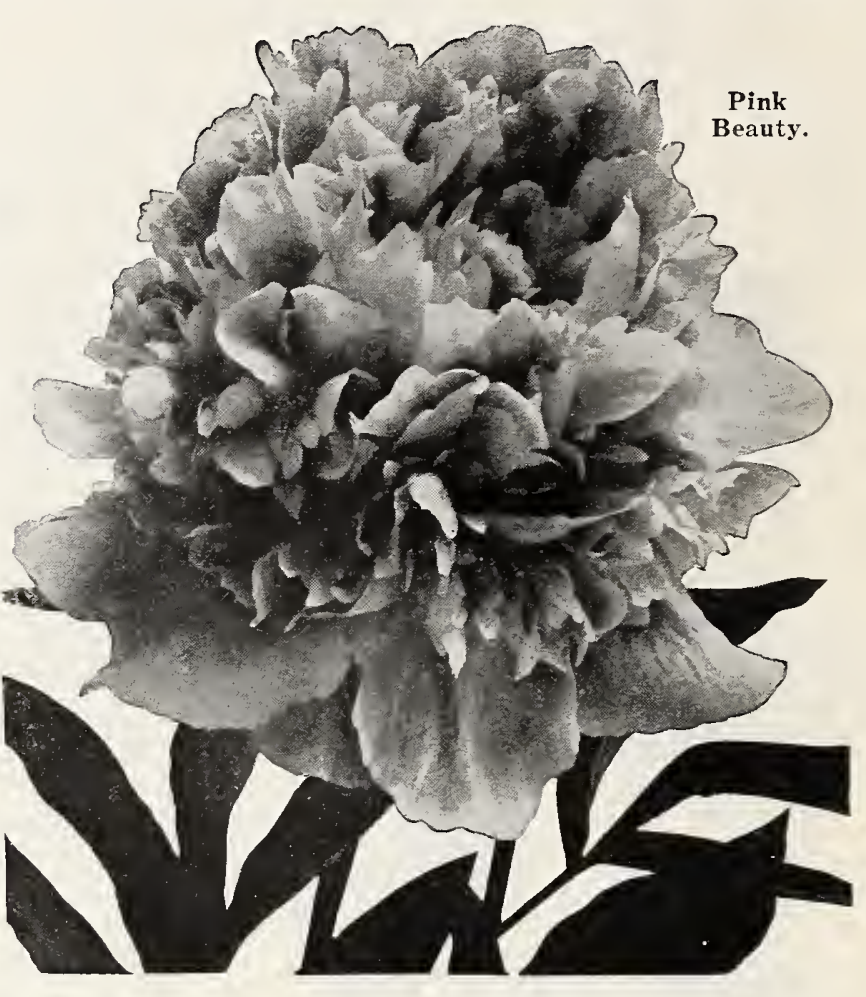

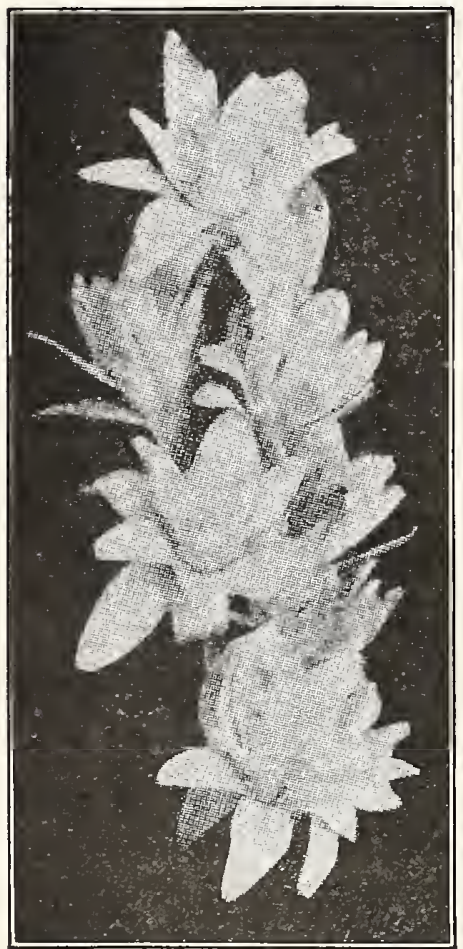

Double Pearl Tuberose.

\section{TUBEROSES}

One of the most delightfully fragrant and beautiful of summer flowering bulbs, and is so well-known that it needs no description.

CULTURE.-Tuberoses should be grown only in rich, well-drained soil, and where they can have abundance of sunshine. The bulbs should be set so that the tops will not be more than two inches under the surface of the ground, and as the flower stalks shoot up some light support should be provided to prevent damage by storms, and by skillful management a succession of flowers may be obtained nearly all the year around. For early flowers the bulbs can be started in February or March in the greenhouse or hotbed; and for a succession they can be planted at intervals as late as July. For flowering in the open, plant as soon as all danger of frost is over. Double Pearl. The flower spikes of this variety obtain a height of two feet or fectly double flowers that have the wax-like substance of a Camellia of glistening white. 60 cts. per dozen, $\$ 6.00$ per 100 . Postpaid.

Single or Orange Flowered. The spikes of this variety grow taller than to thirty single flowers which look very much like Orange Flowers. 60 cts., per dozen, $\$ 6.00$ per 100. Postpaid.

\section{ELEPHANT EARS}

(Caladium Esculentum)

Few foliage plants are so useful as the Caladium, and none require less attention after planting. Their magnificent leaves furnish the best possible background for grouping.

CULTURE.-For the best results, the bulbs should be planted in well drained rich soil. In dry weather the plants should be well watered. Planting is best done in April and May, the top of the bulb being set about five inches under the surface.

MAMМОTH BULBS............60 cts. each. $\$ 6.00$ per dozen. Postpaid.

LARGE BULBS ...............30 cts. each. \$3.00 per dozen. Postpaid.

SMILL BULBS..............20 cts. each. \$2.00 per dozen. Postpaid. 


\section{SPRAYERS}

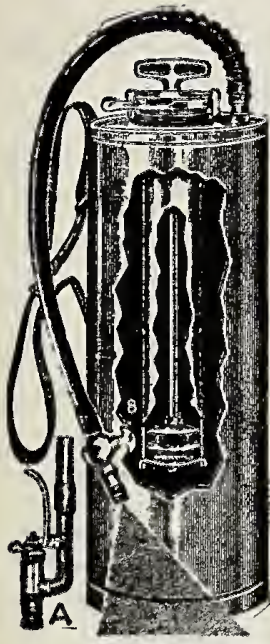

PATENTED.
At a popular price this is one of the strongest and most simple of Compressed Air Sprays. It is guaranteed against defect and to be satisfactory. Two or three pumpings will empty tank, and it is safe and efficient. Liquid capacity 4 gallons, pressure capacity 40 pounds.

No. 1-B Brass. Equipped with Brase and autopop attachment. \$9.75. Postpaid.

No. 1-D Galvanized Iron. Equipped with hose and auto-pop attachment. $\$ 7.25$. Postpaid.

\section{Auto Pop Nozzle Attach-} ment. Controls the flow instantly When auto pop attachment is purchased Auto Spray No. 1-B

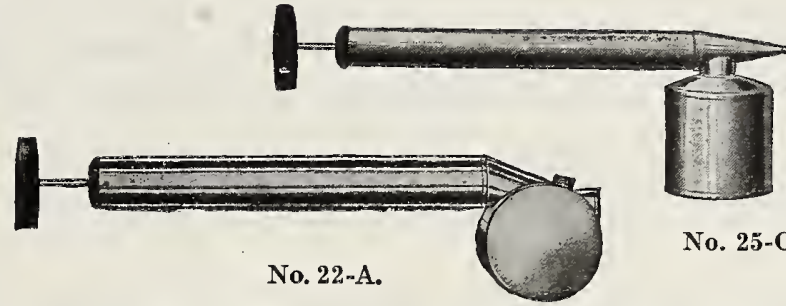

Compressed Air Sprayers. Capacity, about 1 family gardens we believe that these little sprayers will give satisfaction. We recommend the one with brass reservoir, as most spray solutions are exceedingly hard on tin or galvanized iron.

Auto Spray No. 25-C Tin pump and brass reserA voir. \$1.35. Postpaid.

Auto Spray No. 25-A Same as No. 25-C, but all Auto Spray No. $25-A$ tin. $\$ 1.00$. Postpaid. Auto Spray No. 22-A All tin. 65 ets. Postpaid.

\section{DUSTERS FOR APPLYING DRY INSECTICIDES}

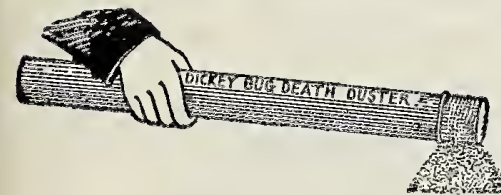

Dickey Bug Death Duster. For use in applying Bug ticide to small flower or vegetable gardens. It is a mighty handy thing to have around the house. Price $75 \mathrm{cts}$. Postpaid.

The Acre-an-Hour Sifter.

For farm use is ideal for applying Bug Death, or any dry insecticide. It is the very latest, a remarkably effective and distinctly economical method. Easy to operate and gives quick covering to all plants and vines requiring a top application. The price for this especially useful farm utensil is $\$ 1.10$. Postpaid.

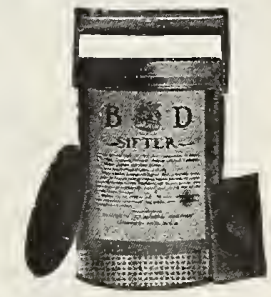

\section{INSECTICIDES AND REMEDIES FOR}

Poisonous Insecticides Cannot Be Mailed.

\section{PLANT DISEASES}

Poisonous Insecticides

Cannot Be Mailed.

The Prices of all Insecticides are net cash f. o. b. Norfolk and subject to change without notice.

Arsenate of Calcium, OR ARSENATE OF LIME effective insecticide for potatoes, cotton, tobacco, garden vegetables and seed fruits. Does not burn the foliage, sticks well to the leaf and being white shows where the poison has been applied. Do not use it for stone fruits like peach, plum, etc. $1 / 2$ lb. 20 cts., $1 \mathrm{lb} .35$ cts., 3 lbs. 75 cts. Express collect. Arsenate of Lead. The most popular remedy for use against all chewing bugs or insects that attack the foliage of plants or trees. It can be used both in dry and liquid form. Directions on each package. Powdered form: $1 / 2$ lb. 25 cts., 1 lb. 40 cts., 4 lbs. \$1.25. Express collect.

Black Leaf " 40 ." A concentrated solution of nicotine sulphate for spraying fruit trees or plants. It doft-bodied sucking insects. Especially good for all varieties of aphis, $\mathbf{1 - 0 z}$. bottles $35 \mathrm{cts}$., $1 / 2 \mathrm{lb}$. $\$ 1.25,2$ lbs. $\$ 3.50$. Express collect.

Bordeaux Mixture. (Powder.) The standard fungifor all fungus diseases, indispensable for the control of black rot in grapes, and blight in cucumbers, melons and potatoes. Used for a pple-scab, bitter-rot. $1 / 2$ lb. 20 cts., 1 lb. 35 cts., 5 lbs. \$1.50. Express collect.
Bug Death. This is a fungicide, insecticide and plant dry or in water. Lb. 25 cts., 3 lbs. 60 cts., 5 'lbs. 85 cts. Express collect.

Cut Worm Killer A preparation for the destruction Cout worms that will not poison chickens or birds; sure and effective. Lb. 35 cts. Express collect.

Lemon Oil. A safe and most effective insecticide. DeLitroys insects and bugs on leaves and roots of plants without injury to flower or foliage. Especially recommended for house plants. $1 / 2$ pint 30 cts., pint 50 cts. Express collect.

Lime Sulphur Powder. Where large quantities of powdered form is the most economical way to buy it. $\mathbf{L b}$. 50 cts., 5-lb. can $\$ 1.50$. Express collect.

Paris Green. A quick and effective poison used prinaris Green. cipally for destroying potato bugs. 1/4 lb. 15 cts., $1 / 2$ Ib. 25 cts., 1 lb. 45 cts. Express collect.

Slug Shot. A standard remedy for destroying insects or 5 lbs. 65 cts. Express collect.

Remember we deliver free at catalogue prices-except where noted. Write for special prices in large quantities. 


\section{HIGH-GR ADE FERTILIZERS}

The prices of Bone Meal, Guano, Sheep Manure and Lime are net cash f. o. b. Norfolk and subject to change without notice. Write for prices in large quantities.

Bone Meal (Raw). Analysis: Ammonia, 4 per cent.; Bone lical (RaW). phosphoric acid, 18.30 per cent. A standard fertilizer for all purposes-safe and effective. Quart 20 cts., 2 quarts 35 cts., 4 quarts 65 cts., 20 lbs. \$1.00, 100 lbs. $\$ 3.50,200$ lbs. $\$ 6.50$.

New Process 10 Per Cent. Analysis: Ammonia, phoric acid, 5 per cent. A special fertilizer largely used in the South as top dresser on peas, cabbage, kale, spinach and other early truck crops to hasten growth. Price: $100 \mathrm{lbs}$. $\$ 3.75,200$ lbs. $\$ 7.00$.

Peruvian Guano Substitute. Analysis: Ammonia phoric acid, 6 per cent.; potash, 5 per cent. Recommended as an all-round fertilizer for all vegetables, including potatoes, especially good for small gardens. Prices: 2 quarts 35 cts., 4 quarts 65 cts., 20 lbs. $\$ 1.00,100$ lbs. $\$ 3.00,200$ lbs. $\$ 5.50$.

\section{$7 \%$ Potato Guano. Analysis: Ammonia, 7 per cent.;} ash, 5 per cent. This brand is high in ammonia and will be found a splendid fertilizer for potatoes and other early vegetables; recommended where the earliest crops are desired. Prices: 100 lbs. $\$ 3.50,200$ lbs. $\$ 6.50$.
Wizard Brand Sheep Manure. A splendid allaround garden fertilizer, especially good for flowers and lawns. Attractively packed in 2, 5 and $10 \mathrm{lb}$. cartons and 25 and $100 \mathrm{lb}$. bags. Prices: 2 lbs. 20 cts., 5 lbs. 35 ets., 10 lbs. 55 cts., 25 lbs. $\$ 1.00$, 100 lbs. $\$ 3.25$.

Superior Plant Food. Universal in its year-'round those potted ferns, begonias or hyacinths of yours-and all summer on your outdoor garden, your bulb plants, roses, hardy shrubs, trees and lawn. Just dissolve a teaspoonful in the watering pot every time you sprinkle the garden. Clean and odorless. Price 25 cts., 50 cts. and $\$ 1.00$. Postpaid. The dollar size contains 600 treatments-enough for over a year.

Stim-U-Plant. Produces immediate growth in all kinds of plants. Can be used either in tablet or liquid form. Prices: Trial size, 10 tablets, 15 cts.; small size, 30 tablets, 25 ets. Large size, 100 tablets, 75 cts. Postpaid.

\section{Perfection Garden and Lawn Lime. Splendid to sweeten the soil and good for top-dressing lawns.}

\section{MOE'S POULTRY SUPPLIES}

\section{MOE'S Star Fountain and Feeder}
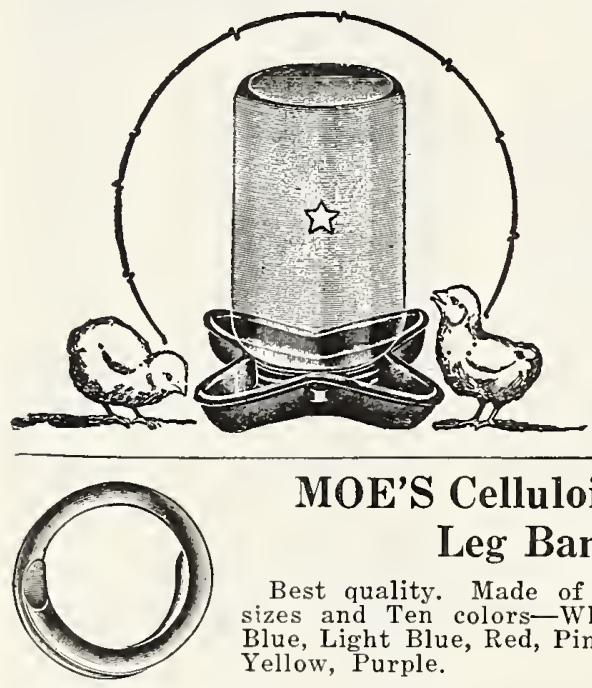

$\mathrm{Made}$ of a single piece of heavy metal. No solder, no seams, no loose parts. Suit able for feed as well as water. L i t t le chicks can not drown. Fits any Mason jar in 1 Pint, 1 Quart and $2 \mathrm{Qu}$ a $\mathrm{rt}$ sizes.

No. 32 (Glass jar not included). Each 15 cts.

\section{MOE'S Celluloid Colored Leg Bands}

Best quality. Made of Celluloid in Six sizes and Ten colors-White, Black, Dark Blue, Light Blue, Red, Pink, Garnet, Green, Yellow, Purple.

\section{SIZES}

Asiatic, American, Mediterranean, Bantam

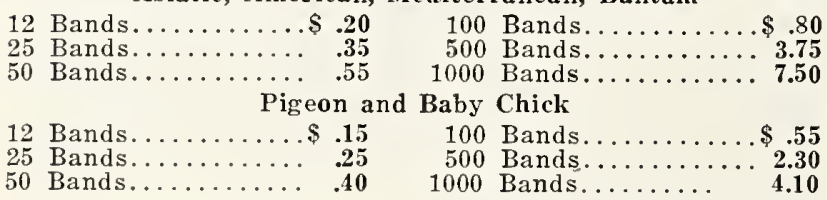

\section{MOE'S Baby Chick Feeders}

A great feed saver, and cain also be used for water or milk. Accurately stamped with dies. Top fits snugly, yet is easily taken off for filling and cleaning.

No. 11-Diam. 6 in., with 8 holes. Each 25c.

No. 12-Diam. 8 in. with 12 holes. Each 40 c.

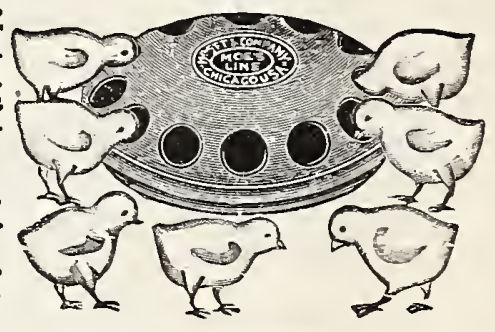

\section{MOE'S Double Feeding Troughs}

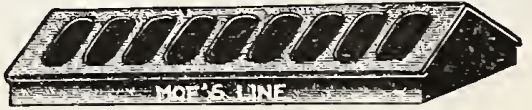

Double trough, with sliding top, easily filled and cleaned. Accurately staniped with dies. No rough edges.

No. 58 -Length 12 in ............................ $\$$

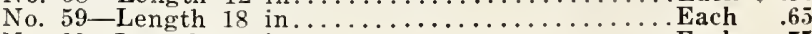

No. 60 -Length 24 in.................................

MOE'S Aluminum Leg Bands

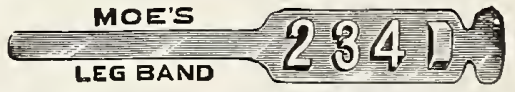

No. 130-Aluminum, with extra large raised numbers. Easy to read, adjustable for any size fowl. Quickly applied.

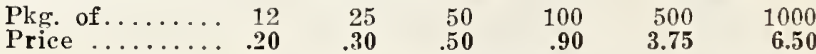

Remember we deliver free at catalogue prices-except where noted. Write for special prices in large quantities. 
Conkey

ONKEY'S ROUP REMEDY-Price

35 and 65 cts. Postpaid.

CONKEY'S ROUP PILLS-Price

30 and 55 cts. Postpaid.

CONKEY'S WHITE DIARRHOEA REMEDY-Price 35 and 65 cts. Postpaid.

CONKEY'S CHOLERA REMEDY-Price 30 and 55 cts. Postpaid. paid.

CONKEY'S LICE POWDER-Price 30 and 55 cts. Post-

CONKEY'S LICE LIQUID-Price: Quart 60 cts., 2 qts. 90 cts., gallon $\$ 1.50$. Express Collect.

CONKEY'S LICE FIX-Price 30 and 55 cts. Postpaid. paid.

CONKEY'S HEAD LICE OINTMENT-Price $30 \mathrm{cts}$. Post-

CONKEY'S POULTRY CONDITIONER-Price 30 and 55 cts. Postpaid.

CONKEY'S NOX-I-CIDE DIP AND DISINFECTANTPrice: Pint 50 cts., quart 80 cts., 2 quarts $\$ 1.25$. Express Collect.
CONKEY'S CANKER SPECIAL-Price 50

cents. Postpaid.

CONKEY'S LIMBERNECK REMEDY-

Price 55 cents. Postpaid.

CONKEY'S POULTRY WORM REMEDY-

Price 30 and 55 cents. Postpaid.

CONKEY'S SOREHEAD REMEDY-

Price 30 and 55 cents. Postpaid.

CONKEY'S SCALY LEG REMEDY-

Price 30 cents. Postpaid.

CONKEY'S BLACK HEAD REMEDY-Price 55 cents. Postpaid.

CONKEY'S GAPE REMEDY-Price 30 and 55 cents. Postpaid.

CONKEY'S FLY KNOCKER-Price: Quart 60 cts., halfgallon 90 cts. Express Collect.

\section{The Conkey Chain}

CONKEY'S BUTTERMILK STARTING FEED. CONKEY'S BUTTERMILK GROWING MASH. CONKEY'S BUTTERMILK LAYING MASH.

CONKEY'S CHICK GRAINS-Analysis: Protein 10.00, Fat 2.50, Fibre 5.00

The First Complete Line of Poultry Feeds Offered the Poultryman for Starting and Completing a Fowl's Ration. Conkey Originated Buttermilk Poultry Feeds and the "Unbroken Chain" System of Feeds. Don't break it-It's Wasteful and Dangerous?

CONKEY'S GROWLNG GRAINS-Analysis: Protein 10.50, Fat 3.00, Fibre 3.00.

CONKEY'S SCRATCH GRAINS-Analysis: Protein 9.75, Fat 1.75, Fibre 3.00, Nitrogen (Free Extract) 72.00 .

Don't Break the Conkey Chain of Buttermilk Feeds. Write or Ask For Prices.

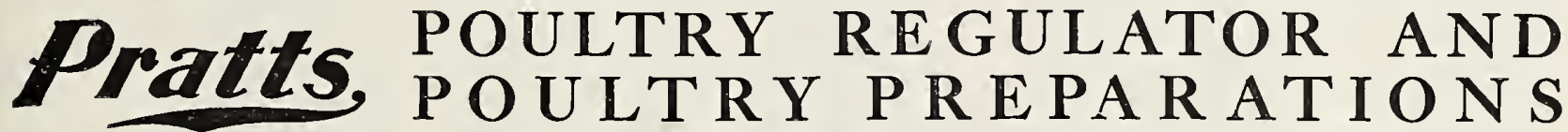

\section{For Health and Eggs PRATT'S Poultry Regulator}

has no equal. It is the world's original poultry regulator and has been the standard for over $\mathbf{5 0}$ years. It is a natural tonic supplying numerous health necessities required by heavy laying hens. Tones up system, regulates bowels, aids digestion, sharpens appetite, wards off disease and increases vitality. Use it the year round for breeders, layers and growing stock. 25 cts., 50 cts., $\$ 1.10$ packages. Express collect.
This original "baby food for baby chicks" has taken all the guess, worry and loss out of raising baby chicks. It is life insurance for chicks. Millions of pounds of PRATT'S Buttermilk Baby Chick Food

are used annually by successful poultry men all over the world. Use it for your chicks for the first month or six weeks and wateh results. Chicks grow strong, uniform, vigorous and sturdy. Pratt's is guaranteed to raise every livable chick. Equally good for young turkeys, guineas, ducks, pheasants and game birds. 35 and $65 \mathrm{cts}$. packages and $14,25,50$ and 100 lb. bags.

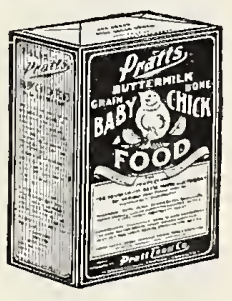

\section{Save Your Birds from Heavy Roup Losses} PRATT'S Roup Tablets

\section{(or Powder)}

Use it as a treatment or a preventive. A simple, powerful remedy with a long record of success in the treatment of colds, roup, diphtheria, catarrh, etc. Guaranteed to give satisfaction or your money back. 30 and 55 cts. packages. Postpaid.

\section{PRATT'S Powdered Lice Killer}

is powerful, economical, non-poisonous and non-irritating. For use on poultry, in dustbaths, nests, etc. Rids poultry of all ages, dogs, cats, horses, cattle, hogs and sheep of lice, ticks and other insect pests. Can also be used on vines, plants and flowers. In sifter top cans at 25 and 50 cts. Express Collect.

\section{PRATT'S Poultry Disinfectant}

insures poultry health. It is a cheap, powerful, non-poisonous disinfectant. Spray it about poultry houses, roosts, dropping boards, nests and wherever a strong disinfectant is needed. A deodorizer, germicide and liquid lice killer. Effective in the treatment of roup, cold and contagious diseases. Quart 55 cts., 1/2 gallon 95 cts., gallon $\$ 1.60$. Express Collect.
The most destructive of all chick diseases can be prevented by the use of

\section{PRATT'S White Diarrhea Tablets}

in the drinking water for the first couple of weeks. Proven by years of success, it will save you many dollars and chicks. Guaranteed. 30 and 55 cts. packages. Postpaid. 


\section{TERMS OF SALE, INSIDE FRONT COVER}

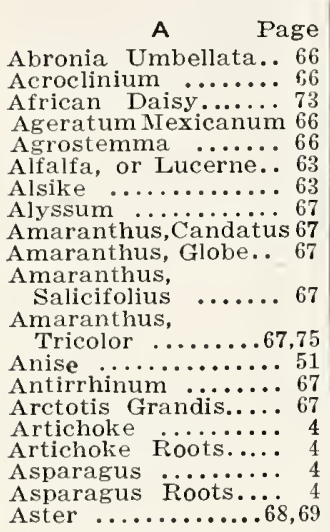

Baby's Breath....6.69,74 Bachelor Button...69,76 Balloon vine.......6.69 69 Balsam $\ldots \ldots \ldots \ldots \ldots$. 69 Balsam Pear......... 70 Barley Beanglish Broad Beans, Lima Bush. . Beans, Lima Pole

Beans, Snap Bush.. 5.6

Beans, Snap Pole....

Beans, Soja..........5 56

Beans, Soy $\ldots \ldots \ldots \ldots .56$

Beans, White or

Navy

Beet

Beet (Spinach Chard) 46 Beet, Stock or Mangel 10 Beet, Sugar......... 91 Bent Grass,

Rhode Island...... Bermuda Grass.....6.61 Bird Seed........... 51 Blanket Flower....70,7 Blue Grass, Kentucky Bokhara

Broccoli

Broom Corn..........

Erowallia $\ldots \ldots \ldots \ldots . . \cdots 7$

Brussels Sprouts.... 10
Buckwheat

Burnet ............... 10

Burr Clover.........6

C
Cabbage $\ldots \ldots . .12,13,14$

Cabbage, Chinese
(Pe-Tsai) ......14,38

Cabbage Peas......... 38

Caladium $\ldots \ldots \ldots \ldots .9969$

California Poppy..... 73

Canary

Canna Roots........

Cantaloupe ........28,29

Canterbury Bells....7 70

Caraway Climber...71,75

Cardoon....$\cdots \cdots \ldots$. 15

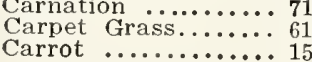

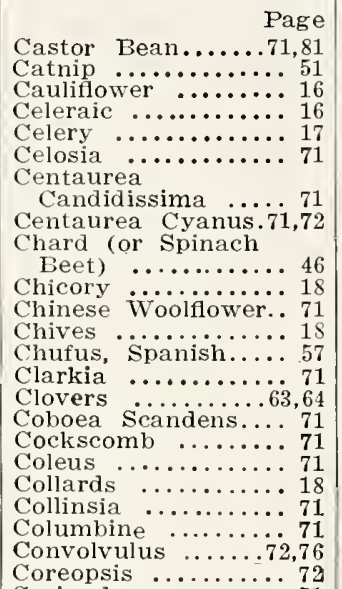

Coreopsis $\ldots \ldots \ldots \ldots \cdots 72$

Corn ……...18,19,20

Corn, Field.........52,53

Cornflower Salad............ 21

Cosmos $\ldots \ldots \ldots \ldots \ldots \ldots \ldots 72$

Cress water........

Crested Dog's Tail

Grass $\ldots \ldots \ldots \ldots 61$

Crimson Clover,

White Blooming....64 64

cucumber.

Cuttle Fish Bone.... 51

Cymbling vine........72,75

\section{Dahlia}

Dahlia Roots..... $9 \ddot{9} 90$

Daisy $\ldots . . . \cdots \cdots \cdots+72$

Dandelion ........... 232,75

Dianthus Barbatus.72,85

Dianthus-

Didiscus

Dill

Dimorphotheca $\ldots . . .7$

Diseases \& Remedies Inside Back Cover

Dish Cloth Gourd.

Dolichos Lablab...73.75

Dusters
Dusty

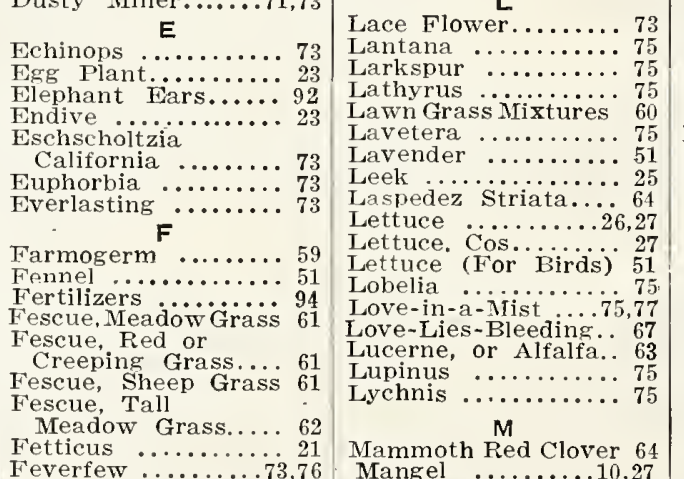

Gaillardia

Gladiolus ............

Heliotrope $\ldots \ldots \ldots 74$
Page

Finnochio

Flax .................

Floss Flower. .... 24

For-get-me-not .....73

Four o'Clock......73,76

Foxglove ............7 73

Garden Calendar.....70,74

Geranium $. . . \cdots \cdots \cdots, 74$

Gherkin .........22,24

Globe Thistle.......... 73

Godetia Gourds, o........ 74

Grain ........... 54

Guide for Sowing....

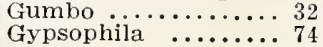

Hanover, ${ }^{H}{ }^{\circ}$

Plain Kale.

Hemp $\ldots \ldots \ldots \ldots \ldots 57$

Hemp (For Birds)... 51

Herd's, or

Red Top Grass.... 62

Holly for the Garden 1

Horehound $\ldots \ldots \ldots \ldots \ldots$. 51

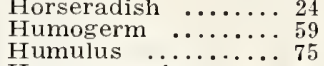

Hunnemannia $\ldots . . .75$

Ice Plant....

Inoculants

Insecticides.

Ipomoea Cardinalï 71,75

Ipomoea Mexicana $\mathbf{7 5 , 7 6}$

\section{pomoea}

Purpurea …72,75,76

Japan Clover

Japanese Hop........ 75

Joseph's Coat.......67,75

Kaffir Corn.

Kaffir Corn(for Birds) 51 Kale $\ldots \ldots \ldots \ldots \ldots \ldots 2,25$
Kochia $\ldots \ldots \ldots \ldots \ldots$

Kochia
Kohl Rabi.............

Petunia Cabbase..14.38

Phlox Drummondi... 89

Phlox Perennial..... 80

Pie Plant............ 43

Poppy ...........73,80

Potatoes ............. 40

Pot Marigold......... 51

Poultry Supplies...94,95

Pyrethrum ............ 80

\section{R}

Radish ........41,42,43 Randall Grass....... 62 Rape $\ldots \ldots \ldots \ldots \ldots \ldots . \ldots 58$ Reana Luxurians..... 58 Red Clover......... 64 Red Top, or Herd's

Rhodanthe

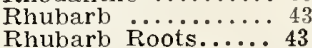

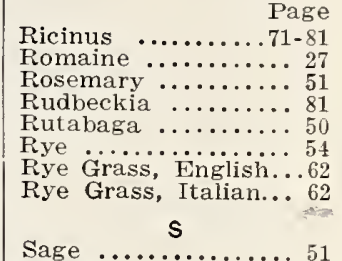

Salsify $\cdots \cdots \cdots \cdots \cdots$....... 51

Salvia .............. 81

Sanvitalia $\ldots \ldots . . .61$

Salpiglossis $\ldots \ldots \ldots$. 8

Scabious .......... 8

Scarlet Runner.....8 81

scarlet Sage........ 81

Schizanthus ....... 8

Senecio ........... 81

Sensitive Plant...... 81

Silene or Catchfly.... 82

Smilax ............ 82

Snow on the viountain 73

Sorghum ............ 5 Sorghum (For Birds) 51 Sorrel ............. 44

Soy Beans............ 56

Special Grass Mixture

for Golf Links....

Special Mixture for

Meadows \& Pastures 63

Spinach Beet.........44.45

Sprayers $\dot{S}_{\text {Sphing }} \ldots \ldots . . .93$ Inside Back Cover Spring Sprouts....25,46 Squash ...........45.46 Stock Beet............. 10 Stock Peas or

Soy Beans........ 56

Stocks $\ldots . . . \ldots \ldots \ldots .62$

Sugar Cane, or $\cdots \cdot . \cdots$

Sur cane.

Sorghum $\ldots \ldots \ldots$.... 55

Summer Savory.... 82

Sunflower

Sweet Alyssum.....6.67

Sweet Basil..........5

Sweet Clover .........

Sweet Marjoram ..... 51

Sweet Peas ....83,84,85

Sweet Peas, Hardy..75

Sweet Vernal Grass. 62

Sweet William ..... 85

Swiss Chard........ 46

Teosinte $\mathbf{T} \ldots \ldots \ldots 58$

Thunbergia $\ldots \ldots \ldots .86$

Timothy Gras..........

Tobacco ........... 55

Tomato

Tuberose ........999

Turnip ...........49,50

$\checkmark$

Vegetable Marrow... 46 Vegetable Oyster.... 44 Velvet Beans....... 56 Verbena ............ 86 Vinca $\ldots \ldots \ldots \ldots \ldots \ldots .68$

W

Whea

W.... 8 White Dutch clover. 64

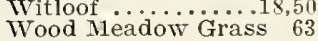
$z$

\section{Remember we deliver free at catalogue prices-except where noted. Write for special prices in large quantities.}




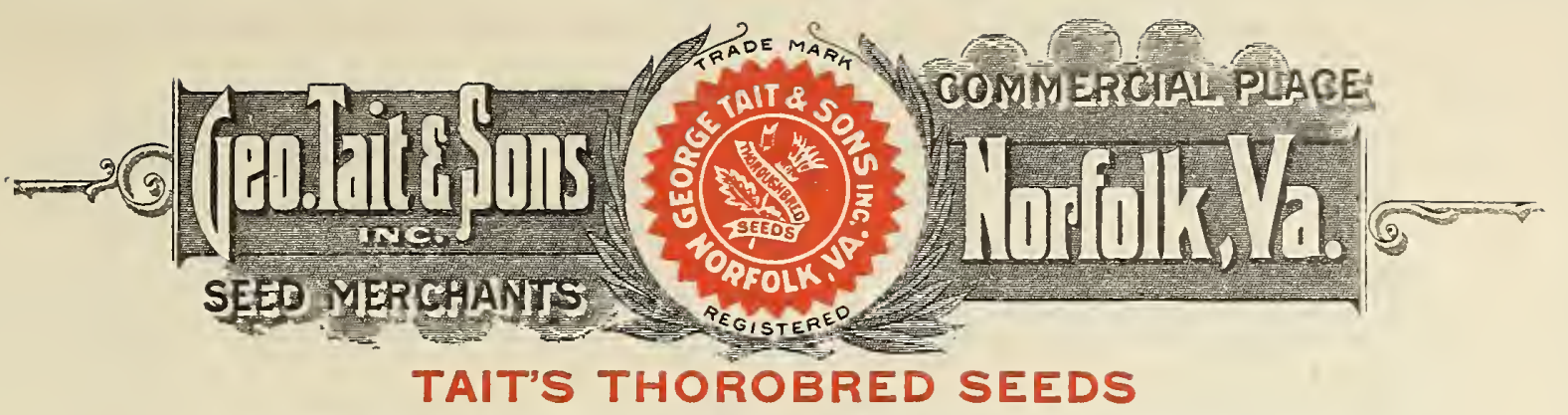

GEO. TAIT \& SONS, INc., gives no warranty, express or implied, as to deseription, quality, productiveness, or any other matter of any sceds, bulbs or plants it sells, and will not be responsible for the crop.

Dear Sirs:

Date.

Please forward the following order as per the terms of your catalogue for which find enclosed:

Name

(Write Plainly-Ladies will Plosse Put the Prefix Miss or Mrs.)

Post. Office

(writo Plainily)

Express Office

Shipping Point

County

$\{$ BOX No..................... Cash,

AMOUNT ENCLOSED

Loose Moner is Not Safo

Unless Sent BY Registered Mail

P. O. Order, $\$$

DATE RECEIVEO

If Tou Livo On \& Rural Fisll Routo, just give the letter and the money to the mail carrie and he will get the money order at the postoffic and mail it in the letter for you

Express Order, \$

DATE FILLED

Check or Draft, \$

R. F. D. No

Stamps,

$\$$

5 or 10 cent denominations.

PLEASE DO NOT WRITE

IN THIS SPACE

No.

State

Total,

$\$$

REMARKS

For Full Instructions About Orderlng Se0 Inside Cover Page in Our Catalogue.

NAMES OF SEEDS WANTED

PRICE 


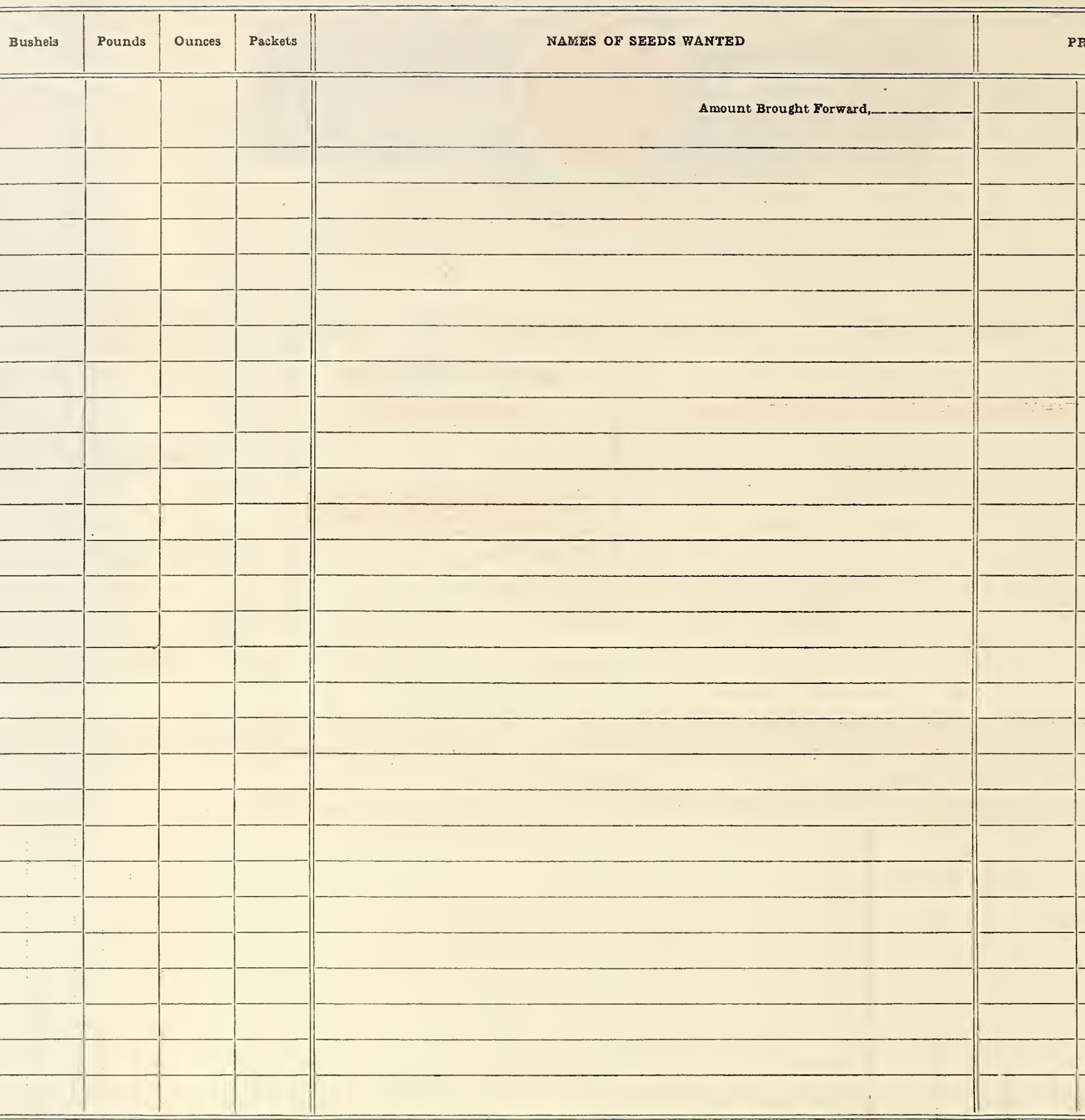

Wa Would Appreciato the INamos of a Fow of Your Friends Who Are Interested in Gardoning: We Wish To Eave Our Catalogue In Their Ziomes.

NAPRS

POST-OFFICE

STATE 


\section{SPRAYING SGHEDULE \\ To Control Diseases and Insect Pests}

For sprayers and dusters and spraying materials mentioned below, see page 93

We give below a list of Vegetables, Flowers and Fruits, the diseases which effect them and the insects that attack them.

\begin{tabular}{|c|c|c|c|c|c|c|}
\hline \multirow{2}{*}{$\begin{array}{l}\text { WHAT TO } \\
\text { SPRAY }\end{array}$} & \multirow{2}{*}{$\begin{array}{l}\text { DISEASE OR } \\
\text { INSECT }\end{array}$} & \multirow[b]{2}{*}{ WHAT TO USE } & \multicolumn{4}{|c|}{ WHEN TO SPRAY OR DUST } \\
\hline & & & $\begin{array}{l}\text { First Spraying } \\
\text { or Dusting }\end{array}$ & $\begin{array}{l}\text { Second Spraying } \\
\text { or Dusting }\end{array}$ & $\begin{array}{l}\text { Third Spraying } \\
\text { or Dusting }\end{array}$ & $\begin{array}{l}\text { Fourth Spraying } \\
\text { or Dusting }\end{array}$ \\
\hline Asparagus & $\begin{array}{l}\text { Beetle } \\
\text { Rust }\end{array}$ & $\begin{array}{l}\text { Arsellate of Lead or Paris lireen } \\
\text { Bordeaux Mixture }\end{array}$ & $\begin{array}{l}\text { As pests appear } \\
\text { After cutting }\end{array}$ & $\begin{array}{l}\text { Same as first } \\
10 \text { days later }\end{array}$ & $\begin{array}{l}\text { Same as first } \\
10 \text { days later }\end{array}$ & $\begin{array}{l}\text { Same as first } \\
10 \text { days later }\end{array}$ \\
\hline Beans & $\begin{array}{l}\text { Rust and blight } \\
\text { Leaf beetle } \\
\text { Aphis or louse }\end{array}$ & $\begin{array}{l}\text { Bordeaux Mixture } \\
\text { Arsenate of Lead or Bug Death } \\
\text { Tobacco Soap, Black Leaf } 40\end{array}$ & $\begin{array}{l}\text { Fumigate seed } \\
\text { on } 3 \text { inch plants } \\
\text { ds pests appear }\end{array}$ & $\begin{array}{l}10 \text { days later } \\
\text { Same as first }\end{array}$ & $\begin{array}{l}10 \text { days later } \\
\text { Same as first }\end{array}$ & Same as first \\
\hline $\begin{array}{l}\text { Beets } \\
\text { Swiss Chard, } \\
\text { and Mangels }\end{array}$ & $\begin{array}{l}\text { Leaf spot } \\
\text { Blister Beetle or } \\
\text { Aphis or louse } \\
\end{array}$ & $\begin{array}{l}\text { Bordeaux } \\
\text { Tobaceo Soap or Black Leaf } 40\end{array}$ & $\begin{array}{l}\text { As spots appear } \\
\text { When they } \\
\text { appear }\end{array}$ & $\begin{array}{c}2 \text { to } 3 \text { weeks later } \\
\text { Same as first }\end{array}$ & $\begin{array}{l}2 \text { to } 3 \text { weeks later } \\
\text { Same as first }\end{array}$ & $\begin{array}{l}3 \text { weeks later } \\
\text { Same as first }\end{array}$ \\
\hline $\begin{array}{l}\text { Bloccoli. } \\
\text { Brussels Sprouts } \\
\text { Cabbage and } \\
\text { Gauliflower } \\
\end{array}$ & \begin{tabular}{|l|} 
Worms \\
Root maggot \\
Cut worms
\end{tabular} & $\begin{array}{l}\text { Tobaceo Soap, Bug Death, } \\
\text { slug shot } \\
\text { Mag-o-tite } \\
\text { Cut Worm Killer }\end{array}$ & $\begin{array}{l}\text { When they } \\
\text { appear } \\
\text { As they appear } \\
\text { As they appear }\end{array}$ & $\begin{array}{l}\text { Same as first } \\
\text { Same as first } \\
\text { Same as first }\end{array}$ & $\begin{array}{l}\text { Same as first } \\
\text { Same as first } \\
\text { Same as first }\end{array}$ & $\begin{array}{l}\text { Same as first } \\
\text { Same as first } \\
\text { Same as first }\end{array}$ \\
\hline Celery & Blight or rust & Bordeaux Mixture & Cover the leaves & As set in garden & 10 to 15 days later & 10 to 15 days later \\
\hline$\overline{\text { Corn }}$ & $\begin{array}{l}\text { Smut } \\
\text { Cut worms }\end{array}$ & $\begin{array}{l}\text { Cut off and burn smut swellings } \\
\text { Cut Worm Filler }\end{array}$ & As they appear & Same as first & Same as first & Same as first \\
\hline $\begin{array}{l}\text { Cucumber, } \\
\text { Muskmelon, } \\
\text { Watermelon } \\
\text { Gourds, Pumpkin } \\
\quad \text { and Squash }\end{array}$ & $\begin{array}{l}\text { Blight, mildew } \\
\text { Striped beetle or } \\
\text { Squash bug } \\
\text { Vine borer } \\
\text { Aphis or louse }\end{array}$ & $\begin{array}{l}\text { Bordeaux Mixture } \\
\text { Tobaceo Soap, Slug Shot, Bug } \\
\text { Death } \\
\text { Bordo-Lead } \\
\text { Slug Shot or Bug Death } \\
\text { or Blick Leaf } 40 \text {, Tobaceo Soap }\end{array}$ & $\begin{array}{c}\text { As plants form rine } \\
\text { When they } \\
\text { appear } \\
\text { On young plants } \\
\text { When they appear. }\end{array}$ & $\begin{array}{l}2 \text { weeks later } \\
5 \text { days later } \\
2 \text { weeks later } \\
\text { Same as first }\end{array}$ & $\begin{array}{l}2 \text { weeks later } \\
5 \text { days later } \\
2 \text { weeks later } \\
\text { Same as first }\end{array}$ & $\begin{array}{l}2 \text { weeks later } \\
5 \text { days later if } \\
\text { needed } \\
2 \text { weeks later } \\
\text { Same as first }\end{array}$ \\
\hline$\overline{\text { Egg Plant }}$ & $\begin{array}{l}\text { Leaf spot, } \\
\text { Blight } \\
\text { Potato bugs }\end{array}$ & $\begin{array}{l}\text { Bordeaux Mixture, Paris Green, } \\
\text { Arsenate Lead, Bordo Lead, Bug } \\
\text { Death or slug Shot } \\
\end{array}$ & $\begin{array}{c}\text { As plants are set } \\
\text { When they appear }\end{array}$ & $\begin{array}{l}10 \text { days later } \\
\text { Same as first }\end{array}$ & $\begin{array}{l}10 \text { days later } \\
\text { Same as first }\end{array}$ & $\begin{array}{l}10 \text { days later if } \\
\text { needed Same as first }\end{array}$ \\
\hline Gardens, Lawns & Ants & Bug Deatli & As they appear & Same as first & Same as first & Same as first \\
\hline Lettuce & $\begin{array}{l}\text { Aphis or louse } \\
\text { Worms }\end{array}$ & $\begin{array}{l}\text { Black Leaf } 40 \\
\text { Bug Death, Slug Shot }\end{array}$ & $\begin{array}{l}\text { As they appear } \\
\text { As they appear }\end{array}$ & $\begin{array}{l}\text { Same as first } \\
\text { Same as first }\end{array}$ & $\begin{array}{l}\text { Same as first } \\
\text { Same as first }\end{array}$ & $\begin{array}{l}\text { Same as first } \\
\text { Same as first }\end{array}$ \\
\hline$\overline{\text { Onions }}$ & $\begin{array}{l}\text { Thrip (small } \\
\text { suching insects) } \\
\text { Maggot }\end{array}$ & $\begin{array}{l}\text { Black Leaf } 40 \text {, Tobacco Soap or } \\
\text { Bug Death Aphis } \\
\text { Tobacco Soap, Mag-o-tite }\end{array}$ & $\begin{array}{c}\text { When they appear } \\
\text { As they appear }\end{array}$ & $\begin{array}{l}\text { Same as first } \\
\text { Same as first }\end{array}$ & $\begin{array}{l}\text { Same as first } \\
\text { Same as first }\end{array}$ & $\begin{array}{l}\text { Same as first } \\
\text { Same as first }\end{array}$ \\
\hline Peas & $\begin{array}{l}\text { Mildew } \\
\text { Aphis or louse }\end{array}$ & $\begin{array}{l}\text { Bordeaux Mixture } \\
\text { Tobacco Soap, Black Leaf } 40\end{array}$ & $\begin{array}{l}\text { When it appears } \\
\text { When they appear } \\
\end{array}$ & $\begin{array}{l}2 \text { weeks later } \\
\text { Same as first }\end{array}$ & $\begin{array}{l}2 \text { weeks later } \\
\text { Same as first }\end{array}$ & $\begin{array}{c}2 \text { weeks later if } \\
\text { needed Same as first }\end{array}$ \\
\hline Fotatoes & $\begin{array}{l}\text { Blight } \\
\text { Potato bugs or } \\
\text { Blister Bug }\end{array}$ & $\begin{array}{l}\text { Bordea ux Mixture or Bordo Lead, } \\
\text { Paris Green, Arsenate Lead, Bug } \\
\text { Deatlh Slug Shot }\end{array}$ & $\begin{array}{c}\text { On } 6 \text { inch plants } \\
\text { When tley appear }\end{array}$ & $\begin{array}{l}2 \text { weeks later } \\
\text { Same as first }\end{array}$ & $\begin{array}{l}2 \text { weeks later } \\
\text { Same as first }\end{array}$ & $\begin{array}{l}2 \text { weeks later } \\
\text { Same as first }\end{array}$ \\
\hline Radish & Maggot & Tobacco Soap, Mag-o- ite & As they appear & Same as first & Same as first & Same as first \\
\hline Tomatoes & $\begin{array}{l}\text { Leaf spot or } \\
\text { blight, Potato } \\
\text { bug or Worms } \\
\text { Cut Worms } \\
\end{array}$ & $\begin{array}{l}\text { Bordeaux Mixture } \\
\text { Bordo Lead, Bug Death, Slug } \\
\text { Shot } \\
\text { Cut Worm Killer } \\
\end{array}$ & $\begin{array}{c}\text { On young plants } \\
\text { When they appear } \\
\text { As they appear }\end{array}$ & $\begin{array}{l}3 \text { weeks later } \\
\text { Same as first } \\
\text { Same as first }\end{array}$ & $\begin{array}{l}3 \text { weeks later } \\
\text { Same as first } \\
\text { Same as fir'st }\end{array}$ & $\begin{array}{l}3 \text { weeks later } \\
\text { Same as first } \\
\text { Same as first }\end{array}$ \\
\hline $\begin{array}{l}\text { Turnips and } \\
\text { Ruta Baga } \\
\end{array}$ & $\begin{array}{l}\text { Flea beetle } \\
\text { Maggot }\end{array}$ & $\begin{array}{l}\text { Bug Death, Slug Shot } \\
\text { Tobaceo Soap, Black Leaf } 40\end{array}$ & $\begin{array}{l}\text { As they appear } \\
\text { As they appear }\end{array}$ & $\begin{array}{l}\text { Same as first } \\
\text { Same as first }\end{array}$ & $\begin{array}{l}\text { Same as first } \\
\text { Salne as first }\end{array}$ & $\begin{array}{l}\text { Same as first } \\
\text { Same as first }\end{array}$ \\
\hline Asters & $\begin{array}{l}\text { Aphis or louse } \\
\text { Blister beetle }\end{array}$ & Black Leaf 40 , Tobaceo Soap & When they appear & Same as first & Same as first & Same as first \\
\hline $\begin{array}{l}\text { Carnation and } \\
\text { Chrysanthemum }\end{array}$ & $\begin{array}{l}\text { Aphis or louse } \\
\text { Leaf spot }\end{array}$ & $\begin{array}{l}\text { Black Leaf } 40, \text { Tobaceo Soap } \\
\text { Bordeaux Mixture }\end{array}$ & $\begin{array}{c}\text { When they appear } \\
\text { As spots appear }\end{array}$ & $\begin{array}{l}\text { Same as first } \\
2 \text { weeks later }\end{array}$ & $\begin{array}{l}\text { Same as first } \\
2 \text { weeks later }\end{array}$ & $\begin{array}{l}\text { Same as first } \\
2 \text { weeks later }\end{array}$ \\
\hline Dahlias & Blight & Bordeaux Mixture & As spots appear & 2 weeks later & 2 weeks later & 2 weeks later \\
\hline $\begin{array}{l}\text { Ferns. Pansy \& } \\
\text { Nasturtiums } \\
\end{array}$ & Aphis or louse & Black Leaf 40 , Tobacco Soap & When they appear & Same as first & Same as first & Same as first \\
\hline Roses & $\begin{array}{l}\text { Aphis or louse } \\
\text { Worm and slug } \\
\end{array}$ & Black Leaf 40, Tobacco Soap & When they appear & Same as first & Same as first & Same as first \\
\hline Sweet Peas & Aphis or louse & Black Leaf 40, Tobacco Soap & When they appear & Same as first & Same as first & Same as first \\
\hline Apples & $\begin{array}{l}\text { Black rot, bloteh } \\
\text { and fruit spot } \\
\text { Canker worm } \\
\text { Codling moth } \\
\text { Scab } \\
\text { San Jose scale } \\
\end{array}$ & $\begin{array}{l}\text { Bordeaux Mixture } \\
\text { Arsenate of Lead } \\
\text { Bordo Lead } \\
\text { Bordeaux Mixture } \\
\text { Lime Sulphur of Scalicide }\end{array}$ & $\begin{array}{l}\text { First appearance } \\
\text { rot about July } 1 \\
\text { As they appear } \\
\text { As blossoms fall } \\
\text { Before blossoming } \\
\text { Late fall, winter } \\
\end{array}$ & \begin{tabular}{|}
1 or 2 weeks later \\
2 to 3 days later \\
$i$ to 10 days later \\
ffter blossoms drop \\
or early spring \\
\end{tabular} & $\begin{array}{l}2 \text { weeks later } \\
\text { Same as seeond } \\
30 \text { days later } \\
\text { T to } 10 \text { days later }\end{array}$ & $\begin{array}{l}14 \text { days later } \\
\text { Rarely needed }\end{array}$ \\
\hline $\begin{array}{l}\text { Dewberry } \\
\text { Blackberry } \\
\text { Raspberry }\end{array}$ & $\begin{array}{l}\text { Cane blight } \\
\text { Leaf spo: }\end{array}$ & $\begin{array}{l}\text { Bordeaux Mixture } \\
\text { Bordeaux Mixture }\end{array}$ & $\begin{array}{c}\text { Before leares oper } \\
\text { When leares are } \\
\text { half grown } \\
\end{array}$ & $\begin{array}{c}\text { On young canes } \\
2 \text { weeks later } \\
\end{array}$ & $\begin{array}{c}1 \text { week later } \\
3 \text { weeks later }\end{array}$ & \\
\hline Cherry & $\begin{array}{l}\text { Leaf spot } \\
\text { Rot } \\
\text { Curculio }\end{array}$ & $\begin{array}{l}\text { Bordeaux Mixture } \\
\text { Bordeaux Mixture } \\
\text { Arsenate of Lead }\end{array}$ & $\begin{array}{l}\text { Leaves unfolding } \\
\text { Before blossoming } \\
\text { Before blossoming }\end{array}$ & \begin{tabular}{|c|}
2 weeks later \\
After blossoms drop \\
As blossoms dry up
\end{tabular} & $\begin{array}{c}2 \text { to } 3 \text { weeks later } \\
2 \text { weeks later on fruit } \\
1 \text { week later } \\
\end{array}$ & 2 weeks later \\
\hline $\begin{array}{l}\text { Currant and } \\
\text { Gooseberry }\end{array}$ & $\begin{array}{l}\text { Worm } \\
\text { Leaf spot,Mild'w } \\
\text { San Jose Scale } \\
\end{array}$ & $\begin{array}{l}\text { Tobacco Soap } \\
\text { Bordeaux Mixture } \\
\text { Lime Sulphur or Scalicide }\end{array}$ & $\begin{array}{l}\text { As they appear } \\
\text { Leaves unfolding } \\
\text { Late fall, winter }\end{array}$ & $\begin{array}{l}3 \text { or } 4 \text { days later } \\
2 \text { weeks later } \\
\text { or early spring }\end{array}$ & $\begin{array}{l}\text { Same as first } \\
2 \text { weeks later }\end{array}$ & $\begin{array}{l}\text { Same as first } \\
2 \text { to } 3 \text { weeks later }\end{array}$ \\
\hline Grape & $\begin{array}{l}\text { Rose bug } \\
\text { Black rot } \\
\end{array}$ & $\begin{array}{l}\text { Arsenate of Lead or Tobacco Soalp } \\
\text { Bordeaux Mixture }\end{array}$ & $\begin{array}{c}\text { As they appear } \\
\text { Before blossoming }\end{array}$ & $\begin{array}{c}1 \text { week later } \\
\text { After fruit llas set }\end{array}$ & F to 8 dars later & 7 or 8 days later \\
\hline Peach & $\begin{array}{l}\text { Leaf eurl } \\
\text { Brown Rot } \\
\text { San Jose Scale }\end{array}$ & $\begin{array}{l}\text { Bordeaux Mixture or Lime Sulphur } \\
\text { Bordeaux Mixture or Lime Su'phur } \\
\text { Lime Sulphur or Scalicide }\end{array}$ & $\begin{array}{l}\text { Fall, early spring } \\
\text { Shucks shedding } \\
\text { Late fall, winter }\end{array}$ & $\begin{array}{c}\text { As buds open } \\
2 \text { or } 3 \text { weeks later } \\
\text { or early spring } \\
\end{array}$ & $\begin{array}{l}\text { After calyx drops } \\
4 \text { weeks before } \\
\text { fruit is ripe }\end{array}$ & \\
\hline$\overline{\text { Pear }}$ & $\begin{array}{l}\text { Slug } \\
\text { San Jose Scale }\end{array}$ & $\begin{array}{l}\text { Arsenate of Lead or Bug Death } \\
\text { Lime Sulphur or Scalicide }\end{array}$ & $\begin{array}{l}\text { As they appear } \\
\text { Late fall, winter }\end{array}$ & $\begin{array}{l}\text { Same as first } \\
\text { or early spring }\end{array}$ & Same as first & Same as first \\
\hline Plum & $\begin{array}{l}\text { Curculio } \\
\text { Brown rot } \\
\text { San Iose Scale } \\
\end{array}$ & $\begin{array}{l}\text { Arsenate of Lead } \\
\text { Bordeaux Mixture or Lime Sulphur } \\
\text { Lime Sulphur or Scalicide } \\
\end{array}$ & $\begin{array}{l}\text { Before buds open } \\
\text { Shucks shedding } \\
\text { Late fall, winter }\end{array}$ & $\begin{array}{l}\text { At fall of blossom } \\
2 \text { or } 3 \text { weeks later } \\
\text { or early spring } \\
\end{array}$ & $\begin{array}{l}\text { I to } 10 \text { days later } \\
4 \text { weeks before } \\
\text { fruit is ripe }\end{array}$ & \\
\hline Strawberry & Leaf spot & Bordeaux Mixture & Before blossoming & 10 to 12 days later & & \\
\hline
\end{tabular}




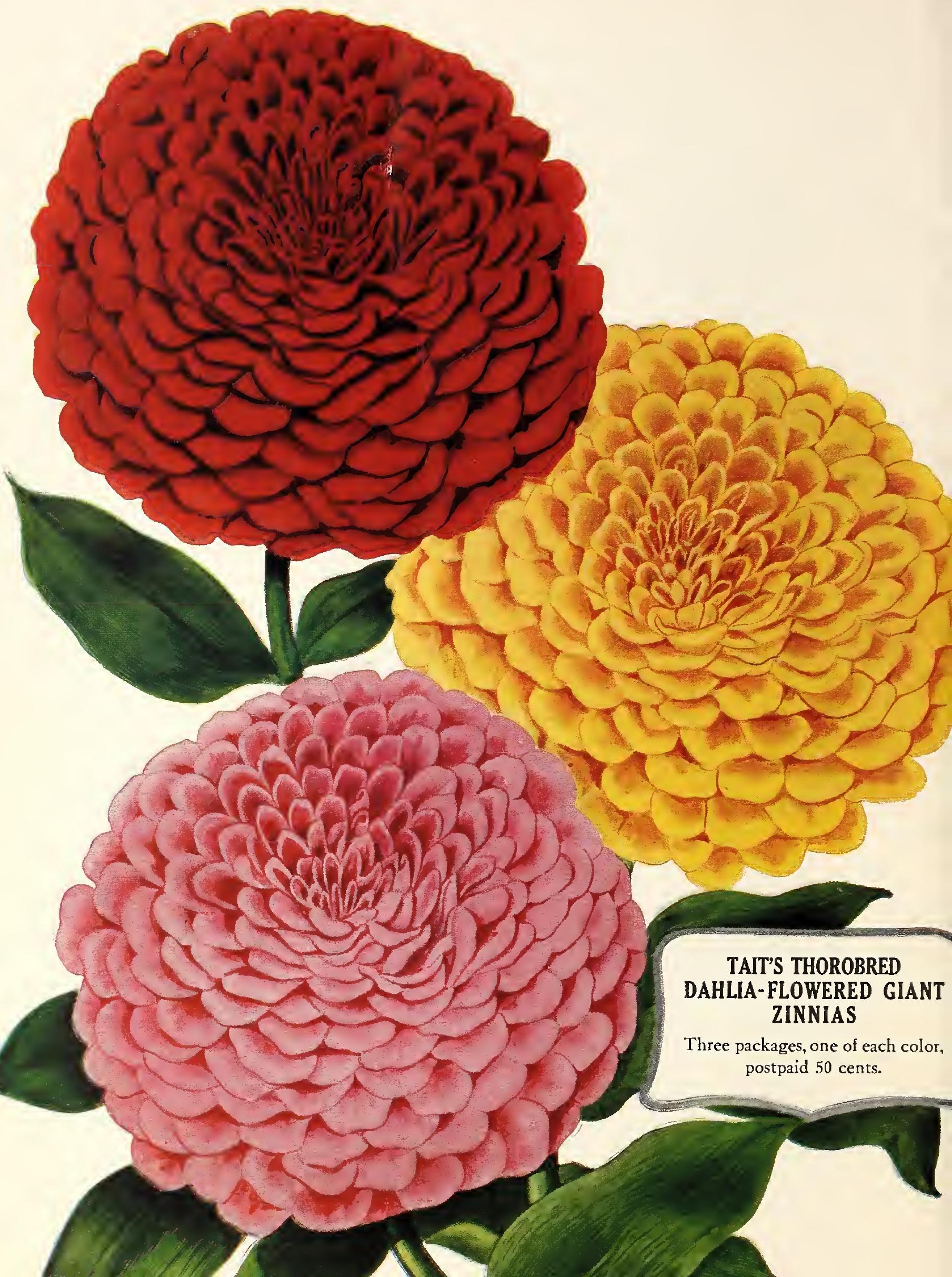

